Copyright

by

Philip Thomas Roundy

2013 
The Dissertation Committee for Philip Thomas Roundy certifies that this is the approved version of the following dissertation:

The Stories of Social Entrepreneurship: Narrative Discourse and Social Enterprise Resource Acquisition

Committee:

Melissa E. Graebner, Supervisor

John S. Butler

Kimberly D. Elsbach

Luis L. Martins

Violina P. Rindova 
The Stories of Social Entrepreneurship:

Narrative Discourse and Social Enterprise Resource Acquisition

by

Philip Thomas Roundy, B.A.; M.A.; M.S.; M.S. Man

\author{
Dissertation \\ Presented to the Faculty of the Graduate School of \\ The University of Texas at Austin \\ in Partial Fulfillment \\ of the Requirements \\ for the Degree of \\ Doctor of Philosophy
}

The University of Texas at Austin

August 2013 


\section{Dedication}

To Angela, my parents, and God 


\section{Acknowledgements}

Officially this dissertation bears only my name; however, it would not have come to fruition without the help of several people. First, I am indebted to my entire dissertation committee for their assistance during this process. John Butler, Luis Martins, and Violina Rindova provided helpful feedback and support. Kim Elsbach went above and beyond what is expected of an outside committee member with her detailed comments and suggestions. My deepest gratitude, however, goes to my advisor and mentor, Melissa Graebner. Melissa has had the patience to help turn a "hard-boiled" economist into a management researcher. She has also been an endless supply of encouragement and advice on all matters related to my career. Moreover, she has displayed a deep concern for both my professional career and personal well-being, I have realized this is a rare trait in an advisor and one for which I have incredible respect. Without her help my Ph.D. journey would not have been nearly as smooth.

I also have the utmost appreciation for the guidance, mentorship, and friendship of Jim Fredrickson and Dave Harrison. Jim has not only shared his passion for understanding how executives think but he has also spent countless hours reading my work, providing advice, and helping me to hone my understanding of the subject. Likewise, from the day I met Dave he has been available to help me with any and every question I've had. I am in awe of his dedication to Ph.D. students. Indeed, his unselfishness with his time and his devotion to both students and faculty colleagues will serve as a model for me throughout my career. Moreover, I know I'll look back on the times we spent hammering on ideas and debating the directions of manuscripts as some of the most intellectually stimulating experiences of my graduate training. 
I also thank my fellow Ph.D. students - past and present - for their friendship and support. I doubt I would have survived the program if not for the help of more "senior" students including Ye Dai, Bruce Rudy, David Chandler, Matt Theeke, Jonathan Sims, and Jeff Wehrung. Furthermore, because of the intense demands on our time, it was very difficult to have friends outside of the program. Thus it was a blessing to be surrounded by individuals like Mark Bayer, Bruce Greenbaum, Shannon Rariden, Julie Sharek, Taeya Howell, Christina Kypraniou, and Suho Han who were good colleagues but became great friends.

Also, I offer a heartfelt thank you to all of the social entrepreneurs who volunteered their time as participants in this research. It is without any amount of hyperbole or exaggeration that I say my interactions with them have been the high point of my professional career. They are changing the world. I merely chronicle their remarkable efforts.

I offer the deepest of thanks to my parents for their unconditional love, unwavering support, and intense faith in me. Their confidence has inspired me to believe I can face any challenge. They have never desired anything other than my happiness. They have done everything humanly possible to provide it. And, most importantly, they have always made it clear that as long as I pursue what is right they will support me, without question, in any decision - no matter how unpopular.

Words cannot fully capture the gratitude I have for my wife, Angela. Throughout my time in graduate school she has been an unfailing source of encouragement, humor, and most importantly, love. She has made an untold number of sacrifices so that I may be able to finish this dissertation and my Ph.D. Although the journey has been long and, at times, lonely, she has never complained. Moreover, her intellect and influence is present on virtually every page of this document. Every significant idea contained herein was 
refined and improved through our conversations - usually during a long walk. In fact, her influence on this work has been so great it is unfair that dissertations cannot have coauthors. Luckily, however, the "story" of life has no such rule.

Finally, the ideas contained in this dissertation would never have existed were it not for C.S. Lewis. His life demonstrates that one can be both a scholar and a lover of narratives. His writings reveal the immense power of stories and faith - and the amazing relationship between the two. 'Further up and further in ...' Indeed. 


\title{
The Stories of Social Entrepreneurship: Narrative Discourse and Social Enterprise Resource Acquisition
}

\author{
Philip Thomas Roundy, Ph.D. \\ The University of Texas at Austin, 2013
}

Supervisor: Melissa E. Graebner

Social entrepreneurship is a phenomenon of increasing economic and cultural importance. A key challenge for social enterprises is resource acquisition. However, how social entrepreneurs acquire the resources needed to grow their ventures is not clear. Moreover, social enterprises differ from traditional ventures in several key ways which suggest that research developed from studying traditional entrepreneurs does not fully apply to social entrepreneurs.

The focus of this dissertation is how social entrepreneurs use narratives to gather resources. This topic is examined using a multi-study, inductive, theory-building design based on 121 interviews, observation, and archival data. In Study 1, I interview 75 entrepreneurs, investors, and ancillary participants in the social enterprise sector. In Study 2, I construct case studies of eight technology-focused social ventures.

The result is a framework explaining how differences in entrepreneurs' narrative tactics and characteristics are associated with differences in their resource acquisition success. Specifically, from Study 1 I develop a typology of social enterprise narratives, identify three narrative-types (personal, social-good, and business), and show that they possess unique elements. Findings from Study 2 demonstrate that the three narrative- 
types serve as the building blocks for communication with external stakeholders, particularly investors and the media. I find that successful social entrepreneurs used narratives to engage in two tactics - tailoring and linking - and constructed narratives with a unique characteristic: multiplexity. These findings contribute to three literatures that formed the basis of the study - social entrepreneurship, entrepreneurial resource acquisition, and organizational narrative theory - and have implications for work on competing institutional logics and emotion in stakeholder evaluations. 


\section{Table of Contents}

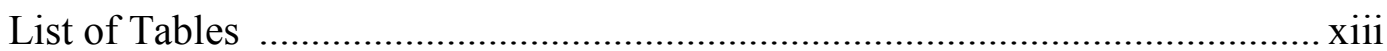

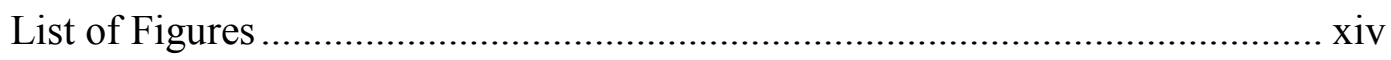

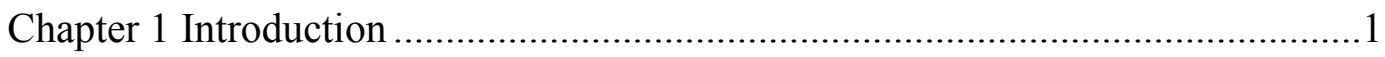

Chapter 2 A Review of the Literature on Social Entrepreneurship .......................10

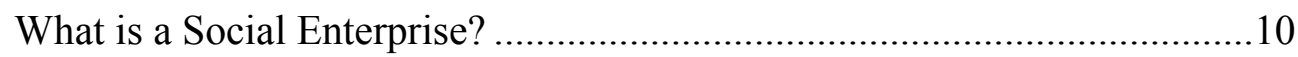

Social Enterprise and Related Organizational Forms ....................................13

Social Enterprise Funding and Narratives .....................................................15

Chapter 3 A Review of the Literature on Resource Acquisition ...........................18

Entrepreneurial Resource Acquisition ....................................................... 18

Narratives and Entrepreneurial Resource Acquisition..................................24

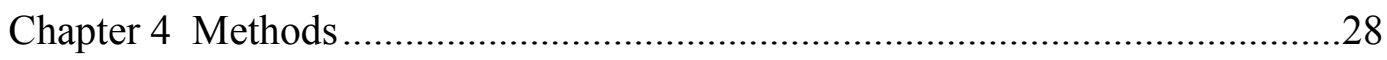

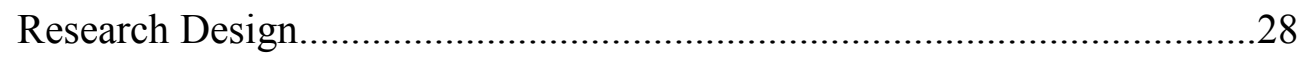

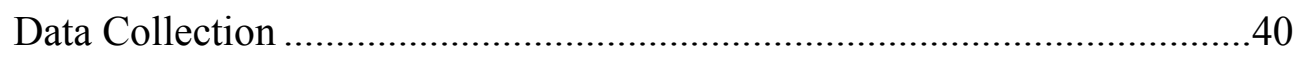

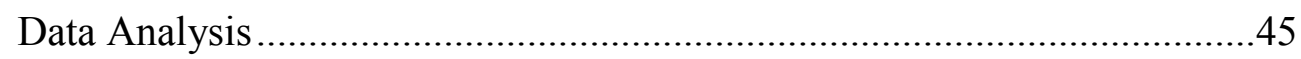

Chapter 5 What Narratives Do Social Entrepreneurs Construct? ..........................48

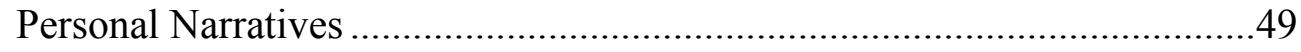

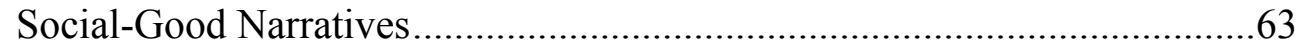

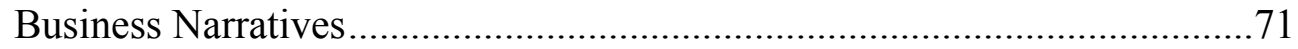

Social Enterprise Narratives: A Typology ………….................................77

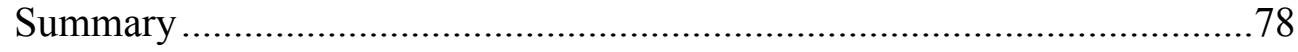

Chapter 6 How Do Social Entrepreneurs Use Narratives to Acquire Resources?

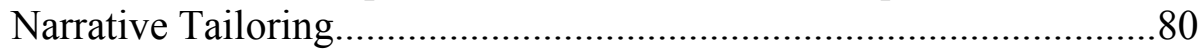

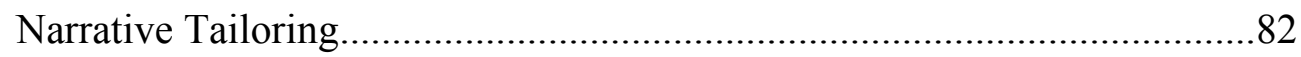

What is Social Enterprise Narrative Tailoring? …………...........................8

Tailoring: Business Narratives and Investors (Entrepreneurs' View)...........92

Tailoring: Business Narratives and Investors (Investors' Assessments).......98

Tailoring: Social-Good / Personal Narratives and Resource Providers......104

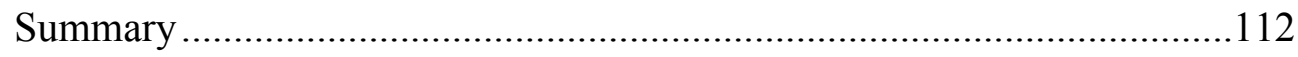


Chapter 7 How Do Social Entrepreneurs Use Narratives to Acquire Resources? Narrative Linking 115

Entrepreneurs and Narrative Linking (Evidence)......................................121

Why Do Social Entrepreneurs Use Linked Narratives? ..............................124

Are Investors Influenced By Social-Good Narratives? ...............................127

Linking Business and Personal Narratives ...............................................129

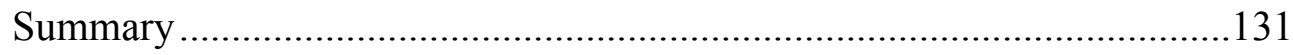

Chapter 8 How Do Social Entrepreneurs Use Narratives to Acquire Resources? Narrative Multiplexity .......................................................................134

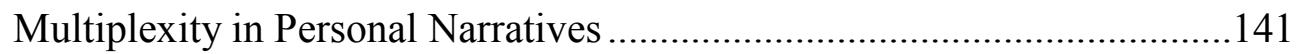

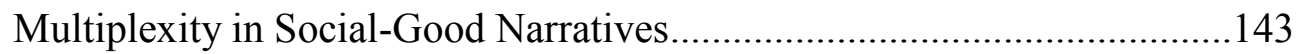

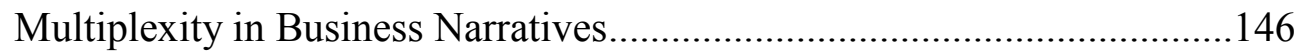

Investor Reactions to Narrative Multiplexity ............................................150

Evidence that Unsuccessful Ventures Are Not Multiplex ..........................152

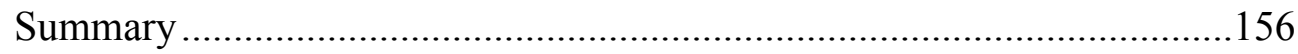

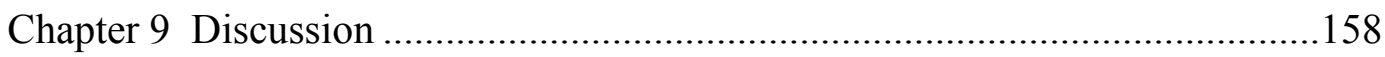

Implications for Organizational Narrative Theory ..................................160

Implications for Entrepreneurial Resource Acquisition .............................161

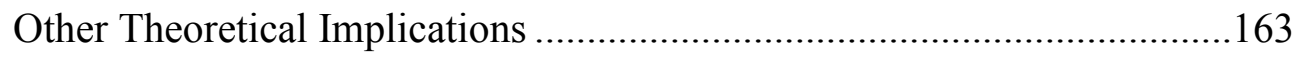

Implications for Institutional Logics..................................................163

Implications for Emotion and Stakeholder Evaluations .....................165

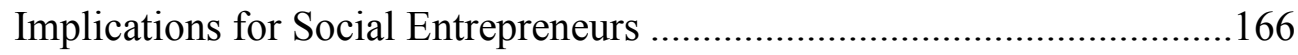

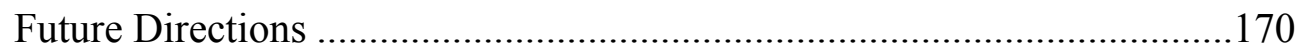

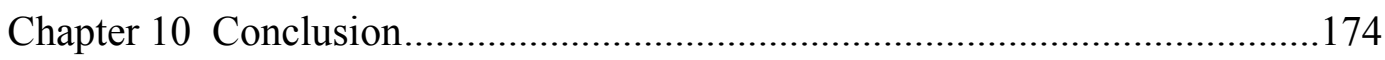

Appendix A How Do Social Enterprise Narratives Change Over Time?...........178

What Prevents Entrepreneurs from Gettting "Stuck"? ..............................185

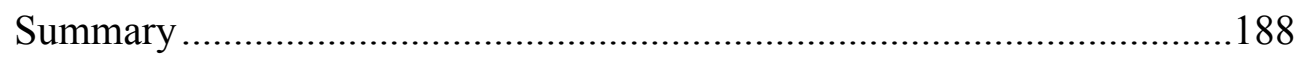




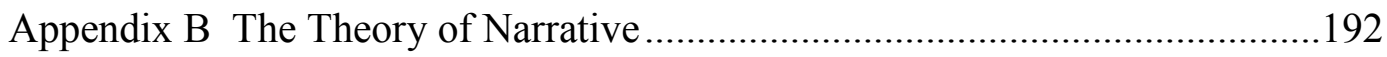

Appendix C A Review of the Practitioner Literature and Pilot Interviews .......237

Appendix D Additional Tables ......................................................................261

Appendix E Interview Guide and Participant Consent Form .............................264

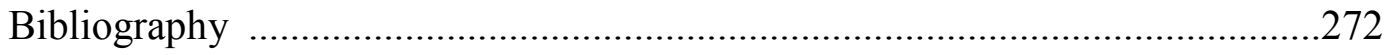

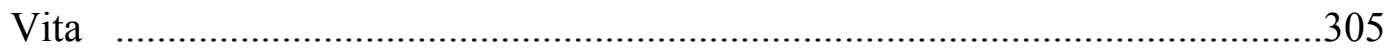




\section{List of Tables}

Table 1: Description of Study 1 Informants: Social Entrepreneurs ..................30

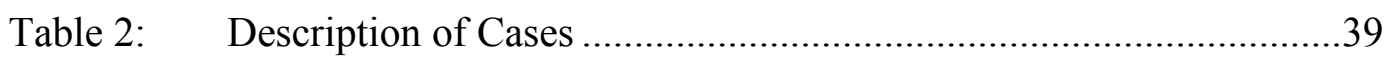

Table 3: Timeline of Funding and Data Collection ..........................................42

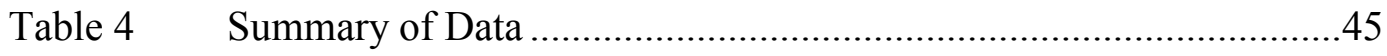

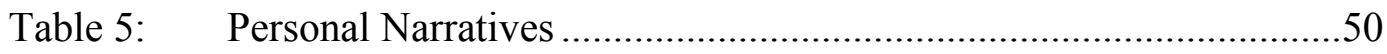

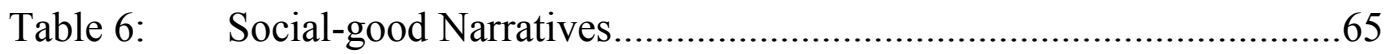

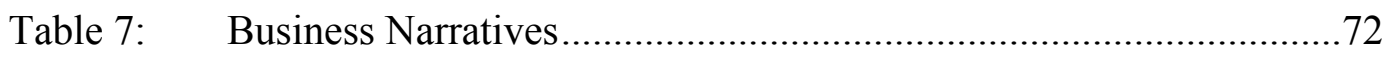

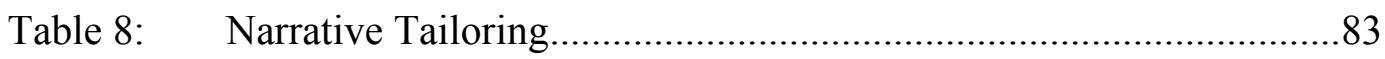

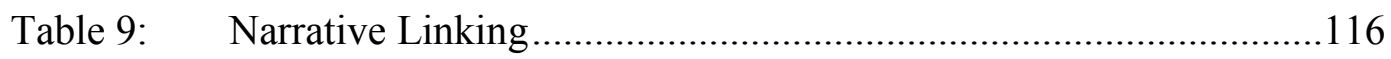

Table 10: Personal Narrative Multiplexity.....................................................135

Table 11: Social-good Narrative Multiplexity …………………………….......143

Table 12: Business Narrative Multiplexity .....................................................147

Table 13: Description of Pilot Interview Participants.....................................252

Table 14: Description of Study 1 Informants: Funders.....................................261

Table 15: Description of Study 1 Informants: Other Participants....................263 


\section{List of Figures}

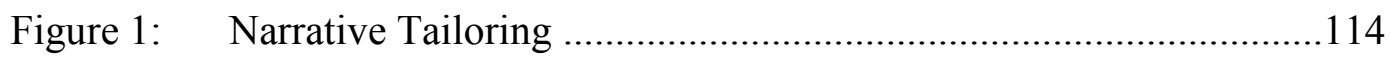

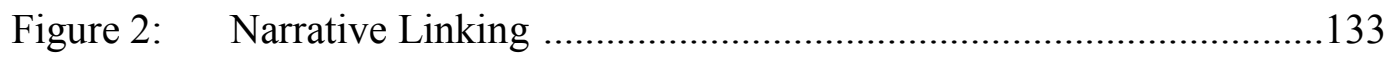

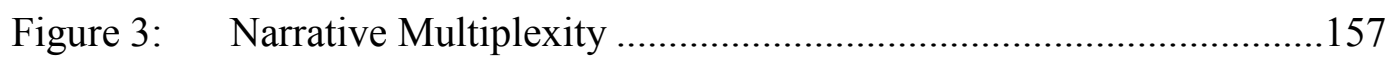

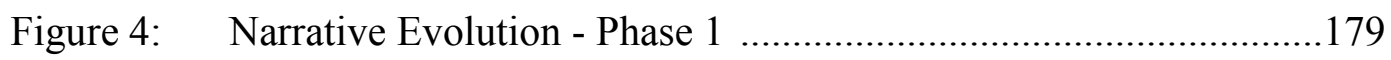

Figure 5: Narrative Evolution - Phase 2 .................................................. 180

Figure 6: Narrative Evolution - Phase 3 …...............................................181 


\section{CHAPTER 1:}

\section{INTRODUCTION}

'If a story is not about the hearer he [or she] will not listen. And I here make a rule - a great and lasting story is about everyone or it will not last.'

John Steinbeck, East of Eden

'The basic problem that social entrepreneurs face is persuading the rest of the worldparticularly potential funders - that the basic concept is both important and viable.'

Elkington and Hartigan, The Power of Unreasonable People

Social enterprises address conditions harmful to society (e.g. homelessness) using business, or market-based, methods. Social entrepreneurs create such organizations by identifying a social problem, discovering (or creating) opportunities based on it, and developing an innovative means of addressing the problem that generates social and economic value (Martin \& Osberg, 2007; Dees, 1998; Mair \& Marti, 2006)ํ. As a sector, social entrepreneurship is experiencing rapid growth (Fayolle \& Matlay, 2010) and is attracting increasing amounts of entrepreneurial talent, funding, and attention (Martin \& Osberg, 2007).

The vitality of social enterprise, in both developed and emerging economies, has recently generated attention from scholars (Mair \& Marti, 2006). Indeed, social entrepreneurship is receiving growing interest in several domains across the social sciences including economics (e.g. Parker, 2009), political science (e.g. Korosec \& Berman, 2006), sociology (e.g. Vasi, 2009), and organization theory and entrepreneurship

\footnotetext{
1 A universal definition of a "social problem" does not exist (Mooney, Knox, \& Schacht, 2000: 2-3); instead, such problems are defined by objective, subjective, and normative criteria. The objective element refers to the existence of a particular social condition, while the subjective and normative elements are the beliefs that the condition is harmful to a segment of society and that it can and should be changed.
} 
(e.g. Austin, Stevenson, and Wei-Skillern, 2006). Within the management discipline, studies have focused on foundational issues such as establishing a clear and agreed upon definition of the concept (e.g. Martin \& Osberg, 2007), understanding how social entrepreneurship differs from seemingly related concepts, such as corporate social responsibility (e.g. Baron, 2007), and identifying the individual-level characteristics of social entrepreneurs (as well as exploring whether such traits indeed exist; Light, 2009).

Despite increasing academic interest in social entrepreneurship, much remains to be learned. One critical issue that has yet to receive attention from scholars is how social entrepreneurs acquire the resources they need. Like traditional entrepreneurs, social entrepreneurs must assemble financial capital and other resources (e.g. media attention) in order to launch and grow their organizations (Davila, Foster, \& Gupta, 2003). Indeed, in a 2009 survey of 962 UK-based social enterprises, $56 \%$ of respondents claimed that financing was the most significant enabler of venture success; whereas over $65 \%$ claimed that lack of external investment was the most significant barrier to success (Leahy \& Villeneuve-Smith, 2010). While scholars and practitioners agree that acquiring resources is both challenging and essential, prior research provides little insight into how the resource acquisition process unfolds for social enterprises.

Research has examined resource acquisition in traditional new ventures (e.g. Bruton \& Rubanik, 2002; Venkataraman, 1997; Zhang, Soh, Wong, 2011). However, this literature has limited applicability to social entrepreneurship because social ventures differ from traditional ventures in several fundamental ways, including the types of available funders, the motivations for founding, the nature of the opportunities pursued, 
the constraints on social entrepreneurs' actions, and the difficulties they face measuring performance (Derwall, Koedijk, \& Ter Horst, 2011; Austin et al., 2006; Zahra et al., $2009)^{2}$. This suggests that the process by which social entrepreneurs gather resources represents both an important empirical phenomenon and a significant omission in the prior literature. In this dissertation I examine the following, general research question: How do social entrepreneurs acquire the resources they need?

Because of the lack of prior theory on this topic, and the limited theory in social entrepreneurship research more generally (Dacin, Dacin, \& Tracey, 2011), to address this research question I used a multi-study, partially-inductive design aimed at building empirically-grounded theoretical insights. As is common in inductive, theory-building studies, early data collection led to further refinements of the above research question. Specifically, a pilot study and a review of the practitioner literature on the topic of social venture fundraising, honed the research question by suggesting that the narratives communicated by social entrepreneurs may play a particularly important role in social enterprise resource acquisition ${ }^{3}$.

Since prior research has not catalogued the themes and characteristics that constitute social enterprise narratives, in Study 1 I sought to create a typology of such narratives and to answer the following more specific research question, "What narratives do social entrepreneurs construct?" In the study I conducted 75 interviews with entrepreneurs, investors, and other participants in the social enterprise sector. The

\footnotetext{
2 "Social venture" and "social enterprise" are used interchangeably.

${ }^{3}$ For the purposes of this study, a narrative is defined as a collection of events arranged in a temporal sequence and containing a causal explanation (Onega \& Landa, 1999). More details about this choice of definition are provided in Appendix B.
} 
findings demonstrate the existence of three narrative-types (personal, social-good, and business) each possessing unique, constitutive elements. These narrative-types, and their themes and characters, serve as the buildings blocks for social entrepreneurs' communication with external stakeholders, and particularly investors and the media.

Study 1 also suggested that there are differences between social entrepreneurs in how they use the three narrative-types in resource acquisition. For instance, some social entrepreneurs used different narratives with different resource providers, whereas others communicated the same narrative to all audiences. The study also suggested that these differences may be associated with entrepreneurs' ability to acquire resources.

Thus, in Study 2 I focus specifically on the following research question, "How do social entrepreneurs use narratives to acquire resources?" To examine this question I constructed case studies of eight technology-focused social enterprises. Case studies were created from 34 additional interviews (not included in Study 1) and from archival data. Five of the ventures represented "successful" resource acquirers, with success defined as securing a round of external, financial investment; three were not successful (i.e. at the completion of the study they had not received investment). Financial investment is emphasized because it is an especially important resource for new ventures that often influences the acquisition of other resources, such as legitimacy and media attention (e.g. Shane, 2012; Engel \& Keilbach, 2007; Hsu, 2004). Moreover, as described, social entrepreneurs contend that receiving financing is the most significant enabler of venture success. 
Results from this study indicate that the successful social enterprises used narratives differently than the unsuccessful enterprises. Specifically, successful social entrepreneurs engage in narrative tailoring, which is adapting the emphasis of a narrative to match the interests of a particular audience. Findings also illustrate that, rather than using the narrative-types in isolation, successful social entrepreneurs utilize combinations of the three narratives - i.e. they engage in narrative linking. Finally, I provide evidence that an important characteristic of social enterprise narratives is their multiplexity - i.e. the potential ties they contain to multiple stakeholder groups. Multiplex narratives contain several ways to frame the social venture, which creates multiple, potential connections to customer and beneficiary groups.

Together, these findings create a framework that explains how differences in social entrepreneurs' use of narratives are associated with differences in their resource acquisition success. In addition to its contribution to the social enterprise literature, the theoretical framework developed also contributes to the two other primary literatures that inform this study: organizational narrative theory and entrepreneurial resource acquisition.

First, the framework contributes to organizational narrative theory by shedding light on several important features of narratives heretofore unexamined. For instance, although prior work has acknowledged that multiple narratives can exist within an organization (e.g. Humphreys \& Brown, 2002), these narratives are often assumed to be in conflict (i.e. inconsistent with one another). Evidence presented in this study suggests that social entrepreneurs create three primary narrative-types, which they use to 
emphasize different (but non-conflicting) facets of their venture to different audiences. Research has not focused on a firm's ability to construct multiple, consistent narratives and, thus, has not examined how such stories can be combined. This study reveals that not only can narrative-types be linked but that doing so can increase the persuasiveness of communication.

Second, the findings contribute to the literature on entrepreneurial resource acquisition by uncovering new and previously unexamined factors that can influence resource acquisition. Moreover, unlike much of the prior work on resource acquisition, this study captures investors' evaluations and beliefs first-hand rather than measuring external investment as a dichotomous outcome or by focusing solely on the dollar amount of funding. By doing so, several insights and nuances are revealed about the thoughtprocesses investors engage in when evaluating ventures.

This study stands to contribute to two other topics of organizational research: competing institutional logics and emotion in stakeholder evaluations. The framework adds to the literature examining competing logics by providing evidence that social enterprises represent an organizational form that fosters two dominant logics: social welfare and economic. Social enterprises not only must achieve operational co-existence of the logics but must also develop a proficiency in communicating about these logics with stakeholders (who themselves are often rooted in one logic or the other). In addition, extending recent work by Battilana \& Dorado (2010), which finds that the multiple logics of hybrid organizations can influence their management of human resources, this study finds that multiple logics can influence other types of resources, such as those provided 
by investors and the media. Understanding how social entrepreneurs use strategies such as narratives to navigate the tension between their logics has uncovered insights into how other types of organizations can balance multiple logics and communicate about them to resource providers.

Finally, the findings also contribute to work on the role of emotion in stakeholder evaluations. Unlike other studies (e.g. Martens et al., 2007), which focus exclusively on narrative's ability to influence cognition-based constructs, such as categorization, this study begins to shed light on how narratives can influence resource acquisition through affective (i.e. emotion) mechanisms. The study's findings suggest that the emotion conveyed through social enterprise narratives can serve several roles, including capturing investor (and media) attention, influencing investors' beliefs and perceptions, creating connections between social enterprises and investors and, ultimately, influencing investors to commit resources to an organization.

In addition to its theoretical contributions, this research has normative implications for social entrepreneurs seeking resources and particularly for those trying to acquire external investment. First, and most generally, social entrepreneurs should be mindful of the narratives they construct and communicate to external stakeholders (i.e. the creation and deployment of narratives should not be viewed as "mere storytelling"). Indeed, this study provides evidence that narrative use (and misuse) can have serious ramifications, particularly in fundraising.

More specifically, although debates rage in the practitioner literature about what type of narrative social entrepreneurs should develop and emphasize - a "social 
message" or an "economic message" - framing the debate as an either-or decision is not helpful. Both narrative-types are necessary, serve a different purpose, and can work in tandem. In fact, as will be described, it is important for social entrepreneurs to develop all three narrative-types - business, social-good, and personal - and to develop a complex set of linkages between them.

This dissertation begins by reviewing the academic literature on social entrepreneurship (Chapter 2). I pay particular attention to research focusing on the definition of social entrepreneurship and how the concept is distinct from related phenomena, including traditional entrepreneurship. Although this body of research does not directly address social enterprise resource acquisition, it is foundational for understanding the phenomenon. I then review the entrepreneurial resource acquisition literature (Chapter 3). In particular, I emphasize research examining resource acquisition strategies and the small stream of research that focuses on the role of narratives in resource acquisition. Next, I discuss the inductive methodology used for the empirical portion of the study (Chapter 4). As noted above, observations from pilot interviews and practitioner writings suggest that narratives play a key role in resource acquisition for social ventures. Therefore, I used the literature on narratives (reviewed in Appendix B) in a sensitizing role during data collection and analysis. I then describe my main findings, which correspond to two questions: What narratives do social entrepreneurs construct (Chapter 5)? And, how do social entrepreneurs use narratives to acquire resources (Chapters 6-8)? Next, I provide a discussion of these findings, including their 
contributions to several literatures and implications for managers and social entrepreneurs (Chapter 9). Finally, I present the conclusions of the study (Chapter 10). 


\section{CHAPTER 2:}

\section{A REVIEW OF THE LITERATURE ON SOCIAL ENTREPRENEURSHIP}

In this chapter, I review the academic literature examining social enterprise. Particular attention is paid to issues that are foundational to the concept, such as the definition of social entrepreneurship, how it is unique from related phenomena (e.g. corporate social responsibility, nonprofit organizing), and the distinction between social and traditional entrepreneurship.

\section{What is a Social Enterprise?}

There is no universally accepted definition of "social enterprise" (Tan, Williams, \& Tan, 2005; Martin \& Osberg, 2007) ${ }^{4}$. There are, however, several widely agreed upon dimensions of the concept (Brouard \& Larivet, 2011). For the purposes of this analysis, a definition that incorporates these commonly agreed upon elements will be used. In particular, social enterprises are defined as organizations that address conditions harmful to society through business methods (Austin et al., 2006). Social entrepreneurs are the individuals that create such organizations. In doing so, they identify a social problem (or social need), use innovative and entrepreneurial means to address it, and create both economic and social value. Each of these characteristics is examined in more detail.

\section{The Identification of a Social Problem (Opportunity)}

There is growing evidence that economic, social-service, and political institutions are unable to serve the needs of large segments of the world population (e.g. Sachs, 2009

\footnotetext{
${ }^{4}$ The lack of an established definition is argued to be evidence that the study of social entrepreneurship is in a "pre-paradigmatic" stage (Kuhn, 1970; Nicholls, 2010; Santos, 2009).
} 
Mair, 2011). These needs are the result of social problems - or "social-market failures" (Weisbrod, 1977) - that have not or cannot be tackled by traditional organizations in the commercial and governmental sectors. The primary activity of social entrepreneurs, beyond the creation of new ventures, is meeting these unaddressed needs (Fayolle \& Matlay, 2010; Alvord et al., 2004). For instance, social enterprises address problems such as poverty, social inequality, and environmental degradation. They do so by creating ventures that allow them to modify the cultural and economic structures that produce social needs (Mair, 2011). Thus, consistent with the above definition, a primary driver for social entrepreneurship is the social problem being addressed (Austin et al., 2006) ${ }^{5}$. In fact, for many social enterprises the amelioration of a particular social problem is so fundamental to their mission that it is said to be "baked in" to the organization's business model (Boyd, Henning, Reyna, Wang, Welch, 2009).

\section{Entrepreneurial Activity}

Social entrepreneurs do not merely attempt to address social problems; they do so by engaging in activities that are innovative and entrepreneurial (Dees, 1998; Brouard \& Larivet, 2011). These activities involve creating new sources of economic and social value rather than replicating extant practices or mimicking existing enterprises. In this way, social and traditional entrepreneurs are similar in that they both strive to "reform or revolutionize the pattern of production" (Schumpeter, 1950: 13). Moreover, like traditional entrepreneurs, social entrepreneurs often take innovative actions without

\footnotetext{
${ }^{5}$ Similar to the distinction made between opportunity discovery and creation (e.g. Alvarez \& Barney, 2007; Butler, 2004), a distinction can also be made between "unmet social needs" and social enterprise "opportunities" (Cajaiba-Santana, 2010). A social need (or social problem) is a necessary but not sufficient condition for the existence of a social opportunity; an opportunity can be viewed as arising when social entrepreneurs set to induce changes in the environment to address a social need (Cajaiba-Santana, 2010).
} 
regard to the resources they currently control (Dees, 1998). Thus, they are innovative in both resource deployment and creation.

\section{Social and Economic Value Creation}

After identifying a need, a social entrepreneur's goal is to ameliorate the problem through the creation of social value (Auserswald, 2009). Social value is defined as "benefits or reductions of costs for society - through efforts to address needs and problem - in ways that go beyond the private gains and general benefits of market activity" (Phills, Deiglmeier, \& Miller, 2008: 39; emphasis added). As the definition describes, social value is distinct from private value, which is the benefit accrued to the parties directly engaged in a market transaction (Auserswald, 2009) ${ }^{6}$.

Social value can take several general forms, including the provision of goods and services, the creation of missing institutions, and the reshaping of inadequate institutions (Mair, 2011). Since traditional entrepreneurs can also engage in these types of activities, they can also be agents that create social value (Auerswald, 2009). However, one of the key differences between the two types of entrepreneurs (which will be expanded upon in the next section) is that social entrepreneurs place the creation of social value on par with the creation of private value (Zadek \& Thake, 1997; Austen et al., 2006). In other words, in social enterprises the production of social value is not secondary to the creation of private profit or shareholder wealth. Thus, the relationship between social and traditional (i.e. commercial) entrepreneurship is not dichotomous. Rather, the two activities can be viewed as existing on a continuum ranging from new ventures with predominantly social

${ }^{6}$ Defined this way, social value is similar to, but broader than, the economic concept of a "positive externality" (cf. Santos, 2009) 
to predominantly economic motives (Sundin \& Tillmar, 2010). On this continuum, social entrepreneurship can be seen as ending where profits and commercial activities take priority over social mission (Hervieux \& Turcotte, 2010) ${ }^{7}$.

Finally, it is important to note that, like social enterprises, traditional non-profit organizations also have the creation of social value as a main aim. But what distinguished a "pure" non-profit from a social enterprise is that, whereas traditional non-profits often make little effort to generate economic value, social entrepreneurs strive to produce both social and economic wealth (Fayolle \& Matlay, 2011). Indeed, it has been argued that the two "structuring components" (i.e. governing logics) of social entrepreneurship are the “economy and social well-being” (Fayolle \& Matlay, 2010: 2).

How social enterprises differ from other organizational forms, and particularly certain types of non-profit organizations, is a contentious - but critical - topic. In order to clarify the distinction, the following section discusses the issue in greater detail.

\section{Social Enterprise and Related Organizational Forms}

There is at least some overlap between social entrepreneurship and other types of organizing (e.g. nonprofits, charities). The degree of this overlap is attributable to the fact that, while most definitions of social entrepreneurship include a focus on the common elements of social problems, entrepreneurial activity, and the creation of economic and social value, the extent each of these characteristics is emphasized differs across studies. The result is that the definition of social enterprise is applied either broadly or narrowly.

\footnotetext{
${ }^{7}$ Despite their differences, there are some similarities between social and traditional entrepreneurs. For instance, both groups require proficiency in opportunity recognition (Corner \& Ho, 2010). Moreover, social and traditional entrepreneurs can also share qualities such as risk-taking, proactiveness, and independence (Zahra et al. 2009).
} 
For instance, a broad application allows the term "social entrepreneurship" to be applied to for-profit commercial ventures, initiatives within large corporations, organizations in the nonprofit sector, and hybrid organizations that mix for-profit and nonprofit approaches (Austin et al., 2006). In contrast, a narrow application, for instance emphasizing the creation of economic value, allows only for-profit new ventures with a social purpose to be labeled social enterprises.

For the purposes of this study, a definition of moderate scope will be used. In particular, social enterprises can be for-profit, non-profit, or hybrid legal forms. But, consistent with the characteristics described above, the organization must address a social problem in an innovative way and generate social and economic value (i.e. there is a substantive earned-income component to the business model).

A focus on these characteristics clearly removes some organizations from consideration. For instance, the requirement that the firm be innovative means that noninnovative non-profits are not social enterprises. This is akin to the distinction that not all for-profit businesses are entrepreneurial (Carland, Hoy, Boulton, Carland, 1984). Likewise, even among innovative non-profits, those not striving to create substantial economic value (e.g. many social service organizations and NGOs) are also not classified as social entrepreneurs (Zahra et al., 2009). Similarly, established corporations that engage in philanthropic activity that creates social value, but that do not have this activity as their primary focus, are also not social entrepreneurs (these activities are more accurately labeled corporate social responsibility; Carroll, 1999). Finally, although the term "social entrepreneurship" was coined in the mid-1970s (and popularized in the 
1990s), it can be argued that it is not an entirely new phenomenon (e.g. Fayolle \& Matlay, 2010). Cooperative movements, mutual benefit associations, and cooperative enterprises from the 19th century are often argued to be early social enterprises (Rispal \& Boncler, 2010). Insofar as these (and other) organizations satisfy the three defining characteristics of social entrepreneurship, outlined above, for the purposes of this study they are classified as social enterprises.

\section{Social Enterprise Funding and Narratives}

Despite widespread agreement in the social enterprise community that funding is a significant challenge (Leahy \& Villeneuve-Smith, 2010), to date work examining social entrepreneurship resource acquisition is nonexistent. The only study (empirical or conceptual), examining this issue is Miller \& Wesley (2010). In a "policy capturing" (cf. Aiman-Smith, Scullen, \& Barr, 2003) study of the decision rules of 44 social venture

capitalists (SVCs), they examine how the "dual identities" of social entrepreneurs (grounded in both social and economic value creation) influence SVCs' decisions. They find that SVCs use both social and economic criteria. Specifically, they show that SVCs assessments of the probability of a social entrepreneurs' effectiveness are positively related to several "social" factors, including the ventures' social mission, communitybased network, and the founders' passion for change. Perceptions of effectiveness were also related to several economic factors, including the ventures' innovation capabilities, ability to generate earned income, and founders' business experience.

An additional topic receiving virtually no systematic attention in the academic literature is the role of narratives in social enterprise. Studies have, however, hinted at the 
importance of narratives and storytelling in the establishment, funding, and actions of social ventures. For instance, in a recent review of the social enterprise literature, Dacin, Dacin, and Tracy (2011: 1205) remark that the "individuals identified as social entrepreneurs provide the material for rich and powerful narratives.” However, narratives receive only a passing mention. To date, only one study of social entrepreneurship has placed narratives at the center of the analysis. In a case study (with a single informant) of a social entrepreneur who founded a refugee support center in Australia, Jones, Latham, and Betta (2008) examined how the social entrepreneur created his identity. In agreement with work outside the entrepreneurial context (e.g. McAdams, Josselson, \& Lieblich, 2006; Ibarra \& Barbulescu, 2010), they found that the entrepreneur constructed his identity by crafting narratives.

As previously described, the dearth of (academic) research examining social enterprise narratives is coupled with a more general lack of social entrepreneurship research with a theoretical grounding. Indeed, it has been argued that most of the work examining social entrepreneurship is descriptive and atheoretical (Dacin, Dacin, \& Tracy, 2011). For instance, many studies are overly focused on describing the actions of a small number of notable social entrepreneurs rather than on understanding the general processes whereby social ventures develop (Corner \& Ho, 2010). In addition, only a limited number of studies have tried to incorporate ideas from existing theoretical frameworks and perspective [exceptions include Battilana \& Dorado, 2010 (institutional theory); Paredo \& Chrisman, 2006 (social network theory); Mair \& Marti, 2006 (structuration theory)]. For instance, Short et al. (2009) found that less than a third of the 
articles reviewed cited other research streams as the basis of theory development. Indeed, based on their review, they concluded that "scholarly progress in social entrepreneurship research will not accelerate until theoretical relationships become more explicit" and "explicit predictions informed by sound theory" are included (Short et al., 2009: 173). Thus, a significant opportunity exists to examine social entrepreneurship, and particularly social enterprise resource acquisition and narrative use, in a theoretically and methodologically rigorous manner. 


\section{CHAPTER 3:}

\section{A REVIEW OF THE LITERATURE ON ENTREPRENEURIAL RESOURCE ACQUISITION}

In this chapter, I review the entrepreneurial resource acquisition literature. In particular, I emphasize work examining resource acquisition strategies and the small stream of research that has explored the role of narratives in seeking resources. The latter is argued to be relevant because it motivates several important theoretical questions this study seeks to address.

\section{Entrepreneurial Resource Acquisition}

Resources, an organization's bundle of tangible and intangible assets and capabilities (Amit \& Schoemaker, 1993), are fundamental to firm growth (Penrose, 1959; Wernerfelt, 1984), competitive advantage (Barney, 1991; Peteraf, 1993), and performance (Rumelt, 1984; Newbert, 2008; Crook, Combs, Ketchen, \& Todd, 2008). Because of their ubiquitous role in organizational processes and outcomes, scholars have focused on several issues related to resources and resource-use, such as identifying what resource characteristics are critical for competition (e.g. Barney, 1991; Dierickx \& Cool, 1989) and understanding the influence of resource sharing (Gupta \& Govindarajan, 1986), bundling and deployment (Sirmon, Gove, \& Hitt, 2008; Capron, Dussauge, \& Mitchell, 1998), allocation (Conlon \& Garland, 1993), and construction (Baker \& Nelson, 2005). 
A key finding from these and other streams of work is that organizations are not self-sufficient: resources that cannot be produced internally (Baker \& Nelson, 2005) must be obtained from external stakeholders (Pfeffer \& Salancik, 1978; Scott, 1998). Firms are dependent on, and often constrained by, external sources for a significant portion of their resource needs (Bode, Wagner, Petersen, Ellram, 2011) ${ }^{8}$. These resource providers include investors, creditors, suppliers, customers, governmental agencies, and the media (Barringer \& Harrison, 2000; Zott \& Huy, 2007). Since providers do not have an unlimited supply of resources and, hence, cannot fulfill every organization's needs, firms must engage in attempts at influencing the allocation decisions of resource holders (Wernerfelt, 2011).

Although most prior research has focused on resource acquisition in mature firms (e.g. Greve, 2011; Das \& Teng, 2000), a growing body of work examines how nascent organizations obtain resources from external sources (Bruton \& Rubanik, 2002; Jarillo, 1989; Venkataraman, 1997; Zhang, Soh, Wong, 2011). These studies find that a new venture's ability to acquire and mobilize both financial and nonfinancial resources is critical for firm survival and growth (e.g. Brush, Greene, \& Hart, 2001; Eisenhardt \& Schoonhoven, 1990). Acquiring resources is, however, a difficult task and, arguably, "the greatest challenge faced by entrepreneurs" (Brush et al., 2001: 71).

In particular, new ventures face several problems related to establishing and growing their resource base. These challenges are generally attributable to a liability of

\footnotetext{
${ }^{8}$ A number of recent studies, however, question the classical assumption of early resource dependence theorists (Pfeffer \& Salancik, 1978) and suggest that, in fact, resource seekers and resource providers share a mutual dependence (Villanueva, Van de Ven, \& Sapienza, 2012; Gulati and Sytch, 2007; Casciaro and Piskorski, 2005).
} 
newness (Aldrich \& Auster, 1986; Shane, 2000; Stinchcombe, 1965), which manifests in several ways. First, new ventures lack a track record of proven competencies, which creates uncertainty for resource providers (Stinchcombe, 1965; Zott \& Huy, 2007). Lack of a proven business model, coupled with the high risk associated with the entrepreneurial process, makes it difficult for resource holders to assess the quality of a new venture and, more fundamentally, its probability of success (Shepherd, 1999; Zott \& Huy, 2007).

Uncertainty is exacerbated by information asymmetry (Shane, 2000). Since entrepreneurs generally possess more information than outside evaluators about the prospects of their businesses and the competence of founders and the management team, resource providers face challenges when trying to verify entrepreneurs' ability to provide them with high returns on their resources (Zhang, Soh, Wong, 2011; Amit, Brander, and Zott, 1998). In addition to having less knowledge than entrepreneurs about the intrinsic characteristics of the venture, resource providers also often possess less information about the extrinsic value of the opportunity being exploited (Shane, 2003). The evaluation of an opportunity is particularly difficult when a venture has not yet made an attempt to exploit it (i.e. when the venture is in the "idea" phase; Marten et al., 2007). Information asymmetry may be further exacerbated because, in young firms, it can be difficult for managers to articulate the detailed information about the venture that resource providers desire (Winborg \& Landstrom, 2000). Even if entrepreneurs can provide such information they may be reluctant to do so because of fears that critical 
information about their core competencies may leak through to competitors and, thus, compromise the firm's competitive advantage (Winborg \& Landstrom, 2000).

\section{Resource Acquisition Strategies}

The result of uncertainty and information asymmetry is that resource holders are reluctant to commit resources to new ventures (Schoonhoven and Romanelli, 2001; Hellmann, 2002; Zott \& Huy, 2007). Intense competition among new ventures for resources (Carroll \& Hannan, 1989), along with the scarcity of these resources, means that nascent organizations cannot wait passively for resource providers to notice and invest in their activities (Romanelli \& Schoonhoven, 2001). Most research has focused on two, related sets of actions that entrepreneurs take to cope with these challenges: leveraging networks and building legitimacy (Martens et al. 2007).

Social networks, comprised of direct and indirect ties between new ventures and resource providers, can improve entrepreneurs' ability to acquire resources by facilitating the transfer of information between parties and, thus, by reducing information asymmetry (Venkataraman, 1997; Zhang, Soh, Wong, 2011). Moreover, a new venture's social network, and particularly its ties to high-status partners (e.g. venture capital firms, prestigious board directors) can act as a signal to resource providers of the quality of the venture and its business model (Shane \& Cable, 2002; Stuart et al., 1999; Florin, Lubatkin, and Schulze, 2003; Martens et al. 2007) ${ }^{9}$.

\footnotetext{
${ }^{9}$ In addition to external relationships, internal factors, such as the caliber of the founding team (Eisenhardt \& Schoonhoven, 1990) and characteristics of business planning (Delmar \& Shane, 2003; MacMillan, Siegel, \& Narasimha, 1985) can also be signals of new venture quality.
} 
For instance, in a study of high-tech entrepreneurs, Zhang, Soh, and Wong (2011) found that indirect ties, in which a referrer exists between an entrepreneur and a resource owner, enhanced the likelihood of resource acquisition. The authors argue that the presence of referrers increases the flow of resources because they help to lessen the information asymmetry between entrepreneurs and resource owners. Similarly, Starr and MacMillan (1990) argue that resource acquisition is often the result of a process of "social contracting" whereby entrepreneurs obtain resources by exploiting their social assets. These assets include obligations, expectations, and mutually developed norms that evolve from ties formed in prior social interactions.

Hallen (2008) provides evidence of how entrepreneurial social relationships are formed. Specifically, in a study of how new firms form relationships with venture capitalists (a significant resource provider), the author found that when new organizations formed their ties early, they obtained their initial network position through founder ties and human capital; whereas when new organizations formed their first ties later, they achieved their network position through their organizational accomplishments. In a companion to the previous study, Hallen and Eisenhardt (2012) conduct an inductive field study of nine Internet security ventures seeking investment ties. They find that there are two "equifinal" paths for how new ventures form ties. Specifically, privileged firms rely on existing direct ties, while other, lower-status firms rely on "catalyzing strategies", a means by which executives advantageously shape opportunities and inducements to form ties available to many firms. 
In addition to leveraging their social networks, it is also critical for entrepreneurs to build legitimacy during the early stages of a venture (Stinchcombe, 1965; Aldrich \& Fiol, 1994; Lounsbury \& Glynn, 2001; Zimmerman \& Zeitz, 2002; Zott \& Huy, 2007). Legitimacy is "a generalized perception or assumption that the actions of an entity are desirable, proper, or appropriate within some socially constructed system of norms, beliefs, and definitions" (Suchman, 1995: 574). Legitimacy is itself a resource, which is necessary for the acquisition of other resources (Zimmerman \& Zeitz, 2002). If resource providers do not grant legitimacy to a new venture and its actions, then they will be less likely to invest resources, such as human and financial capital (Zott \& Huy. 2007).

However, entrepreneurs can take strategic action to gain legitimacy (Lounsbury \& Glynn, 2001). For instance, in a study of new ventures in an emergent Internet sector, Sine, Mitsuhashi, and Kirsch (2006) found that, contrary to Burns \& Stalker (1961) who argue that organic structures are more effective in dynamic environments, new ventures with higher founding team formalization, specialization, and administrative intensity outperformed those with more organic organizational structures. They argue that this finding is attributable to the legitimacy firms gain by formalization, in part, counteracting ventures' liability of newness.

Finally, it is important to note that legitimacy building and the formation of social ties are not unrelated activities. One of the primary ways that entrepreneurs demonstrate to evaluators that their ventures are desirable, proper, and appropriate is by forming relationships with high-status individuals and firms (Hallen, 2008). Yet, these high-status partners will be reluctant to form such relationships if they do not believe a firm's actions 
are legitimate (Hitt, Ahlstrom, Dacin, Levitas, \& Svobodina, 2004). Thus, legitimacy and the creation of social capital are intimately linked.

Prior work examining how ventures acquire resources has been criticized for not providing a full understanding of the mechanisms underlying how firms' existing resources are leveraged to attract additional resources (e.g. Lounsbury \& Glynn, 2001; Zott and Huy, 2007). To address this issue, Zott and Huy (2007) argue for focusing on the behaviors that entrepreneurs engage in to obtain resources. In a study of symbolic actions (i.e. "actions in which the actor displays or tries to draw other people's attention to the meaning of an object or action that goes beyond the object's or action's intrinsic content or functional use") taken by British new ventures to acquire resources, the authors found that there were four symbolic action categories that facilitated resource acquisition. Specifically, symbolic actions (e.g. taking a prestigious investor along to a supplier negotiation) were taken to convey the entrepreneur's personal credibility, professional organizing, organizational achievement, and the quality of stakeholder relationships. Entrepreneurs who performed a variety of symbolic actions from the previous categories had more success obtaining resources than those that did not engage in these activities.

\section{Narratives and Entrepreneurial Resource Acquisition}

Although not a focus of their study, Zott and Huy's (2007) findings suggest that how entrepreneurs convey actions to stakeholders is key to convincing resource owners to commit resources. In fact, an emphasis on communication between resource seeker and provider has led to the development of an additional stream of research, which draws on 
multiple theoretical perspectives (e.g. legitimacy, identity) and examines how the narratives entrepreneurs use to describe their ventures, products, and actions influence their ability to obtain resources.

A foundational work in this growing literature is Lounsbury and Glynn (2001), which builds on suggestions in prior work about the link between new venture legitimacy and founders' use of verbal strategies such as issue framing, symbolism, and rhetorical techniques (e.g. Aldrich \& Fiol, 1994). In their conceptual paper, they argue that the stories of entrepreneurs serve a function beyond mere entertainment. Rather, narratives play a critical role in the processes that enable new ventures to emerge. Specifically, stories told by (and about) entrepreneurs can help to create favorable interpretations of the wealth-creating possibilities of the venture, thus increasing the likelihood that resources will flow to the new firm. Narratives influence interpretations by creating and legitimating a new venture's identity. In this role, they are suggested to function as a mediator between extant stocks of entrepreneurial resources and subsequent resource acquisition. They define the use of narratives in this way as "cultural entrepreneurship".

Martens, Jennings, and Jennings (2007) used a mixed-methods study to also examine the role of stories in the resource acquisition attempts of entrepreneurs in hightech industries. In a study of initial public offerings (IPOs), they found that the identity constructed for a new venture in an entrepreneurial narrative had an influence on resource acquisition that was net of the influence of "actual" information about the firm's existing resource endowments. Also, stories that elaborated the rationale behind a new venture's intended actions in an entrepreneurial narrative had a positive, but diminishing, effect on 
the firm's resource acquisition ability (although highly complex rationales hindered a firm's ability to influence potential investors). Finally, narratives that embedded contextually familiar elements had a positive, but diminishing, effect on resource acquisition ability. Overall, their results suggest that particularly influential entrepreneurial narratives: (1) construct unambiguous identities for entrepreneurial firms, (2) clearly elaborate how the proposed means of exploitation will attenuate risk, and (3) invoke familiar elements to contextually ground those that are less familiar.

These studies, and others (e.g. Porac, Mishina, \& Pollock, 2002; Downing, 2005), make strides in increasing our understanding of the role of narratives in new venture resource acquisition. Several opportunities, however, remain. First, as discussed, prior work has not examined the role of resource acquisition narratives in social enterprise. But there is evidence to suggest that narratives may play a particularly potent role in social entrepreneurs' attempts to secure investment and attract media attention (see Appendix C for a review of evidence from the practitioner literature on this topic). Second, studies examining narratives in entrepreneurial resource acquisition, as well as the larger literature on organizational narrative theory, share an implicit commonality: they all emphasize narrative's ability to influence cognition-focused constructs, such as legitimacy, categorization, and sensemaking, rather than on the role of stories in shaping resource providers emotional responses to firms. But, both the comprehension of narratives and the impact they have on audiences is not purely cognitive (e.g. Coplan, 2004). Indeed, evidence suggests that emotion may play an important role in social enterprise resource acquisition (Appendix C). Third, the study of narratives in resource 
acquisition, is a nascent literature comprised of a limited number of conceptual papers and even less empirical work. There are, thus, a number of important, yet unexplored, research opportunities surrounding how new ventures, and particularly new social ventures, use narrative communication to influence the allocation and investment decisions of resource providers. 


\section{CHAPTER 4:}

\section{METHODS}

\section{Research Design}

Given the lack of prior theory in the academic literature concerning social enterprise resource acquisition, in this dissertation I used an inductive approach. I conducted a pilot study and two main studies. The latter addressed the two primary research questions (i.e. "What narratives do social entrepreneurs construct?" and "How are these narratives used?").

\section{Pilot Study}

First, a pilot study was conducted with both social entrepreneurs and investors. There were several objectives of the study including gaining a better understanding of the social enterprise context, getting preliminary insights into social enterprise resource acquisition, uncovering attributes important to the methodological design, and refining and shaping the final interview guides. Twelve individuals in the social enterprise sector, representing both entrepreneurs and funders, were formally interviewed. Moreover, I conducted an extensive review of the practitioner literature regarding social enterprise resource acquisition. In addition to the formal interviews, observation and informal interviews were conducted at three, practitioner-focused social enterprise conferences (all of which included funding competitions). Finally, I engaged in direct, participant observation of a pitch by a social entrepreneur to a large, corporate donor. 
The pilot interviews provided preliminary insights into the social enterprise resource acquisition process and helped to narrow the focus of the study to social enterprise narratives ${ }^{10}$. The study also suggested that in order to understand how narratives are used in resource acquisition it is important to formulate a typology of social enterprise narratives. (More information about the pilot including a detailed summary of its findings is included in Appendix C).

\section{Study 1}

Since a typology of social enterprise narratives does not exist in the literature, the goal of Study 1 was to create such a typology. For this study, I interviewed 75 individuals in the social enterprise sector. To increase the generalizability of the typology, informants were chosen to represent a wide range of perspectives (e.g. multiple industries and occupations). I interviewed social entrepreneurs, investors, consultants, media members, attorneys, and marketing / advertising professionals. These individuals represented 44 social enterprises (for some ventures multiple informants were interviewed), 17 funders, and 8 ancillary participants in the sector. Table 1 contains a description of the social entrepreneurs' interviewed grouped by industry focus (Appendix D contains tables describing the other types of informants). In addition, I also gathered observation data by attending practitioner conferences, social enterprise expos and tradeshows, "social" investment funds board meetings, pitches and pitch events, and the meetings of a social enterprise founding team formulating its business plan.

\footnotetext{
${ }^{10}$ Pilot interviews also offered an opportunity to test interview questions and aided in the development of interview guides for the two main studies.
} 
TABLE 1:

DESCRIPTION OF STUDY 1 INFORMANTS: SOCIAL ENTREPRENEURS

\begin{tabular}{|l|l|l|l|l|}
\hline \multicolumn{1}{|c|}{ Informant } & Position & $\begin{array}{c}\text { Social } \\
\text { Enterprise } \\
\text { Organizational } \\
\text { Form }\end{array}$ & \multicolumn{1}{|c|}{$\begin{array}{c}\text { Industry } \\
\text { Focus }\end{array}$} & $\begin{array}{c}\text { Social Enterprise } \\
\text { Description }\end{array}$ \\
\hline $\begin{array}{l}\text { Social } \\
\text { entrepreneur_1 }\end{array}$ & Founder/CEO & For-profit & $\begin{array}{l}\text { Apparel / } \\
\text { Jewelry }\end{array}$ & $\begin{array}{l}\text { Import goods from } \\
\text { artisans in } \\
\text { developing countries }\end{array}$ \\
\hline $\begin{array}{l}\text { Social } \\
\text { entrepreneur_2 }\end{array}$ & Founder/CEO & For-profit & Apparel & $\begin{array}{l}\text { Produces Fair Trade } \\
\text { shoes; buy one-give } \\
\text { one model }\end{array}$ \\
\hline $\begin{array}{l}\text { Social } \\
\text { entrepreneur_3 }\end{array}$ & Founder/CEO & For-profit & Apparel & $\begin{array}{l}\text { Produces clothes } \\
\text { using fabric from } \\
\text { weavers in emerging } \\
\text { countries }\end{array}$ \\
\hline $\begin{array}{l}\text { Social } \\
\text { entrepreneur_4 }\end{array}$ & Founder/CEO & For-profit & Apparel & $\begin{array}{l}\text { Provide Refugee- } \\
\text { produced clothing }\end{array}$ \\
\hline $\begin{array}{l}\text { Social } \\
\text { entrepreneur_16 }\end{array}$ & Founder / & For-profit & $\begin{array}{l}\text { Apparel / } \\
\text { Jewelry }\end{array}$ & $\begin{array}{l}\text { Import goods from } \\
\text { artisans in } \\
\text { developing countries }\end{array}$ \\
\hline $\begin{array}{l}\text { Social } \\
\text { entrepreneur_17 }\end{array}$ & CEO 2 & For-profit & $\begin{array}{l}\text { Apparel / } \\
\text { Jewelry }\end{array}$ & $\begin{array}{l}\text { Import goods from } \\
\text { artisans in } \\
\text { developing countries }\end{array}$ \\
\hline $\begin{array}{l}\text { Social } \\
\text { entrepreneur_30 }\end{array}$ & Director & $\begin{array}{l}\text { For-profit } \\
\text { subsidiary) }\end{array}$ & $\begin{array}{l}\text { Apparel / } \\
\text { Jewelry }\end{array}$ & $\begin{array}{l}\text { Provides refugee } \\
\text { women living in the } \\
\text { United States } \\
\text { employment and } \\
\text { educational training; } \\
\text { owned by traditional } \\
\text { nonprofit. }\end{array}$ \\
\hline
\end{tabular}


TABLE 1 (cont.)

\begin{tabular}{|c|c|c|c|c|}
\hline $\begin{array}{l}\text { Social } \\
\text { entrepreneur_19 }\end{array}$ & $\begin{array}{l}\text { Co-founder / } \\
\text { CFO }\end{array}$ & For-profit & $\begin{array}{l}\text { Apparel / } \\
\text { Jewelry }\end{array}$ & $\begin{array}{l}\text { Import goods from } \\
\text { artisans in } \\
\text { developing countries }\end{array}$ \\
\hline $\begin{array}{l}\text { Social } \\
\text { entrepreneur_44 }\end{array}$ & $\begin{array}{l}\text { Founder / } \\
\text { Director }\end{array}$ & Nonprofit & $\begin{array}{l}\text { Apparel / } \\
\text { Jewelry }\end{array}$ & $\begin{array}{l}\text { Provide employment } \\
\text { and education to } \\
\text { refugees. }\end{array}$ \\
\hline $\begin{array}{l}\text { Social } \\
\text { entrepreneur_9 }\end{array}$ & Founder/CEO & For-profit & Jewelry & $\begin{array}{l}\text { Import jewelry from } \\
\text { artisans in } \\
\text { developing countries }\end{array}$ \\
\hline $\begin{array}{l}\text { Social } \\
\text { entrepreneur_10 }\end{array}$ & Founder/CEO & For-profit & Food/Beverage & $\begin{array}{l}\text { Import goods from } \\
\text { artisans in } \\
\text { developing countries }\end{array}$ \\
\hline $\begin{array}{l}\text { Social } \\
\text { entrepreneur_11 }\end{array}$ & $\begin{array}{l}\text { Co- } \\
\text { founder/CEO }\end{array}$ & For-profit & Food/Beverage & $\begin{array}{l}\text { Import goods from } \\
\text { artisans in } \\
\text { developing countries }\end{array}$ \\
\hline $\begin{array}{l}\text { Social } \\
\text { entrepreneur_46 }\end{array}$ & $\begin{array}{l}\text { Founder / } \\
\text { Executive } \\
\text { Director }\end{array}$ & $\begin{array}{l}\text { Nonprofit / For- } \\
\text { profit }\end{array}$ & $\begin{array}{l}\text { Food / } \\
\text { Beverage }\end{array}$ & $\begin{array}{l}\text { Faith-based } \\
\text { organization focused } \\
\text { on ecumenical } \\
\text { unification; own } \\
\text { social enterprise } \\
\text { (bottled-water } \\
\text { company) }\end{array}$ \\
\hline $\begin{array}{l}\text { Social } \\
\text { entrepreneur_47 }\end{array}$ & President & $\begin{array}{l}\text { Nonprofit / For- } \\
\text { profit }\end{array}$ & $\begin{array}{l}\text { Food / } \\
\text { Beverage }\end{array}$ & $\begin{array}{l}\text { Faith-based } \\
\text { organization focused } \\
\text { on ecumenical } \\
\text { unification; own } \\
\text { social enterprise } \\
\text { (bottled-water } \\
\text { company) }\end{array}$ \\
\hline
\end{tabular}


TABLE 1 (cont.)

\begin{tabular}{|c|c|c|c|c|}
\hline $\begin{array}{l}\text { Social } \\
\text { entrepreneur_48 }\end{array}$ & $\begin{array}{l}\text { TMT } \\
\text { Member }\end{array}$ & $\begin{array}{l}\text { Nonprofit / For- } \\
\text { profit }\end{array}$ & $\begin{array}{l}\text { Food / } \\
\text { Beverage }\end{array}$ & $\begin{array}{l}\text { Faith-based } \\
\text { organization focused } \\
\text { on promoting } \\
\text { ecumenism; own } \\
\text { social enterprise } \\
\text { (bottled-water } \\
\text { company) }\end{array}$ \\
\hline $\begin{array}{l}\text { Social } \\
\text { entrepreneur_15 }\end{array}$ & $\begin{array}{l}\text { TMT } \\
\text { member }\end{array}$ & For-profit & Food & $\begin{array}{l}\text { Socially-conscious } \\
\text { retail grocer }\end{array}$ \\
\hline $\begin{array}{l}\text { Social } \\
\text { entrepreneur_5 }\end{array}$ & Founder/CEO & For-profit & Health Care & $\begin{array}{l}\text { Online platform that } \\
\text { improves medical } \\
\text { equipment donations } \\
\text { in the developing } \\
\text { world }\end{array}$ \\
\hline $\begin{array}{l}\text { Social } \\
\text { entrepreneur_6 }\end{array}$ & $\begin{array}{l}\text { TMT } \\
\text { member }\end{array}$ & For-profit & Advertising & $\begin{array}{l}\text { Create signage for } \\
\text { causes }\end{array}$ \\
\hline $\begin{array}{l}\text { Social } \\
\text { entrepreneur_20 }\end{array}$ & $\begin{array}{l}\text { Founder / } \\
\text { CEO }\end{array}$ & For-profit & $\begin{array}{l}\text { Advertising / } \\
\text { Marketing }\end{array}$ & $\begin{array}{l}\text { Production company } \\
\text { with social-good } \\
\text { focus. }\end{array}$ \\
\hline $\begin{array}{l}\text { Social } \\
\text { entrepreneur_7 }\end{array}$ & Founder & For-profit & Web Design & $\begin{array}{l}\text { Create websites for } \\
\text { causes, charities, } \\
\text { nonprofits }\end{array}$ \\
\hline $\begin{array}{l}\text { Social } \\
\text { entrepreneur_8 }\end{array}$ & Co-Founder & For-profit & $\begin{array}{l}\text { Youth } \\
\text { Outreach }\end{array}$ & $\begin{array}{l}\text { Summer camp that } \\
\text { teaches social } \\
\text { innovation }\end{array}$ \\
\hline $\begin{array}{l}\text { Social } \\
\text { entrepreneur_28 }\end{array}$ & $\begin{array}{l}\text { Founder / } \\
\text { Executive } \\
\text { Director }\end{array}$ & Nonprofit & $\begin{array}{l}\text { Youth } \\
\text { Outreach }\end{array}$ & $\begin{array}{l}\text { Development } \\
\text { program using } \\
\text { sustainable } \\
\text { agriculture to target } \\
\text { at-risk youth }\end{array}$ \\
\hline
\end{tabular}


TABLE 1 (cont.)

\begin{tabular}{|c|c|c|c|c|}
\hline $\begin{array}{l}\text { Social } \\
\text { entrepreneur_12 }\end{array}$ & Founder/CEO & For-profit & Firearms & $\begin{array}{l}\text { Socially- and } \\
\text { environmentally- } \\
\text { friendly weapons } \\
\text { producers }\end{array}$ \\
\hline $\begin{array}{l}\text { Social } \\
\text { entrepreneur_13 }\end{array}$ & $\begin{array}{l}\text { Co- } \\
\text { founder/CEO }\end{array}$ & For-profit & Consulting & $\begin{array}{l}\text { Social media } \\
\text { fundraising }\end{array}$ \\
\hline $\begin{array}{l}\text { Social } \\
\text { entrepreneur_14 }\end{array}$ & $\begin{array}{l}\text { Co-founder/ } \\
\text { CMO }\end{array}$ & For-profit & Consulting & $\begin{array}{l}\text { Social media } \\
\text { fundraising }\end{array}$ \\
\hline $\begin{array}{l}\text { Social } \\
\text { entrepreneur_18 }\end{array}$ & $\begin{array}{l}\text { Co- } \\
\text { founder/CEO }\end{array}$ & For-profit & $\begin{array}{l}\text { Consumer } \\
\text { Software }\end{array}$ & $\begin{array}{l}\text { Child safety on the } \\
\text { Internet }\end{array}$ \\
\hline $\begin{array}{l}\text { Social } \\
\text { entrepreneur_21 }\end{array}$ & $\begin{array}{l}\text { Founder / } \\
\text { CEO }\end{array}$ & For-profit & Online Giving & $\begin{array}{l}\text { Social-good } \\
\text { fundraising }\end{array}$ \\
\hline $\begin{array}{l}\text { Social } \\
\text { entrepreneur_22 }\end{array}$ & $\begin{array}{l}\text { Co-founder / } \\
\text { CEO }\end{array}$ & Nonprofit & Online Giving & $\begin{array}{l}\text { Automatic micro- } \\
\text { donations }\end{array}$ \\
\hline $\begin{array}{l}\text { Social } \\
\text { entrepreneur_23 }\end{array}$ & Founder & Nonprofit & Job Training & $\begin{array}{l}\text { Café offering } \\
\text { culinary job training } \\
\text { for low income } \\
\text { adults }\end{array}$ \\
\hline $\begin{array}{l}\text { Social } \\
\text { entrepreneur_24 }\end{array}$ & $\begin{array}{l}\text { Founder/ } \\
\text { President }\end{array}$ & Nonprofit & Job Training & $\begin{array}{l}\text { Cultural center } \\
\text { providing training } \\
\text { and vocational } \\
\text { mentoring to } \\
\text { disadvantaged, } \\
\text { disabled, and } \\
\text { underemployed } \\
\text { persons }\end{array}$ \\
\hline $\begin{array}{l}\text { Social } \\
\text { entrepreneur_27 }\end{array}$ & Co-founder & Nonprofit & Job Training & $\begin{array}{l}\text { Teaching } \\
\text { construction skills to } \\
\text { women. }\end{array}$ \\
\hline
\end{tabular}


TABLE 1 (cont.)

\begin{tabular}{|c|c|c|c|c|}
\hline $\begin{array}{l}\text { Social } \\
\text { entrepreneur_32 }\end{array}$ & Founder & Nonprofit & Job Training & $\begin{array}{l}\text { Provide culinary } \\
\text { skills to at-risk } \\
\text { youth }\end{array}$ \\
\hline $\begin{array}{l}\text { Social } \\
\text { entrepreneur_33 }\end{array}$ & $\begin{array}{l}\text { Founder / } \\
\text { Executive } \\
\text { director }\end{array}$ & Nonprofit & $\begin{array}{l}\text { Job Training / } \\
\text { Enrichment }\end{array}$ & $\begin{array}{l}\text { Provide English } \\
\text { training and } \\
\text { education to non- } \\
\text { native-speaking } \\
\text { workers }\end{array}$ \\
\hline $\begin{array}{l}\text { Social } \\
\text { entrepreneur_35 }\end{array}$ & Co-Director & Nonprofit & $\begin{array}{l}\text { Job Training / } \\
\text { Enrichment }\end{array}$ & $\begin{array}{l}\text { Employment } \\
\text { opportunities for the } \\
\text { homeless }\end{array}$ \\
\hline $\begin{array}{l}\text { Social } \\
\text { entrepreneur_36 }\end{array}$ & Co-Director & Nonprofit & $\begin{array}{l}\text { Job Training / } \\
\text { Enrichment }\end{array}$ & $\begin{array}{l}\text { Employment } \\
\text { opportunities for the } \\
\text { homeless }\end{array}$ \\
\hline $\begin{array}{l}\text { Social } \\
\text { entrepreneur_43 }\end{array}$ & $\begin{array}{l}\text { TMT } \\
\text { Member }\end{array}$ & For-profit & $\begin{array}{l}\text { Job Training / } \\
\text { Employment }\end{array}$ & $\begin{array}{l}\text { Provide job training } \\
\text { for individuals with } \\
\text { mental disabilities }\end{array}$ \\
\hline $\begin{array}{l}\text { Social } \\
\text { entrepreneur_25 }\end{array}$ & $\begin{array}{l}\text { TMT } \\
\text { Member } \\
(\mathrm{CFO})\end{array}$ & Nonprofit & $\begin{array}{l}\text { Economic } \\
\text { Development }\end{array}$ & $\begin{array}{l}\text { Provide innovative } \\
\text { youth outreach } \\
\text { programs, shelters, } \\
\text { and employment; } \\
\text { operate several } \\
\text { social enterprises }\end{array}$ \\
\hline $\begin{array}{l}\text { Social } \\
\text { entrepreneur_34 }\end{array}$ & $\begin{array}{l}\text { Founder / } \\
\text { CEO }\end{array}$ & Nonprofit & $\begin{array}{l}\text { Economic } \\
\text { Development }\end{array}$ & $\begin{array}{l}\text { Community } \\
\text { Development } \\
\text { Corporation focused } \\
\text { on economic } \\
\text { development in } \\
\text { underserved } \\
\text { communities. }\end{array}$ \\
\hline
\end{tabular}


TABLE 1 (cont.)

\begin{tabular}{|c|c|c|c|c|}
\hline $\begin{array}{l}\text { Social } \\
\text { entrepreneur_45 }\end{array}$ & $\begin{array}{l}\text { Founder / } \\
\text { Executive } \\
\text { Director }\end{array}$ & Nonprofit & $\begin{array}{l}\text { Economic } \\
\text { Development }\end{array}$ & $\begin{array}{l}\text { Faith-based } \\
\text { organization that } \\
\text { provides educational } \\
\text { programs in the } \\
\text { developing world; } \\
\text { owns a social } \\
\text { enterprise (coffee } \\
\text { shop) } \\
\text { (emerging } \\
\text { economies) }\end{array}$ \\
\hline $\begin{array}{l}\text { Social } \\
\text { entrepreneur_49 }\end{array}$ & $\begin{array}{l}\text { Founder / } \\
\text { CEO }\end{array}$ & For-profit & $\begin{array}{l}\text { Economic } \\
\text { Development }\end{array}$ & $\begin{array}{l}\text { Provide clean-water } \\
\text { program in the } \\
\text { developing world }\end{array}$ \\
\hline $\begin{array}{l}\text { Social } \\
\text { entrepreneur_50 }\end{array}$ & Co-founder & Nonprofit & $\begin{array}{l}\text { Economic } \\
\text { Development / } \\
\text { Online } \\
\text { Fundraising }\end{array}$ & $\begin{array}{l}\text { Provide an online } \\
\text { platform to increase } \\
\text { investments in social } \\
\text { enterprises around } \\
\text { the world }\end{array}$ \\
\hline $\begin{array}{l}\text { Social } \\
\text { entrepreneur_41 }\end{array}$ & $\begin{array}{l}\text { Founder / } \\
\text { Executive } \\
\text { Director }\end{array}$ & Nonprofit & Microfinance & $\begin{array}{l}\text { Provide } \\
\text { opportunities for } \\
\text { women in poverty } \\
\text { through microcredit, } \\
\text { entrepreneurship, } \\
\text { and training }\end{array}$ \\
\hline $\begin{array}{l}\text { Social } \\
\text { entrepreneur_26 }\end{array}$ & $\begin{array}{l}\text { Founder / } \\
\text { CEO }\end{array}$ & For-profit & $\begin{array}{l}\text { Nonprofit } \\
\text { Fundraising }\end{array}$ & $\begin{array}{l}\text { Hotel booking } \\
\text { engine as } \\
\text { mechanism for } \\
\text { nonprofit } \\
\text { fundraising }\end{array}$ \\
\hline $\begin{array}{l}\text { Social } \\
\text { entrepreneur_39 }\end{array}$ & $\begin{array}{l}\text { TMT } \\
\text { Member }\end{array}$ & Nonprofit & $\begin{array}{l}\text { Discount } \\
\text { Consumer } \\
\text { Goods }\end{array}$ & $\begin{array}{l}\text { Help individuals } \\
\text { with barriers to } \\
\text { employment enter } \\
\text { the workforce world }\end{array}$ \\
\hline
\end{tabular}


TABLE 1 (cont.)

\begin{tabular}{|c|c|c|c|c|}
\hline $\begin{array}{l}\text { Social } \\
\text { entrepreneur_29 }\end{array}$ & $\begin{array}{l}\text { Director of } \\
\text { Social } \\
\text { Enterprises }\end{array}$ & Nonprofit & $\begin{array}{l}\text { Faith-Based } \\
\text { Philanthropy }\end{array}$ & $\begin{array}{l}\text { Traditional faith- } \\
\text { based nonprofit } \\
\text { providing a variety } \\
\text { of social services to } \\
\text { those in need; owns } \\
\text { two social } \\
\text { enterprises }\end{array}$ \\
\hline $\begin{array}{l}\text { Social } \\
\text { entrepreneur_31 }\end{array}$ & Director & $\begin{array}{l}\text { For-profit } \\
\text { (subsidiary) }\end{array}$ & B2B Services & $\begin{array}{l}\text { Translation services } \\
\text { for businesses; } \\
\text { owned by traditional } \\
\text { nonprofit. }\end{array}$ \\
\hline $\begin{array}{l}\text { Social } \\
\text { entrepreneur_37 }\end{array}$ & $\begin{array}{l}\text { Director of } \\
\text { Social } \\
\text { Enterprise }\end{array}$ & Nonprofit & Social services & $\begin{array}{l}\text { Traditional social } \\
\text { service organization } \\
\text { providing training, } \\
\text { education, support to } \\
\text { at-risk youth; own } \\
\text { social enterprise. }\end{array}$ \\
\hline $\begin{array}{l}\text { Social } \\
\text { entrepreneur_38 }\end{array}$ & Director & $\begin{array}{l}\text { For-profit } \\
\text { (subsidiary) }\end{array}$ & Social-services & $\begin{array}{l}\text { Event space that } \\
\text { employs at-risk } \\
\text { youth; owned by } \\
\text { traditional nonprofit } \\
\text { organization. }\end{array}$ \\
\hline $\begin{array}{l}\text { Social } \\
\text { entrepreneur_40 }\end{array}$ & $\begin{array}{l}\text { Director of } \\
\text { Social } \\
\text { Enterprise }\end{array}$ & Nonprofit & $\begin{array}{l}\text { Social } \\
\text { Services }\end{array}$ & $\begin{array}{l}\text { Traditional social } \\
\text { service organization } \\
\text { focused on } \\
\text { empowering women } \\
\text { through child- } \\
\text { services and } \\
\text { residential-services } \\
\text { programs; operate } \\
\text { two social } \\
\text { enterprises }\end{array}$ \\
\hline
\end{tabular}


TABLE 1 (cont.)

\begin{tabular}{|l|l|l|l|l|}
\hline $\begin{array}{l}\text { Social } \\
\text { entrepreneur_42 }\end{array}$ & $\begin{array}{l}\text { TMT } \\
\text { Member }\end{array}$ & Nonprofit & Social services & $\begin{array}{l}\text { Provide affordable } \\
\text { housing and support } \\
\text { services for } \\
\text { thousands of low- } \\
\text { income families and } \\
\text { individuals, } \\
\text { empowering them } \\
\text { with the tools they } \\
\text { need to succeed }\end{array}$ \\
\hline
\end{tabular}

The single informant data of Study 1 was appropriately structured for creating a typology. However it was not well-suited for making comparisons across social enterprises and for understanding how differences in narrative use between social enterprises correspond with differences in funding success. Study 2, which utilized a multi-case method, was conducted to address these issues.

\section{Study 2}

In Study 2 I focused on eight technology-focused social enterprises that were not part of the pilot study or Study 1 (Table 2). Five of these cases received external financial investment and were thus classified as funding "successes" and three did not. For all social enterprises, funding attempts were either contemporaneous to the study or had occurred within the recent history of the firm. This allowed the study to incorporate both retrospective and real-time data. Incorporating both forms of data improved the likelihood that informants were able to remember the events that transpired and could do so accurately. 
In each of the eight cases, informants included members of the founding team, executive team, and board of directors. Interviews revealed that seeking external investment was an activity engaged in by only a few individuals at each firm. Therefore the choice of informants at each social enterprise focused on the few key managers who were actively involved in fundraising. Access to each social enterprise was obtained through the organization's CEO (who was often one of the founders). The initial contact then helped to identify other members of the enterprise who had been involved in fundraising and made introductions to the firms' investors and board members. Other informants were identified using "snowball" sampling in each successive interview. Additional investors, and particularly funders choosing not to invest in an organization, were identified through mentions in media articles and organizational documents and were contacted by "cold-calling". 
TABLE 2:

DESCRIPTION OF CASES

\begin{tabular}{|c|c|c|c|c|c|c|}
\hline COMPANY & FOCUS & $\begin{array}{c}\text { YEAR } \\
\text { LAUNCHED; } \\
\text { STAGE OF } \\
\text { DEVELOPMENT }\end{array}$ & OUTCOME & $\begin{array}{l}\text { FUNDING } \\
\text { SOURCE }\end{array}$ & $\begin{array}{l}\text { FUNDING } \\
\text { ROUNDS }\end{array}$ & $\begin{array}{l}\text { INTERVIEWS; } \\
\text { MEDIA } \\
\text { ARTICLES \& } \\
\text { MEDIA } \\
\text { INTERVIEWS }\end{array}$ \\
\hline Alpha & $\begin{array}{l}\text { Social service } \\
\text { efficiency } \\
\text { (Volunteer } \\
\text { management) }\end{array}$ & $\begin{array}{l}2009 \\
\text { Post-Revenue }\end{array}$ & $\begin{array}{l}\text { Funded } \\
\text { Amount }= \\
\$ 2.2 \mathrm{M} \\
\$ 760 \mathrm{~K} \text { seed; } \\
\$ 1.5 \mathrm{M} \\
\text { Series-A }\end{array}$ & VC; Angel & 2 & $6 ; 28$ \\
\hline Lambda & $\begin{array}{l}\text { Social service } \\
\text { efficiency } \\
\text { (Service } \\
\text { delivery) }\end{array}$ & $\begin{array}{l}2010 \\
\text { Post-Revenue }\end{array}$ & $\begin{array}{l}\text { Funded } \\
\text { Amount = } \\
\$ 150 \mathrm{~K}\end{array}$ & Angel & 1 & $7 ; 18$ \\
\hline Beta & $\begin{array}{l}\text { Nonprofit } \\
\text { fundraising }\end{array}$ & $\begin{array}{l}2010 \\
\text { Post-Revenue }\end{array}$ & $\begin{array}{l}\text { Funded } \\
\begin{array}{l}\text { Amount }= \\
\$ 1.6 \mathrm{M}\end{array} \\
\begin{array}{l}\$ 500 \mathrm{~K} \text { seed; } \\
\$ 1.1 \mathrm{M} \\
\text { Series-A }\end{array}\end{array}$ & Angel & 2 & $2 ; 29$ \\
\hline Rho & $\begin{array}{l}\text { Nonprofit } \\
\text { fundraising }\end{array}$ & $\begin{array}{l}2011 \\
\text { Post-Revenue }\end{array}$ & No funding & & & $3 ; 16$ \\
\hline
\end{tabular}


TABLE 2 (cont.)

\begin{tabular}{|c|c|c|c|c|c|c|}
\hline Epsilon & $\begin{array}{l}\text { Social media } \\
\text { fundraising }\end{array}$ & $\begin{array}{l}2010 \\
\text { Post-Revenue }\end{array}$ & $\begin{array}{l}\text { Funded } \\
\text { Amount }= \\
\$ 2 \mathrm{M} \\
(\$ 500 \mathrm{~K} \\
\text { angel; } \$ 1.5 \mathrm{M} \\
\mathrm{PE})\end{array}$ & $\begin{array}{l}\text { Angel; } \\
\text { Private } \\
\text { equity }\end{array}$ & 3 & $4 ; 25$ \\
\hline Omega & $\begin{array}{l}\text { Social media } \\
\text { fundraising }\end{array}$ & $\begin{array}{l}2010 \\
\text { Post-Revenue }\end{array}$ & No funding & & & $7 ; 23$ \\
\hline Gamma & $\begin{array}{l}\text { Online } \\
\text { marketing }\end{array}$ & $\begin{array}{l}2011 \\
\text { Post-Revenue }\end{array}$ & $\begin{array}{l}\text { Funded } \\
\text { Amount } \\
\text { undisclosed }\end{array}$ & Angel & 1 & $3 ; 34$ \\
\hline Sigma & $\begin{array}{l}\text { Online } \\
\text { Marketing }\end{array}$ & $\begin{array}{l}2011 \\
\text { Post-Revenue }\end{array}$ & No funding & & & $2 ; 15$ \\
\hline & & & & & Total & $34 ; 18$ \\
\hline
\end{tabular}

\section{Data Collection}

As described, Study 1 data was collected from interviews with 75 individuals involved in the social enterprise sector. Interviews were semi-structured, lasting approximately an hour in duration, and included a combination of closed- and openended questions. Interviewees were first asked to provide background information. Social entrepreneurs were then asked to describe the founding of their current venture. Each entrepreneur was then asked about their resource acquisition attempts (seeking both financial and nonfinancial resources) and about prospective sources of funding (i.e. what resource acquisition attempts they had planned). In contrast, interviews with resource providers focused on recent funding decisions and on the criteria used to choose between 
investments. In general, interviews in Study 1 followed a more open-ended format than in Study 2 and focused on the expertise of the informant and their experiences with social enterprise resource acquisition.

In Study 2 I collected data from technology-focused social enterprises. This subset of social ventures was chosen because, following prior work (e.g. Madill, Haines, \& Riding, 2005), tech-ventures are more likely than other types of entrepreneurial ventures to pursue external investment. Thus there was reason to believe that resource acquisition activity would be prevalent in this set of firms and that most of the founders would have at least considered pursuing external investment.

I selected the eight specific social enterprises based on theoretical and pragmatic considerations (Eisenhardt, 1989; Yin, 1984). First, to be considered for inclusion in the study, a venture had to fall under the general definition of social enterprise (i.e. an organization targeting a social problem using business methods). It also had to possess the three, more specific, characteristics of a social enterprise (i.e. addressing a social problem, creating economic and social value, doing so in an innovative way; Martin \& Osberg, 2007, Dees, 1998). Second, because of the focus on resource acquisition, I chose social enterprises that allowed for access to real-time data collection and observation of resource acquisition attempts. Thus, I targeted social ventures that were active in seeking funding (i.e. were currently, or very recently, engaged in resource acquisition attempts), rather than social enterprises whose funding sources were established. Moreover, I also avoided very early-stage start-ups, which had yet to make (significant) attempts to acquire funding and resources. Finally, as described, I chose technology-focused social 
enterprises because, as with traditional start-ups, tech-focused ventures are typically more active in seeking external investment than new ventures operating in other industries. Table 3 depicts how each social enterprise's funding coincided with the timeline of data collection. The table shows that all of the "successful" cases received funding during the period of data collection and only two rounds of funding (Alpha's and Epsilon's seed rounds) occurred outside the data collection window.

TABLE 3:

TIMELINE OF FUNDING AND DATA COLLECTION

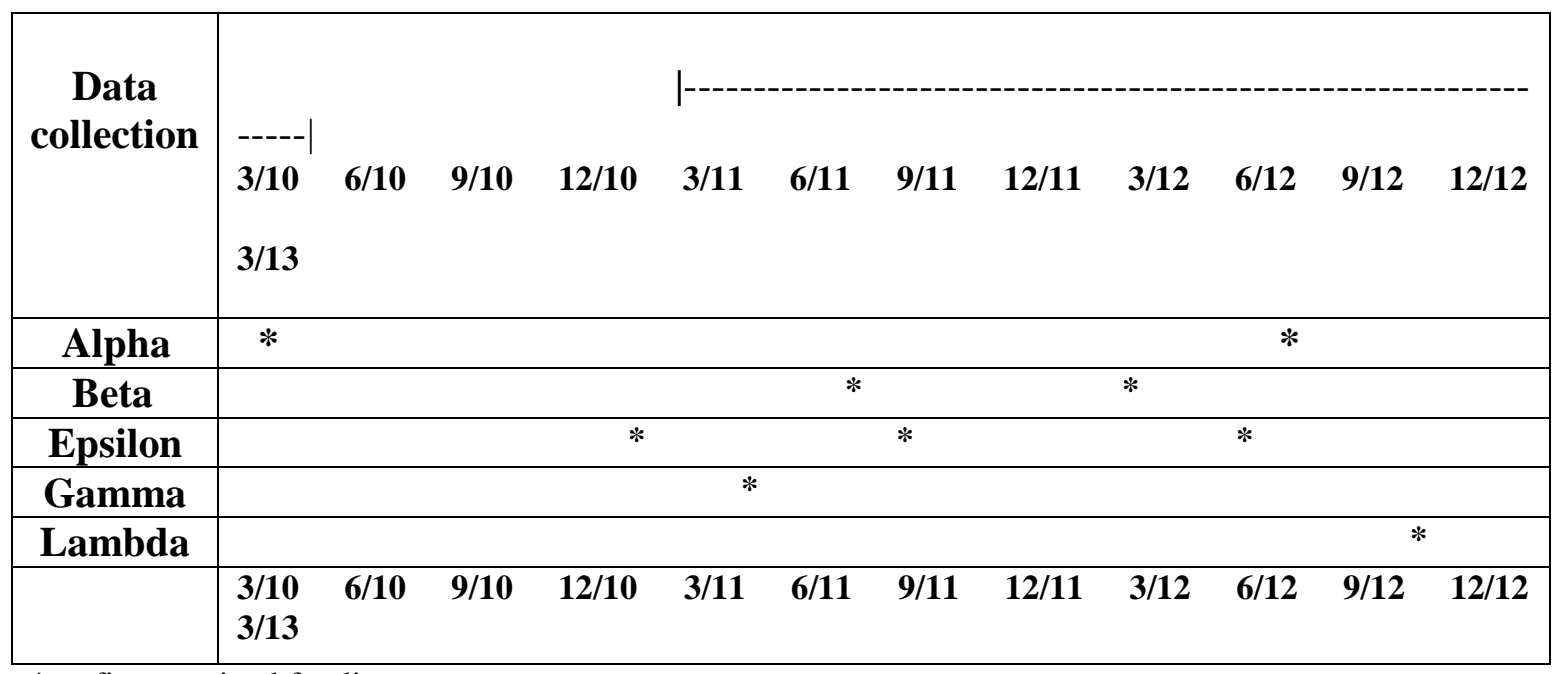

* = firm received funding

For the social enterprises, I interviewed founders, members of the executive team, and board members. I also interviewed the ventures' investors and, when possible, funders that evaluated the venture but decided not to invest. I used semi-structured interviews that utilized a combination of closed- and open-ended questions. Interviews took place in person or over the phone. Interview sessions lasted between 45 and 90 minutes. During the interview, informants were provided with a very general description of the topic of the study (e.g. "social enterprise fundraising"). Moreover, I offered 
informants confidentiality and the option for pseudonyms to be used to ensure their anonymity and the anonymity of their social enterprise. I also advised informants that the information they provided would not be communicated between interviews to other informants.

Separate interview guides were developed for social entrepreneurs and investors (an example is included in Appendix E). The interview guides for social entrepreneurs began by asking for background information on the informant and the social enterprise. I then asked a series of questions about the chronology of the company. I emphasized their fundraising and investment-seeking activities. Informants were asked to relate the details of their funding attempts. These questions were supplemented through probing and clarifying questions (Santos \& Eisenhardt, 2009). Questions concentrated on facts and events rather than on respondents' interpretations (Eisenhardt, 1989). I emphasized resource acquisition attempts made in the previous 18 months since recollections are relatively stable for this time period (Huber \& Power, 1985). Finally, entrepreneurs and investors were also asked specific, closed-ended questions (e.g. "On what date did the venture receive its first round of angel investment?")

Interview information was supplemented by several additional sources of data. These data sources contained important information about each firm (e.g. changes in senior management) and their narrative content and use. First, for each firm I collected every media article available - both print-media and web-only content - using databases such as LexisNexis. I also gathered online information about each social enterprise (e.g. all articles and videos contained on their websites, blogs, YouTube channels). In addition, 
using the Internet Archive (www.archive.org), I collected all previous versions of each company's website (and other online materials) dating back to its founding. Third, I collected the firms' external communications, such as press releases (e.g. using PR Newswire). Finally, when possible, I attended and recorded the firms' pitches (or received videos of the pitches from my primary contact).

In addition to the interviews, if clarification was needed, follow-up questions were asked via email. If fundraising was ongoing at the time of the initial interview, subsequent interviews were conducted with the primary informant (e.g. usually the CEO) after a major event, such as the closure of a round of fundraising.

All interviews were recorded using a digital recorder and then transcribed. In total, the three studies contained 121 interviews. These produced approximately 2400 double-spaced pages of transcripts. Table 4 summarizes the data collected for each of the eight cases. 
TABLE 4:

SUMMARY OF DATA

\begin{tabular}{|c|c|c|c|c|c|}
\hline COMPANY & Interviews & $\begin{array}{c}\text { Media } \\
\text { articles / } \\
\text { Interviews }\end{array}$ & $\begin{array}{c}\text { Online } \\
\text { Material } \\
\text { (e.g. } \\
\text { Company } \\
\text { Blog, } \\
\text { YouTube } \\
\text { channel) }\end{array}$ & $\begin{array}{c}\text { External } \\
\text { Communication } \\
\text { Documents }\end{array}$ & $\begin{array}{l}\text { Website } \\
\text { Archives }\end{array}$ \\
\hline Alpha & 6 & 28 & $\mathrm{Y}$ & $\mathrm{Y}$ & 12 \\
\hline Lambda & 7 & 18 & $\bar{Y}$ & $\mathrm{~N}$ & 10 \\
\hline Beta & 2 & 29 & $\bar{Y}$ & $\mathrm{Y}$ & 11 \\
\hline Rho & 3 & 16 & $\bar{Y}$ & $\bar{Y}$ & 6 \\
\hline Epsilon & 4 & 25 & $\bar{Y}$ & $\bar{Y}$ & 12 \\
\hline Omega & 7 & 23 & $\bar{Y}$ & $\mathrm{Y}$ & 11 \\
\hline Gamma & 3 & 34 & $\bar{Y}$ & $\mathrm{Y}$ & 7 \\
\hline Sigma & 2 & 15 & $\bar{Y}$ & $\mathrm{Y}$ & 8 \\
\hline
\end{tabular}

\section{Data Analysis}

Data collected in Study 1 - the 75 interviews with participants in the social enterprise sector - was analyzed using established procedures for inductive, theorybuilding research (Miles \& Huberman, 1994). Specifically, as I documented patterns in 
the data, I constructed tentative theoretical explanations and used the data from each interview to challenge or extend the working theory (e.g. Strauss \& Corbin, 1998; Baker \& Nelson, 2005). During the process of analyzing the data, revising theory, and returning to the data, the typology of social enterprise narratives reported in Chapter 5 emerged.

Study 2 data was analyzed by building cases for the eight social enterprises. Specifically, several data sources (e.g. interviews, media articles, website archives, pitch videos) were synthesized to form a case study for each social enterprise. Each case study followed a similar structure and contained the same information: a history of the social venture, the backgrounds of the founders, the social problem addressed, the business model, and fundraising activities (including information about each resource acquisition attempt and outcome). Case studies averaged 54 double-spaced pages in length and included narrative, selected quotes from informants, tables containing specific firm and fundraising information (e.g. funding dates; amount of each round of investment) and timelines summarizing events.

After constructing the case studies, I began within- and across-case analyses. The goal of within-case analysis was to understand events experienced by the focal social ventures and to develop generalized codes, themes, and theoretical constructs that emerged as being important for resource acquisition (Eisenhardt, 1989). Although there were obvious similarities and differences among cases, to maintain the independence of the replication logic, I did not conduct detailed analysis until all cases were complete.

In contrast, I used across-case analysis to "triangulate and substantiate" emerging constructs (Ravasi \& Phillips, 2011). Cases were treated as a series of experiments, each 
serving to either confirm or disconfirm insights drawn from other cases. I examined if emerging constructs were present across multiple cases and if similar themes emerged in multiple settings (Miles \& Huberman, 1994; Eisenhardt, 1989). In addition, in some instances it was useful to compare pairs of cases to highlight their similarities and differences. I refined emerging constructs and relationships using replication logic (Yin, 1994), revisiting the cases to determine if each demonstrated the same pattern or theme. Finally, tables, charts, and figures were used to facilitate between-case analysis.

The ultimate goal of the analysis phase, and the two studies, was to create a theoretical framework that addressed the guiding research questions and that explained the relationships observed. What emerged from this process was a framework to explain how differences in entrepreneurs' narrative tactics and characteristics are associated with differences in their resource acquisition success. Study 1 demonstrates that social entrepreneurs can construct three narrative-types (personal, social-good, and business) each possessing unique elements. These narrative types serve as the buildings blocks for communication with external stakeholders and particularly investors and the media. Study 2 provides evidence that successful social entrepreneurs used these narratives to engage in two tactics - tailoring and linking - and constructed narratives with a unique characteristic: multiplexity. The next four chapters present the findings that led to the construction of this framework. 


\section{CHAPTER 5:}

\section{WHAT NARRATIVES DO SOCIAL ENTREPRENUERS CONSTRUCT?}

Evidence from a pilot study (Appendix C) suggests that narratives can play a particularly important role in social enterprise funding. However, scholars have not examined the narratives used by social entrepreneurs in acquiring resources. An important first step in understanding narrative-use is the development of a typology of social enterprise narratives. The creation of such a generalized typology can help to map and elucidate what narrative content (e.g. themes and characters) is available to social entrepreneurs. Moreover, narrative content is the focus of the typology because it is arguably the most general characteristic of narratives and the most commonly examined source of similarities and differences (e.g. Georgesen \& Solano, 1999). Other elements of narrative structure (e.g. stylistic features such as differences in syntax, phonetics, grammar, and semantics) were not examined since linguistic analysis was not the focus of the study.

In this chapter, I present evidence from Study 1, the goal of which was to create a typology of social enterprise narratives. Findings suggest that social entrepreneurs can develop and communicate three types of narratives: personal, social-good, and business. It will be argued that these narrative-types and their elements (e.g. characters, themes) serve as the building blocks for the stories entrepreneurs tell about their ventures and for more complex narrative tactics. Thus, the findings in this chapter lay the groundwork for 
subsequent chapters, which examine how these narrative-types are used in resource acquisition $^{11}$.

\section{Personal Narratives}

Findings indicate that social entrepreneurs draw on their lived experiences to construct personal narratives, which are a compilation of the entrepreneurs' experiences, attributes, significant life events, and founding stories. They can be used in communication with multiple stakeholder groups, including investors, the media, customers, and employees. Although the specific details included in these stories are idiosyncratic to each entrepreneur, across the stories there are recurring patterns in the narratives' content (i.e. the characters and themes).

\section{Characters}

The founders of a social enterprise constitute the agents (or "characters") in personal narratives. If firms have multiple founders one is often designated - implicitly or explicitly - as the focal character. As described below, this individual's experiences (e.g. work and non-work experiences, significant life events), attributes (e.g. beliefs, values, motivations), key decisions, and the story of how he or she founded the social enterprise, constitute the main themes of personal narratives. Table 5 provides examples of each theme and sub-theme ${ }^{12}$.

\footnotetext{
${ }^{11}$ This chapter is presented in a manner that is more descriptive than analytical. This corresponds with the chapter's overarching goal: to describe and classify the narratives constructed by social entrepreneurs.

${ }^{12}$ A more comprehensive table is included in Appendix D.
} 
TABLE 5: PERSONAL NARRATIVES

\begin{tabular}{|c|c|}
\hline $\begin{array}{l}\text { Themes (and sub- } \\
\text { themes) }\end{array}$ & Illustrative quote(s) \\
\hline \multicolumn{2}{|l|}{ Prior experiences } \\
\hline Work experiences & $\begin{array}{l}\text { "...I was at one of the largest advertising agencies in Paris, Adverte } \\
\text { Groupe. Having those experiences developed me into the executive I am, } \\
\text { gave me the confidence that I carry myself with and a global mindset so I } \\
\text { can really be the force behind GoodShoes." (Founder/CEO; SE_2) }\end{array}$ \\
\hline Non-work experiences & $\begin{array}{l}\text { "After college I did the normal, like, 'what do you want to do with your } \\
\text { life?' I went to Romania. I volunteered at a group home for disabled } \\
\text { children and young adults." (Founder/CEO; SE_50) }\end{array}$ \\
\hline \multicolumn{2}{|l|}{$\begin{array}{c}\text { Beliefs, Values, and } \\
\text { Motivations }\end{array}$} \\
\hline General & $\begin{array}{l}\text { "Everything we've done is the culmination of what [co-founder] and I } \\
\text { believe in." (Co-Founder; Informant_7) }\end{array}$ \\
\hline Passions & $\begin{array}{l}\text { "So that intersection [between nonprofits and for-profits] is really where } \\
\text { my passion is, and I've had all of my career in both of those areas." } \\
\text { (Founder; SE_4) }\end{array}$ \\
\hline Religious / spiritual beliefs & $\begin{array}{l}\text { "I am a Christian and I felt like God just wouldn't give me this random gift } \\
\text { if I didn't need to do something with it. I was like, well, I always wanted } \\
\text { to start a community development corporation. So why don't I pair the } \\
\text { two of these things together in some way. So I started thinking about how } \\
\text { I could kind of serve the poor with this company." (Founder; SE_32) }\end{array}$ \\
\hline \multicolumn{2}{|l|}{ Events } \\
\hline $\begin{array}{l}\text { Epiphany / "cubicle story" } \\
\text { / work-life integration }\end{array}$ & $\begin{array}{l}\text { "[...] and it's one of those things where you say that and you have an } \\
\text { epiphany and you are like, 'that's it, that's [...] the company'." } \\
\text { (Founder/CEO; SE_20) } \\
\text { "At Apple [...] I was trying to climb the corporate ladder. I was hitting the } \\
\text { ceiling and I was like, 'I have to be here for } 10 \text { years to try and get a } \\
\text { manager title'. I don't want to do that. I'm in a cubicle working } 80 \text { hours } \\
\text { with overtime." (Founder/CEO; SE_20) } \\
\text { "[Theology and work] were very much these different areas of my } \\
\text { thinking and they were little separate compartments. And it finally } \\
\text { dawned on me that there might be a different way." (Founder; SE_3) }\end{array}$ \\
\hline
\end{tabular}




\section{TABLE 5 (cont.)}

\begin{tabular}{|c|c|}
\hline Trigger event & $\begin{array}{l}\text { "Graduated in December '09 and in January, when I was trying to figure } \\
\text { what next entrepreneurial adventure I was going into, the earthquake hit in } \\
\text { Haiti." (Founder; SE_5) }\end{array}$ \\
\hline Social problem exposure & $\begin{array}{l}\text { "Then I went to Peru I talked to women there, I just was attracted to } \\
\text { talking to women in the fields and the kitchens. And every one of those } \\
\text { women said the same thing. They all said, "We need this investment so } \\
\text { that we can take care of our kids." (Founder; SE_41) }\end{array}$ \\
\hline Social enterprise transition & $\begin{array}{l}\text { "About the same time, I started learning about social enterprises }[\ldots] \text { And } \\
{[\mathrm{I}] \text { just felt like the next step for the Community Kitchen was to take it out }} \\
\text { of the food bank into an actual café setting [...]" (Founder; SE_23) }\end{array}$ \\
\hline Struggles / challenges & $\begin{array}{l}\text { "[...] then about a year and a half ago, I became homeless because my } \\
\text { credit card maxed out. So I spent ten months living on a couch }[\ldots] \text { until } \\
\text { when we finally felt comfortable that we had been raising enough capital } \\
{[\ldots] \text { (Founder; SE_50). }}\end{array}$ \\
\hline \multicolumn{2}{|l|}{ Founding story } \\
\hline Founding “journey" & $\begin{array}{l}\text { "I consulted at UNICEF for five weeks and made about } \$ 4,400.00 \text {. We } \\
\text { took that money. We moved it into our account. Flew to Haiti where one } \\
\text { of the partners was starting up a nonprofit program. [...] Then we filled } \\
\text { [boxes] with lumps of coal and we just started selling lumps of coal for } \\
\$ 20.00 \text {. So every box would essentially, } \$ 20.00 \text { would get one stove to a } \\
\text { family in Haiti." (Founder; SE_50) }\end{array}$ \\
\hline $\begin{array}{l}\text { Decision to form as for- } \\
\text { profit, nonprofit, or hybrid }\end{array}$ & $\begin{array}{l}\text { "I was just never interested in being a for-profit. [...] It's just not in my } \\
\text { DNA - it's not in me to generate income." (Founder; SE_32) }\end{array}$ \\
\hline
\end{tabular}

\section{Themes}

Prior work experiences. A prominent theme in personal narratives is the founding social entrepreneur's prior experiences, which tend to fall into two categories: work- and non-work-related experiences. The communication of this information can serves at least two purposes. First, it can signal prestige and help to establish legitimacy (Certo \& Hodge, 2007). For instance, the founder of a social enterprise that imports jewelry from artisans in the developing world describes that he was a top-level executive at a Fortune 500 company and that he was also "at one of the largest advertising agencies 
in Paris". This social enterprise has a particularly complex global supply chain; thus, the founder attempts to convey that past experiences have prepared him for his current venture. As he explains, these experiences "gave me [...] a global mindset so I can really be the force behind GoodShoes (Founder/CEO; SE_2)."

Second, descriptions of prior work experience can also elucidate how entrepreneurs are integrating their business and nonprofit experiences. For example, one founder, describes how he is drawing on his background in "consulting and investment banking" and a "pro bono volunteer stint working with an MFI [micro finance institution] in Africa" to inform his new social enterprise (Founder/CFO; SE_19). By linking these seemingly disparate experiences the entrepreneur is making sense of (and constructing) their life narrative (e.g. McAdams, 2008; Singer, 2004) and creating coherence across their previous identities (Somers, 1994). Indeed, he describes the coherence that social enterprise brings to his autobiographical narrative:

That volunteer stint ended up turning into a leadership role where I led the organization. Then I came back to business school, went back into the corporate world and, always knew I wanted to do something entrepreneurial, and I certainly always had an interest in doing something socially-oriented. It worked out that with this company, I have the opportunity to do both. (Founder/CFO; SE_19)

Moreover, by recounting how they have integrated their prior work experiences, entrepreneurs are also making a case for why social enterprise, which is a blend of business and nonprofit logics, is a natural extension of their prior experiences. For instance, one founder states,

My background was in non-profit work. But my education was in business, an MBA. And I've had an interest in seeing non-profits and businesses align, you know, kind of unifying them and doing things that are also for social good which, to me, is what a social enterprise is all about. (Founder; SE_4) 
The act of communicating about one's prior work experiences can, thus, serve both external (e.g. quality signaling, legitimation) and internal (e.g. sensemaking, identity integration) functions.

Non-work experiences. Social entrepreneurs also can weave their non-work experiences into their personal narratives. Such experiences, which commonly involve some form of volunteerism, are often used to explain how the entrepreneurs were exposed to social problems. One founder, who created a nonprofit that provides a webbased donation platform to support social entrepreneurs in the developing world, explains,

After college I did the normal "what do you want to do with your life?" I went to Romania. I volunteered at a group home for disabled children and young adults. [...] One of the reasons why the kids were in such bad shape was because there was no job, so they often were abused. (Founder/CEO; SE_50)

Communicating these experiences can also be a means of conveying that the social entrepreneur possesses a disposition towards helping others. For instance, one social entrepreneur states, "I was always just a big volunteer. So I was volunteering with lots of different organizations" (TMT member; SE_6). Another founder recounts that he has "been involved in humanitarian work [his] entire life" (Founder/CEO; SE_2). Information about these experiences establishes a history - or "track-record" - of addressing social problems, even if the problems do not include the one directly addressed by their current social enterprise.

Beliefs and Values. In addition to their experiences, social entrepreneurs' attributes also shape their personal narratives. In general, entrepreneurs often communicate that their social enterprise is the embodiment of their individual-level 
beliefs and values. For instance, one founder describes her venture as “. .. the culmination of what [co-founder] and I believe in (Founder; Other_7)" and another states, “... our backgrounds, both of our interests, have really melded into Empower Girls" (Founder; SE_8). Moreover, informants explain that the link between the founders' attributes and the social enterprise is not just important to the entrepreneur but is also fundamental to the business. The founder of a social enterprise that heavily leverages the adoption story of one its founders explains that the organization is an "extension of [my co-founder's] personality and who she is and wants, - that's part of the secret sauce to the DNA of the company itself”' (Founder/CFO; SE_19).

Beyond a general connection between social entrepreneurs' attributes and their ventures, one of the most salient, specific attributes described as linking founders to their venture is entrepreneurs' passion (Cardon, Wincent, Singh, Drnovsek, 2009). In particular, such passion is directed at two common targets: solving a particular social problem and promoting social enterprise as a (preferred) alternative to nonprofits or traditional, for-profit business. One founder's passion centers on alleviating poverty.

And that's really where my passion lies is around the issue of poverty. I'm firmly convinced that it doesn't have to be so complex. It's a complex issue, but it's not an unsolvable issue. (Founder; SE_23)

In contrast, many social entrepreneurs' personal narratives are tied to passion for social enterprise itself. For example, one entrepreneur states, "that intersection [between nonprofits and for-profits] is really where my passion is, and I've had all of my career in both of those areas" (Founder; SE_4). Cardon, Sudek, and Mitteness (2009) find that entrepreneurial passion can influence investors' evaluations of a venture's funding 
potential. This suggests that the passion social entrepreneurs' communicate through their personal narratives can have important implications.

Another recurring theme across personal narratives is the espoused connection between social entrepreneurs' religious and spiritual beliefs and their venture. For instance, some founders cite their religious and spiritual convictions as the impetus for addressing a particular social problem and, thus, for founding their social enterprise (e.g. "I am a Christian and I felt like God wouldn't give me this random gift [culinary aptitude] if I didn't need to do something with it. [...] So I started thinking about how I could serve the poor with this company." (Founder; SE_32). Others describe a more complex relationship between spirituality and social enterprise. Specifically, many personal narratives express the idea that social enterprise is unique in that it allows entrepreneurs to express their spirituality in their work.

When Jesus was talking in Luke, saying, “...bring Good News to the poor,
freedom to the captives, sight to the blind, healing to the sick,”... [I thought]
maybe I can have all the parts of me, the energy, time, network, resources,
creativity, imagination - if I can put all that into a business that actually is going
to move the needle for people who are in extreme poverty, or who have been
disadvantaged and try to somehow get at that, what Jesus is talking about, Good
News to the poor - you know, dignity through honest work and being able to
pay their own bills and put food on the table and pay rent or the mortgage or
whatever. (Founder; SE_3)

By communicating that social enterprise functions as an "integrator" of their spiritual beliefs and professional lives, entrepreneurs have a different means of reinforcing their deep-seated passion for a social problem and commitment to their venture. (A more detailed discussion of how entrepreneurs' communicate about social enterprise and worklife integration in their personal narratives is found below.) 
Significant events. Social entrepreneurs' personal narratives often revolve around singular events, which alter the course of their work and personal lives and set them on the path of social entrepreneurship. These events serve as the "turning point" (Schiffrin, 2003) or, more generally, the "complicating action" (Labov, 1972) of the story. How events influence entrepreneurs and their ventures is unique to the individual; such events can, however, be organized into four, generic subthemes.

Epiphany moments. Social entrepreneurs' personal narratives often contain the story of a specific moment when they realized either (a) that they should found a social venture or (b) that social enterprise could provide a means for addressing a particular social problem. For instance, in describing a period in his life when he had a clear passion to help others but did not know how to execute on that passion, one founder recounts,

So I said okay, I want to be able to reach people's hearts and minds. I want to touch people's core and it's one of those things where you say that and you have an epiphany and you are like, that's it, that's [...] the company. (Founder/CEO; SE_20)

A sub-set of these narratives, which is particularly prevalent, can be termed "cubicle moments". These stories possess a common script and setting. The entrepreneur describes being at work in a large corporation and realizing, often quite suddenly, that they no longer find meaning in their work.

At Apple ... I was trying to climb the corporate ladder. I was hitting the ceiling and I was like, 'I have to be here for 10 years to try and get a manager title'. I don't want to do that. I'm in a cubicle working 80 hours with overtime. What's the real purpose here? What if I die tomorrow - I got all morbid with myself if I die tomorrow what is it all going to amount to? (Founder; SE_20) 
This realization is often accompanied by a description of "existential search" (Klaassen \& Marvin, 2002). For example, one entrepreneur explains, "I was like 'what am I doing [with my life], what do I want to do, what do I love? (Founder; SE_27).”

In some cases, however, the "cubicle moment" is not communicated as happening as suddenly or as explicitly as the previous examples. Rather, it is characterized by an unspecific anomie (Merton, 1938). One founder communicates it this way, "[Even though] I was doing really well, it just seemed like I didn't have a meaning for myself. It was very disconnected; I would go there, work hard, and come back home, and just my values ... there was no value connection" (Founder; SE_1).

Trigger events. Other significant events, not tied to "cubicle stories", can also serve as the turning point in the arc of a personal narrative. Such events include lifechanging encounters with high profile social entrepreneur (e.g. Muhammad Yunus, Blake Mycoskie), natural disasters (e.g. the Haiti Earthquake), national tragedy (e.g. 9/11), or personal crisis (e.g. death of a close family member). Entrepreneurs point to these events as what "triggered" (e.g. Founder; SE_36) their motivation to found a social enterprise.

Social problem exposure. Although it is not necessarily associated with a singular event or interaction, a significant portion of social entrepreneurs' personal narratives are devoted to communicating how they were exposed to the specific societal problem that has become the focus of their venture. For instance, one founder, whose social enterprise employs refugee women from war-torn nations and uses t-shirts destined for landfills to create designer clothing, explains how she became aware of the refugee problem.

[I] started out doing a lot of orphan work overseas. And, on one of my trips in Africa, in Uganda, all the attention was on Northern Uganda and the rebels and 
everything. I was with a group of women who had been displaced because of all of the warfare. And it was about 200 women. All of them, for the most part, had been raped by the rebels and had been banned from their families because a lot ended up with children because of the rape. And a lot of them were HIV positive. Just some of the, the most horrific human rights violations that you can imagine. And I was sitting with these women and looking at them. For me, it was just one of those pivotal kind of life moments, looking at those women, and me being a woman, and looking at their moms and sisters and grandmas and daughters and just realizing that ... and their spirit, you know, of being able to keep moving on inspired me. It just inspired me and it called to me that we all needed to care for each other, for one another. So, I kept thinking at the time, "If that was me, I hope someone would say, 'This isn't acceptable'." So, that motivated me personally. (Founder; SE_3)

Entrepreneurs can become exposed to a social problem in a large number of ways (e.g. mission trip, travel, volunteering, family experience). The settings of such stories, however, share a commonality: virtually all describe the social entrepreneur entering the environment of the group affected by the social problem. For example, one founder, a clothing manufacturer who provides fair wages and resources for cotton farmers and garment workers in India and Haiti, explained that he was aware that poverty was an issue in these countries in an abstract sense, but that he was only truly exposed to the problem after visiting the area.

Just walking out of my hotel while I was there [Calcutta, India], and walking down the street, you're just bombarded with smell - all this cacophony of smells - putrid waste, human waste, and others - and then there's this other kind of sweet smell that I discovered later is a mix of burning trash and rotting food, but it ends up being kind of a sweet smell, and something that I remember. And when I got back from India I went to Haiti, and I smelled the same smell. [...] My motivation in all this, it really came out of trying to reconcile if I want to be part of a better story. (Founder; SE_4)

Recounting such stories can serve several purposes. First, they represent entrepreneurs' efforts to unify and make sense of their life experiences (Cohen \& Mallon, 2001). This aids them in understanding their motivations for founding their social venture. Second, as the quotation above illustrates, they often contain vivid descriptions with concrete 
imagery and details (Nisbett \& Ross, 1980). These characteristics can increase the likelihood that audiences will engage in narrative "transportation" (Green \& Brock, 2000; Escalas, 2007) - i.e. the immersive state in which one mentally simulates being in the world described in a narrative. Since transportation can increase an audience's empathy (Green, Brock, \& Kaufman, 2004) and a narrative's overall persuasiveness (Escalas, 2004), social entrepreneurs that tell such personal stories may be able to influence an audience's support for a social problem. Third, these stories can also convey that the social entrepreneur has personal experience with the problems (e.g. through missionary or nonprofit work), which may improve credibility with certain audiences.

Social enterprise exposure. Entrepreneurs' personal narratives often include not only how they came to be exposed to a particular problem, but also how they learned about social enterprise itself. For instance, the founder of a restaurant providing culinary training to at-risk youth and low-income adults describes how she first became aware of the social enterprise model.

\footnotetext{
About the same time, I started learning about social enterprises and how DeLancey Street Foundation and Fair Start and others have been so successful around the country. And [I] just felt like the next step for the Community Kitchen was to take it out of the food bank into an actual café setting where students could really get some hands on learning around not only cooking skills, but customer services skills. (Founder; SE_23)
}

Although social entrepreneurs often engage in more detailed descriptions of why social enterprise is the preferred method of addressing a particular problem (described below), by drawing attention to predecessors that have found success, such narratives can help to communicate that social enterprise is a legitimate organizational form (Padolny \& Page, 1998). 
Struggles / Challenges. In most stories, the main character (i.e. protagonist) takes part in a "journey" in which they must overcome an obstacle (Smith, 1997). Indeed some theorists argue that obstacles (either concrete or metaphorical) are so fundamental to the narrative form that they must be present for communication to be classified as a story (Altman, 2008). Obstacles are critical story-elements for several reasons. First, they create a sense of suspense ("will a character be able to overcome?"), which helps to maintain audience interest and attention (Brewer \& Lichtenstein, 1981). Second, obstacles give audiences an experience with which they can identify and empathize (Keen, 2006). Finally, they often result in the transformation in the protagonist, or his or her circumstances, which is the raison d'etre of the narrative.

Social entrepreneurs' personal narratives also include obstacles. They are often struggles or challenges that occur in the entrepreneurs' past, which they had to overcome in order to found their venture, or obstacles arising during the creation of their business. For instance, one founder tells the story of how it took much longer than expected for her venture to become financially sustainable. Moreover, she had so much of her own money invested in the business that there came a point when she could no longer pay her rent.

So we didn't seek salaries for over a year. So then about a year and a half ago, I became homeless because my credit card maxed out. So I spent ten months living on a couch $[\ldots]$ until when we finally felt comfortable that we had been raising enough capital that we could take some money to cover our costs. (Founder; SE_50).

The founder was at first reluctant to publicize the narrative for fear that her homelessness would make the venture seem "wild and unsustainable". However, a high-profile media outlet eventually uncovered the story. Subsequent reactions by other media outlets were so favorable that the founder's homelessness is now a focal point of her personal 
narrative. (The interaction between the media and social entrepreneurs' storytelling is a phenomenon explored in more detail in the next chapter.)

Founding story. The final collection of themes present in most personal narratives involves the specific events taking place when the venture was founded. Like the "social problem exposure" stories these narratives are often very vivid and contain humorous or unusual details. For example the founder of a pie kitchen that provides job training and financial literacy skills to individuals with extreme barriers to employments (e.g. homeless individuals with criminal histories or disabilities) recounts how her social enterprise was founded.

\begin{abstract}
While in graduate school I was working at Kenmore Records for a little extra cash and for the perks of a record store job. [...] When I heard that my favorite [artist] was coming to do an in-store performance and realized I'd get the chance to meet him, I thought to myself, "I bet he would like a homemade pecan pie." I'm not sure why I thought he'd like pie, but I made a pecan pie and stood in line for the autographs and presented the pie to him and he generously responded by saying, "Thanks for the pie, Erica." A few weeks later [another celebrity] came to the store to do an in-store and my co-workers said that if [other artist] got a pie, then I had to make one for him too. Soon after that it was a coworker's birthday and I brought them a pecan pie. After eating the pie, someone said that I should try and sell them. And, thus, became the Good Pie Kitchen. (Founder; SE_32)
\end{abstract}

Like the previous social entrepreneur's period of homelessness, the media has given a great deal of attention to this story, and particularly the idea that the business was "born out of a pie baked for Lyle Lovett." Even though this story is largely inconsequential to the mission of the business and its operations, it is featured in most media reports about the social enterprise. The entrepreneur, in turn, makes an explicit effort to communicate this story.

Finally, another common element in entrepreneurs' personal narratives, which is related to the founding of the venture, is the decision about what organizational form will 
be used. As described in Chapter 1, a social enterprise can be founded as a for-profit, nonprofit, or hybrid. There are significant structural, legal, and operational differences between each of these forms (Fruchterman, 2011). Moreover, entrepreneurs communicate a wide array of rationales for choosing one form over another. However, the decision is usually presented as having been based on either pragmatic or personal reasons. For example, one founder's decision was pragmatic.

\begin{abstract}
We realized that most people who would be giving to this would want a tax receipt. That was probably the most important factor [in deciding between a forprofit or nonprofit]. We can still probably spin off a social enterprise [i.e. forprofit] component at some point, but for right now with this funding model, we're just going to make it grant based [i.e. a nonprofit]. (Founder; SE_50)
\end{abstract}

Other founders communicate reasons that are tied more closely to personal beliefs and values The founder of the pie kitchen described previously explains, "I was just never interested in being a for-profit. [...] That's probably from my social work background. It's just not in my DNA - it's not in me to generate income" (Founder; SE_33). Another founder recounts a similar rationale: "The main reason to [set up as a nonprofit] - and I never feel like this is a good enough reason - but I think it's because I have more of a nonprofit spirit than what I think in mind as being a typical business, for-profit entrepreneur spirit" (Founder; SE_9). A third founder set up as a nonprofit because, "the do-gooder in me that was kind of like, "this [non-profit] is the way you do things"" (Founder; SE_41). Interestingly, these entrepreneurs, and many others, communicate choosing between organizational forms based on which form "felt right". Moreover, the stories they tell suggest that entrepreneurs naturally identify with either a business or nonprofit logic. Even though the decision to form as a for-profit or nonprofit often ends 
up having more legal than practical ramifications, entrepreneurs give this decision a prominent position in their personal narratives.

\section{Social-good Narratives}

A second narrative type communicated by social entrepreneurs can be termed social-good narratives. These narratives focus on elements of the social problem being addressed rather than on the social entrepreneur or the business side of the venture. They emphasize the beneficiaries of the enterprise, the social problem, the entrepreneur's proposed solution, and the social impact generated.

\section{Characters}

Whereas the focal characters in personal narratives are individual entrepreneurs or founders, in social-good narratives the venture's beneficiaries are center stage. Beneficiaries are the group(s) associated with the social problem addressed by the enterprise. They are contrasted with the customers of the business. For instance, in the TOMS Shoes model, "customers" are the consumers that purchase shoes and the "beneficiaries" are the children in the developing world that receive a free pair of shoes for each purchase. A social enterprise may have multiple beneficiary groups. For example, Urban Garden is a social enterprise that runs a youth development program that teaches at-risk urban children life skills by exposing them to sustainable agriculture. The enterprise sells a portion of the food grown by the youth to the public and donates the rest to local food kitchens serving the homeless. This venture has two beneficiary groups (i.e. at-risk youth, the homeless) and one customer group (i.e. the consumers purchasing their food). 
Beneficiaries are the main recipients of the "social good" created by the enterprise. In the Urban Garden example, life-skills, increased graduation rates, decreased incarceration rates, and food for the homeless, are all components of the social good produced by the enterprise. Social enterprises generally identify a focal, or core, beneficiary, which is the primary focus of their social mission. This is the group that is most associated with the social problem addressed by the enterprise and that receives the lion's share of the social good (or "social value"; Santos, 2010) produced by the venture. For instance, although Urban Garden benefits the homeless through its food donations, the venture was created to address social problems associated with at-risk youth. The latter group is its core beneficiary and the primary characters in its social-good narratives.

\section{Themes}

There are several common themes (and sub-themes) that constitute social-good narratives. Table 6 provides examples of each. 
TABLE 6: SOCIAL-GOOD NARRATIVES

\begin{tabular}{|c|c|}
\hline Theme (sub-theme) & Illustrative quote(s) \\
\hline \multicolumn{2}{|l|}{ Social Problem } \\
\hline General description & $\begin{array}{l}\text { "38 percent of all water projects [in the developing world] fail within } \\
\text { the first two years. [...] This is just such a ridiculously broken system } \\
\text { and we just keep telling donors to keep giving, giving, giving to end } \\
\text { this water crisis that's never going to end because we're funding a } \\
\text { broken system." (Founder/CEO; social enterprise_50) }\end{array}$ \\
\hline $\begin{array}{l}\text { Specific stories of } \\
\text { beneficiaries }\end{array}$ & $\begin{array}{l}\text { "Twe was born into a large family in the town of Mae Wa Due in } \\
\text { Burma's Karen state. After years of temporary escapes, Twe said her } \\
\text { family made the decision to flee Burma forever. [...] the move to the } \\
\text { U.S. has been filled with tough sacrifice. Her husband was unable to } \\
\text { find work }[\ldots] \text { and Twe craves to speak English well." (Founder; } \\
\text { SE_44) }\end{array}$ \\
\hline \multicolumn{2}{|l|}{ Proposed Solution } \\
\hline Why social enterprise? & $\begin{array}{l}\text { "I think social enterprises are one way that provides something for } \\
\text { folks that's beyond a Band-Aid." (Founder; SE_23) }\end{array}$ \\
\hline $\begin{array}{l}\text { Description of proposed } \\
\text { solution }\end{array}$ & $\begin{array}{l}\text { "[...] for every pair [of shoes] that we sell, we give a percentage to } \\
\text { provide healthcare and education on plantations where raw material is } \\
\text { cultivated." (Founder; SE_2) }\end{array}$ \\
\hline \multicolumn{2}{|l|}{ Social Impact } \\
\hline General description & $\begin{array}{l}\text { "So we started the Community Kitchen program and after three years } \\
\text { we had achieved a } 62 \text { percent graduation rate and an } 85 \text { percent } \\
\text { employment rate." (Founder; SE_23) }\end{array}$ \\
\hline Specific description & $\begin{array}{l}\text { "One of the stories that will always stick with me is that of Amleset } \\
\text { [...] Once she started working with our jewelry program, her life } \\
\text { changed. She was able to help provide for her family, and just this } \\
\text { past year they were able to move off of the mountain where HIV is so } \\
\text { prevalent [...] (Founder - SE_9) }\end{array}$ \\
\hline
\end{tabular}


Social Problem. One of the main components of social-good narratives is a compelling description of the social problem being addressing. In describing the problem, the entrepreneur attempts to communicate that it is a substantive issue and one that must be urgently addressed. There are, however, different ways an entrepreneur can convey the importance of the problem.

First, entrepreneurs can provide a generic description. For example, the founder of a social enterprise that provides an online tool to increase donations to entrepreneurs tackling water issues in the developing world provides a sweeping description of the social problem she addresses.

\begin{abstract}
38 percent of all water projects [in the developing world] fail within the first two years. And that's because a charity will draw the well and say, 'we passed it to the non-profit, or we passed it to government, or the local leader, or the village is going to pay into this funding scheme' and it just never happens. This is just such a ridiculously broken system and we just keep telling donors to keep giving, giving, giving to end this water crisis that's never going to end because we're funding a broken system. (Founder; social enterprise_50)
\end{abstract}

With this description the entrepreneur communicates a broad overview of the structural issues underlying a problem. This example represents a description that focuses primarily on the social problem. The entrepreneur does not, however, emphasize the groups affected by the problem (i.e. the social enterprise's beneficiaries). In contrast, the following entrepreneur, who employs refugees recently arriving in the United States, focuses less on the abstractions of the problem and more on the concrete, livedexperiences of the group that is affected.

[Refugees experience] a lot of isolation, people that wanted to work really hard, but they're not finding the opportunities to do that; and families who came with them - or a widow whose husband was killed in the warfare and who would come over here and then have to work for $\$ 7.25$ and then, she couldn't afford the family, and then falling in that poverty trap, having to rely on the 
government and wanting to live a life of dignity and choice and providing for her family. (Founder; SE_3)

The following social problem description takes a middle road, including some elements that are general (and focused on the social problem) and others that are specific (and focused on the social enterprise's beneficiaries).

\begin{abstract}
We understand that the people that we work with aren't popular and our people that we work with are defenseless against what's going on. Texas is the number one mass incarceration state in our country. There are 10 US states that make up 60 percent of all incarceration in our country. Those ten states have more incarceration than all of Russia - almost as much incarceration than the entire republic of China. Once you are in the system, forget it, and they start you at the youngest age. This social crisis is at the root of homelessness and poverty and foster care and I mean this is such a huge problem and no one is doing anything about it. (Founder; social enterprise_24)
\end{abstract}

Some social entrepreneurs are even more granular in their description of a social problem. Instead of communicating in general terms about the problem or about their beneficiaries, they try to convey the importance of their problem through stories of specific beneficiaries. For instance, the founder of a social enterprise that provides income and English-as-a-second-language (ESL) training to refugee artisans communicates about the social problem her venture addresses through the personal narrative of a beneficiary.

Twe was born into a large family in the town of Mae Wa Due in Burma's Karen state. Like many of our other artisans, she grew up helping her parents plant rice in the mountains surrounding her village. She attended school through the fifth grade before dropping out to help her family farm. After years of temporary escapes from their own homes, Twe said her family made the decision to flee Burma forever. [...] Many of Twe's extended family also made the move to the United States [...] the move to the U.S. has been filled with tough sacrifice. Her husband was unable to find work [...] and Twe craves to speak English well [...](Founder; SE_44)

The different ways of describing a social problem are not mutually exclusive.

Entrepreneurs often begin with a general description and then, for emphasis, 
provide concrete descriptions of the plight of their beneficiary groups and/or specific stories of individual beneficiaries.

Proposed Solution. In communicating about their ventures, social entrepreneurs must not only emphasize the social problem they are addressing, but also their particular solution for the problem. This "solution" corresponds to the social-good component of their business model. In describing their solution, entrepreneurs' often begin by explaining why social enterprise is the preferred method of addressing this problem.

As described above, an important component in social entrepreneurs' personal narratives is the story of why they chose to found a social venture rather than a traditional nonprofit organization or for-profit business. Moreover, entrepreneurs also explain that it is important to communicate why social enterprise, and not a more traditional organizational form, is the appropriate choice for addressing a social problem. For instance, the founder of a micro-finance social enterprise providing loans and education to women entrepreneurs in the developing world describes why she believes that social enterprise is the answer.

I feel like a lot of our [nonprofit] social services, while good - and I'm not saying we need to throw the baby out with the bathwater - but we have to figure out a way to do more than just Band-Aid and I think social enterprises are one way that provides something for folks that's beyond a Band-Aid. (Founder; SE_23)

Entrepreneurs also convey that their specific social enterprise is well-suited to address a social problem. For example, one founder endorses her social enterprise by emphasizing its sustainability over other models.

If we want to really end poverty and [provide] people jobs then you need to create sustainable systems. This [the social enterprise] is a sustainable system, and it's also going to be saving lives. (Founder; SE_50) 
Finally, one of the central elements of entrepreneurs' social-good narratives is their proposed solution to a social problem. Entrepreneurs focus on what their enterprise does to address the problem and also on specifically how their solution works. Solutions communicated by the following social entrepreneur provides clear examples.

So the social part of it is, for every pair [of shoes] that we sell, we give a percentage to provide healthcare and education on plantations where raw material is cultivated. It is very, very important for us to [provide] healthcare and education, because we consider them to be the two pillars to really make a change within a community, within a society. (Founder; SE_2)

Social Impact. As the second example illustrates, descriptions of the proposed solution to a social problem can focus heavily on the process underlying how a social enterprise enacts change. However, resource providers are often more concerned with the outcomes of this process - i.e. the social impact created by the enterprise. But social entrepreneurs vary in how they measure, and communicate about, their impact.

In constructing their social narratives, some entrepreneurs focus on quantitative measures of social impact, such as the amount of money raised (e.g. "I mean we're not huge now, but we've raised a little over $\$ 400,000.00$ [for beneficiaries] all very grassroots" [Founder; SE_50]); the number of beneficiaries impacted (e.g. "we've worked with over 700 immigrants and refugees in town and at 30 different sites, from the tiny places like Jose's to most of the hospitals, Good Foods, most of the downtown hotels" [Founder; SE_33]), and improvements in social impact metrics (e.g. "after three years we had achieved a 62 percent graduation rate, and an 85 percent employment rate" [Founder; SE_23]). 
Other social entrepreneurs prefer to express their impact using qualitative rather than quantitative descriptors. For example, many attempt to convey the social good they have created through specific stories of their beneficiaries and how their lives have been changed by the efforts of the social enterprise. For example, the founder of a jewelry and clothing company that sells goods designed and manufactured by African women with HIV/AIDS describes her company's impact by describing the social-good produced for a single beneficiary.

One of the stories that will always stick with me is that of Amleset, because it gives me so much hope. When she and her husband found out that they were HIV positive, they moved to Entoto Mountain in hopes of finding healing. But all they found was poverty. Amleset began begging [...] Once she started working with our jewelry program, her life changed. She was able to help provide for her family, and just this past year they were able to move off of the mountain where HIV is so prevalent, and assimilate back into life in the city. Amleset's story is one of true transformation that is so inspiring to me. (Founder; SE_9)

Social entrepreneurs argue that “telling a person's story is more compelling than talking about a 'refugee' (Founder; SE_30)." However, entrepreneurs often struggle with how to incorporate these stories into their larger social narratives. One entrepreneur, the founder of a clothing company that sources all of its materials from the developing world, describes the difficulty he has had with this issue.

We've played with a lot of different ways to tell the story of the company. We've talked about 'Fair Trade'; we've talked about 'organic'; we've talked about the consumers themselves. [Because] is the consumer the story? Is the consumer and the choices that they're making the story that we're trying to tell? But we found that the story that resonates the absolute most, right now at least, is when you're connecting back to the folks who have either farmed the cotton or made the garment. (Founder; SE_3)

The same entrepreneur describes why specific stories of beneficiaries can be more effective than narratives that are more general in their focus. 
Fair Trade ends up being a bit too nebulous, talking about 'ethical systems of economy'. Then the consumer feels like they're just one drop in the bucket. [There's] zero emotional attachment. And it's not, it's not human storytelling. And so, we have to tell human stories, to say, like, 'Nau gets to go to school, and his dad doesn't have to borrow money at usurious rates, and they get to have the life they wouldn't have had before because we support them; because they were able to grow the cotton that made these T-shirts.' (Founder; SE_3)

In the social enterprise practitioner literature and among informants there remains significant debate about which approach is most effective (i.e. quantitative measures, qualitative measures, or a combination of the two). In the next chapter, I present evidence which suggests that many of these decisions are not "either/or", but rather that it is important for entrepreneurs to tailor their social-good narratives, and persuasion techniques, to specific stakeholder groups.

\section{Business Narratives}

A third narrative-type, distinct from entrepreneurs' personal and social-good stories, is the business narrative. Unlike a traditional nonprofit organization or corporation, social entrepreneurs describe having to wear a "dual hat" (Informant_5) and communicate both social-good and business messages. Business narratives feature customers as their primary characters and are often targeted at investors. Unlike the social-good narrative, business narratives emphasize that the venture is, in fact, a business. In doing so, they describe the business and revenue models and provide the "business case" for why the venture will be successful and should receive investment.

\section{Characters}

The focal "characters" of business narratives are social enterprises' customers. Such narratives communicate who the customer groups are and why these groups are desirable targets. Moreover, they often contain a detailed description of the product, its 
features, and how customers will benefit from it. Finally, as described in detail in Chapter

8, business narratives can also include arguments for why groups other than the primary customer groups can benefit from the enterprise's products. Examples of each of these themes are provided in Table 7.

TABLE 7: BUSINESS NARRATIVES

\begin{tabular}{|c|c|}
\hline Theme (sub-theme) & Illustrative quote(s) \\
\hline Business Emphasis & $\begin{array}{l}\text { "We try to explain [to investors] we are a business. We are for profit, but } \\
\text { our profit goes into sustaining the business." (Founder; SE_8) }\end{array}$ \\
\hline $\begin{array}{l}\text { Description of } \\
\text { Business Model }\end{array}$ & $\begin{array}{l}\text { "We are the world's only social network for good, accelerating } \\
\text { philanthropy by connecting individuals, non-profits, and businesses } \\
\text { together to make millions of tiny donations." (Founder; SE_22) }\end{array}$ \\
\hline Revenue Model & $\begin{array}{l}\text { "Our revenue model is based on fundraising campaigns that are built on } \\
\text { top of our donor platform, cause-marketing campaigns [also] built on top } \\
\text { of our donor platform, and there's also one more component, consulting." } \\
\text { (Founder; SE_22). }\end{array}$ \\
\hline \multicolumn{2}{|l|}{$\begin{array}{c}\text { Business case for } \\
\text { the venture }\end{array}$} \\
\hline $\begin{array}{l}\text { Attractiveness of } \\
\text { market / market position }\end{array}$ & $\begin{array}{l}\text { "There's only really five or six competitors out there that I think are really } \\
\text { threats, that are doing good stuff that I feel, are playing in the same ball } \\
\text { park that we are." (Founder; SE_2) }\end{array}$ \\
\hline Financial strengths & $\begin{array}{l}\text { "We got proven year-by-year sales at the major licensed collegiate apparel } \\
\text { sales group in country. So we get a track record that's compelling enough } \\
\text { and we have relationships that will deepen." (Founder; SE_23) }\end{array}$ \\
\hline "Exit" mindset & $\begin{array}{l}\text { "You always operate your company as if you could sell it the next day, } \\
\text { and that is create the right margins, create the right product, give the right } \\
\text { incentive to people..." (Founder; SE_13) }\end{array}$ \\
\hline Clear use for funding & $\begin{array}{l}\text { "Series-A funding would allow us to bring in more of our production in } \\
\text { house which increases our margins and reduces our supply chain logistics } \\
{[\ldots] \text { (Founder; SE_2) }}\end{array}$ \\
\hline
\end{tabular}




\title{
Themes
}

Business emphasis. One of the dominant themes that social entrepreneurs try to convey is that the venture is indeed a business. Entrepreneurs are often quick to emphasize that they are not running a charity, a traditional non-profit, or a nongovernment organization (NGO).

\begin{abstract}
We try to explain we are a business. We are for profit, but our profit goes into sustaining the business. (founder; SE_8)

The reason that we are successful is we run it like a business. If there is somebody out there that we can partner with to provide services, to start a business, to do just about anything, we are very, very open to it. So that allows us to foster relationships internally and externally, and, again feeds the whole circle of the innovation and entrepreneurship that we are able to come up with. (Founder; SE_39)
\end{abstract}

However, social entrepreneurs differ in how much they emphasize the business side of their ventures. Some entrepreneurs communicate elaborate business narratives, containing most of the business-related themes discussed below. For these entrepreneurs, the business narrative is center-stage in their communication with resource providers. In contrast, other social entrepreneurs possess an underdeveloped business narrative, which is not a primary focus of their communication.

Business model. Business narratives often include a (high-level) description of the social enterprise's business model (i.e. the processes that enable a firm to create economic value; Stewart $\&$ Zhao, 2000) ${ }^{13}$. It can consist of a simple summary of what the business does and how it does it. For instance, one social entrepreneur succinctly summarizes their business in the following way:

\footnotetext{
${ }^{13}$ Like the definition of "narrative," the definition of "business model" is highly contentious (cf. Morris, Schindehutte, \& Allen, 2005); however, the definition chosen serves the purposes of this study.
} 
We are the world's only social network for good, accelerating philanthropy by connecting individuals, non-profits, and businesses together to make millions of tiny donations. (Founder; SE_ 22)

Many entrepreneurs choose to describe their social enterprise through comparisons with older, more established organizations. These comparisons can serve not only to help audiences make sense of what the venture does, but also represent attempts to gain legitimacy for the venture. For example, one founder describes his business using multiple comparisons.

I think we're pretty unique. [We're] like an Anthropologie for the aesthetic, meets TOMS Shoes for the social mission, meets Stella and Dot for the selling model. We kind of breed those three together. (Co-founder/CFO; SE_19)

Entrepreneurs can also emphasize the business - rather than social - problem they are addressing, why it is an important "pain point" with customers, and how the venture's resources and capabilities make it uniquely suited to address the problem.

Revenue Model. A related component of business narratives is a description of the social enterprise's revenue model (i.e. how the enterprise monetizes its activities). Similar to descriptions of their business model, some business narratives include detailed explanations of how they generate revenue from their activities, while others are less explicit. For instance, one social entrepreneur explains:

Our revenue model is based on fundraising campaigns that are built on top of our donor platform, cause-marketing campaigns [also] built on top of our donor platform, and there's also one more component, consulting. (Founder; SE_22).

An entrepreneur whose enterprise helps to improve the efficiency of medical equipment donations in the developing world, provides a more detailed overview of his revenue model.

There are a number of ways of doing that [generating revenue] but the things we're looking at are the transactional ways associated with the [medical] 
donations and also on the reports about how those donations got used. So we ask for a fee for managing [...] the process, but we don't require it. So the people that pay that fee benefit from the stories [of the beneficiaries]. Other [revenue generators] are advertising and marketing, branding. And there are other areas as well. Long term we are creating channels into these markets that people would be interested in the future. We are collecting a lot of data that no one has right now, a lot of data in countries that will eventually have markets for GE, Pfizer, and groups like that. (Founder; SE_5)

This example illustrates that, like traditional businesses, social enterprises' revenue models can be complex with multiple revenue streams and customer groups.

Business case for the enterprise. Like their traditional counterparts, social entrepreneurs often try to convince audiences that their business will be successful. One of the main audiences evaluating a social venture's likelihood of success is investors. In providing the "business case" for their enterprise, social entrepreneurs often discuss several topics.

First, they emphasize the favorable features of their market and their position in it. For instance, they may focus on the size, stability, or growth of their market, on their ability to penetrate (or gain traction) in the market, or on their position relative to competitors. For example, one entrepreneur explains:

Compared to other literacy providers, our outcomes and our outputs are just better. So we honestly can say, [we're] 'cheaper, faster, and better compared to other providers'. (Founder; SE_33)

Second, social entrepreneurs often focus on the favorable characteristics of their venture. For example, they may emphasize the quality of their founding team or board of directors and why these individuals are well-suited to address a particular business problem. Moreover, entrepreneurs often emphasize that their venture is particularly 
sustainable or scalable. Finally, many business narratives focus on the key details of the product being offering, such as its quality or price point.

Social entrepreneurs can also focus on the financial strengths of their business when communicating with investors. For example, some provide details about their business "fundamentals" such as profit margins, cash flow, sales, and revenue. Perhaps most interesting to investors, entrepreneurs also describe their projected return on investment (ROI). In general, entrepreneurs will emphasize their venture's "upside" and deemphasize the riskiness of the investment. Moreover, in making the case for a high ROI, some entrepreneurs emphasize sustainability of revenue streams, whereas others follow suit with traditional entrepreneurs and try to provide evidence of future exponential (i.e. "hockey stick") growth. One entrepreneur describes the attractiveness of his venture as follows.

The market is stable, our product is what it is, we have [market] presence, we have a management team that's able to pull this off, and there is a big enough market to make 10X return. (Founder; SE_12)

In addition to return on investment and the other factors described, entrepreneurs also often attempt to communicate to investors that they possess an "exit mindset" - i.e. the entrepreneurs have planned for and are anticipating a potential acquisition event. One way for entrepreneurs to convey this mindset is by providing examples of specific companies, or the type of company, that is likely to acquire their venture. As described in detail in the next chapter, social entrepreneurs vary widely in the extent that they convey such a mindset. Some communicate that one of their primary goals is future exit. For example, one founder explains: 
You always operate your company as if you could sell it the next day, and that is create the right margins, create the right product, give the right incentive to people... (Founder; SE_26)

In contrast, others communicate a strong antagonism towards exit, often because they do not want to leave the business that is allowing them to address a particular social problem.

Everyone is like, 'if you don't have an exit strategy you're just in the lifestyle business.' I was like, 'you don't get it, it's not about exiting ... I want to make sure that whatever we create has permanence.' (Founder/CEO; SE_20)

A final component of many business narratives focuses on how entrepreneurs would use funding if they were to receive it. Among entrepreneurs seeking investment, there is variance in the detail they provide about how funding would strengthen their ventures. For instance, some entrepreneurs are very specific about how they would use external investment.

Series-A funding would allow us to bring in more of our production in house which increases our margins and reduces our supply chain logistics and all the processes that go along with that and also with lead times because the order comes in, we ship it three or four months later. We'd love to have that be three weeks later. So that's going to be really big for us. Also to put together a marketing campaign. (Founder; SE_12)

Other social entrepreneurs are not as explicit in communicating precisely what they would do with external investment; they just convey that securing such investment would make their life "easier".

\section{Social Enterprise Narratives: A Typology}

To summarize, social entrepreneurs construct three types of narratives to communicate with stakeholders. Personal narratives are a compilation of experiences, attributes, significant events, and founding stories. These narratives are communicated to multiple stakeholder groups (investors, customers, employees, the media). As described, 
in theory they can serve a complex number of functions (e.g. signaling prestige, establishing legitimacy, demonstrating passion, integrating identities, fostering sensemaking).

Entrepreneurs also construct social-good narratives, which are focused on the venture's social mission rather than on entrepreneurs themselves or on the business side of the enterprise. Such narratives feature the beneficiaries of the venture. They attempt to communicate to audiences the depth of the social problem, how and why the entrepreneur is addressing it, and the social-good that is being created.

Finally, social entrepreneurs can also construct business narratives. These narratives focus on customers and investors rather than beneficiaries. They provide the business case for the venture and describe its business-related activities and strengths.

\section{Summary}

Prior social enterprise research has not explored the narratives social entrepreneurs use to communicate with their stakeholders. Practitioners, in contrast, have devoted significant attention to such narratives but they have not gone beyond the distinction between "social messages" and "economic messages" nor have they explored what elements constitute these narratives (e.g. Richardson, 2011; Smith, 2011). This study finds that, taken together, the three narrative-types form the building blocks of entrepreneurs' communication with their stakeholders.

There is significant variance, however, between social entrepreneurs in their use of the three narratives. For instance, some entrepreneurs communicate elaborate personal and social-good narratives, but devote very little effort to developing a business narrative. 
Similarly, there is also variance between entrepreneurs in the interdependence of these narratives. Moreover, some entrepreneurs emphasize different narratives with different audiences.

What drives these differences in narrative use? And how do these differences influence entrepreneurs' ability to persuade resource holders to provide them with resources? These questions and others involving how social entrepreneurs use the three narrative types in order to acquire resources are the focus of the next four chapters. 


\section{CHAPTER 6:}

\section{HOW DO SOCIAL ENTREPRENEURS USE NARRATIVES TO ACQUIRE RESOURCES?}

\section{NARRATIVE TAILORING}

In Chapter 5, I construct a typology that defines and describes three types of social enterprise narratives - personal, social-good, and business. Evidence from the communication of social entrepreneurs suggests that these narratives are important and theory would suggest that they can serve several purposes (e.g. legitimation, sensemaking). What remains unclear, however, is how social entrepreneurs use these narratives to communicate with resource providers.

Prior literature would suggest that stories are told by traditional entrepreneurs for at least three purposes: helping potential resource providers comprehend an entrepreneurial firm's identity, aiding prospective investors in understanding the nature and value of a firm's means of exploiting opportunities, and connecting to broader contextual narratives in such a way that the venture appears original and distinctive (Martens et al., 2007). While these purposes, and a number of others described in the previous chapter, are also served by social enterprise narratives, what is not understood are the specific narrative tactics social entrepreneurs engage in while seeking resources.

Moreover, evidence from the practitioner literature also suggests that social entrepreneurs do not fully understand the role of narratives in resource acquisition. Indeed, as Herz and Mertes (2008) explain, "social entrepreneurs understand the power of 
a well-told story...but they don't always know how to harness that power to drive awareness of their issue and adoption of their innovation." For example, the practitioner literature suggests that social entrepreneurs struggle with balancing their social-good and business narratives. When pitching their business to potential investors, this leads them to be unsure of whether they should emphasize a social or commercial message. As Smith (2011a) asks, “...in a world where social enterprise isn’t well understood and people think in pretty black and white terms about charity and business, how do you balance your social and business message? [...] Does it really matter whether people understand your social mission at all?" As this quotation illustrates, uncertainty exists within the social enterprise sector about how narratives can be used to communicate about social ventures. Indeed, there is very little consensus among practitioners about how social entrepreneurs should communicate about their ventures. There is even less consensus about whether the choice between a social or economic-focused narrative depends on the particular type of audience addressed (e.g. investors vs. the media).

This chapter, and the two that follow it, describe the findings of Study 2, which addressed the question, "how do social entrepreneurs use narratives to influence resource providers?" Specifically, I present findings from case studies of eight social ventures. I provide evidence that the narratives used by successful social entrepreneurs (i.e. those able to attract external financial investment) differ from those used by unsuccessful entrepreneurs (i.e. those not receiving funding). The data suggest that three narrativerelated factors influence entrepreneurs' ability to acquire resources. I find that successful entrepreneurs engage in two tactics - narrative tailoring (Chapter 6) and linking (Chapter 
7). Moreover, the narratives of successful social entrepreneurs possess a common characteristic: multiplexity (Chapter 8).

\section{Narrative Tailoring}

Evidence from Study 2 suggests that the social enterprises able to attract external investment deployed their narratives differently than unfunded enterprises. Successful enterprises engage in narrative tailoring, defined as adapting the emphasis of a narrative to match the interests of a particular audience. As described in detail below, when communicating with investors successful social entrepreneurs tailor their narrative communication to emphasize business narratives. In contrast, when communicating with other resource providers, such as the media, successful entrepreneurs tailor their narrative communication to emphasize personal and social-good narratives. I present evidence that in contrast to unfunded ventures, successful enterprises (1) believe tailoring is an important tactic and (2) engage in tailoring. I also provide evidence that investors are influenced by narrative tailoring. Table 8 provides support for these findings and summarizes the use of this tactic by each of the cases. 
TABLE 8:

NARRATIVE TAILORING

\begin{tabular}{|c|c|c|c|}
\hline COMPANY & $\begin{array}{c}\text { BUSINESS } \\
\text { NARRATIVES } \\
\text { AND INVESTORS }\end{array}$ & $\begin{array}{c}\text { BUSINESS } \\
\text { NARRATIVES } \\
\text { AND INVESTORS } \\
\\
\text { FUNDERS' } \\
\text { PERSPECTIVE }\end{array}$ & $\begin{array}{c}\text { SOCIAL-GOOD / } \\
\text { PERSONAL } \\
\text { NARRATIVES } \\
\text { AND OTHER } \\
\text { AUDIENCES }\end{array}$ \\
\hline $\begin{array}{c}\text { FUNDED } \\
\text { COMPANIES } \\
\text { Alpha }\end{array}$ & $\begin{array}{l}\text { Business emphasis. } \\
\text { "When I pitch, literally } \\
\text { the first thing out of } \\
\text { my mouth is, 'Don't let } \\
\text { the 'Giving' in our } \\
\text { name and the flower in } \\
\text { our logo fool you, we } \\
\text { are a business, and this } \\
\text { is why.' } \\
\text { (Founder/CEO) } \\
\text { "We think of ourselves } \\
\text { as a business first and a } \\
\text { social business second, } \\
\text { from an investor's } \\
\text { standpoint." } \\
\text { (Founder/CEO) } \\
\text { Excerpt from } \\
\text { business narrative: } \\
\text { Description of } \\
\text { business model. } \\
\text { "We [are] an online } \\
\text { coordination platform } \\
\text { [...] for corporations to } \\
\text { reach people with their } \\
\text { cause marketing } \\
\text { messages" } \\
\text { (Founder/CEO) }\end{array}$ & $\begin{array}{l}\text { Investor's value business } \\
\text { emphasis. } \\
\text { "[Alpha's] going after the } \\
\text { business case, which is } \\
\text { why I think they were } \\
\text { attractive to us." } \\
\text { (Investor3) } \\
\text { Investor's value } \\
\text { entrepreneur's } \\
\text { familiarity with business. } \\
\text { "[Invested in Alpha } \\
\text { because of CEO's] ability } \\
\text { to talk business." } \\
\text { (Investor2) } \\
\text { "[Alpha's CEO] can } \\
\text { understand the business } \\
\text { language." (Investor2) }\end{array}$ & $\begin{array}{l}\text { Social-good emphasis. } \\
\text { "Now, when we talk to } \\
\text { customers, that's a different } \\
\text { story. We flip it [focus on } \\
\text { social not business]." } \\
\text { (Founder/CEO) } \\
\text { "Alpha is a social venture, [...] } \\
\text { I've built a tool to help people } \\
\text { do good." (Founder/CEO) } \\
\text { Excerpt from social-good } \\
\text { narrative (to media): } \\
\text { Social-good solution. } \\
\text { "What we do is we help } \\
\text { improve the community } \\
\text { volunteering experience. } \\
\text { Excerpt from personal } \\
\text { narrative } \\
\text { (to media): } \\
\text { Exposure to social problem. } \\
\text { "So I was a school volunteer } \\
\text { and a working mom and I kept } \\
\text { noticing that my Blackberry } \\
\text { was filing up with reply all e- } \\
\text { mail request over whose turn it } \\
\text { was to help at table time or help } \\
\text { at recess." }\end{array}$ \\
\hline
\end{tabular}




\section{TABLE 8 (cont.)}

\begin{tabular}{|c|c|c|c|}
\hline Beta & $\begin{array}{l}\text { Business emphasis. } \\
\text { The primary topic [in } \\
\text { our pitches] is how } \\
\text { does this thing make } \\
\text { money? Then how do } \\
\text { you ensure your } \\
\text { runway? How do you } \\
\text { scale?" (Founder/CEO) } \\
\text { “[...] you have to } \\
\text { speak the language of } \\
\text { your audience whether } \\
\text { it's a potential client or } \\
\text { a potential investor, } \\
\text { and the language that } \\
\text { [investors] want to hear } \\
\text { is how they're going to } \\
\text { make money." } \\
\text { (Founder/CEO) } \\
\text { Return on investment. } \\
\text { "[With investors] our } \\
\text { objectives are the same } \\
\text { as a for-profit business. } \\
\text { [...] all of these guys } \\
\text { see us as an } \\
\text { opportunity to make a } \\
\text { big profit on their } \\
\text { investments, and } \\
\text { secondarily I think is } \\
\text { that it's a social } \\
\text { enterprise. } \\
\text { of micro-transactions. } \\
\text { You take a small piece } \\
\text { out of all of those and } \\
\text { that's our scalability." } \\
\text { (Founder/CEO) } \\
\text { buscerpt from } \\
\text { business narrative: } \\
\text { "In the end it's about } \\
\text { meving mony transaction that } \\
\text { business model is such } \\
\text { that we do lots and lots } \\
\text { ande model. }\end{array}$ & $\begin{array}{l}\text { Investors emphasize } \\
\text { business case. } \\
\text { "And then, I said, "okay, I } \\
\text { can understand the do- } \\
\text { gooding side of it, but, } \\
\text { you know, I make } \\
\text { investments for a return } \\
\text { on deploying capital, so, } \\
\text { let's talk about that." } \\
\text { (Investor1) } \\
\text { Return on investment. } \\
\text { "What it all boils down to } \\
\text { is because it is loyalty- } \\
\text { program centric and we're } \\
\text { in the middle of consumer } \\
\text { transactions, the value of } \\
\text { [Beta's] database is really } \\
\text { where the windfall's } \\
\text { going to come on the } \\
\text { backend. And the return } \\
\text { to investment when a } \\
\text { company comes in and } \\
\text { buys [Beta] because they } \\
\text { want that information is } \\
\text { going to be where the big } \\
\text { return comes." }\end{array}$ & $\begin{array}{l}\text { Excerpt from social-good } \\
\text { narrative (to media): } \\
\text { Social-good - } \\
\text { problem/solution. } \\
\text { "Economic times have been } \\
\text { tough in recent years and } \\
\text { people simply don't have the } \\
\text { expendable income to give. We } \\
\text { wanted to find a way to allow } \\
\text { everyday consumers to } \\
\text { participate in philanthropy." } \\
\text { (Founder/CEO) } \\
\text { "[...] our vision is to contribute } \\
\text { \$1 billion a year to traditional } \\
\text { philanthropy. That is front and } \\
\text { center of what we do." } \\
\text { (Founder/CEO) } \\
\text { Excerpt from personal } \\
\text { narrative (to media): } \\
\text { Prior work experiences. } \\
\text { "Beta was born as a result of } \\
\text { my previous career. I spent the } \\
\text { past decade working as a } \\
\text { consultant in the development } \\
\text { sector - advising governments, } \\
\text { civil society, the private sector, } \\
\text { and UN organizations in the } \\
\text { area of Local Economic } \\
\text { Development. Bringing } \\
\text { representatives of these types of } \\
\text { organizations into multi- } \\
\text { stakeholder decision making } \\
\text { processes (Founder/CEO) }\end{array}$ \\
\hline
\end{tabular}


TABLE 8 (cont.)

\begin{tabular}{|c|c|c|c|}
\hline Epsilon & $\begin{array}{l}\text { Business emphasis. } \\
\text { "By and large it's } \\
\text { [pitched as] a business } \\
\text {..[Our social message] } \\
\text { isn't a big part of it." } \\
\text { (Co-founder/CEO2) } \\
\text { Business case for } \\
\text { venture. } \\
\text { "[...] At the end of the } \\
\text { day they [investors] } \\
\text { want to see a } \\
\text { spreadsheet that says, } \\
\text { 'here's the return, } \\
\text { here's how this is } \\
\text { going to be self- } \\
\text { sustaining, and here's } \\
\text { going to be the returns } \\
\text { at year's } 3,5 \text {, and } 7 . " \\
\text { (Co-founder/CEO2) } \\
\text { Return on investment. } \\
\text { "[The angel] thought, } \\
\text { 'this is a cool idea and } \\
\text { it's going to do good } \\
\text {.. but realistically, am } \\
\text { I going to lose my shirt } \\
\text { on this'. And that's } \\
\text { what it was about. And } \\
\text { that's what the } \\
\text { conversation focused } \\
\text { on.” (Co- } \\
\text { founder/CEO1) } \\
\text { Excerpt from } \\
\text { business narrative: } \\
\text { Attractiveness of } \\
\text { market. } \\
\text { "A little bit about the } \\
\text { market: } \$ 8 \text { billion in } \\
\text { online giving last year. } \\
\text { That has actually been } \\
\text { growing at } 30 \text { percent } \\
\text { in the last couple of } \\
\text { years, and is increasing } \\
\text { at a faster pace. (Co- } \\
\text { founder/CEO1) }\end{array}$ & $\begin{array}{l}\text { Confirmation of business } \\
\text { emphasis. } \\
\text { [Epsilon] pitched it as a } \\
\text { dual business, saying, } \\
\text { "[...] Our [business] } \\
\text { solution is this and it's } \\
\text { going to create this kind } \\
\text { of revenue stream with a } \\
20 \text { percent growth, or } \\
\text { whatever it is, for } \\
\text { however long." } \\
\text { (Investor1) } \\
\text { Return on investment. } \\
\text { "You've got to find the } \\
\text { right investor, change the } \\
\text { pitch to them. [...] You } \\
\text { still have to spin the value } \\
\text { proposition and tailor the } \\
\text { pitch to the } \\
\text { individual.[...] They don't } \\
\text { survive the first filter cut } \\
\text { [at the investor's fund] } \\
\text { unless they have a return } \\
\text { on investment story." } \\
\text { (Investor1) }\end{array}$ & $\begin{array}{l}\text { Excerpt(s) from social-good } \\
\text { narrative (to media): } \\
\text { Social-good solution. } \\
\text { "We've created an entirely new } \\
\text { way for people to give. [...] By } \\
\text { incorporating giving into our } \\
\text { daily lives, everyone wins: } \\
\text { charities, nonprofits, } \\
\text { organizations and the people } \\
\text { they help." (Co-founder;CEO1) } \\
\text { Social impact - general. } \\
\text { "Imagine what would happen to } \\
\text { the budgets of nonprofits when } \\
\text { they start getting just 100 new } \\
\text { donors a month, every month } \\
\text { [...] (Co-founder; CEO1) } \\
\text { Excerpt from personal } \\
\text { narrative (to media): } \\
\text { Prior experiences - work / } \\
\text { non-work. } \\
\text { "It's way more than just a } \\
\text { business for our whole team. } \\
\text { [...] I started out working with } \\
\text { church camps and spent my } \\
\text { college summers working in } \\
\text { places like churches and } \\
\text { homeless shelters in East Los } \\
\text { Angeles. [...] Anyone that's } \\
\text { ever worked with a nonprofit or } \\
\text { charity has said things like "If } \\
\text { only we had this cash, we could } \\
\text {..." and while overseas, we } \\
\text { definitely had our share of those } \\
\text { moments. After we returned } \\
\text { from Europe, I spent about six } \\
\text { years with IBM, working on } \\
\text { analyzing threats to the Internet } \\
\text { at large." (Co-founder /CEO1) }\end{array}$ \\
\hline
\end{tabular}


TABLE 8 (cont.)

\begin{tabular}{|c|c|c|c|}
\hline Gamma & $\begin{array}{l}\text { Business emphasis. } \\
\text { "So as I'm pitching } \\
\text { investors, I start with } \\
\text { the business solution." } \\
\text { (Founder/CEO) } \\
\text { "[Do you communicate } \\
\text { that you are a 'social } \\
\text { enterprise' to } \\
\text { investors?] The answer } \\
\text { is no. Because I pitch } \\
\text { the business first, and } \\
\text { the social component is } \\
\text { kind of secondary." } \\
\text { (Founder/CEO) } \\
\text { Excerpt from } \\
\text { business narrative: } \\
\text { Business case for } \\
\text { venture; attractiveness } \\
\text { of market. } \\
\text { "Gamma is a concept } \\
\text { that solves the business } \\
\text { problem for } \\
\text { restaurants. It's } \\
\text { focused in restaurants } \\
\text { today. And the reason } \\
\text { it's focused in } \\
\text { restaurants is it's a } \\
\text { massive market We } \\
\text { spent over } 623 \text { billion } \\
\text { dollars last year in } \\
\text { restaurants just in the } \\
\text { US. Which creates a } \\
\text { market of close to } 90 \\
\text { billion dollars for } \\
\text { Gamma." } \\
\text { (Founder/CEO) }\end{array}$ & $\begin{array}{l}\text { Investors value business } \\
\text { case / Disregard social- } \\
\text { good narrative. } \\
\text { "So, in my opinion, [...] } \\
\text { that deal was done based } \\
\text { on 'does Gamma have } \\
\text { something that will take } \\
\text { off, and all the restaurants } \\
\text { in America will see its } \\
\text { merit, and there will be } \\
\text { wealth built.' I don't } \\
\text { think anybody in our } \\
\text { group invested in it so that } \\
\text { money will be given to a } \\
\text { food bank." (Investor1) }\end{array}$ & $\begin{array}{l}\text { Excerpt from social-good } \\
\text { narrative (to media): } \\
\text { Social-good-solution. } \\
\text { "I think we are doing something } \\
\text { significant, I personally believe } \\
\text { we can solve hunger in the U.S. } \\
\text { It's very solvable." } \\
\text { (Founder/CEO) } \\
\text { Excerpt from personal } \\
\text { narrative (to media): } \\
\text { Prior work/non-work } \\
\text { experiences. } \\
\text { "The idea came from the } \\
\text { college exploits of my partner } \\
\text { the company's Founder/CEO. } \\
\text { He was a student at the } \\
\text { University of Toronto, working } \\
\text { his way through school playing } \\
\text { jazz piano." (CSO) }\end{array}$ \\
\hline
\end{tabular}




\section{TABLE 8 (cont.)}

\begin{tabular}{|c|c|c|c|}
\hline Lambda & $\begin{array}{l}\text { Business emphasis. } \\
\text { "[Investors] want to } \\
\text { give you a hug if you } \\
\text { use the label 'social } \\
\text { entrepreneur', but they } \\
\text { may not want to invest } \\
\text { in you. } \\
\text { You really have to } \\
\text { make the case that, } \\
\text { yeah we're doing good, } \\
\text { but we have the } \\
\text { potential to be very } \\
\text { profitable." } \\
\text { (Founder/CEO) } \\
\text { Excerpts from } \\
\text { business narrative: } \\
\text { Attractiveness of } \\
\text { market / market } \\
\text { position. } \\
\text { "So how big [a market] } \\
\text { are we talking? Social } \\
\text { service agencies, } \\
\text { there's } 1.4 \text { million of } \\
\text { these programs in the } \\
\text { country. [...] Our } \\
\text { traction so far: we } \\
\text { launched the } \\
\text { application with two } \\
\text { paying customers. We } \\
\text { have } 21 \text { in our } \\
\text { pipeline... We've been } \\
\text { able to get } 18,000 \text { users } \\
\text { and we've been able to } \\
\text { get } 200 \text { different } \\
\text { agencies that have } \\
\text { workers that are using } \\
\text { our platform without } \\
\text { any outside financing. } \\
\text { " Founder/CEO) } \\
\text { (Fong }\end{array}$ & $\begin{array}{l}\text { Confirmation of business } \\
\text { emphasis. } \\
\text { "It was more the latter } \\
\text { [pitch focused on Lambda } \\
\text { as a solid business] than } \\
\text { the former [pitch focused } \\
\text { on the social mission]; it } \\
\text { was business first." } \\
\text { (Resource Provider1) } \\
\text { "The social enterprises } \\
\text { that struggle are the ones } \\
\text { that pitch 'here's how } \\
\text { we're changing the world } \\
\text {.. we'll figure out how to } \\
\text { monetize later." } \\
\text { (Resource provider2) } \\
\text { Disregard social-good } \\
\text { narrative. } \\
\text { "The social good stuff is } \\
\text { just marketing. Now I'm } \\
\text { not at all saying that's } \\
\text { what the entrepreneur } \\
\text { believes or that that's } \\
\text { what customers believe, } \\
\text { but for me that's all it is. } \\
\text { (Resource Provider2) }\end{array}$ & $\begin{array}{l}\text { Excerpts from social } \\
\text { narrative (to media): } \\
\text { Social-good - } \\
\text { problem/solution. } \\
\text { "[With Lambda] anybody in } \\
\text { need can find a food, health, } \\
\text { housing or education program } \\
\text { in seconds. No reading poorly } \\
\text { written government websites. } \\
\text { Someone may be looking for } \\
\text { short-term food help - but they } \\
\text { may not know that there's a rent } \\
\text { subsidy program they qualify } \\
\text { for just down the street. We } \\
\text { want to make sure that people } \\
\text { are making informed decisions } \\
\text { during a critical time. } \\
\text { (Founder/CEO) } \\
\text { Excerpts from personal } \\
\text { narrative (to media): } \\
\text { Exposure to social problem; } \\
\text { trigger events } \\
\text { "Lambda was an idea that took } \\
\text { ten years, but it started with my } \\
\text { mom. I became my mother's } \\
\text { guardian in } 2002 . \text { In } 1992 \text { she } \\
\text { had brain damage as a result of } \\
\text { a bad case of Encephalitis. [...] } \\
\text { Through that experience I came } \\
\text { to learn that there are services } \\
\text { available, but they were very } \\
\text { difficult to track down." } \\
\text { (Founder; Lambda) }\end{array}$ \\
\hline
\end{tabular}


TABLE 8 (cont.)

\begin{tabular}{|c|c|c|c|}
\hline \multicolumn{4}{|l|}{$\begin{array}{l}\text { UNFUNDED } \\
\text { COMPANIFS }\end{array}$} \\
\hline Rho & $\begin{array}{l}\text { Possess a clear social- } \\
\text { good narrative but only } \\
\text { a semi-developed } \\
\text { business narrative. } \\
\text { There is no evidence } \\
\text { that the business } \\
\text { narrative is emphasized } \\
\text { in communication with } \\
\text { investors. }\end{array}$ & $\begin{array}{l}\text { Not applicable; has not } \\
\text { received funding. }\end{array}$ & $\begin{array}{l}\text { Excerpt(s) of social narrative } \\
\text { (with media): } \\
\text { Social problem solution. } \\
\text { "We want to scale social good } \\
\text { through technology by } \\
\text { transforming the way small and } \\
\text { medium sized non-profits use } \\
\text { technology. } \\
\text { Excerpt(s) of personal } \\
\text { narrative (with media): } \\
\text { Exposure to social problem. } \\
\text { "A few years ago, John and I } \\
\text { went on a pro bono IT } \\
\text { consulting project to Uganda } \\
\text { [...] We saw the power of } \\
\text { grassroots and peer-to-peer } \\
\text { fundraising and the impact that } \\
\text { it can have. From there we were } \\
\text { inspired to scale social good } \\
\text { through technology." (Co- } \\
\text { founder/CEO) }\end{array}$ \\
\hline Sigma & $\begin{array}{l}\text { Has not developed a } \\
\text { business narrative. } \\
\text { Evidence of lack of } \\
\text { tailoring: } \\
\text { Social-good emphasis. } \\
\text { "[Sigma] was created } \\
\text { as a new revenue } \\
\text { source for nonprofits. } \\
\text { We're not a nonprofit. } \\
\text { [But] Sigma was not } \\
\text { created to make money } \\
\text { for the company } \\
\text { itself." (Founder/CEO) } \\
\text { "The main reason for } \\
\text { creating this was not to } \\
\text { create cash flow." } \\
\text { (Founder/CEO) }\end{array}$ & $\begin{array}{l}\text { Not applicable; has not } \\
\text { received funding. }\end{array}$ & $\begin{array}{l}\text { Excerpt(s) of social narrative } \\
\text { (used with all resource } \\
\text { providers): } \\
\text { Social impact - general. } \\
\text { "We have an opportunity to } \\
\text { bring back [to nonprofits] } \\
\text { initially cents, then dollars, and } \\
\text { then hundreds of dollars and } \\
\text { hopefully hundreds of } \\
\text { thousands of dollars, and it's all } \\
\text { done with simple commerce." } \\
\text { (Founder/CEO) } \\
\text { Under-developed personal } \\
\text { narrative. } \\
\text { Sigma's founder incorporates } \\
\text { very few elements of his } \\
\text { personal narrative into the } \\
\text { narratives of the venture. }\end{array}$ \\
\hline
\end{tabular}


TABLE 8 (cont.)

\begin{tabular}{|c|c|c|c|}
\hline Omega & $\begin{array}{l}\text { Has a well-developed } \\
\text { social-good narrative } \\
\text { but significantly less- } \\
\text { developed business } \\
\text { narrative. } \\
\text { There is no evidence } \\
\text { that the business } \\
\text { narrative is emphasized } \\
\text { in communication with } \\
\text { investors. }\end{array}$ & $\begin{array}{l}\text { Not applicable; has not } \\
\text { received funding. }\end{array}$ & $\begin{array}{l}\text { Evidence of lack of tailoring } \\
\text { I don't use that language [social } \\
\text { enterprise] because I view us as } \\
\text { infrastructure." (Co- } \\
\text { founder/CEO2) } \\
\text { "We're the same as when you } \\
\text { send out a mailing, you need } \\
\text { somebody to do all the } \\
\text { envelopes, do all the stamps, do } \\
\text { the inserts, collect all the data. } \\
\text { (Co-founder/CEO2) } \\
\text { Semi-developed social } \\
\text { narrative: } \\
\text { "What if every time you } \\
\text { tweeted it would be worth } \\
\text { money to a nonprofit? A penny, } \\
\text { a nickel, or a dime?" (Co- } \\
\text { founder/CEO1) } \\
\text { Under-developed personal } \\
\text { narrative } \\
\text { Founders made conscious } \\
\text { choice not to communicate } \\
\text { personal narratives. }\end{array}$ \\
\hline
\end{tabular}

\section{What is Social Enterprise Narrative Tailoring?}

The data indicate that successful social entrepreneurs develop all three types of narratives - personal, social-good, and business. They then tailor their narrative communication to fit different audiences. Tailoring is based on a simple idea: audiences differ in the types of narratives by which they are influenced. Or, put simply, different audiences want to hear different things. Although this may seem like an obvious and intuitive insight, many social entrepreneurs do not possess it. Indeed, there is very little evidence that unsuccessful social enterprises make use of this insight. 
Successful social entrepreneurs, in contrast, demonstrate clear evidence of narrative tailoring. Many of them are also very explicit about the fact that they tailor their narrative communication for different audiences. An example that illustrates this is Alpha. Alpha is a social enterprise with two major funding successes: receiving seed and Series-A rounds of investment. The seed round was from an established, local angel group; whereas the Series-A round was led by a prominent, national venture capital firm. The founder and CEO explains how she adapts her narrative communication to appeal to multiple audiences, including investors.

For small nonprofits, we're volunteer management software. For moms, we're an online sign-up sheet. I mean, if you want me to be a social enterprise, that's fine, or if you want me to be a sick viral mom tool, then I can be that too. I could show you five different [slide] decks, depending on who I'm talking to and what day.

As the quotation illustrates, this CEO recognizes that she has at least five audiences: nonprofits (a secondary customer group), "moms" (the primary beneficiary group), stakeholders interested in social enterprise (e.g. perspective employees), corporations (the primary customer group), and investors. For each of these groups she emphasizes a different message that corresponds with a unique way to frame her business. Her statement also suggests that she is aware that she emphasizes different narratives and that she purposively does so depending on with whom she is communicating. Thus, in this case, tailoring is the result of deliberate rather automatic cognition (Bargh \& Chartrand, 1999). 
Alpha's CEO elaborates on how and why she feels it is necessary to tailor her narratives. In doing so, she uses the "business emphasis" theme from the business narrative.

So when I pitch, literally the first thing out of my mouth is, "Don't let the 'Giving' in our name and the flower in our logo fool you, we are a business, and this is why." Because the minute investors hear "giving," they shut off. Now, when we talk to volunteers it's a different story. We flip it [focus on the social message]. And then also, cause marketing is so important for brands right now. So for them we become a platform to reach people with their cause marketing messages.

In this passage the CEO describes her communication to three groups: investors, beneficiaries, and customers. The CEO suggests that it is necessary to tailor her messages because investors do not want to hear about the social-good component of the business. In contrast, she contends that beneficiaries (i.e. individual volunteers) are more interested in the venture's social mission. However, corporations (i.e. "brands"), which are the venture's primary customer group, are interested in how the service provided can be used for cause marketing. Thus, the CEO suggests that communicating with the three audiences requires emphasizing different messages.

Alpha's CEO's description of the narratives used with different audiences also suggests that tailoring is not necessarily deceitful or duplicitous - i.e. it is not equivalent to speaking out of "both sides of one's mouth." Alpha is in fact all of the things described (volunteer management software, online sign-up sheet, social enterprise). Tailored narratives emphasize different facets of the social enterprise. They are not conflicting narratives. For instance, the CEO does not have one narrative describing how the company is volunteer management software and another narrative describing why it is not volunteer management software. Rather, each narrative emphasizes a unique facet of 
the organization, theme, or character group and brings it to the forefront of the communication.

\title{
Tailoring: Business Narratives and Investors (Entrepreneurs' View)
}

The above quotations, and column 1 in Table 7, provide evidence for a key practice of the successful social enterprises: when communicating with investors, the successful social entrepreneurs tailored their narratives to disproportionately emphasize the business "side" of their ventures. Indeed, with investor audiences, these entrepreneurs focused almost exclusively on their business narratives and under-emphasized personal and social narratives. Alpha's CEO describes engaging in this practice.

\begin{abstract}
"Some of our angels like that we're a double bottom line company It maybe made it easier for them to write a little bigger check or be willing to take the step. But the majority of our angels are there for our business case, not for our social mission. [...] does this one bet out of the ten bets they make, make them feel a little better regardless of what happens to us? [...] We think of ourselves as a business first and a social business second, from an investor's standpoint."
\end{abstract}

Although the CEO also states, "we absolutely consider ourselves a social venture," she recognizes that, with investors, her communication must possess a different prioritization - business first, social-good mission second.

Gamma provides a stark example of emphasizing the business narrative with investor audiences. The company was founded by a serial telecommunications and internet entrepreneur; however it is the founder's first social enterprise. Gamma was able to secure a significant round of angel investment from a regional angel group early in life of the venture. The CEO explains his narrative strategy when communicating with these investors.

[Do you communicate that you are a 'social enterprise' to your investors?] The answer is no. Because I pitch the business first, and the social component is kind of secondary. [I pitch] a business problem, a solid revenue model to generate 
funds and profitability. It's a solid business. It's not just a social venture. I think that the social value that we bring is over and above solving a business problem. So I call it the cherry on top.

The CEO touches on three themes from the business narrative: the business problem (or "pain point"), the revenue model, and the business case for the venture. He also makes it clear where the social-narrative fits in communication with investors. Although it is not absent from such communication it is relegated to being a subordinate element ("the cherry on top").

It is not sufficient, however, for social entrepreneurs to simply engage in business "talk"; rather, successful entrepreneurs constructed fully-developed business narratives that communicated several specific themes. An example providing a more detailed illustration of the use of several business themes is found in the communication of Beta's CEO. Like Alpha, Beta has also been successful in acquiring seed and Series-A rounds of funding. In both rounds, the same angel served as the lead investor and helped to organize the other investors. The CEO describes communicating about his venture to this investor.

The primary topic [in our pitches] is how does this thing make money? Then how do you ensure your runway? How do you scale? [With investors] our objectives are the same as a for-profit business. [...] all of these guys see us as an opportunity to make a big profit on their investments, and secondarily I think is that it's a social enterprise. So bottom line is people don't want to invest unless they know they're going to get a good ROI. So we built our business model with that in mind knowing that if it [the pitch] is all about the soft package or the community benefits, you're kind of shooting yourself in the foot because you've got to create a value proposition that can attract investors.

Beyond these themes, the $\mathrm{CEO}$ emphasizes the importance of communicating one point in particular: that the company has an exit strategy. 


\begin{abstract}
One point that's worth mentioning is we put a lot of attention on exit strategy. So we've established partnerships with a number of companies that are most likely to acquire us at some point $[\ldots]$ which, again, makes us slightly more attractive for an investor. [...] yes, we're trying to do something good but we're also trying to ensure that our investors will have the liquidity event at some point. Because operating in perpetuity for the benefit of the world or the community is not always that appealing to investors.
\end{abstract}

Executives in all of the social enterprises successful in getting investment commented that they thought it was important to at least be able to communicate with investors about an exit strategy and the possibility of a liquidity event. In contrast, entrepreneurs in the unfunded social ventures often displayed an aversion to the idea of exit and thus did not develop this theme in their business narratives.

As discussed in Chapter 5, the idea of exiting the business is a difficult subject for many social entrepreneurs because the social problem they are addressing is often closely tied to their identity and life-narrative. Lambda, which was initially unsuccessful in acquiring investment but which found success during the course of the study, had an especially difficult time incorporating an exit strategy into their business narrative. In an early conversation, Lambda's founder and CEO expressed a strong desire to find investors willing to take a "slow money" approach (i.e. willing to invest for a long period of time without concern for a quick return or exit). He explained, "ideally, I would like to work with people that want to help build and aren't just thinking about exits."

After several months of not being able to find such investors (even among socalled "impact", or social-good, investors), the CEO was still resistant to the idea of having to develop an exit plan. He stated, "I mean, how can I plan to sell [Lambda] when it pretty much represents the culmination of my adult life experience?" But, shortly before Lambda finally received an initial round of angel investment, a member of the 
founding team communicated that their outlook towards the topic of "exit" had shifted. She explained that after numerous meetings with investors where they were pressed on their exit strategy, they had decided to have an intern research the exits of other companies in their space. Based on this information, they had at least begun to develop an exit scenario that they could discuss with investors. She explained, "I guess we've sort of had to shift our thinking to, "well, if we felt like the company was on the right track, then yeah, maybe $[\ldots]$ we would do an exit. ${ }^{" 14}$ Not only does this illustrate that it is important to be able to at least communicate with investors about a potential exit, but it also highlights that social entrepreneurs' narratives evolve over time (the latter point is examined in more detail in Appendix A).

Thus far, the data presented suggest that successful social entrepreneurs believe it is important to tailor their communication to emphasize a business narrative with investors. This is, however, only evidence that entrepreneurs claim that this practice is important. It is not evidence that entrepreneurs actually engage in this type of communication strategy. Thus it is important to present examples of tailored narratives and tailoring "in action".

Tailoring: Business narratives and investors (an example)

Evidence from a successful pitch by Epsilon provides a clear example of tailoring in situ. The pitch was to approximately 20 angel investors all affiliated with the same

\footnotetext{
${ }^{14}$ For many social entrepreneurs, this "shift" in thinking comes after the realization that it is unlikely that their business will survive without external investment, which makes their reluctance towards a future exit a moot point. An entrepreneur interviewed in Study 1 summarized this sentiment, "[I realized] the first rule of 'sustainability' is to stay in business."
} 
angel network. Shortly after the pitch, the group decided to invest $\$ 250 \mathrm{~K}$ in Epsilon, which helped the venture to weather a difficult period of growth.

In the pitch Epsilon's founder and CEO emphasized several elements of the social enterprise's business narrative. First, the CEO described the venture's business model. He began with a succinct description of the business, "In a nutshell what is Epsilon? So the Epsilon platform is a cloud-based pledge engine integrated with Facebook, Twitter, and other social networks enabling fun, easy, group-based donations." He then provided more detail on what the venture does.

We can tie donations to anything. Anything somebody's passionate about, we can do it. If you want to walk a mile, we can tie a donation to it, automate that, and handle that for thousands and thousands and thousands of users on a large Facebook scale. We can do it. We've built the technology to do it.

Next the CEO described the revenue model. In doing so, he emphasized that the venture has three revenue streams (i.e. transaction fees from individual/nonprofit users, licensing fees, and consulting fees).

How do we make money on this? We keep five percent of each donation. Another alternate revenue stream is $[\ldots]$ licensing fees and consulting services for customizing Epsilon.

Epsilon's CEO also focused on the primary (nonprofits) and secondary (corporations) customer groups and why their technology is appealing to each. For instance, he explained:

Non-profits love this. It's new, it's exciting, it's different, and it ties giving to passion. The white label is another option we're doing where we take our existing website and we brand it for a specific company, let's say a Winn-Dixie or a Best Buy. And their employees would then have an internal corporate philanthropic platform, a membership giving platform that they could use and tie metrics to. And large companies are huge about this. 
Next, the CEO communicated another common business narrative theme, the "business case" for the venture. This involved touching on several topics including the attractiveness of the market, the superiority of their technology, their competitive advantage, the quality of their founding team, and a description of their competitors (and their shortcomings). An example of each is provided.

"A little bit about the market: $\$ 8$ billion in online giving last year. That $\$ 8$ billion has actually been growing at 30 percent in the last couple of years, and is increasing at a faster pace. Now that we have mobile technology, everybody's on the internet. So this [market] is only going to get larger and larger."

The other thing that's $[\ldots]$ making this market explode right now is that that they believe within three years more than ten percent of all marketing budgets will be cause-based. That is a large space right there.

So I wanted to mention that it looks like we're doing a lot, but it's because we have just an amazing core technology that is very sound, very robust, and it's very expandable because of the nature and the way we've built it.

Competitive advantage [...] we've got patent-pending technology on rule-based giving. That patent's actually - it's a great patent, and it's currently in process with the PTO.

And we've got a great team. Believe it or not, I'm not the nerdiest one on the team, and that's a really good thing. And we've got John who's a creative genius. And we've got a great company culture, which is actually - it's easy to undersell. But the guys love what we're doing. We're all passionate because we're building an excellent company.

[Competitor 1] hasn't really done much in terms of newness, innovation to keep customers there. [...] if you can build something that takes advantage of the way people interact on social networks and tie that to their lifestyle, hobbies, and passions, it's actually really powerful. None of our competitors are doing that. Our competitors have taken this older paradigm of the monkey with the bell or the - you know, passing the hat around, and that's what they've done online.

In choosing to emphasize these themes over others, the CEO paints the picture of the social venture as a strong, well-positioned, technology company.

Although Epsilon's CEO focuses heavily on the company's business narrative, as described below, successful social entrepreneurs spoke about their ventures very differently when communicating with other resource providers (e.g. the media). 
Moreover, while the business narrative is overwhelmingly dominant in the CEO's communication with investors, it is not the only narrative used. Also included are small pieces of the CEO's personal narrative and the enterprise's social-good narrative. This practice of combining (or "linking") narrative-types is the focus of Chapter 7.

\section{Tailoring: Business Narratives and Investors (Investors' Assessments)}

In the previous two sections I provided evidence to demonstrate that the entrepreneurs of successful social enterprises (1) believe it is important to emphasize business narratives with investors and in fact (2) use tailored narratives in their communication with funders. It is also important, however, to demonstrate that investors in these ventures actually value and prefer such narratives.

The investors involved with the ventures in this study were nearly unanimous in their insistence that it is the "business case" of a social venture that makes it attractive. An example of this is Alpha's investors. One of the company's investors, a serial technology angel, explains his "philosophy", which influences what he wants to hear from entrepreneurs when evaluating their social enterprises. He uses the analogy of having different "buckets" of investment money. This is a common analogy, and way of grouping types of firms, described by several investors.

My philosophy on it is, when an investor has the kind of money that they can make investments, they plan their finances and they put things into buckets. And there's one bucket full of money, and I'm not touching it because that's my 'nest egg'. Here's another bucket full of money I make investments out of. And there's another bucket full of money that's my philanthropy money. [But] there's no bucket for social good [i.e. social enterprise] stuff. There's a bucket for investments and there's a bucket for philanthropy. And so when you come talk to me, the first thing I'm trying to figure out is which bucket you're in. And if you're in the investment bucket, then you have to compare favorably to other 
investments. I'm not going to sacrifice the investment bucket, because I'm making [that] bucket so I can make more for the philanthropy bucket.

The investor explains that what was attractive about Alpha is that they were able to communicate that the venture was a strong business (i.e. Alpha "fit" in the investment bucket) and that the social good component of the business actually strengthened the business model.

Alpha is a real business [...]. At first, I thought it was just a social good thing. And I had to sit for a while and get comfortable with it. And then I was like, okay, this is a real business, and actually, it's going to grow faster and get bigger because it has these other [social good] qualities. In fact, I would argue that the best ones [social enterprises] are like Alpha, [they] are going to be ones where the social good makes it a better damn investment. Like that's the sweet spot, right? Where it's not a sacrifice that there's a social good. It's actually going to work way better because of the social good. [...] or at least that's how you want to position it or pitch it.

Alpha's other investors, who are members of a different angel group, express a similar

assessment of why the venture's pitch was attractive. One investor explains:

I'm pretty sure that there was very little thought about "hey, this is socially beneficial or social entrepreneurial" in why we are investing in them. We are investing in them because we think there's a market there. We think she [the $\mathrm{CEO}$ ] actually has a tool that will benefit that market and will make it interesting for us and we think that we're going to get a return on our investment on that.

This investor also expresses the common idea that during a pitch it is more important to try to assess the quality of the "jockey" (i.e. the CEO or founding team) than the "horse" (the venture itself or the idea). He explains that the angels in his group decided to invest in Alpha because they were "investing in [the CEO]." More specifically, they lauded the CEO for her "ability to talk business."

The investor contrasts Alpha's CEO with an unsuccessful social entrepreneur that recently pitched to their group: an "entrepreneur came through part of our process and when asked what their expectation of profitability was, their response was 'We don't 
know if we'll make money or not.' - I don't have to tell you how long the rest of the process went for them!" In comparison, the CEO of Alpha is described as communicating that she "can make a social difference while running a viable and profitable business." The investor summarizes their support of Alpha's CEO by reiterating that "[the CEO] can understand the business language. If you're going to have a conversation with investors and you can't talk the business language ... then the conversation is probably going to not last long."

Interestingly, Alpha's CEO placed so much emphasis on the business narrative with her most recent group of investors that the lead investor did not even consider Alpha a social enterprise. In fact, he explained that he did not have any social enterprises in his portfolio. When asked about Alpha he stated, “Alpha [...] certainly wouldn't fall under the definition of 'social entrepreneurship' for me" because "I think they're purely going after the business case, which is why I think they were attractive to us." This investor's assessment of the company is surprising and suggests that Alpha's business narrative is particularly persuasive. As described above, the name of the company is very suggestive of it being a social enterprise. In addition, the company's slogan, which is directly beneath its name on all company communications (e.g. website, press releases), has a clear "social good" theme. Interestingly, Alpha's CEO is aware of the effect that the business narrative has on some investors.

We absolutely consider ourselves a social venture: our goal is to do good and make money. We're a double bottom line company, but we're different than a lot of social ventures in that half or our investors don't consider us a social venture. 
The feedback from Alpha's investors, as well as the company's success - they have received the most external investment of any of the 60 social enterprises interviewed - is evidence that emphasizing a business narrative to investors is an important component in portraying a venture as an attractive investment.

The experiences of Lambda serve as evidence that angels and VCs are not the only providers of financial resources that espouse valuing business narratives. Incubators are another key resource provider for both traditional and social enterprises (e.g. Chen, 2009). In addition to providing entrepreneurs with office space and other forms of infrastructure, they are also a valuable source of networks and often help entrepreneurs to craft their pitches and meet potential investors. Before receiving its round of angel investment, Lambda was accepted into a technology-focused incubator. A director of the incubator described helping Lambda's CEO craft his pitch: "You have to communicate that you are building a viable entity - solving [social] problems is good, but building viable, sustainable entities is the mechanism with which you do that." Another director, who is also a private investor in technology ventures, explains how he views the social good component of Lambda's business:

The social good stuff is just marketing. Now I'm not at all saying that's what the entrepreneur believes or that that's what customers believe, but for me that's all it is. And I think that's the function that most investors see it having

The director also points out why, in his opinion, so many social enterprises struggle to secure investment. He states, "the social enterprises that struggle are the ones that pitch 'here's how we're changing the world ... we'll figure out how to monetize later.' You can't do that, this isn't Google. That ship has sailed." 
The director's last assertion - that unsuccessful social enterprises focus too heavily on their social mission when communicating to investors - is a recurring theme. Specifically, instead of using a business narrative with investor audiences, unsuccessful social enterprises overly emphasis their social and personal narratives with funders. The CEO of Beta, a funding success, describes this practice in fellow social entrepreneurs.

A lot of people love the idea of being a social enterprise, but they sometimes lose sight of the enterprise side of things. They really like the social but they forget, wait a second, this thing has to be profitable and sustainable in order to really have an impact. [Social] impact is tied to profit regardless of what people want to believe.

There is an obviousness to the idea that an entrepreneur should emphasize the business characteristics of his enterprise when communicating with financially minded investors; however, there is significant variance between social entrepreneurs in their possession of this narrative "competency". Sigma provides a stark example.

Sigma operates in the same space as Epsilon, one of the funding successes. Both firms created a tool that allows users to make donations to nonprofits by engaging in actions online (e.g. social media actions such as "liking" an item on Facebook, making a purchase on a website). However, Sigma's founder and CEO has not secured funding for his venture. The description he provides of his motivation for founding the venture may explain one reason for the lack of investment.

[Sigma] was created as a new revenue source for nonprofits. We're not a nonprofit. [But] Sigma was not created to make money for the company itself.

The CEO communicates his social mission (increasing donations) and his primary beneficiary group (nonprofits) but not a description of the business solution he offers to his primary customer group (i.e. corporations using his service for cause-marketing 
campaigns and to attract customers). Moreover, although he clarifies that he is not a nonprofit, he emphasizes that generating revenue for the company is not the venture's primary focus. When pressed about why it is important to communicate this fact, he emphasizes his long personal history working with nonprofits and again focuses on beneficiaries not customers. He explains:

After working with nonprofits for so long, the main reason for creating this was not to create cash flow. The main reason to create this was to create revenue for nonprofits. If not creating for nonprofits, it doesn't make sense to be around. Nonprofits are a key part. Actually, they are the key part of the model. If we take the nonprofit piece out of Sigma, there is no business.

In addition to trying to increase individual donations to nonprofits, Sigma also gives a substantial portion of the company's revenue to nonprofits. The CEO explains this practice and the pushback it has received.

Some people go 'wow, you're giving away over half of what's being brought in to Sigma - that's an awful lot. Most people are definitely saying 'why are you giving away so much? I've been told by quite a few people and organizations, 'you should be keeping $80 \%$ of everything that's coming in until you're stable... [But] I wanted the bar to be set high going into it because I believe in it. I believe the concept is completely sound. Certainly, if we'd been keeping $80 \%$ of [revenues], we probably would have been much closer to sustainability now, but the amount that we would have paid out to nonprofits wouldn't have been as much - and it wouldn't have been as exciting for them.

Despite acknowledging that this practice is detrimental to the financial sustainability of the business, the CEO communicates that helping nonprofits (i.e. the venture's social mission) takes priority. Interestingly, Sigma has a strong revenue model. However, their CEO does not leverage this fact in his communication and, as described, repeatedly reiterates that the goal of the venture is not to make money for the company. In this way, the CEO's pitch is very similar to the social entrepreneur described by Alpha's investor who demonstrated an equally underdeveloped business narrative by admitting "we don't 
know if we'll make money or not." This venture was viewed as a very unattractive investment. Sigma's overemphasis on the social good component and lack of business narrative has similarly hampered its ability to attract investors.

\section{Tailoring: Social-Good / Personal Narratives and Other Resource Providers}

Tailoring is based on evidence that successful social entrepreneurs emphasize different narratives with different resource providers. Thus far, I have provided evidence that successful entrepreneurs' construct well-developed business narratives and use them in communication with investors. However, if tailoring is indeed an important tactic then it is also necessary to present evidence that these entrepreneurs use non-business narratives with other audiences. That is, they do not simply communicate and emphasize a convincing business narrative with all resource providers.

There are audiences, such as the media and certain customer groups, which are influenced by the other two narrative-types. Indeed, as Alpha's CEO alluded, when communicating with non-investor resource providers, successful social enterprises "flip" their narrative emphasis: they focus primarily on their social-good and personal narratives and de-prioritize their venture's business narratives.

In communicating with the media, for instance, successful social entrepreneurs emphasize entirely different features of their venture than when communicating with investors. In particular, they craft narratives emphasizing the social-good themes described in detail in Chapter 5. Comparing the dominant themes in Alpha's business narrative with those in their media communications provides clear examples. 
As previously described, with investors Alpha's CEO communicates a narrative containing a business emphasis (e.g. "Don't let our name and the flower in our logo fool you, we are a business ...”). In contrast, with the media, she communicates and emphasizes being a social enterprise (e.g. "Alpha is a social venture, [...] I've built a tool to help people do good"). Similarly, the CEO's general description of the company emphasizes the business model when pitching to investors (e.g. "We [are] an online coordination platform $[\ldots]$ for corporations to reach people with their cause marketing messages") and the social mission when giving media interviews:

\begin{abstract}
What we do is we help improve the community volunteering experience. That's for people who are volunteering at the most local level, helping at their schools, helping with their Scout troops, helping with the small non-profit that might be running an after school mentoring program or a community garden or a soup kitchen out of a church.
\end{abstract}

The last two quotations also illustrate that there is a switch in the focal characters of the narratives. With investors, Alpha's CEO emphasizes the venture's primary customers (i.e. corporations); however with the media she emphasizes her beneficiary groups (i.e. several types of volunteers).

The business problem Alpha addresses is that corporations have a difficult time gaining advertising access to the primary user of its site: "affluent, influential moms". In contrast, the social problem Alpha targets is that "anyone who has volunteered knows about the difficulties in organizing groups of people — the frustrating process of backand-forth e-mails, phone calls and sign-up sheets. Good people sometimes drop out because it's a hassle." The CEO also uses similar verbiage ("secret sauce"/"special sauce") to communicate why the venture's solution to both the business and social problems are unique. Regarding the former, she explains: 
Our secret sauce is, it's primarily an affluent, influential mom that's organizing volunteering in her school, team, scouts, church, or health group. And she's highly, highly desirable to companies that want to reach her, brands that want to reach her, and she's very difficult to reach. Alpha aggregates her in one place. It's not an extra thing, like going on Facebook or Twitter, it's something that she actually has to do, 'cause parent volunteering isn't really volunteering, it's just your turn.

She describes the solution to the social problem in a media interview:

Alpha's special sauce is that anyone can launch a volunteer schedule and invite others to sign up to help - in a handful of minutes. Other volunteer management platforms require board approval, budget meetings and training to get started. However, $80 \%$ of nonprofits have just two paid staff members and a tremendous amount of volunteering happens more informally with committee chairs, corporate volunteer captains, and neighbors who don't have access to formal volunteer management software. Instead, they are left to Excel spreadsheets, email, and frustrating online groups to coordinate volunteers. We don't think it's right that people who raise their hands as a volunteer leader get saddled with cumbersome administrative duties to do their jobs.

Finally, analogous to communicating about the economic value generated by the venture, Alpha's CEO also emphasizes the social value they have created. She does so by describing the general social impact to her primary and secondary beneficiaries (e.g. "any mom that is organizing a group of volunteers or any person organizing a group of volunteers can do it much simpler with Alpha [and] non-profits [...] use us to coordinate their groups. We save them one to two man days a month in volunteer coordination time.)

She also communicates stories that highlight specific beneficiaries.

We have literacy programs that are now offered. They've gone from two programs to nine because we simplify their volunteering. We've got seasonal homeless shelters that they used to be open for two days. They're interfaith shelters that are now open five days a week because we take care of the volunteer coordination burden. (Founder; Alpha)

In summary, in communicating with the media Alpha's CEO emphasizes a social narrative constructed of themes (e.g. social venture emphasis, social problem, solution, impact) and characters (beneficiaries) that are analogues to those in the business narrative (e.g. business venture emphasis; business problem, solution, impact; customers). 
The three ventures classified as "unsuccessful" fail to engage in these tactics. For instance, evidence suggests that Sigma has not secured investment, in part, because it has failed to develop a business narrative. Instead, the CEO has developed a compelling social narrative, which he communicates to all audiences. As expected, this practice has not attracted investors, but the venture has received a large amount of media attention.

The other two ventures (Omega and Rho), however, have under-invested in developing compelling social narratives. Omega, for instance, created a way for individuals to donate to their favorite causes every time they engage in social media actions. They also help nonprofits to improve the efficiency of their fundraising campaigns. Yet, their CEO explains that he never really felt comfortable communicating about Omega using the labels "social enterprise" and "social entrepreneurship" or with developing a narrative that frames his business in that way.

\footnotetext{
You know, when I go to social enterprise type meet-ups, most of the ventures seem like a perfect fit for the evening - the language that's being used and the kind of things people are talking about. Like, "We want to develop a wind power solution for rural farms in India... we want to develop cheap prosthetic devices for poor people in Africa." I don't use that language [social enterprise] because I view us as infrastructure.
}

Omega's business model puts it squarely within what is referred to as the "social media for social good" space, which is occupied by dozens of social ventures and individuals who classify themselves as "social entrepreneurs". Thus, the venture could easily be pitched as a social enterprise. The CEO's insistence that the venture is just "infrastructure" for the nonprofit community and that it simply manages nonprofits and donors “transaction process" severely limits the firm's ability to develop a social mission- 
focused narrative. This is associated with Omega receiving significantly less media attention than other firms in its space that communicate compelling social narratives.

\section{The Role of the Personal Narrative}

As explained in Chapter 5, personal narratives are constructed from entrepreneurs' backgrounds and experiences. They are often drawn from the entrepreneurs' life narrative (McAdams, 1999). On the surface this makes them idiosyncratic to the individual; however, on a deeper, structural level they share recurring themes and character-types. Common themes include descriptions of work and non-work experiences, beliefs and values, significant events (such as epiphany moments and exposure to the social problem), and struggles.

When communicating with media members the successful social enterprises gave priority to communicating their social narratives, however, they also made use of their personal narratives. All five successful ventures engaged in this practice, while only one of the unsuccessful ventures did so. One of the clearest examples of this practice is found in the media communication of Lambda.

Lambda was initially unsuccessful in acquiring external investment. Shortly before the end of the data collection period of the study, however, they delivered a pitch to, and were accepted into, a technology incubator. A few months later, they received a round of angel investment.

Lambda underwent another important change over the course of the study: their CEO began to incorporate his personal narrative into the company's communication with the media. The social enterprise provides a search engine that aggregates social-service 
assistance programs. In communicating with the media, the company's founder and CEO weaves several significant personal experiences into his narratives. For instance, he often begins media interviews by explaining that, "Lambda was the child of about a dozen life experiences." In particular, there are three that he focuses on.

First, the CEO often communicates that his first exposure to government assistance programs was as a child.

I can still remember lining up for lunch in elementary school. I would dilly-dally and always be the last kid in line. I did this every day. You have to get creative figuring out how to be the last one all of the time. You tie your shoes. You act like you forgot something. I knew all the tricks. I didn't want my classmates to know that I was getting free lunch. In New York, it was obvious if you had free lunch. You didn't give the lunch lady money - kids with free lunch had brightly colored cards that were kept on the wall behind her. You would have to tell her your number. It held up the whole line - for what seemed like an eternity.

Second, he transitions into his most significant work experiences.

I spent four years improving access to human services as a consultant for the state. I read reports, analyzed business processes, and implemented improvements. I helped reform the way they administered the eligibility process for SNAP, Medicaid, and TANF. The projects I managed helped save the state more than $\$ 5$ million per year in operational costs.

Third, he describes his most personal inspiration for the business, an illness his mother

suffered that exposed him to inefficiencies in how social services are organized and

distributed.

Lambda was an idea that took ten years, but it started with my mom. I became my mother's guardian in 2002. In 1992 she had brain damage as a result of a bad case of Encephalitis. She lost most of her memory. I was 17 years old at the time and she came home from the hospital not knowing my name. My dad took care of her for a long time, but he got sick too and couldn't continue - she needed 24hour care. Through that experience I came to learn that there are services available, but they were very difficult to track down.

All three elements of his personal narrative communicate that the CEO has intimate experience with the social problem and with coming up with solutions to address it. Moreover, the way he describes the experiences to media members suggests an ultimate 
and underlying purpose guiding and connecting all of the experiences of his life. The narrative is, thus, teleological in that all of the events lead to a final culmination, which makes sense of and unites everything that has transpired before.

The CEO initially did not see the value in communicating personal experiences to the media. Instead, in early media interviews he chose to focus on the business. However, advice from a consultant who worked with the company on its marketing and media strategies and from mentors at a social enterprise accelerator program, helped him to see the value in communicating his personal narrative. The consultant explains the power of the CEO's personal stories.

But [the CEO] had a great story, his personal story, his mom and taking care of his mom, and working at the state for as long as he did and quitting that because he saw these inefficiencies in state government and how they case managed and then going out and forming his own software. People love that story, reporters eat that up and we got a lot of coverage.

A description by the CEO of how the company came to be featured in a major national news publication suggests that the consultant is correct in his assessment of the power of CEO's personal narrative.

And then I got an introduction to a [reporter], who is the technology writer at The Times. And he wrote a feature because he's kind of tired of writing about just the next new product. And I guess it's an easy subject to write about: the fact that I had some experience with these programs as a kid, there's a story there, right. And then it's just sort of snowballed on itself.

Despite significant success in attracting media attention, the CEO admits that he really has not prioritized having a media strategy. The consultant, for instance, only worked for the company for a very brief period. The CEO states, "oh my gosh, I wish I could say I had a [media] strategy" (original emphasis). He also explains that he never issues press releases and that, in fact, the media pursues him. This suggests that a powerful personal 
narrative can perhaps overcome an under-investment in media "resources" and can generate significant media attention.

Lambda's success in incorporating the CEO's personal narrative into communication with the media can be contrasted with the experiences of Omega, one of the three unfunded social enterprises. Omega's founders chose not to include their personal experiences in the narratives they communicated to the media (and to customers). The founder and original CEO was asked if she had ever contemplated doing so, her answer seemed to suggest that she did not find this practice appropriate. She explained, “As far as making ourselves more visible [...], I don't know that we, I'm not sure any founders think, 'I'm going to make myself the focus..."'

So, rather than developing the personal narrative of one of the venture's three founders, they instead decided to create a series of cartoonish characters, or "avatars", that were the focus of the narrative they communicated to the media. One of the cofounders, the venture's second CEO, explains, “[Omega] was less about [the founders] and more about whatever our crazy avatars were." They developed half a dozen characters (e.g. a samurai), each with different personalities. The fictional details of these characters became the focus of their communication. The founders believed that these characters would be appealing to the media and to customers. In particular, they hoped that users of the site would incorporate the characters in their social media (e.g. as their Twitter profile pictures), which would generate interest in the company. However, the practice never caught on and, in fact, they received limited media attention.

Summary: Social-Good and Personal Narrative Tailoring 
Entrepreneurs from all five successful social enterprises developed and communicated compelling social-good and personal narratives. Moreover, with noninvestor resource providers, such as the media, they tailored their communication to emphasize these narratives. These entrepreneurs recognized that their social and personal narratives could serve a valuable purpose. Indeed, entrepreneurs associated with each of these ventures conveyed a common belief: that although there are a number of challenges to being a social enterprise, if the entrepreneur is savvy about communicating about their social-good and personal narratives then getting media attention is not difficult. For instance, the founder and CEO of Gamma, who is a serial non-social entrepreneurs, says, “I've had to pay for a lot of PR before, but with this one [Gamma], we don't pay anything and it just keeps coming." Similarly, Epsilon's founder describes his experience getting media attention as a social enterprise.

\footnotetext{
As a [traditional] start-up you end up sending out 20 press releases, maybe the 16 th will get something notable. We send out a press release, the next Tuesday we're interviewed by the Huffington Post. They love this space. The press loves this space. (Epsilon; Founder1)
}

However, the lack of attention that the media has given to Rho and Omega suggest that, like investors, the press does not "love" all firms in the social enterprise space. Instead, gaining media resources, like gaining financial resources, depends in part on communicating the right narrative to the right audience.

\section{Summary}

This chapter presents evidence that the social entrepreneurs successful in attracting external investment engaged in a common narrative tactic: tailoring. When communicating with different resource provider groups, these entrepreneurs adapted the 
emphasis of their narratives to match the interests of their audiences. Specifically, when communicating with investors, successful entrepreneurs emphasized elements of their business narratives. When communicating with the media, they emphasized elements of their social-good and personal narratives. In contrast, the unsuccessful social entrepreneurs did not engage in narrative tailoring. Instead, they communicated the same narrative-type (usually the social-good narrative) to all groups of resource providers.

It is important to point out, however, that the successful social enterprises did not use only their business narratives with investors or only their social-good and personal narratives with other stakeholder groups. Their communication prioritized and emphasized one narrative type over the others depending on the group; however they used elements of all three narratives. With investors, successful social enterprises emphasized their business narratives while also incorporating elements of their social and personal narratives. With the media, they "flipped" their emphasis and focused on personal and social-good narratives while moving their business narrative to a subordinate role. Figure 1 provides a graphical representation of narrative tailoring (the figure is elaborated on in subsequent chapters) 


\section{FIGURE 1:}

\section{NARRATIVE TAILORING}

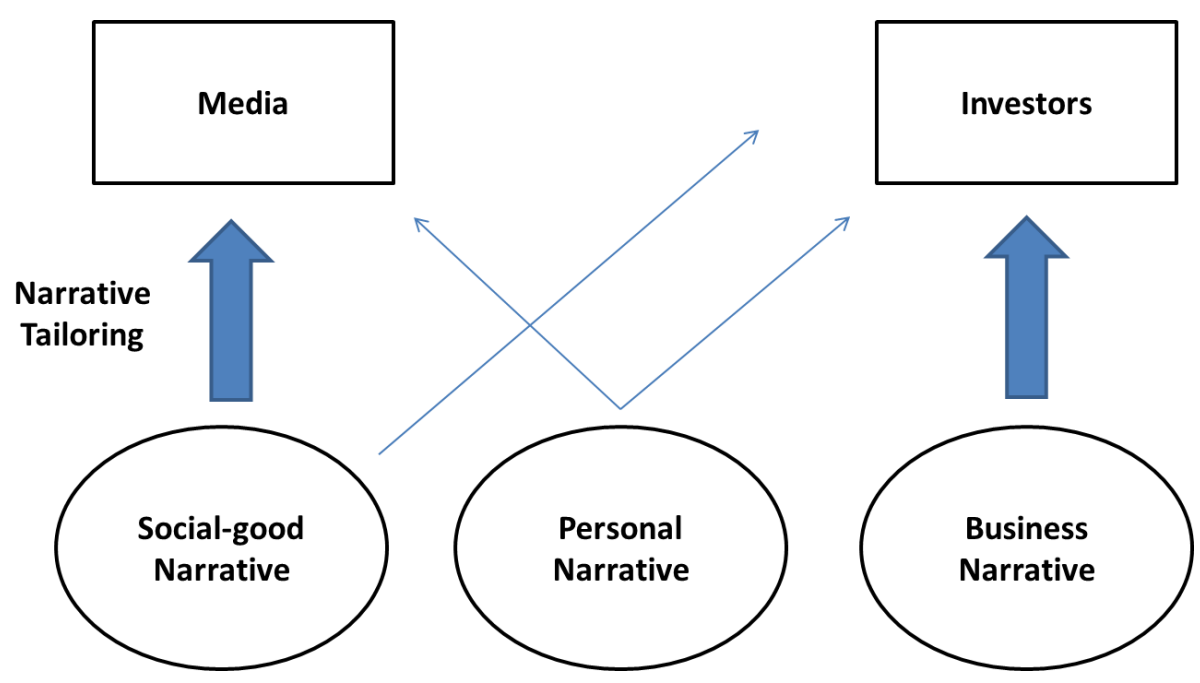

Effective tailoring involves knowing what narrative to emphasize with a particular audience. It does not involve communicating one narrative-type and entirely excluding the other two. Indeed, in addition to tailoring, the successful social enterprises engaged in another, narrative-related tactic: they created linkages between narrative-types. For instance, with investors, the successful social ventures tied elements of their social-good and personal narratives to a dominant business narrative. This practice of combining (or linking) narratives is the subject of the next chapter. 


\section{CHAPTER 7:}

\section{HOW DO SOCIAL ENTREPRENEURS USE NARRATIVES TO ACQUIRE RESOURCES?}

\section{Narrative Linking}

The successful social enterprises did not tell business, social-good, or personal narratives in isolation. Instead, they crafted complex communication that, depending on the audience, prioritized a primary narrative while incorporating elements of the other narrative-types. These interdependencies between narratives are created by linking the three narrative-types. Linking is defined as connecting elements of more than one narrative-type. As the evidence below suggests, this tactic can make narrative communication more compelling.

Linking is most evident in successful social entrepreneurs' communication with investors. In such communication, they do not focus exclusively on their business message. Instead, they link multiple narrative-types by including themes from the personal and social-goods narratives. The other narrative-types are, however, a secondary (or tertiary) emphasis.

Evidence from social entrepreneurs and resource providers is discussed. First, evidence is presented that successful social enterprises engaged in narrative linking while unsuccessful ventures did not. Second, evidence is presented that while investors focus on entrepreneurs' business narratives, they are also influenced, often in subtle ways, by social-good and personal narratives. Table 9 provides support for these findings and summarizes the use of narrative linking for each case. 
TABLE 9:

NARRATIVE LINKING

\begin{tabular}{|c|c|c|c|c|}
\hline COMPANY & $\begin{array}{c}\text { BUSINESS / } \\
\text { SOCIAL } \\
\text { LINKING }\end{array}$ & $\begin{array}{c}\text { BUSINESS / } \\
\text { PERSONAL } \\
\text { LINKING }\end{array}$ & $\begin{array}{c}\text { SOCIAL / } \\
\text { PERSONAL } \\
\text { LINKING }\end{array}$ & $\begin{array}{l}\text { LINKING ALL } \\
3 \text { NARRATIVES }\end{array}$ \\
\hline $\begin{array}{c}\text { FUNDED } \\
\text { VENTURES } \\
\text { Alpha }\end{array}$ & $\begin{array}{l}\text { Social problem } \\
\text { solution; Description } \\
\text { of Business model. } \\
\text { "What we do is we } \\
\text { make it very easy for } \\
\text { people to volunteer by } \\
\text { making it very easy for } \\
\text { them to sign up to } \\
\text { volunteer. So that } \\
\text { makes us the social part } \\
\text { of our social venture. } \\
\text { What makes up the } \\
\text { venture part is who's } \\
\text { actually doing the } \\
\text { volunteering. Women, } \\
\text { moms, between the } \\
\text { ages of } 35 \text { and } 50 \text { [...] } \\
\text { And so we found a way } \\
\text { to aggregate these } \\
\text { moms while they are } \\
\text { doing good [...] and we } \\
\text { give brands the highly } \\
\text { targeted access to these } \\
\text { moms. It's really a do } \\
\text { good and make money } \\
\text { venture." } \\
\text { (Founder/CEO) }\end{array}$ & $\begin{array}{l}\text { Prior experiences - } \\
\text { work; Founder } \\
\text { business strengths. } \\
\text { "Before starting } \\
\text { Alpha, I was a } \\
\text { consultant helping } \\
\text { organizations improve } \\
\text { leadership practices, } \\
\text { and business } \\
\text { processes. Essentially, } \\
\text { I'm an expert in } \\
\text { helping organizations } \\
\text { improve their } \\
\text { performance and } \\
\text { better meet customer } \\
\text { needs." } \\
\text { (Founder/CEO) }\end{array}$ & $\begin{array}{l}\text { Personal exposure to } \\
\text { social problem; } \\
\text { Social-problem } \\
\text { general description. } \\
\text { "So I was a school } \\
\text { volunteer and a } \\
\text { working mom and I } \\
\text { kept noticing that my } \\
\text { Blackberry was } \\
\text { filling up with reply } \\
\text { all e-mail request } \\
\text { over whose turn it } \\
\text { was to help at table } \\
\text { time or help at recess. } \\
\text { And the more I talked } \\
\text { to working moms, we } \\
\text { were all overwhelmed } \\
\text { with the commun- } \\
\text { ication about } \\
\text { volunteering. And } \\
\text { then I would talk to } \\
\text { the moms who are } \\
\text { PTA leaders and they } \\
\text { were upset that it was } \\
\text { always the same } \\
\text { people helping all the } \\
\text { time." } \\
\text { (Founder/CEO) }\end{array}$ & $\begin{array}{l}\text { Personal exposure to } \\
\text { social problem; } \\
\text { Social-problem } \\
\text { general description; } \\
\text { Attractiveness of } \\
\text { market. } \\
\text { "I was flying to } \\
\text { Dallas, and I had } 45 \\
\text { reply e-mails over } \\
\text { whose turn it was to } \\
\text { help at table time, } \\
\text { [...], and thought, } \\
\text { 'This has got to end.' } \\
\text { The Federal Reserve } \\
\text { was one of my clients } \\
\text { up there. And so I } \\
\text { [...] learned that in a } \\
\text { mom audience - } \\
\text { that's a distributed } \\
\text { audience - there's no } \\
\text { boss. There really } \\
\text { wasn't any software } \\
\text { that would work in a } \\
\text { distributed } \\
\text { environment. And so, } \\
\text { I had done a lot of } \\
\text { consumer } \\
\text { benchmarking studies } \\
\text { and market } \\
\text { benchmarking } \\
\text { studies, and so I just } \\
\text { started characterizing } \\
\text { the market and } \\
\text { realized, you know, } \\
\text { 'Hey, there's a hole } \\
\text { here."” } \\
\text { (Founder/CEO) }\end{array}$ \\
\hline
\end{tabular}


TABLE 9 (cont.)

\begin{tabular}{|c|c|c|c|c|}
\hline Beta & $\begin{array}{l}\text { Business model; Social } \\
\text { impact. } \\
\text { "Beta allows } \\
\text { consumers to convert } \\
\text { any unused points or } \\
\text { miles into donations to } \\
\text { any one of millions of } \\
\text { global charities, which } \\
\text { opens a new option for } \\
\text { loyalty marketing } \\
\text { program managers to } \\
\text { both reach consumers } \\
\text { and clear unused points } \\
\text { from their } \\
\text { books." } \\
\text { (Founder/CEO) }\end{array}$ & $\begin{array}{l}\text { Prior experiences - } \\
\text { work; Business } \\
\text { problem addressed. } \\
\text { "Starting Beta } \\
\text { redefined my career } \\
\text { trajectory. I spent the } \\
\text { past decade in the } \\
\text { consulting realm. } \\
\text { I realized [...] it's } \\
\text { very difficult for } \\
\text { brands or } \\
\text { companies to really } \\
\text { justify the value of } \\
\text { their giving or } \\
\text { of their social } \\
\text { responsibility in } \\
\text { supporting nonprofits. } \\
\text { So this became a } \\
\text { passion of mine. I } \\
\text { wanted to dig in } \\
\text { deeper to really } \\
\text { understand [...] how } \\
\text { can we find ways to } \\
\text { measure and monetize } \\
\text { the value of that } \\
\text { giving?" } \\
\text { (Founder/CEO) }\end{array}$ & $\begin{array}{l}\text { Prior experiences- } \\
\text { work; Social problem } \\
\text { description. } \\
\text { "More than a decade } \\
\text { of work in the } \\
\text { nonprofit sector made } \\
\text { it evident to me the } \\
\text { divide between } \\
\text { charitable causes and } \\
\text { the power of business } \\
\text { community was } \\
\text { massive, and the } \\
\text { programs to close the } \\
\text { gap didn't exist. } \\
\text { Today there is greater } \\
\text { pressure for the } \\
\text { government not to } \\
\text { provide services, } \\
\text { while charities and } \\
\text { nonprofits, which are } \\
\text { supposed to fill in the } \\
\text { gap, are receiving } \\
\text { less money." } \\
\text { (Founder/CEO) }\end{array}$ & $\begin{array}{l}\text { Prior experiences; } \\
\text { Founder business } \\
\text { strengths; Social } \\
\text { problem description. } \\
\text { "In my previous } \\
\text { career I was a special } \\
\text { advisor to the U.N. } \\
\text { [...] worked for the } \\
\text { remote aboriginal } \\
\text { community and } \\
\text { advising African } \\
\text { governments in the } \\
\text { field of local } \\
\text { economic } \\
\text { development. In that } \\
\text { process I was always } \\
\text { bringing together } \\
\text { stakeholders from } \\
\text { governments, the } \\
\text { nonprofit community } \\
\text { and the private } \\
\text { sector. [...] we } \\
\text { noticed that the } \\
\text { missing link was the } \\
\text { way the business } \\
\text { community and the } \\
\text { nonprofit community } \\
\text { work together." } \\
\text { (Founder/CEO) }\end{array}$ \\
\hline
\end{tabular}


TABLE 9 (cont.)

\begin{tabular}{|c|c|c|c|c|}
\hline Epsilon & $\begin{array}{l}\text { Business model; Social } \\
\text { impact. } \\
\text { Once a Fundraiser is } \\
\text { defined and enabled, } \\
\text { the platform's } \\
\text { underlying patented } \\
\text { technology takes care } \\
\text { of the rest, triggering } \\
\text { the specified donation } \\
\text { at the pre-defined } \\
\text { intervals for the life of } \\
\text { the Fundraiser. This } \\
\text { can ultimately } \\
\text { transform a one dollar } \\
\text { donation into millions. } \\
\text { (Co-founder/CEO1) }\end{array}$ & $\begin{array}{l}\text { Prior work } \\
\text { experiences; Founder } \\
\text { business strengths. } \\
\text { "And then Epsilon } \\
\text { kind of came along. It } \\
\text { was an idea among a } \\
\text { couple of friends and } \\
\text { it just sang to me. } \\
\text { Because part of the } \\
\text { big reason I left IBM } \\
\text { is that I was really } \\
\text { burned out spending } \\
\text { all of my effort to } \\
\text { help some guy make } \\
\text { another dollar when I } \\
\text { really wanted to spend } \\
\text { my effort changing } \\
\text { the world in some } \\
\text { positive way. That's } \\
\text { why I went to the } \\
\text { government because I } \\
\text { helped make America } \\
\text { safer" (Co- } \\
\text { founder/CEO1) }\end{array}$ & $\begin{array}{l}\text { Personal exposure; } \\
\text { social problem } \\
\text { description. } \\
\text { "When my daughter } \\
\text { was born, the March } \\
\text { of Dimes had donated } \\
\text { to the hospital that } \\
\text { very day the machine } \\
\text { she needed to live. I } \\
\text { literally saw them } \\
\text { unpack the wrapper. I } \\
\text { realized then how } \\
\text { important real cash is } \\
\text { [for nonprofits]." } \\
\text { (Co-founder/CEO2) }\end{array}$ & $\begin{array}{l}\text { Prior experiences; } \\
\text { social problem } \\
\text { description; Founder } \\
\text { business strengths. } \\
\text { "It's way more than } \\
\text { just a business for } \\
\text { our whole team. [...] } \\
\text { Post-college, my wife } \\
\text { and I ended up in } \\
\text { Europe for a couple } \\
\text { of years assisting } \\
\text { refugees and } \\
\text { immigrants. Anyone } \\
\text { that's ever worked } \\
\text { with a nonprofit or } \\
\text { charity has said } \\
\text { things like "If only } \\
\text { we had this cash, we } \\
\text { could ..." and while } \\
\text { overseas, we } \\
\text { definitely had our } \\
\text { share of those } \\
\text { moments. [...] I } \\
\text { spent about six years } \\
\text { with IBM, working } \\
\text { on analyzing threats } \\
\text { to the Internet at } \\
\text { large. I left there to } \\
\text { work with the } \\
\text { (Department of } \\
\text { Defense) Computer } \\
\text { Emergency Response } \\
\text { Team. I realized I } \\
\text { [...] really wanted } \\
\text { was to take my } \\
\text { technology } \\
\text { experience and apply } \\
\text { it in a much bigger } \\
\text { way - doing } \\
\text { something that could } \\
\text { fundamentally } \\
\text { change the world. }\end{array}$ \\
\hline
\end{tabular}


TABLE 9 (cont.)

\begin{tabular}{|c|c|c|c|c|}
\hline Gamma & $\begin{array}{l}\text { Business case for } \\
\text { venture; Social impact. } \\
\text { "Consumers save } \\
\text { money, restaurants get } \\
\text { clients when they need } \\
\text { them most, and a } \\
\text { growing societal issue } \\
\text { is solved. So this is a } \\
\text { business that generates } \\
\text { an incredible amount of } \\
\text { revenue, but still does } \\
\text { good for the } \\
\text { community, and } \\
\text { effectively, we can } \\
\text { eliminate hunger, at } \\
\text { least in the U.S." } \\
\text { (Founder/CEO) }\end{array}$ & $\begin{array}{l}\text { Personal } \\
\text { experiences; } \\
\text { Business problem } \\
\text { addressed. } \\
\text { "The idea came from } \\
\text { the college exploits of } \\
\text { my partner [...]. Like } \\
\text { many young men, he } \\
\text { wanted to take women } \\
\text { out to eat but could } \\
\text { not afford it. He } \\
\text { noticed there were } \\
\text { times when } \\
\text { restaurants had empty } \\
\text { tables, and he thought } \\
\text { about a service to fill } \\
\text { the most expensive } \\
\text { table: the empty one." } \\
\text { (CSO) }\end{array}$ & $\begin{array}{l}\text { Exposure to social } \\
\text { problem; Social } \\
\text { problem description. } \\
\text { "You hit that } 40 \text {-year } \\
\text { old mark and your } \\
\text { DNA changes [...] } \\
\text { you get to a point } \\
\text { where you start } \\
\text { saying, "It's time to } \\
\text { give back." And I } \\
\text { discovered a problem. } \\
{[\ldots . .] \text { And I found out }} \\
\text { last August that we } \\
\text { have } 42 \text { million } \\
\text { Americans on food } \\
\text { stamps, which was } \\
\text { absolutely unknown } \\
\text { to me. When we think } \\
\text { about hunger, } \\
\text { including me, we live } \\
\text { in a bubble. So in } \\
\text { December I started } \\
\text { volunteering at a } \\
\text { place called Alliance } \\
\text { Food Pantry." } \\
\text { (Founder/CEO) }\end{array}$ & No evidence \\
\hline Lambda & $\begin{array}{l}\text { Attractiveness of } \\
\text { market; Social } \\
\text { problem description. } \\
\\
\text { "Lamba is a [...] } \\
\text { simple idea. There are } \\
1.4 \text { million } \\
\text { governments, charities } \\
\text { and congregations that } \\
\text { administer human } \\
\text { service programs in the } \\
\text { US. [...] Yet no } \\
\text { marketplace exists. } \\
\text { Each of these } \\
\text { organizations are } \\
\text { marketing their } \\
\text { services, eligibility } \\
\text { systems and } \\
\text { administering these } \\
\text { programs. [...] } \\
\text { (Founder/CEO) }\end{array}$ & $\begin{array}{l}\text { Prior work } \\
\text { experiences; Founder } \\
\text { business strengths. } \\
\\
\text { "I spent } 4 \text { years } \\
\text { improving access to } \\
\text { human services as a } \\
\text { consultant for the } \\
\text { State of Texas. I read } \\
\text { reports, analyzed } \\
\text { business processes } \\
\text { and implemented } \\
\text { improvements. [...] I } \\
\text { learned that the } \\
\text { process for finding } \\
\text { and applying for } \\
\text { services is hard work, } \\
\text { too complicated, and } \\
\text { did not serve clients." } \\
\text { (Founder/CEO) }\end{array}$ & $\begin{array}{l}\text { Exposure to social } \\
\text { problem; social } \\
\text { problem description. } \\
\text { "Through that } \\
\text { experience I came to } \\
\text { understand the lack of } \\
\text { services available for } \\
\text { severely ill, especially } \\
\text { if you're low-income. } \\
\text { There is a gap, a huge } \\
\text { gape, and caretakers, } \\
\text { like my family, are } \\
\text { left with little options. } \\
\text { We have tons of great } \\
\text { programs, but access } \\
\text { and service is still } \\
\text { low in some places." } \\
\text { (Founder/CEO) }\end{array}$ & $\begin{array}{l}\text { Attractiveness of } \\
\text { market; Prior work / } \\
\text { non-work experience } \\
\text { "So it's a big market. } \\
\text { Why are we looking } \\
\text { to actually deliver? } \\
\text { I've been working on } \\
\text { these problems for } \\
\text { the last } 10 \text { years. I } \\
\text { started out as a } \\
\text { programmer and } \\
\text { applicator, and went } \\
\text { back to graduate } \\
\text { school after my mom } \\
\text { - after I became my } \\
\text { mother's guardian." } \\
\text { (Founder/CEO) }\end{array}$ \\
\hline
\end{tabular}


TABLE 9 (cont.)

\begin{tabular}{|c|c|c|c|c|}
\hline $\begin{array}{c}\text { UNFUNDED } \\
\text { VENTURES } \\
\text { Rho }\end{array}$ & $\begin{array}{l}\text { No evidence of a link } \\
\text { between the social- } \\
\text { good and business } \\
\text { narratives. }\end{array}$ & $\begin{array}{l}\text { No evidence of a } \\
\text { developed personal } \\
\text { narrative that can be } \\
\text { linked to the venture's } \\
\text { business narrative. }\end{array}$ & $\begin{array}{l}\text { Social impact. Prior } \\
\text { experiences. } \\
\text { "Our vision is to } \\
\text { make it easier for } \\
\text { non-profits to do } \\
\text { more good [...] We } \\
\text { believe that making } \\
\text { this vision a reality is } \\
\text { worth having quit our } \\
\text { lucrative jobs and } \\
\text { living off our } \\
\text { savings." (Co- } \\
\text { founder; CEO) }\end{array}$ & $\begin{array}{l}\text { No evidence of } \\
\text { linking all three } \\
\text { narrative-types. }\end{array}$ \\
\hline Sigma & $\begin{array}{l}\text { Does not communicate } \\
\text { a developed business } \\
\text { narrative, which } \\
\text { hampers linking } \\
\text { business and social- } \\
\text { good narratives. }\end{array}$ & $\begin{array}{l}\text { Does not } \\
\text { communicate a } \\
\text { developed business } \\
\text { narrative; personal } \\
\text { narrative is only semi- } \\
\text { developed; both } \\
\text { hamper linking } \\
\text { business and personal } \\
\text { narratives. }\end{array}$ & $\begin{array}{l}\text { Social impact; } \\
\text { Personal epiphany. } \\
\text { "I realized this is } \\
\text { when I'm supposed to } \\
\text { be making the most } \\
\text { money in my life, but } \\
\text { whether it's altruism } \\
\text { or whatever it is, I'm } \\
\text { going to take this } \\
\text { time now, and I'm } \\
\text { going to figure out } \\
\text { how to do something } \\
\text { more beneficial for } \\
\text { the community at } \\
\text { large. } \\
\text { (Founder/CEO) }\end{array}$ & $\begin{array}{l}\text { No evidence of } \\
\text { linking all three } \\
\text { narrative-types. }\end{array}$ \\
\hline Omega & $\begin{array}{l}\text { Limited social-good } \\
\text { and business narratives. } \\
\text { No evidence of linking. }\end{array}$ & $\begin{array}{l}\text { No personal narrative, } \\
\text { which makes linking } \\
\text { business and personal } \\
\text { narratives not } \\
\text { possible. }\end{array}$ & $\begin{array}{l}\text { No personal narrative, } \\
\text { which makes linking } \\
\text { social-good and } \\
\text { personal narratives } \\
\text { not possible. }\end{array}$ & $\begin{array}{l}\text { No evidence of } \\
\text { linking all three } \\
\text { narrative-types. }\end{array}$ \\
\hline
\end{tabular}

\footnotetext{
${ }^{15}$ It is difficult to provide succinct evidence illustrating that the narratives of social enterprises not receiving funding did not contain narrative linking because often an entire pitch or the entire text of a narrative is evidence of "non-linking" (i.e. narratives told in isolation). There are, however, very few examples of unsuccessful cases engaging in linking.
} 


\section{Entrepreneurs and Narrative Linking (Evidence)}

Narrative linking involves combining two or more of a social enterprise's three narrative "building blocks" (i.e. personal, social-good, and business narratives). Each of the three narrative-types can be linked with another of the narrative-types or all three can be used in consort. Examples from Gamma's and Beta's communication can be used to illustrate each of the four combinations of narratives. First, business and social-good narratives can be linked. For instance, Gamma's CEO states that when he pitches the venture to investors he likes to explain,

It's a win-win for both sides. We win a transaction or success fee from the restaurant every time we bring a consumer in, and then we take a portion of it and we feed hungry people with it so that when you eat, they eat. Consumers save money, restaurants get clients when they need them most, and a growing societal issue is solved. So this is a business that generates an incredible amount of revenue, but still does good for the community, and effectively, we can eliminate hunger, at least in the U.S.

This quotation highlights elements of the business narrative, such as the venture's revenue model ("a transaction fee from the restaurant"), strengths of the venture ("generates an incredible amount of revenue"), and the primary customers groups ("consumers", "restaurants"). It also contains elements of the venture's social narrative, such as the social problem targeted (the U.S. hunger problem) and the primary beneficiaries ("hungry people").

Second, elements of business and personal narratives can be combined. For instance, the Chief Strategy Office of Gamma used a linked narrative to explain the inspiration for the business side of the venture.

The idea came from the college exploits of my partner, the company's Founder/CEO. He was a student at the University of Toronto, working his way through school playing jazz piano. Like many young men, he wanted to take women out to eat but could not afford it. He noticed there were times when 
restaurants had empty tables, and he thought about a service to fill the most expensive table: the empty one.

In combining elements of the personal and business narrative, this piece of communication can serve several functions. First, regarding the business narrative, it reinforces the business problem being addressed (i.e. restaurants suffer from an "empty table" problem). It also touches on a consumer "pain point" (i.e. that dining out can be expensive) and suggests that the company has a solution for these problems. Regarding the personal narrative, the CEO's university is mentioned by name perhaps to emphasize the quality of his educational background. By describing that he was "working his way through school" signals the CEO's industriousness and work-ethic. The fact that he did so playing jazz piano is not relevant to the business, but it is unique, memorable, and interesting. Finally, by describing the CEO's own struggles (“...could not afford it”) he is conveying that the CEO has personal experience with both the consumer and business problems.

Third, elements of personal and social narratives can be combined. Gamma's CEO does this in his description of the inspiration behind the social-good component of his venture.

You hit that 40-year old mark and your DNA changes because although we're capitalists and you want to make as much money as you can, you get to a point where you start saying, "It's time to give back." And I discovered a problem. I met a guy named, Ken Kragin. Ken is responsible for pulling "We are the World" together. Ken is a very famous character in Hollywood. At one point he managed about $49 \%$ of the Billboard 100. And I was talking to Ken and I said, "Hey, I'm doing this [Gamma] and I said, "we're going to take a meal for every meal purchased and donate it to a kid in Africa." And he was shocked, he said, "You know we have a bigger problem in America." I said, "Yeah right." So he introduced me to a bunch of people including some very nice celebrities who are dealing with hunger, including Bruce Springsteen and people that manage Oprah's accounts, etc. And I found out last August that we have 42 million Americans on food stamps, which was absolutely unknown to me. When we 
think about hunger, including me, we live in a bubble. So in December I started volunteering at a place called Davis Food Pantry.

Like the previous two passages, this piece of communication can serve many purposes. Most explicitly, the CEO communicates several elements of the venture's social narrative, including the extent of the social problem and misconceptions about it. Moreover, he also includes elements of his personal narrative, such how he came to learn about the problem and to understand his own mistaken beliefs. More subtly, this piece of communication also conveys other pieces of information. For instance, it suggests that not only is the CEO well connected, but his social network includes celebrities (e.g. Kragin, Springsteen). Lastly, the food pantry that he mentions is actually one of the venture's largest nonprofit partners; so the CEO's volunteering represents a direct link to the company's primary beneficiary group.

Finally, entrepreneurs can unite elements of all three narrative types, as Beta's CEO does in the following description of his venture.

\begin{abstract}
In my previous career I was a special advisor to the U.N. I had my own consultancy, worked for the remote aboriginal community and advising African governments in the field of local economic development. In that process I was always bringing together stakeholders from governments, the nonprofit community and the private sector. [...] we noticed that the missing link was the way the business community and the nonprofit community work together. By offering consumers an easy way to support the causes important to them, charities around the world will gain new revenue streams while loyalty programs can build more meaningful and engaging relationships with their members.
\end{abstract}

Pertaining to the CEO's personal narrative, this communication suggests that he possesses a unique combination of work experiences, which make him well-suited to understand and tackle the complex problems the venture is addressing. In particular, the CEO makes a point of explaining that he has past experience bringing together very 
different stakeholder groups, which is a critical element in the enterprise's current activities. In this passage, he also highlights the social problem ("the missing link...") and previews their social and business solution ("By offering consumers...”). Finally, he communicates the social good created ("charities around the world will gain...") and the benefit to customers, which in this case is corporations with loyalty programs.

The previous examples illustrate that links can be created between social enterprise narratives. They also illustrate the types of information that are conveyed in these linked narratives and are suggestive of why the entrepreneur may be combining elements of different narrative-types. These examples do not, however, demonstrate how these linked narratives are deployed, nor do they provide direct evidence of how resource providers are influenced by them. Thus, it is important to understand how entrepreneurs conceive of using linked narratives and how audiences receive them. The section that follows provides this evidence. Given the focus of the study, emphasis is placed on how social entrepreneurs use linked narratives with investors and on how investors interpret them.

\section{Why Do Social Entrepreneurs Use Linked Narratives?}

Although successful social entrepreneurs know to emphasize a business narrative in communications with investors, they also (consciously) introduce elements of their personal and social-good narratives into such conversations. They do so because, as several of the successful entrepreneurs suggest, the social narrative may add incremental value, above and beyond the business case for the venture. Thus, while it is not thought to 
be a dominant influence on investors' overall decisions, it is thought to help sway a decision.

Entrepreneurs' describe the relationship between the business and social-good narratives using several similar metaphors. They describe the social narrative as the "icing on the cake", the "cherry on top", and the "gravy on top". For instance, the CEO of Gamma explains his approach to incorporating the social-good narrative in pitches. $\mathrm{He}$ states, "as I'm pitching investors, I start with the business solution first. But then there's nothing wrong with adding the gravy on top, which is the hunger piece [the social problem]." Gamma's CSO expresses a similar viewpoint. He states that the social-good message perhaps serves to "put you over the bar, or gets [an investor] to invest a little bit more than they would have, but I think it's probably closer to a tiebreaker than something that has a black and white influence."

If the social-good narrative does not have a "black and white influence," then how might it influence investors? The statements of successful entrepreneurs suggest that it serves three functions. First, the social-good narrative can grab investor's attention. As the co-founder and current CEO of Epsilon explains,

"For an investor to say "yes" or "no", I don't know if it [the social-good message] sways anybody. But I think it can be an attention-grabber maybe to look into us a little bit more. I don't think it sways their [overall] decision to invest. I think it sways their decision to do a little bit more homework than maybe they would have originally.

Alpha's CEO explained why it is important to stand out while pitching, "the thing to remember is investors see hundreds of pitches." Thus, improving the memorability of a pitch is suggested to improve the venture's chance of receiving investment. 
Second, entrepreneurs claim that communicating their social-good narrative during a pitch can also help to differentiate the venture from businesses in the space that do not communicate such a narrative. Gamma's CEO explains that in pitches he tries to convey the "[business] fundamentals" but that the social narrative is "clearly a differentiator" from other firms in the space. The social enterprise's CSO explains that, in fact, the reason why the label "social venture" is used when pitching the company is because "it's sort of tough to describe what we do in a way that differentiates us from other startups." In particular, although their business model is unique, it is easy to categorize the company as belonging to the crowded "daily-deals" space, which includes companies like Groupon. He explains, "we're not a daily-deal site, but [Gamma] is essentially getting deals from restaurants. So to create differentiation, to create awareness of what we are doing, the hunger piece is crucial." The CEO is very conscious of the need to differentiate the company from other firms and to make clear that it is a social enterprise. Leveraging the company's social-good narrative, in conjunction with their compelling business narrative, allows him to create this differentiation.

Third, and finally, entrepreneurs' statements suggest another function of communicating the social-good narrative to investors: creating opportunities for investors to realize that there is overlap between their personal beliefs and values and the enterprise's social-good mission. In this way, the social-good narrative provides investors with something they can identify with beyond the business-related characteristics of the venture. For instance, the $\mathrm{CEO}$ of Beta questions the extent that a traditional investor will "risk their livelihood or their resources" by completely investing based on their values. 
However, he explains that their social-good message probably "appeals to investors" values."

I think our investors share our values for the most part. We've got an interesting group. There's a group of guys that are originally from East Asia that have strong values towards helping their country. I have a couple of investors that are Christian, and what we do coincides with their belief system.

Moreover, the CEO believes that their social-good message has caused investors' families

to identify with the venture, more so than with other investments.

The greatest interest in the social side has been from investors' family members. So almost every one of my investors said that their family is more interested in this investment than anything else that they do. Their family is always asking them questions. What's up with Beta? When can I get the parents from our kids' classroom to maybe try it? When can we get it into our church? When can we do this? They've become kind of behind us - even though we haven't met a lot of them - they've become very much behind the scenes proponents of us because I guess it's a story they like to tell. It's much nicer to tell their peers about the family's investment in this than it is an assisted living home or a steel company.

These statements suggest that social-good narratives provide investors with

another way to connect with the activities of the venture and, perhaps, gives them a story that they can tell and gain utility from participating in.

\section{Are Investors Influenced by Social-Good Narratives?}

It is clear that entrepreneurs believe that investors can be influenced by socialgood narratives - even if the influence is little more than the "cherry on top" of a compelling, business-focused pitch. However, are investors, in fact, swayed by such practices?

Most investors claim that non-business narratives had no influence on their decision to invest in the successful social enterprises. One of Gamma's investor's, for instance, describes the limited role played by the social-good message in his angel group. He viewed 
[the social message] as a marketing technique. That deal was done based on does Gamma have something that will take off, and all the restaurants in America will see its merit, and there will be wealth built. I don't think anybody in our group invested in it so that money will be given to a food bank [i.e. the social-good component of the business].

Such statements, of course, are not evidence that investors were unaffected by the non-business narratives. For instance, the social-good and personal narratives might operate at a level at which the investors are not conscious (e.g. they may influence attention processes governed by automatic processes; Wentura, Rothermund, Bak, 2000). Or, investors may simply deny being influenced by such narratives because they believe they will lose credibility within their investment community if they admit to considering anything beyond the "business facts" of an investment (a claim by one of alpha's investors seems to support this possibility $)^{16}$.

There were some investors, however, that admitted to being influenced by nonbusiness narratives. For instance, one of Alpha's investors states that, while he does not think that the social-good message was hugely influential with other members of the angel group, he himself was influenced by the CEO's social message.

I've never admitted this before, and in this [angel] community it's really is an odd thing to say, but I do get fulfillment out investing in, in putting my money to work in something that provides more than just a financial return. I've seen it work so well over the last 25 years at Nature's Foods that I'm convinced that business, corporations actually, are the most enabled to solve any of the world's problems. A responsibly run organization, using a portion of its profits for social good - I know that for some people that probably sounds like communism - but to me that is the future and I think the world will be a much better place as a result of it.

\footnotetext{
${ }^{16}$ A third possibility is that the social-good narratives influence investors, but they do so because they are interpreted through a business lens. For instance, an investor may appreciate a compelling social narrative not because he or she is influenced by the social problem, but because, as suggested, it is believed that the social narrative will be an effective marketing tool or that it will be particularly effective with customers.
} 
He goes on to describe the mind-set of the investor-type that is most likely to be influenced by a social-good narrative.

So unless you are going into it with an understanding that you are becoming part of something larger, I like to think it is an enhancing aspect of community. So I think the solution that Alpha provides really enhances people's lives. And so the investor must be doing it with a broader mindset, that "yes, it's an investment, I need a return on it and there's a less tangible aspect. I can have an impact through this investment. I can do something good.

Interestingly, Alpha's CEO recognizes that her venture possesses multiple types of investors. In fact, she describes them as belonging to "three categories". She states, “they're either straight on tech - you know, they like early-stage technology, consumer tech; [or] they believe in the viability of the mom market online - so, that would be the second category; or [they are] a social investor." This suggests that entrepreneurs must link (and tailor) their narratives in a way that not only appeals to different audience groups (e.g. investors vs. customers vs. the media) but also in ways that appeal to subgroups of audiences (e.g. tech investors vs. traditional investors vs. impact investors).

\section{Linking Business and Personal Narratives}

Although entrepreneurs emphasize linking their business and social-good narratives, investors make statements suggesting that it is also influential to combine founders' personal narratives with their business narratives. As discussed previously, personal narratives can be linked to business narratives to introduce information about prior work and life experiences that are relevant to the business. This can help an entrepreneur to engender credibility and inspire confidence with investors. For instance, the lead investor of Beta describes being influenced by the founder's personal story, 
which is based on a unique collection of work experiences that culminated in the founding of the venture.

I believed in [the Founder] and thought that, one, his story was compelling and, two, he really had done a lot of work on this, that it was worth putting some money into it, feeding it and beginning to really develop out the business model to where it is today.

Linking personal and business narratives can also reinforce entrepreneurs' passion for the business. The director of an incubator that evaluated Lambda's pitch explained that it conveyed the founder's passion.

There's a personal narrative behind it [the business message], what makes it even stronger it conveys passion and all the other intangibles that people invest in.

Although he explains that the founder's passion was an important criterion in accepting the venture into the incubator, he also reiterates, "you can't get there on passion alone." A second evaluator at the incubator, who is also an angel investor, found four elements attractive in Lambda's pitch.

What I saw was a strong personal story - [the founder's] story and his family member's health issue - an intense market pain, [the founder's] personal domain expertise, and market size. For me those four things are key.

Thus the venture was perceived as attractive because the founder's pitch communicated both personal (e.g. the founder's story, work experience) and business factors (e.g. the pain point, market size). Indeed, the former director of the incubator explains why he advised the company's CEO not to drop the "social good / personal angle" from his pitch.

It's an intricate part of the story. It's what gets your attention and gives [the CEO] some credibility with certain groups. I mean, he's going to get their attention with the strong personal story, but then he's going to really get their attention when he says, 'we can reduce the cost of your application process by $90 \%$ 
The investor's statement suggests that, in additional to capturing attention, another important function of social-good and personal narratives is to provide information that creates credibility with certain stakeholder groups. For instance in this case, the CEO's personal story demonstrates that he has first-hand experience with the social problem the venture is addressing (i.e. inefficiencies in the delivery of social services). These experiences are particularly valuable in establishing credibility with one of his primary customer groups, social workers. The statement also reinforces that, at least in this investor's eyes, what really captures the customer's attention is the venture's business solution (i.e. that it will "reduce the cost of [the] application process by $90 \%$ ). However, the previous statements are evidence that the pitch's persuasiveness is not solely attributable to the business narrative.

Finally, as Gamma's CSO succinctly asserts, "investors are in the business of making money." Thus, they are primarily interested in ventures' business narratives. However, based both on what investors claim is important and on the communication of companies they choose to invest in, linking a dominant business narrative with elements of both social-good and personal narratives creates compelling communication that can influence investors' decisions.

\section{Summary}

In this chapter I provided evidence of the different combinations (or "linkings") of social enterprise narratives. I illustrated the types of information conveyed in these linked narratives and explained why entrepreneurs may engage in this tactic. Moreover, I 
presented evidence of how entrepreneurs conceive of such narratives and how one group of resource providers, investors, receives them.

In communication with investors, successful entrepreneurs use a dominate business narrative that is linked with components of their social-good and personal narratives. Specifically, with investors, combinations of business and personal narratives can introduce information about prior work and life experiences that are relevant to the business, which can help an entrepreneur to engender credibility and inspire confidence with investors and other stakeholder groups (e.g. beneficiaries). It can also reinforce entrepreneurs' passion for the business. In contrast, linking business and social-good narratives can help to grab investors' attention, to differentiate the venture from businesses not possessing a social-good component, and to create opportunities for investors to realize that there is overlap between their personal beliefs and values and the venture's social mission. Figure 2 provides a graphical depiction of narrative linking. 


\section{FIGURE 2:}

\section{NARRATIVE LINKING}

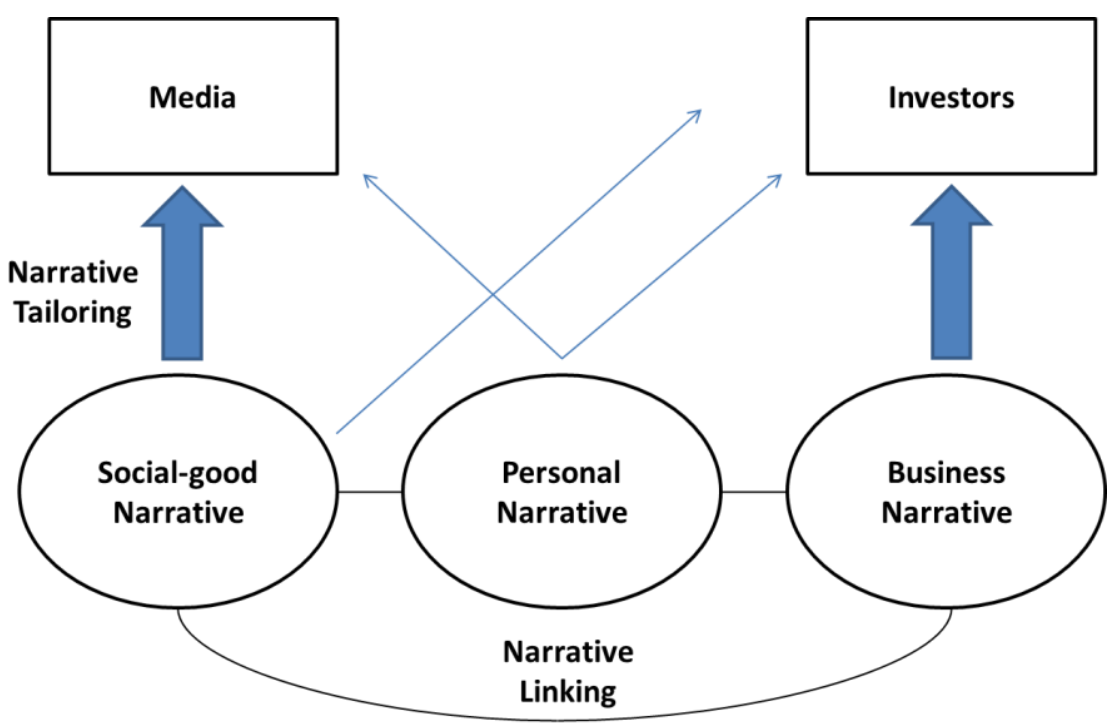

Overall, successful social enterprises did not tell business, social-good, or personal narratives in isolation. Instead, they craft complex communication that links a primary narrative-type with elements of the other narrative-types. In the next chapter, I describe a third factor - narrative multiplexity - that differentiated successful from unsuccessful social enterprise narratives. 


\section{CHAPTER 8:}

\section{HOW DO SOCIAL ENTREPRENEURS USE NARRATIVES TO ACQUIRE RESOURCES?}

\section{Narrative Multiplexity}

In the previous two chapters, evidence was presented that the successful social entrepreneurs engaged in two narrative tactics: tailoring and linking. As described, tailoring involves emphasizing different narrative-types (i.e. business, social-good, or personal) depending on the target audience. Linking, in contrast, involves combining narrative-types to make communication more compelling. There is evidence, however, that the narratives of the successful social enterprises possessed an additional characteristic: multiplexity.

In general, multiplex narratives contain multiple, potential ties to more than one audience. In the context of social enterprises, such narratives have multiple, potential ties to more than one customer and beneficiary group. As will be described, multiplexity influences the persuasiveness of narratives by providing more points of connection, or "touch-points", so that a greater number of audiences can identify and interact with the narrative. In contrast, the narratives of unsuccessful enterprises contained less potential ties and, thus, were less likely to influence multiple customer and beneficiary groups.

Multiplexity can be understood by examining how it is used in all three narrativetypes - personal, social-good, and business. Tables 10-12 provide examples for each type 
of narrative. As the tables demonstrate, all of the successful ventures constructed narratives with this characteristic.

TABLE 10:

PERSONAL NARRATIVE MULTIPLEXITY

\begin{tabular}{|c|c|c|c|c|}
\hline COMPANY & $\begin{array}{c}\text { TIES TO } \\
\text { PRIMARY } \\
\text { BENEFICIARIES }\end{array}$ & $\begin{array}{c}\text { TIES TO } \\
\text { SECONDARY } \\
\text { BENEFICIARIES }\end{array}$ & $\begin{array}{c}\text { TIES TO } \\
\text { PRIMARY } \\
\text { CUSTOMERS }\end{array}$ & $\begin{array}{c}\text { TIES TO } \\
\text { SECONDARY } \\
\text { CUSTOMERS }\end{array}$ \\
\hline $\begin{array}{c}\text { FUNDED } \\
\text { VENTURES } \\
\text { Alpha }\end{array}$ & $\begin{array}{l}\text { Founder creates } \\
\text { connection to the } \\
\text { group most } \\
\text { influenced by the } \\
\text { social enterprise } \\
\text { (working moms). } \\
\text { "So I was a school } \\
\text { volunteer and a } \\
\text { working mom and I } \\
\text { kept noticing that my } \\
\text { Blackberry was } \\
\text { filling up with reply } \\
\text { all e-mail request } \\
\text { over whose turn it } \\
\text { was to help at table } \\
\text { time or help at } \\
\text { recess. And the more } \\
\text { I talked to working } \\
\text { moms, we were all } \\
\text { overwhelmed with } \\
\text { the communication } \\
\text { about volunteering." } \\
\text { (Founder/CEO) }\end{array}$ & $\begin{array}{l}\text { Founder's } \\
\text { connection to other } \\
\text { groups influenced by } \\
\text { the enterprise's } \\
\text { social mission (other } \\
\text { volunteer } \\
\text { organizations). } \\
\text { "Leadership positions } \\
\text { in PTA and Scouts. } \\
\text { Anyone who has } \\
\text { volunteered knows } \\
\text { about the difficulties } \\
\text { in organizing groups } \\
\text { of people - the } \\
\text { frustrating process of } \\
\text { back-and-forth e- } \\
\text { mails, phone calls } \\
\text { and sign-up sheets. } \\
\text { Good people } \\
\text { sometimes drop out } \\
\text { because it's a hassle." } \\
\text { (Founder/CEO) }\end{array}$ & $\begin{array}{l}\text { Founder's } \\
\text { connection to the } \\
\text { dominant } \\
\text { customer group } \\
\text { (corporations). } \\
\text { "Before starting } \\
\text { Alpha, I was a } \\
\text { consultant } \\
\text { helping } \\
\text { organizations } \\
\text { improve } \\
\text { leadership } \\
\text { practices and } \\
\text { business } \\
\text { processes. } \\
\text { Essentially, I'm } \\
\text { an expert in } \\
\text { helping } \\
\text { organizations } \\
\text { improve their } \\
\text { performance and } \\
\text { better meet } \\
\text { customer needs." } \\
\text { (Founder/CEO) }\end{array}$ & $\begin{array}{l}\begin{array}{l}\text { Founder's } \\
\text { connection to } \\
\text { other customer } \\
\text { groups } \\
\text { (nonprofits) }\end{array} \\
\text { "For a long time, } \\
\text { I had regularly } \\
\text { volunteered at } \\
\text { events like } \\
\text { serving } \\
\text { Thanksgiving } \\
\text { dinner for the } \\
\text { homeless, park } \\
\text { cleanups, etc. } \\
\text { When Hurricane } \\
\text { Katrina sent } \\
\text { thousands of } \\
\text { evacuees to my } \\
\text { home town, I saw } \\
\text { for the first time } \\
\text { how difficult and } \\
\text { time-consuming } \\
\text { it was to organize } \\
\text { and coordinate } \\
\text { volunteers. } \\
\text { (Founder/CEO) }\end{array}$ \\
\hline
\end{tabular}


TABLE 10 (cont.)

\begin{tabular}{|c|c|c|c|c|}
\hline Beta & $\begin{array}{l}\text { Founder creates } \\
\text { connection to the } \\
\text { group most } \\
\text { influenced by the } \\
\text { social enterprise } \\
\text { (nonprofits). } \\
\text { "More than a decade } \\
\text { of work in the } \\
\text { nonprofit sector } \\
\text { made it evident to me } \\
\text { the } \\
\text { divide between } \\
\text { charitable causes and } \\
\text { the power of } \\
\text { business community } \\
\text { was } \\
\text { massive, and the } \\
\text { programs to close the } \\
\text { gap didn't exist." } \\
\text { (Founder/CEO) }\end{array}$ & $\begin{array}{l}\text { Founder's } \\
\text { connection to other } \\
\text { groups influenced by } \\
\text { the enterprise's } \\
\text { social mission (small } \\
\text { businesses). } \\
\text { "Going back to my } \\
\text { local development } \\
\text { roots, we're } \\
\text { providing the same } \\
\text { technologies to } \\
\text { existing coalitions. } \\
\text { We work with } \\
\text { Chambers of } \\
\text { Commerce, business } \\
\text { associations, and } \\
\text { local governments } \\
\text { across the world to } \\
\text { provide tools to } \\
\text { incentivize local } \\
\text { purchase behavior. } \\
\text { It's what we call, a } \\
\text { "community-based } \\
\text { loyalty program. You } \\
\text { shop at a local } \\
\text { merchant that gives } \\
\text { you currency to } \\
\text { support local causes." } \\
\text { (Founder/CEO) }\end{array}$ & $\begin{array}{l}\text { Founder's } \\
\text { connection to the } \\
\text { dominant } \\
\text { customer group } \\
\text { (large consumer } \\
\text { brands). } \\
\text { "So this became } \\
\text { a passion of } \\
\text { mine. I wanted to } \\
\text { dig in deeper to } \\
\text { really understand } \\
\text { how can we } \\
\text { incentivize } \\
\text { brands to support } \\
\text { civil society, to } \\
\text { support } \\
\text { nonprofits } \\
\text { and charities. It's } \\
\text { one thing for a } \\
\text { brand to give } \\
\text { money to a } \\
\text { cause; it's } \\
\text { another thing for } \\
\text { them to be able to } \\
\text { measure the } \\
\text { efficacy of that } \\
\text { giving, measure } \\
\text { the } \\
\text { success, and } \\
\text { some cases even } \\
\text { the return on } \\
\text { investment." } \\
\text { (Founder/CEO) }\end{array}$ & No evidence \\
\hline
\end{tabular}


TABLE 10 (cont.)

\begin{tabular}{|c|c|c|c|c|}
\hline Epsilon & $\begin{array}{l}\text { Founder creates } \\
\text { connection to the } \\
\text { group most } \\
\text { influenced by the } \\
\text { social enterprise } \\
\text { (cash-strapped } \\
\text { nonprofits). } \\
\text { "The incubator-like } \\
\text { machines delivered } \\
\text { from the March of } \\
\text { Dimes saved my } \\
\text { daughter's life when } \\
\text { she was born } \\
\text { prematurely. Then I } \\
\text { had a set of twin girls } \\
\text { born two years later, } \\
\text { six weeks premature } \\
\text { again, and they were } \\
\text { put in the same } \\
\text { machines. Now they } \\
\text { are all fine and } \\
\text { healthy. Through this } \\
\text { experience I realized } \\
\text { money can do a lot } \\
\text { of great things [...] } \\
\text { but I started to } \\
\text { wonder how I can } \\
\text { leverage technology } \\
\text { to help non-profits } \\
\text { realize a greater } \\
\text { impact?" (Co- } \\
\text { founder/CEO2) }\end{array}$ & No evidence & $\begin{array}{l}\text { Founder's } \\
\text { connection to } \\
\text { dominant } \\
\text { customer group } \\
\text { (corporations). } \\
\text { "I spent about six } \\
\text { years with IBM, } \\
\text { working on } \\
\text { analyzing threats } \\
\text { to the Internet at } \\
\text { large. There I did } \\
\text { a ton of very } \\
\text { high-level stuff. I } \\
\text { founded a } \\
\text { security } \\
\text { intelligence } \\
\text { group and did } \\
\text { some really cool } \\
\text { things. Then I } \\
\text { spent a year } \\
\text { doing research } \\
\text { for the } \\
\text { Department of } \\
\text { Defense on } \\
\text { computer } \\
\text { security issues." } \\
\text { (Co- } \\
\text { founder/CEO1) }\end{array}$ & No evidence \\
\hline
\end{tabular}


TABLE 10 (cont.)

\begin{tabular}{|c|c|c|c|c|}
\hline Gamma & $\begin{array}{l}\text { Founder creates } \\
\text { connection to the } \\
\text { group most } \\
\text { influenced by the } \\
\text { social enterprise } \\
\text { ("the hungry). } \\
\text { When we think about } \\
\text { hunger, including } \\
\text { me, we live in a } \\
\text { bubble. So in } \\
\text { December I started } \\
\text { volunteering at a } \\
\text { place called Alliance } \\
\text { Food Pantry." } \\
\text { (Founder/CEO) } \\
\\
\text { "[Founder] started } \\
\text { Gamma in 2011 after } \\
\text { volunteering at a } \\
\text { food pantry with his } \\
\text { 17-year-old son. He } \\
\text { felt that the issue of } \\
\text { hunger was being } \\
\text { overlooked across } \\
\text { the country." } \\
\text { (corporate } \\
\text { communication) }\end{array}$ & No evidence & $\begin{array}{l}\text { Founder's } \\
\text { connection to } \\
\text { dominant } \\
\text { customer group } \\
\text { (restaurant } \\
\text { owners). } \\
\text { "[The founder] } \\
\text { noticed there } \\
\text { were times when } \\
\text { restaurants had } \\
\text { empty tables, and } \\
\text { he thought about } \\
\text { a service to fill } \\
\text { the most } \\
\text { expensive table: } \\
\text { the empty one." } \\
\text { (CSO) }\end{array}$ & $\begin{array}{l}\text { Founder's } \\
\text { connection to } \\
\text { other customer } \\
\text { groups } \\
\text { (individual } \\
\text { consumers). } \\
\text { “The problem } \\
\text { was, I was } \\
\text { playing piano } \\
\text { bars to put } \\
\text { myself through } \\
\text { college, and } \\
\text { when you play } \\
\text { piano bars - and } \\
\text { you are much } \\
\text { slimmer and } \\
\text { better looking - } \\
\text { (laughs) you pick } \\
\text { up the girls. And } \\
\text { girls wanted to } \\
\text { go out and I } \\
\text { needed some } \\
\text { money to take } \\
\text { them out. But I } \\
\text { didn't have } \\
\text { enough money." } \\
\text { (Founder/CEO) }\end{array}$ \\
\hline
\end{tabular}


TABLE 10 (cont.)

\begin{tabular}{|c|c|c|c|c|}
\hline Lambda & $\begin{array}{l}\text { Founder creates } \\
\text { connection to the } \\
\text { group most } \\
\text { influenced by the } \\
\text { social enterprise } \\
\text { (individuals in need } \\
\text { of social services). } \\
\text { "I went off to } \\
\text { college, and when I } \\
\text { was } 26 \text { I got a phone } \\
\text { call and I was faced } \\
\text { with the most } \\
\text { difficult decision I } \\
\text { ever had to make. I } \\
\text { flew to New York, } \\
\text { packed [my mom's] } \\
\text { things, brought her to } \\
\text { Texas, and became } \\
\text { her legal guardian. I } \\
\text { had no idea what I } \\
\text { was getting into. I } \\
\text { was scared. I was } \\
\text { barely figuring out } \\
\text { who I was. What did } \\
\text { I know about taking } \\
\text { care of the person } \\
\text { that raised me? And } \\
\text { through that process } \\
\text { I learned that the way } \\
\text { social services are } \\
\text { delivered in this } \\
\text { country is broken. } \\
\text { And because of this } \\
\text { experience I found } \\
\text { my calling." } \\
\text { (Founder/CEO) }\end{array}$ & No evidence & $\begin{array}{l}\text { Founder's } \\
\text { connection to } \\
\text { dominant } \\
\text { customer group } \\
\text { (social service } \\
\text { organizations). } \\
\text { "I enjoyed public } \\
\text { policy so I spent } \\
\text { four years as a } \\
\text { consultant to the } \\
\text { state of Texas. } \\
\text { [...] my job } \\
\text { really was to look } \\
\text { at how can the } \\
\text { state of Texas } \\
\text { administer their } \\
\text { government } \\
\text { programs with } \\
\text { less expense and } \\
\text { more efficiency } \\
\text { for the clients." } \\
\text { (Founder/CEO) } \\
\text { "So where we } \\
\text { make money is } \\
\text { on the application } \\
\text { processing side, } \\
\text { and that's the } \\
\text { world that I came } \\
\text { from." } \\
\text { (Founder/CEO) }\end{array}$ & $\begin{array}{l}\text { Founder's } \\
\text { connection to } \\
\text { other customer } \\
\text { groups (social } \\
\text { workers). } \\
\text { "And our team } \\
\text { are made up of } \\
\text { four hardworking } \\
\text { people that have } \\
\text { actually been } \\
\text { there themselves } \\
\text { and have } \\
\text { dedicated their } \\
\text { careers to this } \\
\text { industry. Fifty } \\
\text { percent of our } \\
\text { team are social } \\
\text { workers." } \\
\text { (Founder/CEO) }\end{array}$ \\
\hline
\end{tabular}


TABLE 10 (cont.)

\begin{tabular}{|c|c|c|c|c|}
\hline $\begin{array}{c}\text { UNFUNDED } \\
\text { VENTURES } \\
\text { Rho }\end{array}$ & $\begin{array}{l}\text { Founder creates } \\
\text { connection to the } \\
\text { group most } \\
\text { influenced by the } \\
\text { social enterprise } \\
\text { (small to moderate } \\
\text { sized nonprofits). } \\
\text { "I moved from there } \\
\text { to do consulting for } \\
\text { the government, as } \\
\text { well as for non- } \\
\text { profits. And one of } \\
\text { the things that I } \\
\text { loved the most was } \\
\text { to help non-profits } \\
\text { scale their impact. } \\
\text { So, I decided to start } \\
\text { the a few years ago } \\
\text { and the sole goal of } \\
\text { Rho was to help non- } \\
\text { profits raise funding } \\
\text { for whatever } \\
\text { programs, whatever } \\
\text { projects, whatever } \\
\text { mission that they } \\
\text { had." (Co-founder / } \\
\text { CEO) }\end{array}$ & $\begin{array}{l}\text { No multiplexity: form } \\
\text { ties to a single, } \\
\text { narrowly defined } \\
\text { beneficiary group }\end{array}$ & $\begin{array}{l}\text { "We've been } \\
\text { dabbling with } \\
\text { fundraising } \\
\text { technology since } \\
\text { 2007, and our trip } \\
\text { to Uganda, a few } \\
\text { years ago, was } \\
\text { the catalyst for } \\
\text { Rho. We served } \\
\text { Action for } \\
\text { Children (AFC), } \\
\text { a Kampala-based } \\
\text { NGO that serves } \\
\text { children and } \\
\text { families } \\
\text { vulnerable due to } \\
\text { HIV/AIDS and } \\
\text { poverty, by } \\
\text { providing pro } \\
\text { bono marketing } \\
\text { and IT support." } \\
\text { (Co- } \\
\text { founder/CEO) }\end{array}$ & $\begin{array}{l}\text { No multiplexity: } \\
\text { form ties to a } \\
\text { single, narrowly- } \\
\text { defined customer } \\
\text { group }\end{array}$ \\
\hline Sigma & $\begin{array}{l}\text { Founder creates } \\
\text { connection to the } \\
\text { group most } \\
\text { influenced by the } \\
\text { social enterprise } \\
\text { (nonprofits). } \\
\text { "After working with } \\
\text { nonprofits for so } \\
\text { long, the main reason } \\
\text { for creating this was } \\
\text { not to create cash } \\
\text { flow. The main } \\
\text { reason to create this } \\
\text { was to create revenue } \\
\text { for nonprofits." } \\
\text { (Founder/CEO) }\end{array}$ & $\begin{array}{l}\text { No multiplexity; } \\
\text { personal narrative } \\
\text { does not include ties } \\
\text { to secondary } \\
\text { beneficiary groups. }\end{array}$ & $\begin{array}{l}\text { No multiplexity; } \\
\text { personal } \\
\text { narrative does not } \\
\text { include ties to } \\
\text { customer groups. }\end{array}$ & $\begin{array}{l}\text { No multiplexity; } \\
\text { personal } \\
\text { narrative does not } \\
\text { include ties to } \\
\text { secondary } \\
\text { customer groups. }\end{array}$ \\
\hline Omega & $\begin{array}{l}\text { No multiplexity; } \\
\text { Lack of personal nar. }\end{array}$ & $\begin{array}{l}\text { No multiplexity; } \\
\text { Lack of personal nar. }\end{array}$ & $\begin{array}{l}\text { No multiplexity; } \\
\text { Lack of personal }\end{array}$ & $\begin{array}{l}\text { No multiplexity; } \\
\text { Lack of personal }\end{array}$ \\
\hline
\end{tabular}




\section{Multiplexity in Personal Narratives}

Successful social enterprises tailored their communication to emphasize personal narratives with media audiences. Moreover, they link their personal narratives with (dominant) business narratives when communicating with investors. In addition to these practices, the successful entrepreneurs also created multiplex narratives that described the focal character of their personal narratives - themselves - in multiple ways. By doing so, they created opportunities for multiple customer and beneficiary groups to connect to the narrative (and to the entrepreneur).

The communication of Alpha's founder and CEO provides examples of the multiplex potential ties between the entrepreneur and the enterprise's stakeholder groups. For instance, one framing links the founder to the venture's primary beneficiary group: affluent, working moms.

So I was a school volunteer and a working mom and I kept noticing that my Blackberry was filling up with reply all e-mail request over whose turn it was to help at table time or help at recess. And the more I talked to working moms, we were all overwhelmed with the communication about volunteering.

This statement places the CEO in the venture's primary beneficiary group. It also conveys that the CEO has first-hand knowledge of the problems of this group (i.e. "we were all overwhelmed...”).

In other instances, the CEO describes the experiences that led her to found the venture more broadly. For instance, she attributes her motivation for founding Alpha to her: 
back-and-forth e-mails, phone calls and sign-up sheets. Good people sometimes drop out because it's a hassle.

This communication portrays the personal experiences of the CEO as connecting her to a much larger group than just "working moms" (i.e. to "anyone who has volunteered"). As described below, this corresponds to Alpha's attempts to generate interest in their product in groups outside of their primary customer group.

Finally, in other communications the CEO describes her connection to the venture's primary and secondary customer groups: businesses and nonprofits. She highlights a connection to the business community by explaining:

Before starting Alpha, I was a consultant helping organizations improve leadership practices and business processes. Essentially, I'm an expert in helping organizations improve their performance and better meet customer needs.

Second, the CEO suggests a connection to the nonprofit community. In particular, she describes watching the plight of local nonprofits following Hurricane Katrina.

For a long time, I had regularly volunteered at events like serving Thanksgiving dinner for the homeless, park cleanups, etc. When Hurricane Katrina sent thousands of evacuees to my home town, I saw for the first time how difficult and time-consuming it was to organize and coordinate volunteers. Many people were moved to help, but I kept seeing the same pattern - a few people did most of the heavy lifting, and they quickly burned out from trying to coordinate too many small administrative tasks in addition to their other responsibilities.

This statement appeals to small and medium-sized nonprofits for a reason. These organizations often do not have the resources to pay for expensive volunteer-management software. So the Alpha's solution is particularly appealing to such organizations.

By describing herself in multiple ways, none of which are contradictory, the CEO provides multiple opportunities for audiences to identify with her experiences. Moreover, there is evidence that the CEO's multiple portrayals are associated with the company receiving attention from a diverse collection of media sources. For instance, they have 
been featured in media outlets focusing on parenting, volunteering, business and online technology, and non-profit consulting. Each of these corresponds to one of the ways that the CEO frames who she is as an entrepreneur.

\section{Multiplexity in Social-Good Narratives}

In the same way that social enterprises can attempt to create multiplex ties between their personal narratives and stakeholder groups, they can also construct "dense" social-good narratives that contain many potential ties to beneficiary groups. These narratives are contrasted with narratives that frame the venture's social mission as narrowly applying to one beneficiary (e.g. refugees) and are not flexible enough to appeal to numerous groups. Table 11 provides evidence and illustrative examples.

TABLE 11:

SOCIAL-GOOD NARRATIVE MULTIPLEXITY

\begin{tabular}{|c|c|c|}
\hline COMPANY & $\begin{array}{l}\text { TIES TO PRIMARY } \\
\text { BENEFICIARIES }\end{array}$ & $\begin{array}{c}\text { TIES TO SECONDARY } \\
\text { BENEFICIARIES }\end{array}$ \\
\hline $\begin{array}{c}\text { FUNDED } \\
\text { VENTURES } \\
\text { Alpha }\end{array}$ & $\begin{array}{l}\text { "Teachers rely on parents as their go- } \\
\text { to resource for support. More than } \\
\text { ever, there is a pressing need for } \\
\text { classroom help and fundraising, } \\
\text { making the parent volunteer a hot } \\
\text { commodity. By making it easier and } \\
\text { more efficient for busy parents to } \\
\text { actively volunteer at school, we } \\
\text { expect Alpha to become the go-to } \\
\text { tool this back-to-school season." } \\
\text { (Founder/CEO) }\end{array}$ & $\begin{array}{l}\text { "We support }[\ldots] \text { work place } \\
\text { volunteering, and faith-based } \\
\text { volunteering, people volunteering in } \\
\text { their churches and congregations. For } \\
\text { large non-profits, like the Red Cross, } \\
\text { for example, they have local disaster } \\
\text { action teams, and those are volunteer } \\
\text { teams. They don't have access to the } \\
\text { large proprietary volunteer } \\
\text { management software. So they use us } \\
\text { to coordinate their groups. We save } \\
\text { them one to two man days a month in } \\
\text { volunteer coordination time." } \\
\text { (Founder/CEO) }\end{array}$ \\
\hline
\end{tabular}




\section{TABLE 11 (cont.)}

\begin{tabular}{|c|c|c|}
\hline Beta & $\begin{array}{l}\text { "By offering consumers an easy way } \\
\text { to support the causes important to } \\
\text { them, charities around the world will } \\
\text { gain new revenue streams." } \\
\text { (Founder/CEO) }\end{array}$ & $\begin{array}{l}\text { "One of our statements is we allow } \\
\text { the consumers to support the causes } \\
\text { they care about without ever dipping } \\
\text { into their pockets, i.e., you don't need } \\
\text { expendable income to be a } \\
\text { philanthropist." (Founder/CEO) }\end{array}$ \\
\hline Epsilon & $\begin{array}{l}\text { We serve any entity which is a } \\
501 C 3, \mathrm{C} 7, \mathrm{C} 12 \ldots \text { literally all 'the } \\
\text { C's'... IRS certified non-profits or not- } \\
\text { for-profits [...] Epsilon now has more } \\
\text { than } 2 \text { million charities in our } \\
\text { database which our donors can } \\
\text { support so chances are, we have your } \\
\text { charity." }\end{array}$ & $\begin{array}{l}\text { "Americans are famed for giving and } \\
\text { we're just trying to make it easy and } \\
\text { fun for them to give to their } \\
\text { favorite charities." (Founder/CEO) }\end{array}$ \\
\hline Gamma & $\begin{array}{l}\text { "One in six Americans go to bed } \\
\text { hungry each night, so we have } \\
\text { created a model that when you eat at } \\
\text { one of our participating restaurants, } \\
\text { we feed a person through one of our } \\
\text { local food pantries. When you eat, } \\
\text { they eat." (Founder/CEO) }\end{array}$ & $\begin{array}{l}\text { Has not developed ties to a secondary } \\
\text { beneficiary group. }\end{array}$ \\
\hline Lambda & $\begin{array}{l}\text { "Epsilon focuses on connecting the } \\
\text { underprivileged with need-based } \\
\text { services, making it easy for people to } \\
\text { find food, health, housing and } \\
\text { education programs in just a few } \\
\text { clicks. Epsilon's mission is to make } \\
\text { human service program information } \\
\text { more accessible to both people and } \\
\text { programs." (Founder/CEO) }\end{array}$ & $\begin{array}{l}\text { "Ever had someone in your family } \\
\text { find out they had cancer? A car } \\
\text { accident? Or is unemployed for a } \\
\text { long time? Have you ever helped this } \\
\text { person fill out a Medicaid form } \\
\text { (Government Health Insurance) or } \\
\text { apply for Social Security Disability } \\
\text { payments? Have you ever driven } \\
\text { across town to go to a government } \\
\text { office only to find out you didn't have } \\
\text { the right paperwork?" (Founder/CEO) }\end{array}$ \\
\hline $\begin{array}{c}\text { UNFUNDED } \\
\text { VENTURES } \\
\text { Rho }\end{array}$ & $\begin{array}{l}\text { "Rho is a startup based in NYC. Our } \\
\text { experience in the non-profit sector } \\
\text { inspired us to create a company that } \\
\text { serves the needs of a greatly } \\
\text { underserved group -- small to } \\
\text { medium sized non-profits." (Co- } \\
\text { founder/CEO) }\end{array}$ & $\begin{array}{l}\text { Has not developed ties to a secondary } \\
\text { beneficiary group. }\end{array}$ \\
\hline
\end{tabular}




\section{TABLE 11 (cont.)}

\begin{tabular}{|c|c|c|}
\hline Sigma & $\begin{array}{l}\text { "The main reason to create this was } \\
\text { to create revenue for nonprofits. If } \\
\text { not creating for nonprofits, it doesn't } \\
\text { make sense to be around. Nonprofits } \\
\text { are a key part. Actually, they are the } \\
\text { key part of the model. If we take the } \\
\text { nonprofit piece out of this, there is no } \\
\text { business." (Founder/CEO) }\end{array}$ & $\begin{array}{l}\text { Has not developed ties to a secondary } \\
\text { beneficiary group. }\end{array}$ \\
\hline Omega & $\begin{array}{l}\text { "For nonprofits and causes, it's a } \\
\text { great way to build fundraising, } \\
\text { awareness, and advocacy from online } \\
\text { communities." (Co-founder/CEO2) }\end{array}$ & $\begin{array}{l}\text { Has not developed ties to a secondary } \\
\text { beneficiary group. }\end{array}$ \\
\hline
\end{tabular}

Alpha's communication can be used as an example. In describing the social-good created by its product, the $\mathrm{CEO}$ uses a social narrative that focuses on its primary beneficiary, parent volunteers.

Teachers rely on parents as their go-to resource for support. More than ever, there is a pressing need for classroom help and fundraising, making the parent volunteer a hot commodity. By making it easier and more efficient for busy parents to actively volunteer at school, we expect Alpha to become the go-to tool this back-to-school season.

At schools, parents are called on to bridge critical funding gaps - helping in the classroom, supervising in the cafeteria and library, and supporting fundraisers like carnivals and concessions stands. Alpha gives parents and teachers a simple way to coordinate help that's familiar to them, similar to launching an online party invitation.

In these quotations the CEO communicates that she understands the problems faced by the venture's primary beneficiaries and that her product is a perfect solution.

In other communication the CEO focuses on the social problems of other groups that can benefit from the product. In doing so, she creates several, secondary beneficiary groups.

We support $[\ldots]$ work place volunteering, and faith-based volunteering, people volunteering in their churches and congregations. For large non-profits, like the Red 
Cross, for example, they have local disaster action teams, and those are volunteer teams. They don't have access to the large proprietary volunteer management software. So they use us to coordinate their groups. We save them one to two man days a month in volunteer coordination time.

Finally, in still other communication, the CEO emphasizes the broadest possible group of beneficiaries that can be influenced by the venture: volunteers of any type.

Any person organizing a group of volunteers can do it much simpler with Alpha. We're sort of like an e-vite party invitation on steroids for group volunteering.

Communication with this degree of flexibility allows a wide array of beneficiaries to form connections to the organization. This is important for a social venture because, as discussed, each of these beneficiary groups stands to receive the social-good created by the venture. Thus, each beneficiary group can represent a unique collection of supporters. As supporters, these groups may be willing to impart resources, such as donations, volunteer hours, and word-of-mouth endorsements of the social enterprise.

\section{Multiplexity in Business Narratives}

Lastly, business narratives are targeted at two groups of stakeholders, a social enterprise's investors and customers. The latter group, however, constitutes the main "characters" of such narratives. The successful social entrepreneurs constructed narratives that are multiplex in that they contain multiple potential ties to several customer groups. 
TABLE 12:

BUSINESS NARRATIVE MULTIPLEXITY

\begin{tabular}{|c|c|c|}
\hline COMPANY & $\begin{array}{c}\text { TIES TO PRIMARY } \\
\text { CUSTOMERS }\end{array}$ & $\begin{array}{c}\text { TIES TO SECONDARY } \\
\text { CUSTOMERS }\end{array}$ \\
\hline Alpha & $\begin{array}{l}\text { "Alpha, what we are is we're an } \\
\text { online tool that groups use to help } \\
\text { organize volunteering. Our secret } \\
\text { sauce is, it's primarily an affluent, } \\
\text { influential mom that's organizing } \\
\text { volunteering in her school, team, } \\
\text { scouts, church, health group. And } \\
\text { she's highly, highly desirable to } \\
\text { companies that want to reach her, } \\
\text { brands that want to reach her, and } \\
\text { she's very difficult to reach." } \\
\text { (Founder/CEO) }\end{array}$ & $\begin{array}{l}\text { "A lot of organizations rely on } \\
\text { volunteer leaders (committee } \\
\text { chairs, corporate captains, etc.) to } \\
\text { manage other volunteers. But } \\
\text { these volunteer leaders, while very } \\
\text { well-intentioned, don't necessarily } \\
\text { have the people or project } \\
\text { management skill set to be } \\
\text { successful in their volunteer roles. } \\
{[\ldots \text {... So if you can make it easier, }} \\
\text { structurally, for the leaders to } \\
\text { manage their volunteers, you can } \\
\text { keep your volunteer leaders and } \\
\text { volunteers happier." } \\
\text { (Founder/CEO) }\end{array}$ \\
\hline Beta & $\begin{array}{l}\text { "Our technology is so nimble and so } \\
\text { malleable; we have many, many } \\
\text { different touch points. We've yet to } \\
\text { find a business that we can't find a } \\
\text { way to make it work for. [...] we can } \\
\text { enable pretty much any } \\
\text { brand to start to measure and monetize } \\
\text { their giving process." (Founder/CEO) }\end{array}$ & $\begin{array}{l}\text { What we do is provide numerical } \\
\text { and QR codes for manufacturers } \\
\text { and consumer packaging } \\
\text { companies to print onto their } \\
\text { labeling [...] We provide a way } \\
\text { [for manufacturers] to gain a } \\
\text { direct communication channel to } \\
\text { their customers and, in a way, } \\
\text { kind of circumvent retailers in the } \\
\text { process." (Founder/CEO) }\end{array}$ \\
\hline Epsilon & $\begin{array}{l}\text { "Epsilon is revolutionizing the way } \\
\text { businesses engage in cause marketing } \\
\text { by making giving fun, easy, and } \\
\text { social." (corporate communication) }\end{array}$ & $\begin{array}{l}\text { "There's a dozen players online } \\
\text { that say 'we'll take donations } \\
\text { online for charities, we'll help you } \\
\text { raise money for X'. But the fact } \\
\text { that we say, 'we can do all of that, } \\
\text { it's not hard. And we'll also tie all } \\
\text { of your charities if you want to } \\
\text { something fun and to something } \\
\text { that's part of your lifestyle and } \\
\text { your hobby, it's a unique twist." } \\
\text { (Co-founder/CEO1) }\end{array}$ \\
\hline
\end{tabular}




\section{TABLE 12 (cont.)}

\begin{tabular}{|c|c|c|}
\hline Gamma & $\begin{array}{l}\text { "Gamma is a concept that solves the } \\
\text { business problem for restaurants. It's } \\
\text { focused in restaurants today. And the } \\
\text { reason it's focused in restaurants is it's } \\
\text { a massive market We spent over } 623 \\
\text { billion dollars last year in restaurants } \\
\text { just in the US. Which creates a } \\
\text { market of close to } 90 \text { billion problem } \\
\text { dollars for Gamma." (Founder/CEO) }\end{array}$ & $\begin{array}{l}\text { "You don't have to change your } \\
\text { daily routine. You don't have to } \\
\text { spend any additional money. } \\
\text { Gamma makes it free and easy to } \\
\text { get great offers and feed those in } \\
\text { need. Be a philanthropist for } \\
\text { hunger." (Founder/CEO) }\end{array}$ \\
\hline Lambda & $\begin{array}{l}\text { "Our software makes it easy for } \\
\text { agencies to accept and process } \\
\text { applications for social services. Our } \\
\text { customers are housing programs, } \\
\text { charter schools, churches, and } \\
\text { government programs." } \\
\text { (Founder/CEO) }\end{array}$ & $\begin{array}{l}\text { "We'd ... help governments and } \\
\text { charities modernize their case } \\
\text { management tools by offering } \\
\text { affordable software that'll help } \\
\text { them better communicate with } \\
\text { clients, drive down operational } \\
\text { costs and allow better } \\
\text { collaboration with other } \\
\text { organizations." (Founder/CEO) }\end{array}$ \\
\hline \multicolumn{3}{|l|}{$\begin{array}{l}\text { UNFUNDED } \\
\text { COMPANIES }\end{array}$} \\
\hline Rho & $\begin{array}{l}\text { "For years, fundraising platforms } \\
\text { stood between nonprofit and their } \\
\text { donors. Non-profits had to send their } \\
\text { donors to someone else's site. We take } \\
\text { a different approach. Rho brings } \\
\text { [nonprofit] fundraising back to [their] } \\
\text { own site." (Founder/CEO: Corporate } \\
\text { communication) }\end{array}$ & $\begin{array}{l}\text { Do not communicate ties to } \\
\text { multiple customer groups. }\end{array}$ \\
\hline Sigma & $\begin{array}{l}\text { Lack of business narrative hampers } \\
\text { creation of ties to customer groups. }\end{array}$ & $\begin{array}{l}\text { Lack of business narrative } \\
\text { hampers creation of ties to } \\
\text { customer groups. }\end{array}$ \\
\hline Omega & $\begin{array}{l}\text { "Omega is a fun, easy way for you to } \\
\text { turn social actions into social good. } \\
\text { Starting with Twitter (but soon } \\
\text { Facebook and more) you can pledge } \\
\text { an amount of money for each action } \\
\text { you take in a social network, and then } \\
\text { give it to your favorite nonprofits. All } \\
\text { the while you are unlocking coins, } \\
\text { discovering new nonprofits and causes } \\
\text { you might like to support, and helping } \\
\text { do everything from planting trees to } \\
\text { feeding the homeless." (Corporate } \\
\text { communication) }\end{array}$ & $\begin{array}{l}\text { Do not communicate ties to } \\
\text { multiple customer groups. }\end{array}$ \\
\hline
\end{tabular}


Returning to Alpha's communication, there are several examples of the founder describing the same underlying technology (and product) in multiple ways in order to create and appeal to multiple customer groups. Specifically, the business narrative addresses three customer groups: corporations, nonprofits, and individual volunteers that want premium services. For instance, in targeting nonprofits, the CEO describes the benefits of the product as follows:

A lot of organizations rely on volunteer leaders (committee chairs, corporate captains, etc.) to manage other volunteers. But these volunteer leaders, while very well-intentioned, don't necessarily have the people or project management skill set to be successful in their volunteer roles. This can be frustrating and time-consuming for both leaders and volunteers. So if you can make it easier, structurally, for the leaders to manage their volunteers, you can keep your volunteer leaders and volunteers happier.

In contrast, in an attempt to target corporate customers, the CEO describes the venture as a tool for corporations to reach consumers with their cause marketing messages. Moreover, in separate communication she explains that the technology also allows "large national organizations" to "reach the volunteer ranks."

Similar to the benefits of multiplex social-good narratives, using business narratives that contain multiple, potential ties to customers can help foster connections to a number of customer groups. This is advantageous to a firm for at least two reasons. First, and most obviously, more customer groups can translate into more potential customers. Second, by communicating multiple ways to frame a social enterprise this can increase the likelihood that an investor will understand and be attracted by the business problem the venture is trying to address. The influence of multiplexity on investors is described in the following section. 


\section{Investor Reactions to Narrative Multiplexity}

Investors' evaluations of funded social enterprises provide evidence that narrative multiplexity gives investors more than one opportunity to find something attractive about the business. That is, discussing multiple customer groups, each associated with a slightly unique business problem (or "pain point"), increases the likelihood that a given investor will consider the social enterprise as an attractive opportunity. This is important because, as an investor in Epsilon explains, "if you don't get the problem, then everything else doesn't really matter." In other words, the investor suggests that the quality of a venture's business solution is irrelevant if the investor being pitched to does not understand a customer's pain point. The investor explains, “[with] a lot of deals you invest because you get the pain point and whether it's your uncle dying of the same disease or whether you just like that it's a more creative way to do things, a big hurdle is understanding that there is an unmet need." He states that unsuccessful entrepreneurs assume that investors will understand and value every customer problem. In contrast, the successful social entrepreneurs communicate in such a ways that puts the investor in the "realm of understanding their customer's problem." Again, this suggests that providing links to multiple customer groups increases the likelihood that an investor will identify with one of the business solutions.

The statements of Alpha's investors provide evidence that they were attracted by the venture's appeals to different customer groups. For instance, some investors found Alpha's pitch to small and medium sized nonprofits most compelling. An angel investor 
from their most recent round of funding explains his connection to nonprofits as customers.

My company, Wirespring, works with thousands of nonprofits across the U.S. and we're always evaluating tools in the sector. It took about 5 seconds after evaluating Alpha to see that it's a homerun

In contrast, other investors focused on Alpha's "corporate" pitch, which is based on the idea that businesses will pay to use the site to advertise to their desirable user-base, affluent moms. Two other angel investors from the same angel network explain:

Alpha is an exciting investment opportunity [because] it is targeted towards a key group: parents who have busy schedules, want to support charitable or volunteer activities, and who have disposable income.

I thought having an audience of moms who volunteer at schools, which are highly affluent moms that spend a lot of money, is super valuable.

Still others were attracted to Alpha's ability to appeal to multiple customer groups. Another investor describes why he and other members of the angel group were attracted to Alpha.

We like their unique approach to both the mom-focused and cause-marketing markets - we think it's a great public service, and we also think it's a great business."

Finally, one investor associated with Alpha talked explicitly about why venture's with "messy solutions" - that is, business solutions that are complex enough that they can be pitched to appeal to multiple customer groups - are often evaluated more favorably than ventures communicating narrower, and albeit less "messy", solutions that focus on a single, clear customer group.

So we're investors in Twitter at VC Fund, and had someone actually come up with a solution to overthrow dictatorships, it likely would not be as successful. But instead, you have Twitter, which is also a cesspool for racism and hatred and Kardashians and all of this stuff. I've seen that play out many, many times: sometimes the messy solutions are the ones that are good, and what I've often seen in pitches from social entrepreneurs [...] is that they ignore the fact that solutions are actually really messy. 
Ultimately, using a "messy" multiplex narrative with multiple framings of the entrepreneur, the social mission, and the business, can provide investors with multiple elements that they can find attractive. Moreover, if the practice increases the number and diversity of the enterprise's customers, thus improving the firm's perceived financial sustainability, this will also make the venture more attractive to investors.

\section{Evidence That Unsuccessful Ventures Are Not Multiplex}

The three unfunded cases (Rho, Sigma, and Omega) did not possess narratives with multiplex ties. Instead, their communication is constructed from personal, social, and business narratives that contain singular descriptions of the founders, social-good, and business, which then link the narrative to single customer and beneficiary groups. Thus they do not provide opportunities for multiple beneficiary and customer audiences to connect with their venture.

\section{Non-multiplexity of personal narrative}

Omega's communication provides an example of non-multiplexity. As previously described, Omega's founders made the conscious decision not to develop their personal narratives and to instead create a collection of cartoon characters to be a focus of their communication. The characters were whimsical -a samurai, a Zulu chief, a chicken dressed as a Mexican wrestler - but they did not have well-developed personalities nor did they have (fictional) background experiences. Thus it is not clear how a customer group, let alone multiple customer groups, would have connected with these characters. If instead, each of the characters had represented an important customer or beneficiary group (e.g. a "slacktivist" college student, one of their main customer demographics; or a 
nonprofit manager, their beneficiaries) then perhaps this strategy would have found more success. But, as the founder admits, the characters never gained any traction with customers or beneficiaries.

Omega, and their communication strategy, can be contrasted with Epsilon, a funded venture. Epsilon provides a product that is almost identical to what Omega offers. Both firms created a way to tie donations to online activities. There are significant differences, however, in the multiplexity of their narratives. These differences are most clear in comparisons of their personal and business narratives.

In crafting and communicating his personal narrative, Epsilon's primary founder (and first CEO) creates potential ties to multiple stakeholder groups. For instance, he emphasizes certain work and non-work experiences, which have connections to the nonprofit sector.

Post-college, my wife and I ended up in Europe for a couple of years assisting refugees and immigrants. Anyone that's ever worked with a nonprofit or charity has said things like "If only we had this cash, we could do ..." and while overseas, we definitely had our share of those moments.

Nonprofits are the primary beneficiaries of the venture's activities. Moreover, the problem he describes experiencing ("If only we had cash ...") is the exact problem he is trying to address for nonprofits (i.e. nonprofits generally receive the lion's share of their donations around the holidays leaving them strapped for cash during the year). Moreover, he communicates that all of the company's founders have ties to the nonprofit world, which creates further connections to their primary beneficiaries.

All four of the founders of Epsilon come from non-profit, philanthropic backgrounds $[\ldots]$ we all wanted to make the world a better place, we were hippies and nerds wanting to create something special using our technology skills 
These connections are important because one of the founders' main strategies for attracting users is to rely on its beneficiaries (i.e. nonprofits) to promote and advertise the social enterprise. Thus, it is important for the venture to create a strong connection with this group. Similarly, one of Epsilon's other co-founders, who serves as the current CEO, also communicates a personal connection to the nonprofit sector and to one nonprofit in particular.

The incubator-like machines delivered from the March of Dimes saved my daughter's life when she was born prematurely. Then I had a set of twin girls born two years later, six weeks premature again, and they were put in the same machines. Now they are all fine and healthy. Through this experience I realized money can do a lot of great things. I'm so thankful for the March of Dimes that I participate in their walk-a-thons every year, but I started to wonder how I can leverage technology to help non-profits realize a greater impact?

With these statements Epsilon's leadership is communicating that they have first-hand experience with the nonprofit sector, are motivated to serve it, and understand its plight.

Epsilon's founder also uses his personal narrative to form a connection to business stakeholders. To do so, he focuses on the business-related experiences in his background.

I spent about six years with IBM, working on analyzing threats to the Internet at large. There I did a ton of very high-level stuff. I founded a security intelligence group and did some really cool things.

Communicating that he has prior experience in the business world not only helps to establish his legitimacy but it also can serve as an experiences with which corporate stakeholders - one of Epsilon's main customer groups - can identify. Moreover, depending on their background, investors may also be more likely to identify with these, 
business-related experiences, than if the founder just described his connection to the nonprofit sector.

Finally, the founder also communicates information that could be used to form ties to others in the social enterprise sector or to those who support the sector. He draws on both early experiences and his personal passion for social entrepreneurship to create this potential connection.

One of the things that I had the privilege to do was that I got hired at a local church camp where I just mowed the lawn and did counseling for kids during sports and life guard - just summer camp stuff. And it really instilled in me that I can do something, and make money, and have fun, but still do good.

I love it [social enterprise]. Because at the end of the day I get to feed my family, have a roof over my head, and change the world. That's hard to argue with. Definitely I could go back to IBM and make twice the money I'm making now, but it would be hollow and boring again.

The sentiments expressed in the second quotation, about being able to "make twice the money" in a corporate career but the work being "hollow and boring," is a common theme in social enterprise and would likely resonate with social entrepreneurs or advocates of the sector.

Together, each of the personas communicated - "business guy", "nerd", "nonprofit supporter", "social entrepreneur" - represent a different way to frame who the entrepreneur is. In turn, each framing represents a unique opportunity to create a connection to a group of stakeholders.

Omega, in contrast, which possesses the same business model as Epsilon, did not utilize the founders' personal narratives. They did, however, develop social-good and business narratives. However, these narratives were narrow and described the business 
model and social component of the venture as only being able to influence one customer and beneficiary group. That is, they did not construct flexible narratives that appealed to multiple stakeholder groups. For instance, their business narrative, describing their business model, solution, and customers, focused exclusively on one customer group, individual consumers.

In contrast, in Epsilon's communication, and particularly their business narratives, they describe the use of their product broadly and explain how it can be used not just by individual consumers but also by other groups such as corporations and nonprofits. Even though individuals, nonprofits, and corporations make use of the same product, Epsilon constructed a narrative that corresponds to each of these customer groups. In fact, the CEO attributes a portion of their success to their ability to appeal to, and form connections with, multiple customer groups.

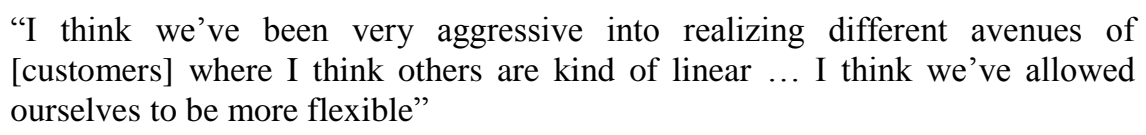
[customers] where I think others are kind of linear ... I think we've allowed ourselves to be more flexible"

In contrast, Omega's founders treated the choice of customer groups as an "either-or" decision. All three admitted that rather than developing a narrative that was flexible enough to appeal to all three groups, they went back and forth regarding which group should be the (exclusive) focus of their communication.

\section{Summary}

In this chapter I present evidence that, in addition to utilizing two narrative tactics (tailoring and linking) the narratives of successful social ventures also shared a common characteristic: multiplexity (represented graphically in Figure 3). 


\section{FIGURE 3:}

\section{NARRATIVE MULTIPLEXITY}

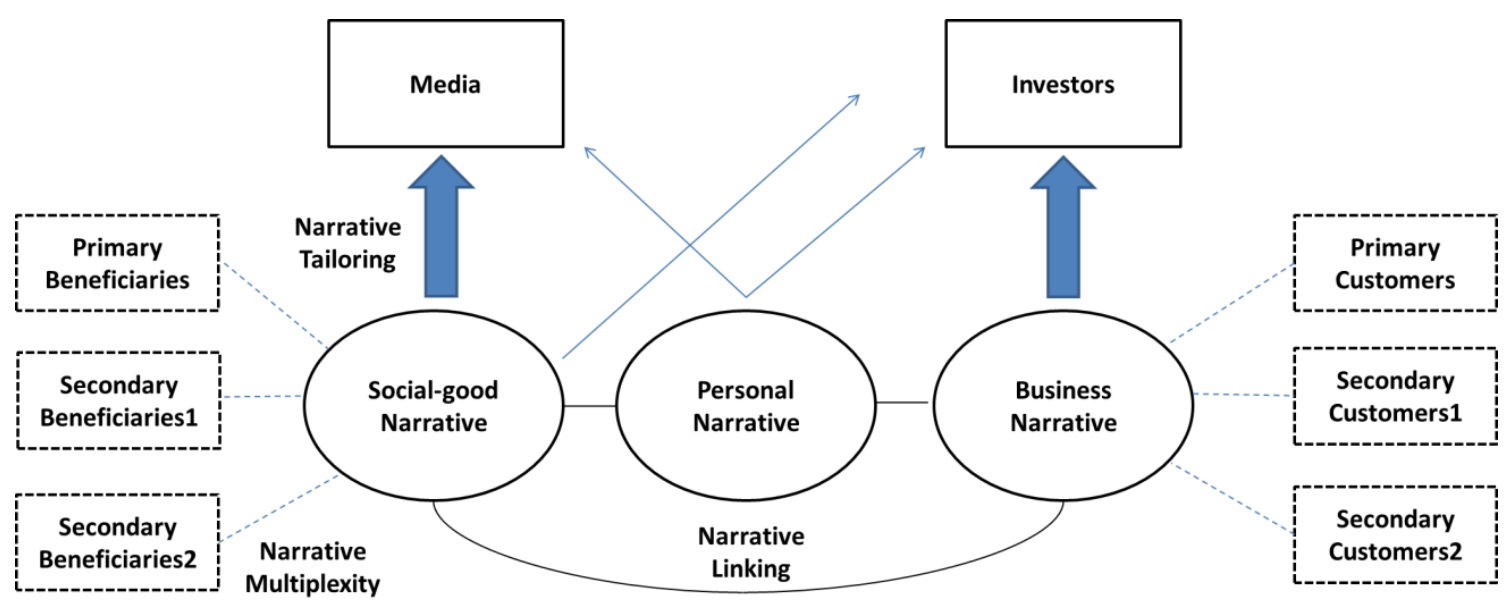

The successful social enterprises constructed narratives - personal, social-good, and business - that contained multiple, non-overlapping, potential ties to more than one customer and beneficiary group. They did so by including in their narratives multiple ways to frame the focal entrepreneur, the social mission, and the business component of the venture. This provided customers, beneficiaries, and investors with a number of possible connections (or "touch points" to the venture), which increased its attractiveness and in the case of investors, their willingness to provide resources. In contrast, the unfunded social ventures constructed narratives that did not attempt to connect with multiple stakeholder groups. Instead, their narratives contained a singular framing intended to appeal to one customer and beneficiary group. 


\section{CHAPTER 9:}

\section{DISCUSSION}

This study explores how social entrepreneurs acquire the resources needed to grow their ventures. As discussed, prior research has not examined the topic of resource acquisition by social entrepreneurs nor has it explored specifically how such entrepreneurs can use narratives in seeking resources. To explore these topics, this dissertation focuses on the narratives entrepreneurs communicate to external investors.

The research contributes to the social enterprise literature in four ways. First, a typology is created of the generalized types of narratives used by social entrepreneurs. The dominant themes and characters of these narratives are identified. Specifically, I demonstrate the existence of three narrative-types (personal, social-good, and business) and describe their unique, constitutive elements. Moreover, I explore how these narrativetypes serve as the buildings blocks for social entrepreneurs' communication with external stakeholders, particularly investors and the media.

Second, this study suggests that social enterprises successful in attracting external investment deploy their narratives differently than unsuccessful ventures. Successful enterprises engage in narrative tailoring, which is adapting the emphasis of a narrative to match the interests of a particular audience. Specifically, when communicating with investors successful social entrepreneurs tailor their narrative communication to focus on their business narratives. When communicating with other resource providers, such as the media, successful entrepreneurs emphasize personal and social-good narratives. 
Third, the findings of this study illustrate that, rather than using the narrativetypes in isolation, social entrepreneurs can utilize different combinations of the three narratives. Evidence is presented of how narratives can be linked, what information is contained in such narratives, and what purposes linking can serve. Specifically, I find that when communicating with investors, successful social entrepreneurs utilize a dominate business narrative linked with components of their social-good and personal narratives. Linking business and personal narratives can introduce information (e.g. prior work and life experiences) that can help an entrepreneur engender credibility, demonstrate their passion, and inspire confidence with investors. Similarly, linking business and socialgood narratives can increase investor attention, differentiate the enterprise from competitors, and create opportunities for overlap between investors' beliefs and values and the enterprise's social mission.

Finally, in this study I provide evidence that an important characteristic of social enterprise narratives is their multiplexity - i.e. multiple, potential ties to more than one audience. Multiplex narratives contain several ways to frame the social venture, which creates numerous, possible connections to customers and beneficiary groups. Successful social enterprises craft multiplex personal, social-good, and business narratives containing multiple framings of the entrepreneur, the social mission, and the business, which provide investors and other resource providers with several elements they can find attractive. In contrast, unsuccessful ventures construct narratives containing singular framings of the venture and its founders. Thus their communication only contains potential linkages to single customer and beneficiary groups. 
Taken together, this study develops a framework to explain how variations in narrative construction and deployment can influence variations in social enterprise resource acquisition success. In doing so, it suggests that differences in social entrepreneurs' communication tactics and characteristics can explain why some social entrepreneurs are successful in acquiring resources and others are not.

In addition to its contribution to the social enterprise literature, the findings and framework developed also contribute to the two other main literatures the study draws upon: organizational narrative theory and entrepreneurial resource acquisition.

\section{Implications for Organizational Narrative Theory}

First, as discussed in chapter 2 (and in more detail in Appendix B), there is an extensive body of research examining organizational narratives. Although this research has explored several topics involving narratives, such as their role in organizational identity (Ibarra \& Barbulescu, 2010), power dynamics (Brown, 1998), legitimacy (Golant \& Sillince, 2007), and learning (Garud et al., 2011), this study sheds light on several important features of organizational narratives that are heretofore unexamined.

First, prior work has acknowledged that multiple narratives can exist within an organization (e.g. Humphreys \& Brown, 2002). For example, for a given organizational event, such as an acquisition, there may be an "employee" narrative, a "top-management" narrative, and a "customer" narrative, which are developed by each of these groups and represent their attempts at making sense of (or politicizing, legitimizing, controlling) the

event. Since these groups have different interests, their narratives are often conflicting and inconsistent. Extant research has not, however, explored how a single group in an 
organization (e.g. the founders) can construct and deploy multiple, consistent narratives. The evidence presented in this study suggests that social entrepreneurs create three primary narrative-types, which they use to emphasize different - but non-conflicting facets of their venture to different audiences.

Second, in not focusing on firms' ability to construct multiple consistent narratives, prior research has not examined how such narratives can be linked. Thus it is not understood what effect linked narratives can have on an organization's audiences. This study reveals that not only can narrative-types be combined but that doing so can increase the persuasiveness of communication with resource providers.

Third, although there is a small body of work which has acknowledged that individuals understand time in terms of narratives (e.g. Cunliffe, Luhman, \& Boje, 2004; Shipp \& Jansen, 2011), there is limited work examining how an organization's narratives change over time. Moreover, the effect that temporal dynamics have on narrative persuasiveness is also previously unexplored. Preliminary evidence from this study (presented in Appendix A) suggests that not only can a firm's narratives change over time but that an organization's position on the evolutionary path of their narratives can influence their ability to acquire resources.

\section{Implications for Entrepreneurial Resource Acquisition}

Prior research on resource acquisition has identified several factors that can influence a new venture's ability to acquire resources and, more specifically, to secure external investment. These factors help a firm to overcome uncertainty, information asymmetry, and the liability of newness that is associated with being a new venture and 
that makes resource providers reluctant to commit resources to a young firm (Schoonhoven and Romanelli, 2001; Hellmann, 2002; Zott \& Huy, 2007). This study's findings reaffirm the importance of several of these factors. For instance, social entrepreneurs used their social networks, and particularly ties to high-profile investors and board members to influence resource providers. In addition, they attempted to legitimize their ventures by engaging in actions to signal their personal and organizational quality.

Social entrepreneurs also used stories to influence investors' interpretations of their ventures. But the findings of this study do not fully affirm the findings of Martens et al.'s (2007) study on entrepreneurial storytelling and resource acquisition. In particular, whereas Martens and colleagues found that narratives conveying unambiguous identities and that were less complex (i.e. had a less dense "story-map" of rationales) were associated with increased ability to acquire resources, this study produces evidence to support a different finding. The social enterprises that were successful resource acquirers constructed narratives that contained some ambiguity about the firm's identity. For instance, narratives were often ambiguous about key questions such as, what beneficiaries and customers is the enterprise targeting? As explained, by doing so the narratives possess a degree of flexibility which allows for the creation of ties between the narratives and several different audiences. Similarly, successful social entrepreneurs' narratives also contained some ambiguity about the firm's identity. For instance, is the firm a profit-driven business (i.e. what is communicated to investors) or an impactfocused social enterprise (i.e. what is communicated to other stakeholders)? As the CEO 
of Alpha described, "if you want me to be a social enterprise, that's fine, or if you want me to be a sick viral mom tool, then I can be that too." This ambiguity allowed for connections to be formed with multiple resource providers. Also, as described in Chapter 7, a certain degree of narrative complexity was also beneficial to social entrepreneurs. Drawing on a similar mechanism, more complex - and more "messy" - narratives, with multiple rationales for the venture's initiatives, provided multiple touch points to appeal to different investors (and to different kinds of investors).

In addition to reaffirming findings from prior work on entrepreneurial resource acquisition and providing nuance to other findings, this study also uncovers new, previously unexamined factors that can influence resource acquisition. The factors include narrative tactics, such as tailoring and linking and characteristics such as multiplexity. In addition, much of the prior work on resource acquisition examines it as a dichotomous outcome (i.e. a firm receives angel or VC investment or it does not) or by the dollar amount of the investment. In contrast, this study captures the perceptions, evaluations, and beliefs that undergird investors' decisions. By paying more attention to the investor's perspective, several insights and nuances are revealed about the thoughtprocesses that investors engage in when evaluating social and traditional ventures.

\section{Other Theoretical Implications}

This study also has implications for two other areas, which are at the intersection of management, organization theory, and entrepreneurship: research on institutional logics and on the role of emotion in stakeholder evaluations.

\section{Implications for Institutional Logics}


Organizational forms are the structural manifestations of institutional logics (Rao et al., 2000). Social enterprises represent an organizational form that fosters two dominant logics: social and economic (Nicholls, 2010). As this study illustrates, juggling multiple, often conflicting logics, means that social enterprises must not only achieve operational co-existence of their logics (i.e. balancing logics in the activities of their organization) but must also develop a proficiency in communicating about these logics to stakeholders that are often rooted in one logic or another.

Moreover, this study builds on recent work on institutional logics by Battilana and Dorado (2010). In their study, they explore how two micro-finance organizations were able to maintain their hybrid nature (i.e. to balance competing logics). They sought to understand the type of employees hybrid organizations should hire and how they can socialize their members into displaying a desired set of behaviors and values so as to build and maintain their "hybridity". They find that a tabula rasa hiring approach, which targets individuals not steeped in either of the organization's competing logics, may help a hybrid organization to reduce the influence of its institutional environment and thereby provide more freedom for socialization policies to influence the process of identity building.

Battilana and Dorado's findings suggest that a social enterprise's multiple logics can influence at least one type of resource, human capital. In this study, I find that the existence of multiple logics can influence other resources as well, such as those provided by investors and the media. Moreover, the findings shed light on the factors that lead social entrepreneurs to embrace one logic over another (e.g. prior life experiences). They 
also help us to improve our understanding of how organizational actors communicate to resource providers about competing institutional logics. Understanding how social entrepreneurs use strategies such as narratives to navigate the tension between their logics and between the effects of these logics on different stakeholder groups has uncovered insights into how other types of organizations can balance multiple logics, communicate about them to resource providers, and leverage them as additional elements of their “cultural toolkit” (Swidler, 1986; Rindova et al., 2011).

\section{Implications for Emotion and Stakeholder Evaluations}

As this study illustrates, narrative differences are associated with some firms receiving more favorable stakeholder evaluations than others. However, unlike other studies (e.g. Martens et al., 2007), which focus exclusively on narrative's ability to influence cognition-based constructs, such as categorization, this study begins to shed light on how narratives can influence resource acquisition through affective (i.e. emotional) mechanisms. For instance, although investors claimed to evaluate social enterprises based largely on analytical, "business-focused" criteria, they also revealed that their decisions were at least partially informed by emotional factors such as whether or not a venture's social mission resonated with their values and beliefs. Moreover, it can be argued that one of the reasons that the media prefer featuring social entrepreneurs' social-good and personal narratives is because such narratives are more likely to inspire an emotional response in the consumers of the media (e.g. Rindova, Pollock, \& Hayward, 2006). The successful entrepreneurs recognized this and tailored their narratives 
accordingly (e.g. by including elements of their more emotion-based social-good narratives).

In addition, the study's findings suggest that the emotion conveyed through social enterprise narratives can serve several roles, including capturing investor (and media) attention and creating awareness, influencing investors' beliefs and perceptions, creating connections between social enterprises and funders and, ultimately, influencing investors' decision to commit resources to the organization. In general, the lack of attention in prior research to narrative's ability to influence investors' evaluations through emotion is representative of a more general omission in management research: an absence of studies considering the role of affect in firm evaluations (Tetlock, Saar-Tsechansky, \& Macskassy, 2008; for an exception, see Pfarrer, Pollock, \& Rindova, 2010). Thus the current study begins to shed light on a largely ignored aspect of narratives and organizational research.

\section{Implications for Social Entrepreneurs}

In addition to its theoretical implications, this research also has normative implications for social entrepreneurs. First, and most generally, findings suggest that social entrepreneurs should approach narrative construction and deployment purposively not haphazardly. Crafting the narratives used to communicate about the key facets of a social venture to stakeholders is not "just" storytelling; rather, as this study's findings suggest, it is an activity that can have significant implications for a venture's ability to acquire resources. 
Second, beyond merely being conscious of the use of narratives, social entrepreneurs also should not underemphasize the importance of being strategic about how they are communicated to different audiences. In particular, it is important for social entrepreneurs to realize that as powerful as their social-good narrative might be, not every audience wants to hear about it. There are indeed some audiences where the social-good narrative should dominate the conversation (e.g. media, certain customer or employee groups). However, investors, or at least traditional angel and VC investors, are not such an audience.

In addition to not using the firm's social-good narrative with all audiences, perhaps the most important finding of the study is the importance of developing a compelling business narrative. Put simply, social enterprises without a compelling business narrative did not receive funding. This was perhaps the most consistent theme emphasized by investors and successful entrepreneurs. Indeed, one founder has the following opinion about getting external investment.

The money's the easy part. I used to laugh at it, but the reality is now I totally buy that. You have a good business model. You check all the boxes; you focus on being a good entrepreneur, running a strong business, and the money will come. But if you focus on the [social] impact, the benefit, then you're putting the cart before the horse. (Founder; Beta)

Unfortunately, many social entrepreneurs make this very mistake. They focus almost exclusively on the social-good narrative while their business narratives languish. This mistake is propagated by the debate that is prominent in the practitioner literature about whether social entrepreneurs should emphasize their social or economic messages. The problem with this debate is that it suggests that social entrepreneurs must choose one narrative-type or the other. Since, their social mission is often foundational to the creation 
of the venture (and, as described, may even be fundamental to their personal identities), if faced with the choice, it is not surprising that entrepreneurs choose their social-good narratives.

Findings also indicate that social entrepreneurs can be reluctant to invest in their business narratives for several other reasons, such as an aversion towards business, a background in social services that makes them more comfortable developing the socialgood narrative, the belief that as a "social enterprise" the business narrative is unnecessary, and the (mistaken) assumption that as a social enterprise their venture will be evaluated by investors using a different "scorecard" than traditional new ventures ${ }^{17}$. However, one of the most consistent pieces of feedback from investors, related to why they invested in ventures or chose not to invest, is the importance of communicating a compelling business narrative. Thus it is critical for social entrepreneurs to develop such a narrative to use with investors.

Third, although it is generally not as critical with investors as the business narrative, social entrepreneurs should not under-invest in the development of their personal narratives. As the study's findings illustrate, personal narratives can serve many functions, including conveying passion, competence, and legitimacy and helping to create connections to stakeholder groups. Social entrepreneurs should, therefore, invest in developing their personal narrative and in understanding how to link it to the other narrative-types.

\footnotetext{
${ }^{17}$ In fact, several investors suggested that they evaluate social enterprises harder than traditional new ventures because they assume that the social component is going to somehow be a detriment to the entrepreneurs' ability to generate profits and a return on investment. Thus social entrepreneurs may actually have to work harder than their traditional counterparts to convince a funder to invest.
} 
Interestingly, the personal narrative is the one narrative-type explicitly valued by the two resource providers considered in this study. That is, there is evidence to suggest that both the investors and media are influenced by personal narratives (whereas the media seems relatively uninfluenced by business narratives and investors are only marginally influenced by social-good narratives). Moreover, entrepreneurs should not feel that it is somehow inappropriate to develop their personal narratives - as if to do so is to place oneself at the center of the venture where beneficiaries or customers should be. Entrepreneurs with this mindset are giving up an important avenue for connecting with multiple stakeholder groups.

Fourth, this study's findings also suggest it is important for social entrepreneurs to consider how their business and social-good narratives are linked. This can help them to make sense of and to understand how the business and social "sides" of their venture are connected. Moreover, it is important for entrepreneurs to think of the two components of their venture as related. Many social entrepreneurs view the business side of their social venture as merely a revenue generator (or "cash cow"), which exists to fund their creation of social-good. Thus, their business model is viewed as a sort of "necessary evil", which the entrepreneur tolerates in order to fulfill the goals of the social mission. But, like failing to develop a personal narrative, treating the business side of the venture as little more than a means to an end rather than as a critical and interdependent component of the venture that can have a synergistic effect with the social mission, is a missed opportunity. To reiterate one investor's view:

Really the best ones [social enterprises] are going to be ones where the social good makes it a better damn investment. Where it's not a sacrifice that it's a 
social good. It's actually going to work way better. [The social mission] isn't a deficiency. It's not a sacrifice. It's actually better for it. It's [...] a real business, and actually, it's going to grow faster and get bigger because it has these other qualities. [The social mission] actually makes it stronger.

Finally, this study suggests that social entrepreneurs should strive to conceive of and communicate about their business models and social-problem solutions broadly. The successful social entrepreneurs did not "pigeon-hole" themselves with limited narratives that described the venture in very narrow terms. Rather, they tried to cast the widest net possible and communicate about all of the potential customer groups and beneficiary groups that could be served by their venture.

\section{Future directions}

Findings from this study suggest several areas for additional work. First, it is important to determine if the findings described here are supported in a study using deductive logic and a larger sample of social entrepreneurs. Moreover, the findings should also be validated in non-technology focused industries and with social entrepreneurs operating outside the developed world. The latter is particularly important because there is evidence to suggest that funding may operate differently in emerging economies.

In particular, entrepreneurs and investors recounted that developing world social entrepreneurs have more access to social-impact investors - i.e. angels or VCs who place a much higher premium on a venture's social mission. There is evidence to suggest that this investor class has a different preference-ordering for the criteria they use to evaluate social enterprises. However, does this mean that entrepreneurs pursuing this type of investment should simply place greater emphasis on their social-good narratives? Or, do 
these entrepreneurs' resource acquisition strategies need to be more nuanced? Since social enterprise founding rates in developing counties are in many cases higher than in developed countries, and since "impact investors" seem to be an increasingly important investor class, gaining a better understanding of resource acquisition in these settings is an important next step.

In addition, the findings of this study could also be examined in the context of traditional new ventures. The purpose for doing so would be to understand if the narrative tactics (e.g. tailoring, linking) and characteristics (e.g. multiplexity) found to be important in the social enterprise sector are in fact generalizable to all entrepreneurs.

Second, this study focused on social enterprises' external stakeholders. However, it is important to understand how the narrative tactics and characteristics described influence firm's internal stakeholders. For instance, evidence from informants suggests that entrepreneurs' social-good narratives may influence their ability to attract employees. Indeed, entrepreneurs suggest that their social mission narrative gives them a distinct advantage in the labor market over firms without such narratives (e.g. they describe having an easier time hiring and retaining top-quality talent). Thus, future research could reveal interesting insights about the internal dynamics of narrative communication. Moreover, building on the typology created in this study, research could also explore how these social enterprise narratives influence and interact in non-resource acquisition situations (e.g. employee dynamics).

Third, a recurring theme was that some social entrepreneurs expressed a clear preference for the social-good narrative and an aversion towards constructing business 
narratives. In contrast, others expressed comfort in communicating both messages. This is an important individual-difference in the social enterprise sector that drives a variety of decisions beyond those related to resource acquisition. Future research could build on the preliminary insights uncovered in this study to gain a better understanding of why some entrepreneurs have such an affinity for one logic over the other.

Fourth, this study has focused on one measure of new venture success: the ability to attract outside investment. Securing external funding is an important outcome and one that plays a significant role in the survival (and failure) of a new venture. It also captures other forms of success (e.g. sales). However, it is not the only measure of entrepreneurial success. For instance, one might instead measure other performance-related outcomes, such the venture's number of customers, or in the case of social enterprises, the number of beneficiaries served. Beyond the influence of social enterprise narratives on getting investment, future research is needed to understand what the ramifications are of social entrepreneurs' narratives on other types of organizational performance.

Fifth, and finally, because of the important role given to narratives by the practitioner literature and the social entrepreneurs interviewed, this study focused exclusively on narrative communication. However, there are other, non-narrative forms of communication. In fact, similar to the debate in the practitioner literature about what type of narrative is most effective ("economic" or "social") there is another debate about what type of information is most persuasive: narrative or non-narrative. As one entrepreneur explains: "Metric-heads insist on quantitative measures that "prove" an initiative's ROI, while story-huggers opine that numbers can't ever convey the value of 
lives transformed. Who's right?" (Moore, 2011). Future research is needed to clarify how non-narrative communication is used in social enterprise resource acquisition and whether narratives, are, in fact, more or less compelling. 


\section{CHAPTER 10:}

\section{CONCLUSION}

This dissertation examines social enterprise resource acquisition. It begins by reviewing the literatures on social entrepreneurship, entrepreneurial resource acquisition, and the use of narratives in resource acquisition (a detailed review of the narrative theory literature is also included in Appendix B). These reviews produce several insights. First, despite evidence to suggest that social entrepreneurs have a particularly difficult time acquiring resources, social enterprise research has not sought to understand social venture resource acquisition. Second, social enterprises differ from traditional new ventures in several key ways which suggest that research developed from examining traditional entrepreneurial resource acquisition is unlikely to fully apply to social entrepreneurs. Third, prior research (and the practitioner literature, reviewed in Appendix C) has hinted that narratives may play a particularly important role in social enterprise resource acquisition. However, organizational researchers examining narratives have not explored their role in social enterprise.

The empirical and theory-building portions of this dissertation attempted to fill these omissions in the social enterprise, resource acquisition, and organizational narrative theory literatures and to generate new insights. In particular, I sought to answer two questions: What narratives do social entrepreneurs construct? And, how do social entrepreneurs use narratives in resource acquisition? To examine these questions I used an inductive, theory-building approach, based on a pilot study (described in Appendix C) 
and two main studies. Study 1 consisted of interviews with 75 entrepreneurs, investors, and ancillary participants in the social enterprise sector. In Study 2, I construct case studies of eight technology-focused social ventures using 34 additional interviews and archival data.

The primary result of both studies is a longitudinal framework to explain how variations in narrative construction and use can influence variations in social enterprise resource acquisition success. Specifically, the framework explains how differences in social entrepreneurs' communication tactics and characteristics can explain why some social entrepreneurs are successful in acquiring resources and others are not. Overall, this study found that successful social enterprises constructed three narrative-types (personal, social-good, and business narratives). These narrative-types served as the buildings blocks for social entrepreneurs' communication with resource providers, and particularly investors and the media.

In addition, successful social entrepreneurs engaged in two tactics: narrative tailoring (i.e. adapting the emphasis of a narrative to match the interests of a particular audience) and linking (i.e. utilizing different combinations of the three narrative-types). The narratives of successful social entrepreneurs also shared a common characteristic: multiplexity (i.e. they contained multiple, potential ties to more than one audience).

In addition to its implications for the literature on social enterprise, the study also contributed to work on two other topics of research: entrepreneurial resource acquisition, and organizational narrative theory. First, the findings contribute to the resource acquisition literature by uncovering new and previously unexamined factors that can 
influence resource acquisition (i.e. tailoring, linking, multiplexity). Similarly, the framework contributes to organizational narrative theory by shedding light on several features of narratives that play a key role in resource acquisition but that are heretofore unexamined.

The framework developed in this study also has ties to two other literatures: institutional logics and emotion in firm evaluations. First, the study contributes to the literature examining competing logics by improving our understanding of how social entrepreneurs use strategies such as narratives to balance multiple logics and communicate about them to resource providers. Second, the findings also contribute to work on emotion in stakeholder evaluations by exploring how narratives can influence resource acquisition through affective (i.e. emotion) mechanisms.

Overall, this study is a step in the direction of developing a better understanding of how social entrepreneurs acquire resources and use narratives. It suggests that the narratives constructed and deployed by social entrepreneurs are not insignificant pieces of communication. Indeed, they can play an instrumental role in social enterprise resource acquisition. Thus, it is important for scholars of social enterprise and social entrepreneurs to be mindful of the power and persuasiveness of narratives.

Social enterprise is an increasingly vital component of society. It is, therefore, important to understand what elements of traditional models of organization apply to this organizational form and what features of social enterprise will require novel theoretical insights. In essence, we must ascertain how much of the "plot" of social entrepreneurship 
has been revealed in the narrative of traditional enterprise and how much is a new and untold story. 


\section{Appendix A:}

\section{How Do Social Enterprise Narratives Change Over Time?}

In Chapters 6-8, I describe how the narratives of successful social enterprises differ in the three key ways from unfunded social ventures. Specifically, funded entrepreneurs engage in narrative tailoring (emphasizing different narrative-types with different stakeholder groups) and linking (combining narrative types). They also construct narratives that contain multiplex, potential connections to stakeholder groups. In addition to these tactics and characteristics, there is preliminary evidence that an additional commonality between the narratives of the funded ventures that is not shared by the unfunded ventures: narratives of successful ventures underwent a common evolution after founding. In particular, successful enterprises progressed through three narrative phases.

Narrative phase 1 corresponded to the earliest stages of the ventures, often the "idea-phase" (Andries \& Debackere, 2006). During this phase, in both funded and unfunded ventures, social-good narratives dominated. That is, entrepreneurs' social narratives were significantly more developed than their personal and business narratives (the development and relative importance of each narrative-type is represented in Figures 4-6 by its size relative to the other narrative-types). Indeed, during phase 1, business narratives were often entirely undeveloped (i.e. the entrepreneur had not begun to develop a business case for his venture). Moreover, while entrepreneurs possessed a personal narrative - everyone does - they often could not clearly communicate how their 
personal experiences informed their social enterprise. Thus there were no linkages between the personal and other narratives (i.e. narrative linking was not present). Also, since the entrepreneurs did not possess compelling personal or business narratives they would communicate their social-good narratives to all audiences (i.e. they were unable to engage in narrative tailoring). Finally, during phase 1, the enterprise was likely to have a single primary beneficiary group: the most obvious benefactors of the enterprise and often the group that inspired the entrepreneur to address the social problem ${ }^{18}$. Moreover, if the enterprise had a fledgling business narrative it was likely only connected to one customer group (i.e. narrative multiplexity was non-existent).

FIGURE 4:

NARRATIVE EVOLUTION - PHASE 1

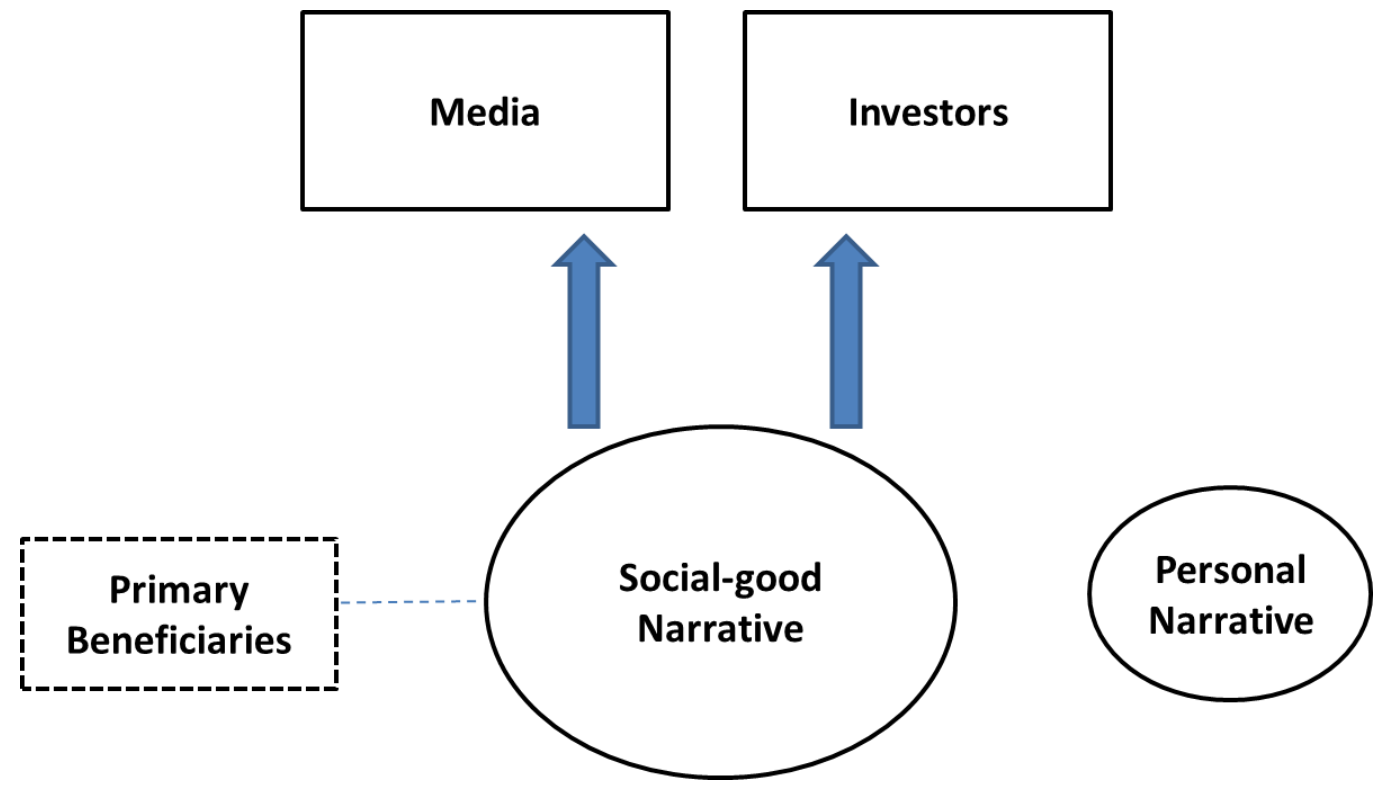

\footnotetext{
${ }^{18}$ At this phase, a venture may not have had a business narrative, but they still had a business and were thus a social enterprise (rather than a nonprofit or a charity). However, they had not developed a narrative about the venture's business model, solution, revenue, customers, etc.
} 
In phase 2, for successful entrepreneurs the relative importance of the narrative types changed. In particular, the ventures' not possessing a business narrative developed one (or if they had a fledgling business narrative it became significantly more developed). Thus, the business narrative became relatively more important than in phase 1 . However, in many cases, the social narrative was still dominant. But since most successful entrepreneurs had all three narratives available at this phase, they started to emphasize different narrative-types with different stakeholder groups (i.e. to engage in narrative tailoring). In addition, successful enterprises also began to develop connections between their narrative-types (i.e. to engage in narrative linking). Moreover, since the social narrative was now more complex, successful entrepreneurs had identified multiple beneficiary groups to appeal to. But since their business narrative was nascent, many still focused on one customer group.

\section{FIGURE 5:}

\section{NARRATIVE EVOLUTION - PHASE 2}

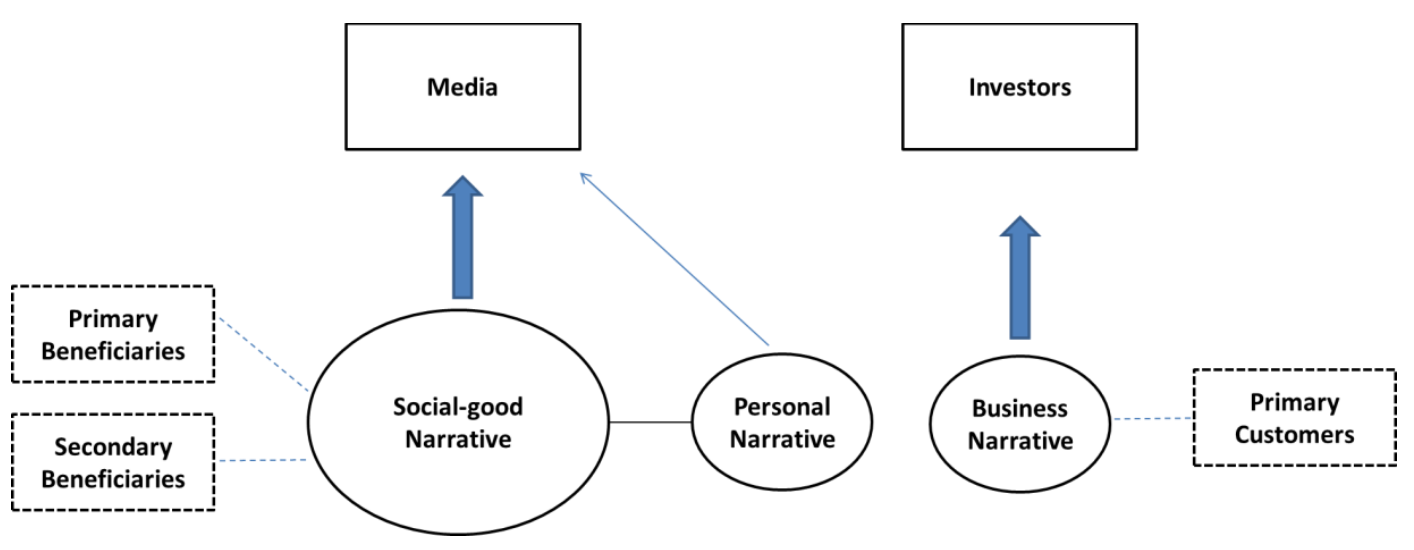


In phase 3, successful entrepreneurs had fully developed business, social-good, and personal narratives. Moreover, the business narrative was now equivalent in importance to the social narrative. Communication was tailored so that the social-good narrative was emphasized with media sources. This communication was also linked with elements of the other two narrative-types and particularly the personal narrative. The business narrative was emphasized with investors. But it too was linked with elements of the other two narrative-types. In addition, the social-good narrative was now broad enough that it could support a multiplexity of potential ties to beneficiary groups. Likewise, the business narrative contained potential connections to multiple customer groups. Amidst these groups, the enterprise still maintained ties to primary customer and beneficiary groups.

\section{FIGURE 6:}

\section{NARRATIVE EVOLUTION - PHASE 3}

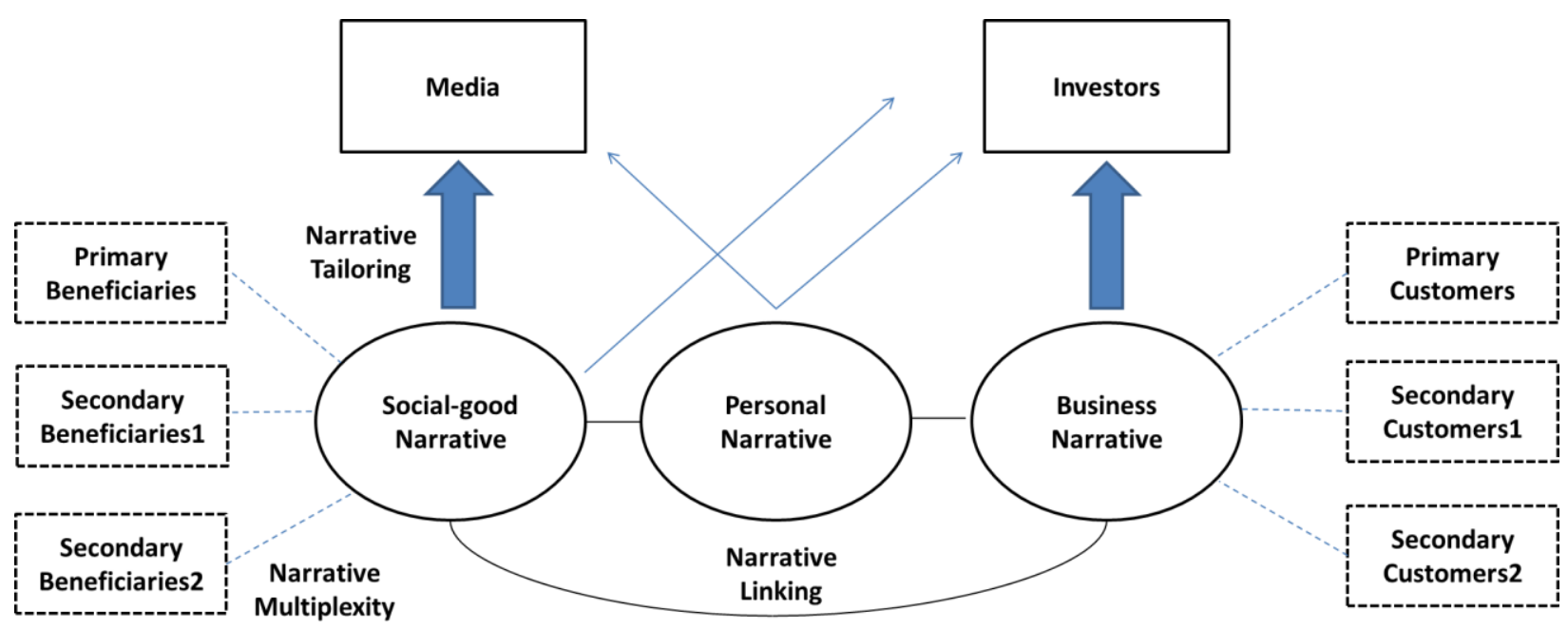


The evolution of funded social enterprise narratives can be compared with that of the unfunded ventures. In particular, there are several differences in their narrative trajectories; each involves a social enterprise getting "stuck" at phase 1 or phase 2. First, the social enterprises that did not make it past phase 1 developed a compelling social narrative but under-invested in the development of other narratives and, particularly, their business narrative. They may have experienced some success generating media attention (because of their compelling social narrative); however, they were generally unsuccessful with investors because with only one narrative to draw upon - their social-good narrative - they could not tailor their communication to investors. Instead, their communication was dominated by their social-good narrative. As described, such narratives can have an incremental influence on investors, but they are not the basis for investors' decisions.

Getting stuck at phase 2 also had an influence on entrepreneurs' ability to secure investment. Unlike the social entrepreneurs that did not make it past phase 1 , these entrepreneurs had a business narrative, although it may not have been fully developed. They did not, however, create as many reinforcing ties between narratives as successful entrepreneurs, nor did they have narratives that allowed for multiple beneficiary and customer groups. Instead they focused on the same beneficiary and customer groups that were the initial target of the venture. As described in the previous chapters, there is evidence that this is not evaluated positively by investors.

Specifically, of the three unfunded cases, Sigma can be classified as not progressing past narrative phase 1 , while Rho and Omega each did not progress past phase 2. More specifically, Sigma focused their efforts on developing their social-good 
narrative, to the exclusion of the other two narrative types. This left them with a semideveloped social-good narrative, a fledging personal narrative, and a non-existent business narrative. Thus they emphasized their social narrative with all stakeholder groups, regardless of their audience's interest. The only narratives that they could attempt to link were personal and social; however, these narratives remained largely independent. Finally, Sigma's narratives still targeted their original customer and beneficiary groups. They had not created communication that was flexible enough to appeal to multiple groups. Given their inability to progress beyond narrative phase 1, Sigma's resource acquisition outcomes were as expected. The venture's developed social-good narrative has been the subject of a significant amount of media attention. Their lack of a business narrative, however, has been associated with the venture remaining unfunded.

In contrast, Rho and Omega could be classified as getting "stuck" at narrative phase 2 - but for different reasons. Rho has a clear social-good narrative (i.e. they communicate a defined social problem, solution, etc.) and a semi-developed (although not exceedingly compelling) business narrative. The least developed of the three narratives is their founders' personal narratives. What is preventing the firm from being classified as "phase 3" is its lack of connections between narrative-types (i.e. its lack of linking) and the lack of multiplexity in its narratives (i.e. its limited number of potential linkages to multiple stakeholder groups). Regarding the former, even though the founders possess the "material" for a compelling personal narrative (e.g. the idea for the venture came as an epiphany after an African mission trip), they do not fully utilize this narrative in communications with the media, nor do they form explicit connections between these 
experiences and their business and social-good narratives. In addition, in their communication, Rho attempts to appeal to narrow customer and beneficiary groups. They do so despite founder statements that their enterprise could be pitched as influencing multiple stakeholder groups.

Omega failed to progress, and arguably failed to get funding, for similar reasons. They had a well-developed social-good narrative and a less-developed business narrative. As described above, the founders decided not to develop a personal narrative. Moreover, founders expressed difficulty in knowing which narrative to employ with different stakeholder groups such as investors and the media (i.e. they had difficulties with narrative tailoring). In addition, although founders described how their enterprise could serve multiple customer groups (e.g. individual consumers, nonprofits, and corporations) they did not create narratives that could simultaneously appeal to each of these groups. Instead, they alternated between focusing entirely on appealing to one group and then the others. The venture's communication did, however, contain some narrative linking. Although there is not a personal narrative to link with the other narrative types, elements of the social and business narratives were combined.

Finally, the fact that three of the eight social enterprises did not reach the third narrative phase begs the question, what causes entrepreneurs to become stuck at a particular phase? Or conversely, what influences entrepreneurs' ability to progress through the three phase? While there are several factors that could arguably affect this process, there is some evidence that entrepreneurs' experiences seeking funding, and particularly their receptiveness to investor feedback, is an important influence. 


\section{What Prevents Entrepreneurs From Getting "Stuck"?}

Investment seeking experiences described by Alpha's CEO are suggestive of how the funding process influenced the evolution of her venture's narratives. For instance, she explains that she first pitched socially-conscious (i.e. "impact") investors, but with little success.

We were pitching socially conscious, high net-worth individuals to begin with. And what we found is they said, "Look you're not a nonprofit; we don't want to touch you.

The "impact" investor class can be reluctant to fund for-profit social enterprises because the investors often operate more like philanthropists than investors and thus would rather apply their money directly to causes (e.g. buying food to feed the homeless; building wells in the developing world). Lack of success with this type of investor forced Alpha to seek funding from more traditional sources, such as angel and VC investment. The CEO describes how the iterative, learning process involved in pitching to investors influenced the evolution of her narratives.

But still it's hard, when it's your baby - to figure out what exactly [investors want to hear]. So, for me, the learning was learning how fundraising works, learning, 'What are they interested in seeing? What numbers do they need to see? How does it need to be positioned?' And then continually getting feedback and feedback and feedback, and practicing and fine-tuning and switching slides out and, 'Which slide is more important? And, I pitched to this group, and how did it work?'

Beta's founder describes similar experiences. First, he explains that the venture's social- good mission initially dominated his communication.

That started as a big piece of our story - that our vision is to contribute $\$ 1$ billion a year to traditional philanthropy. That was front and center of what we do. 
But, the CEO describes how fundraising came with a difficult realization: if he wanted to secure outside investment he would need to shift from his heavy social-good focus towards a business focus, at least when communicating with investors and other business-minded resource providers.

And then we realized that's not what investors are interested in [the social mission]. They like that, but they want to see $150 \mathrm{X}$ on their investment. Our investors want to make money. Our clients want to make money. I'm not gonna sugar-coat it. I want to change the world with this, but I want to make a good living as well. And I think what I've come to realize is that - I've always been the kind of person that I'm like, 'I don't care. I don't want to make billions of dollars. It doesn't really interest me,' but I have to take that approach. I have to count dollars more than I want to.

Beta's founder explains that seeking investment was not enjoyable, but it revealed

to him the importance of tailoring a message to fit an audience.

I hated doing fundraising because it was always talking about money, always talking about money and how much money we're going to make. That's not why I started this, but in the end you have to speak the language of your audience whether it's a potential client or a potential investor, and the language that businesses and organizations want to hear is how they're going to make money.

Moreover, he describes how his personal beliefs made it difficult to transition to more

business-focused communication.

It's a tough thing to do. I can tell you politically I'm borderline socialist, I'm certainly not a capitalist. I've always worked in the Third Sector. So the idea or transition of my whole mentality and my approach in the language that I use to be much more profit-oriented took some soul-searching and took some effort. But, like I said, it's a lot easier to do that if your business model has a clear bottom line that is tied to impact rather than just impact and 'we'll figure out how to monetize this as well'.

Since many social entrepreneurs have backgrounds similar to this founder's (e.g. extensive work experience in the nonprofit, or "third", sector), this is suggestive of why 
so many also struggle with developing a business emphasis and do not progress past narrative phase 1 or 2 .

Narrative Evolution: Investor's Perspectives

It is not just the statements of entrepreneurs which suggest that the investment process helped shape the evolution of successful social enterprise narratives. Investors also describe their influence on this process.

An angel investor that took part in Alpha's seed and Series-A rounds describes how in the early life of the venture the CEO communicated a dominant social-good message.

[Alpha] was originally framed as a social venture. I don't think she [the founder] understood where its trajectory really could be. I think what she knew is that it was a wicked smart idea. I don't think she had any idea how it could be monetized but just had faith in the concept.

The investor explains how feedback from the fundraising process has helped to shape the evolution of the venture's narratives.

[The shift from social-good emphasis to business] that's something that has been a natural response to other investors, to clients, basically to the market. The market provides feedback to her vision, to her pitch. So she's responding to all of the questions people are asking, the questions all of us are asking.

Indeed, a second investor, who also took part in both rounds, explains that fundraising feedback has even led the founder to cease using the label "social venture" because the term suggests that the venture is not a "real business".

I think she stopped saying it was a social venture, honestly. She started off saying it was a social venture, and then she would immediately have to start digging herself out of - like 'no, no, no, it's a real business.'

However, as described in the previous sections, it is important to reiterate that none of the investors suggested entirely abandoning the social-good message. Instead, they suggest 
that entrepreneurs should embed their social mission into a dominant business narrative. For instance, one of Beta's investors, who invested in both seed and Series-A rounds, explains how the venture initially had a strong social-good emphasis, but that the founder's emphasis in communication with investors "has really moved over the last 18 months into a more sophisticated approach of entrenching the social component into consumer transactions [the business side of the venture]." But, as this quotation suggests, moving from a pure social-good emphasis to a more nuanced narrative that combines elements from the social-good narrative with the business narrative, takes time.

\section{Summary}

An important, unaddressed question is, is it necessary for social enterprises to spend time at each of the three narrative phases in order to be successful in acquiring resources? Or, can a social enterprise "skip" to the third phase (i.e. simultaneously develop compelling and interconnected business, social-good, and personal narratives very early in the life of the venture)? Of the five venture's successful in securing external investment, four closely followed the evolutionary trajectory described above, spending time at each of the three phases. Moreover, one could argue that narrative phases 1 and 2 did serve a purpose for these social enterprises. First it seems to have been important for the ventures to start with a strong social narrative because such narratives generate the early resources and support that can help get a new venture off the ground. For instance, several successful entrepreneurs explained how they believed their social-good narratives gave them significant advantage in attracting high quality employees. Indeed, multiple entrepreneurs claimed that their social-good message helped them to attract employees 
that they could not have "afforded" (i.e. they suggested that some employees were willing to take a discount in pay because of their identification with the social venture's cause). Similarly, the social-good narrative also helped entrepreneurs to attract volunteers, which are not common in traditional new ventures. Lastly, beginning with a dominant social-good narrative may signal to some stakeholder groups that the venture is in business for the "right reasons". In other words, it is clear to stakeholders that the social mission is the driving force behind the venture and not something that was merely added on after-the-fact (e.g. as a marketing tool).

Second, it may be important for entrepreneurs to spend time at narrative phase 1 because in this stage the entrepreneur develops an understanding of the problems and needs of their primary beneficiary and customer groups and strong connections to these groups. If entrepreneurs begin with communication targeting multiple beneficiary and customer groups, their connection to any one group may be limited. Moreover, evidence described previously suggests that there is a benefit to having a clear primary customer and primary beneficiary (in addition to have secondary customer and beneficiary groups). A social venture's "primary" groups become an intricate part of their identity and, as prior work would suggest (Martens et al., 2007), this identity can play a role in acquiring resources.

In contrast to arguments suggesting that social entrepreneurs need to pass through each narrative phase to be successful, the one successful social venture that did not follow this narrative trajectory - Gamma - provides conflicting evidence. Unlike the other successful ventures, Gamma began with a dominant business narrative and with 
underdeveloped social and personal narratives. Thus, their narrative emphasis was opposite that of the other successful (and unsuccessful) ventures that started with dominant social narratives and less developed, or nonexistent, business narratives. Over time, Gamma strengthened its personal and social-good narratives and created linkages between these narratives and its business narrative. Moreover, the founder began by using the business narrative with all resource providers, but has since begun to tailor his narrative use (e.g. to emphasize the social narrative with media).

One explanation for Gamma's unique narrative evolution is that it is an artifact of the founder's prior experiences. As described, prior to Gamma, the founder was a serial telecommunications and internet entrepreneur who had previously founded and sold multiple companies. Since Gamma was his first foray into social enterprise, it is likely that he approached the venture like he did any of his other, non-social businesses. Presumably, one of the primary activities in founding those ventures was developing a strong business narrative. Thus, that was also his emphasis when founding Gamma.

It should be noted that although Gamma began with a strong business rather than social-good narrative, it did not circumvent every part of narrative phases 1 and 2 . For instance, once the founder began to develop his social-good narrative, he focused on a single, primary beneficiary group (i.e. feeding the hungry). Only after this group was fully established as a key part of the social enterprise's identity, did the venture begin to branch out to other, related beneficiary groups.

A potential downside to Gamma's approach - i.e. starting with a strong business narrative and then over time developing a social narrative - is that some stakeholder 
groups may question the venture's legitimacy as a social enterprise. That is, stakeholders may question if the venture is truly a social enterprise or if it is just using the "social venture" guise as a way to get media attention, to attract socially-conscious customers, or to differentiate themselves from competitors. Such groups may then be reluctant to promote or partner with the venture, which can influence its ability to acquire other resources.

Finally, although there may be other evolutionary narrative paths that can lead to funding success and failure, seven of the eight firms in this study began in a similar narrative position and set off on the same evolutionary path (although, as described, some social enterprises got "stuck" along the way). Over time, the most successful ventures developed a compelling, complex, and interdependent set of narratives that could be tailored to different audiences and that had potential connections to multiple stakeholder groups. 


\section{Appendix B: \\ The Theory of Narrative}

Preliminary findings from pilot interviews and investigations of practitioner writings, suggest that narrative theory, research on emotion, and work that has examined the two in consort, is likely to be particularly salient for the phenomenon I am proposing to study. At the same time, there is an important theoretical gap in the management literature examining narratives. Specifically, the role of narratives in audiences' emotional (rather than cognitive) responses, has received no attention. However, in the sections that follow I provide detailed reviews of the portions of the narrative literatures that are likely to be drawn upon as I engage in data analysis. Emphasis is placed on the opportunities that remain unexplored in these literatures and, particularly, on research that may be applicable to understanding resource acquisition.

\section{The "Narrative Turn" in Organization Studies}

The study of narratives is not a recently established academic endeavor (Connelly \& Clandinin, 1990). Indeed, the first "narrative theorist" is often identified as Aristotle, who provides a detailed analysis of narrative structure in Poetics. However, the "discursive turn" in philosophy and the social sciences (e.g. Harre, 2008), which emphasizes the power of language and rhetoric in shaping the social construction of reality, has resulted in growing attention to the influence of narratives. Indeed, disciplines as disparate as law and criminal justice (e.g. Maynard, 1988), medicine (e.g. Greenhalgh, 1999), public health (e.g. Greene and Brinn, 2003), and agriculture (e.g. Morgan, Cole, Struttmann, \& Piercy, 2002) have found that narratives and non-narratives have a 
dissimilar influence on factors such as decision making, persuasion, and evaluation. Moreover, this increased interest in the narrative form has produced several statements about the elemental importance of stories. For instance, narratives have been described as the "main mode of human knowledge" (Bruner, 1986: 14), "our primary means of communication" (Fisher, 1985; Czarniawski, 1998), and "the central function...of the human mind" (Jameson, 1981: 123).

Other theorists have been even more forceful about narrative's importance. French philosopher Jean-Francois Lyotard posits that stories are the "quintessential form of customary knowledge" (1984: 19) and Schank and Abelson (1995: 2) insist that "all of our knowledge is contained in stories and the mechanisms to construct and retrieve them" (p. 2). The strength of these assertions suggests that there is a primeval quality to narratives and the role they play in human existence. Indeed, the use of stories is said to be so central to being human, and in particular, so critical to the preservation and transmission of human culture, that it has been argued that a more accurate name for our species is homo narrans, that is, "narrative human" (Fisher, 1985; Niles, 1999).

Indeed, narratives can manifest in any form that discourse can take (Chatman, 1980). They can be conveyed through a text, a series of images, or through oral discourse. They also exist in virtually every domain of discourse, including entertainment (Moyer-Guse, 2008), advertising (Chang, 2009), political rhetoric (Bridgman \& Barry, 2002), and science communication (McComas \& Shanahan, 1999). Moreover, the 
"genus" of narratives is comprised of several types; a non-exhaustive list includes myths, parables, folk-tales, personal testimonies, scenarios, and anecdotes ${ }^{19}$.

Statements explicating narrative's importance, the increased focus on narratives in several disciplines, and the prevalence of stories in all forms of communication, begs the question: why are narratives so influential? Several factors (described in detail in the next section) explain this influence and are suggestive of the role narratives may play in resource acquisition.

Moreover, growing attention to narratives has spurred management researchers to consider the role of stories in the organizational context. Although narratives have yet to receive as much attention in management as in other fields, beginning in the 1980s and continuing to the present, there has been a "narrative turn" of sorts in the study of organizations (Boje, 2005). For instance, narratives' role in micro-phenomena, such as employee-level identity construction and sensemaking, as well as more macro-oriented phenomena, such as organizational change and legitimation, has been examined. In the sections that follow, I first provide a brief review of the main tenets of narrative theory, with particular emphasis placed on answering, "What is a narrative?" I then summarize the general findings about the influence of narratives on decision making and evaluation. This section is guided by the question, "Why are narratives influential?" Next, I review specific findings from non-management literatures on the dissimilar influence of narratives and non-narratives. Finally, I review several streams of research in the

\footnotetext{
${ }^{19}$ All of these types are contrasted with non-narrative forms of discourse, such as lists, chronicles, statistical estimations, and technical arguments (Wit et al., 2008). The fundamental difference between the two forms is attributable to the definition of narrative, which is discussed at length below.
} 
management literature that have increasingly emphasized the importance of narratives and that may be relevant for understanding the resource acquisition attempts of social entrepreneurs.

\section{Narrative Theory: An Introduction}

A "narrative" is defined as a collection of events (e.g. actions, experiences) arranged in a temporal sequence and containing a causal explanation (Onega \& Landa, 1999). According to this definition, a narrative must possess two, co-occurring elements: temporality and a causal explanation. Temporality means that events are arranged in a coherent sequence and that the order in which they occur matters (Hoshmand, 2005). The causal component, which is commonly referred to as a "plot" (Ellis, 2005), is the theme that makes clear the relationships between events. A plot structures the collection of events, so that each individual action or experience contributes to the creation of the overarching narrative. Together, temporality and plot provide the "intelligible whole [or framework] that governs the succession of events" (Ricoeur, 1981: 167).

It is important to note that temporality does not imply linearity (Wentzel, Tomczak, Herrmann, 2010). The events of a story must be sequentially connected and must cohere in terms of their antecedents and outcomes (Hoshmand, 2005); but they do not have to follow a linear temporal progression. For instance, the conclusion can be presented first and then followed by the events that brought it about (Polyorat, Alden, \& Kim, 2007). Similarly, causal explanation (plot) and causality are not the same. For instance, for two events, A and B, causality represents "A causes B". In contrast, causal explanation is represented by "A causes B, because..." In other words, a narrative is 
teleological; it provides reasons not just causes (Rudd, 2007). However, the "because" of a narrative can be either explicit or implicit.

Defining narrative as a collection of events possessing temporality and plot is arguably a minimal definition of the concept (Herman, 2007). Narrative theorists have expanded on several components of this definition and, particularly, on what must be contained in the "collection of events" and the plot. For instance, Burke (1969) argues that the events must possess: an actor, an action, a goal, a scene, and an instrument. Other definitions require that the narrative include specific types of characters (e.g. a protagonist and an antagonist) and that the plot contain specific elements, such as a disruption of the status quo, a transformation in one of the main characters, or other literary devices (cf. Altman, 2008). Overall, there is considerable debate about the "correct" definition of the narrative form (Riessman, 1994). However, while the literature is replete with lists describing the elements that communication must contain to be considered a story, there is little debate about whether temporality and plot are necessary elements; in fact, they are recognized by virtually all narrative theorists as foundational elements. Thus, for the purposes of this study, a definition focusing on the most widely agreed upon, and least contested, elements, is adopted.

An often-used example from the narrative theory literature illustrates this definition and highlights the distinction between narratives and non-narratives. The following sentences, "The King died. The Queen died" are two, non-narrative, statements of fact (Forster, 1955/1985). They possess neither temporality (i.e. it is unclear which of the events occurred first) nor a causal explanation (i.e. it is unclear if the events are 
related). The statements become a chronicle, but remain non-narrative, if they are written as, "The King died and then the Queen died." This statement possesses temporality, but still lacks a causal explanation. The chronicle becomes a narrative (albeit a basic one) when it includes, "The King died and then the Queen died out of grief', because a basic plot now unites the two, temporally ordered events.

There is an additional distinction between narratives and non-narratives, which is not based on the possession (or lack) of structural elements (i.e. temporality and plot structure). Non-narratives, such as technical arguments, are judged based primarily on criteria such as logicalness, consistency, and their truth or falsity. Narratives, however, are evaluated based on two very different criteria: novelty and believability (Heil \& Whittaker, 2007). A narrative only resonates with its intended audience if it is evaluated as both novel and believable. Specifically, narratives lacking novelty, or that are not sufficiently unusual, will be viewed as mundane and, thus, uninteresting. Similarly, narratives that are not believable (i.e. are too unfamiliar) will lack the credibility audiences require. However, novelty and believability are not independent. In fact, the two criteria form a dialectic (Barry \& Elmes, 1997). Narratives that are extremely believable often lack novelty, whereas extremely novel narratives are often not believable (Starkey \& Crane, 2003). In other words, a narrative must both reaffirm and renew its audience's understanding of the world (Bruner, 1990). Authors of effective narratives must balance this tension between novelty and believability. 


\section{Narratives, Decision Making, and Evaluation}

Several factors are argued to explain why narratives are so influential. In particular, when compared to other forms of communication, stories are more able to elicit attention, to influence understanding and sensemaking, to be memorable, and to be easily transmitted between individuals. Each of these factors will be examined in turn ${ }^{20}$.

\section{Attention}

Stories possess a unique ability to attract and hold attention (Green, 2008; Nisbett \& Ross, 1980). This is attributable to several characteristics of narrative communication. First, stories are often more concrete than other forms of communication (Baesler \& Burgoon, 1994). Concreteness is defined as the extent to which communication can be experienced directly by the senses (Paivio, Yuille, Madigan, 1968). It is a function of the ease with which mental images can be created about communication content (i.e. its imagability). Narratives are often highly imageable (Sadoski, Goetz, \& Fritz, 1993) thus making them more likely to be concrete than other forms of communication.

There is also a greater likelihood of narratives possessing a related characteristic: proximateness. Proximateness is the extent that communication is perceived as close to the audience in a "sensory, temporal, or spatial way" (Nisbett \& Ross, 1980). In other words, communication that is proximate is perceived as "near", or relevant to, an audience in some way. The concreteness of stories, coupled with their ability to personalize content, makes narratives generally more proximate than other, more abstract forms of communication (Baesler \& Burgoon, 1994).

In general, communication that is more concrete and proximate is more accessible and understandable than communication without these characteristics. In turn, the easier

\footnotetext{
${ }^{20}$ The findings presented below come, primarily, from lab-based experimental studies in disciplines across the social sciences. Findings from studies that emphasize a particular social context are discussed in the section that follows.
} 
it is for individuals to access a piece of information, the more likely it is that the information will be selected for consideration (Kazoleas, 1993). In contrast, nonnarratives, which are less likely to possess concreteness or proximateness, are not as accessible and, thus, not as likely to attract attention (Kazoleas, 1993).

Narratives also influence attention through their ability to present information in an interesting way (Schank \& Abelson, 1995; Schank \& Berman, 2002). Information perceived as interesting is more likely to be granted attention (Hidi \& Baird, 1986) Narratives are often perceived as more interesting than non-narratives because they are particularly effective at both introducing novel information and defamiliarizing existing information (Oatley, 2002). Also, a narrative is often rich in details, and particularly image-invoking details, which increases its interestingness (Hidi, Baird, Hildyard, 1982).

Lastly, stories attract attention by evoking several states that are related to the temporal structure of communication. These states include suspense, curiosity, and surprise (Alwitt, 2002). In particular, structural affect theory (Brewer \& Lichtenstein, 1981) suggests that suspense is evoked by postponing the story's outcome, curiosity is evoked by placing the outcome before the preceding events, and surprise is evoked by including an event unexpected by the narrative's audience (Hoeken \& van Vliet, 2000). All three states are associated with greater interest and attention (Graeser, Golding, \& Long, 1996)

Overall, if individuals are faced with a "sea" of available information, or even the choice between narrative and non-narrative forms of information, then communication that possesses the characteristics associated with stories, such as concreteness and interestingness, is generally more likely to be noticed, to be given attention, and ultimately, to be selected for consideration. 


\section{Sensemaking}

After narrative communication becomes the subject of attention, an attempt is made to understand the information contained in a story and to integrate it into an individual's exiting schema, or mental model (Brewer, 1984). During this process, which can be referred to as sensemaking (Weick, 1979), there is interplay between how individuals process narratives and how they come to understand the world around them. Specifically, stories help to give events, actions, and objects meaning (Czarniawska, 1997) and serve to organize sensemaking (Weick, 1995). Indeed, it is argued that "the ultimate lack of sense is when [one] cannot produce a narrative to go with a situation" (Wallemacq \& Sims, 1998: 121). Narratives aid sensemaking by both connecting and segmenting experiences, which allows for the prediction of future experiences.

First, stories help individuals make connections between experiences. Indeed, it is argued that narratives serve as the lens through which the apparently independent and disconnected elements of existence are seen as related parts of a whole." (Polkinghorne, 1988: 36). Narratives are able to connect, or "pattern" (Pentland, 1999), experiences by imbuing collections of events with a plot (a process referred to as emplottment; Ricoeur, 1981). As previously described, a plot is an overarching theme that, like a common thread, ties together individual events into the sequences that comprise a narrative. A plot integrates a complex and loosely coupled bundle of events and makes it a causally coherent whole. In this way, sensemaking can be viewed as an attempt to integrate a new event (or events) into a plot. Doing so makes the event understandable in relation to what 
has already happened. Thus stories connect experiences in a way that leads to sensemaking (Harrasser, 2002) ${ }^{21}$.

In addition to connecting events by integrating them under a unified theme, narratives also contribute to sensemaking by segmenting - or "chunking" (Herman, 2009) - events and experiences (Wigren, 1994). Individuals are faced with a steady stream of experiences, which can make it difficult to distinguish what experiences are relevant to a given decision or course of action. Narratives reduce this experiential "overload" (Edmunds \& Morris, 2000) by segmenting the stream of experiences into units that form a discrete and bounded whole (Minsky, 1975; Herman, 2003). Indeed, stories can "selectively distill a complex jumble of otherwise ambiguous and contradictory activities, pronouncements, and impressions into a simplified and relatively coherent portrait" (Ashforth \& Humphrey, 1997: 53). Thus, they aid sensemaking by making it clear what experiences or events need to be made sense of and which ones can be ignored or discarded.

\section{Memorability and Prediction}

After an individual has granted attention to a narrative and integrated it into an existing schema, a story can further influence cognition through its availability in memory (McCabe \& Peterson, 1990). Compared to other forms of communication, narratives are generally more likely to come to mind; moreover, they also come to mind faster and with greater ease (Black \& Bern, 1981). Stories are recalled with greater

\footnotetext{
${ }^{21}$ In sensemaking, individuals either use plots provided to them or form their own to understand how a sequence of events is related; however, if an individual is faced with an environment where sensemaking is challenging, for example one characterized by uncertainty and ambiguity (Duncan, 1972), then an existing narrative, which contains a prepackaged explanation for how events fit together, can be perceived as appealing.
} 
frequency, ease, and speed because of how they are incorporated into individuals' schema and, specifically, because of the way they influence the process of indexing.

As information (narrative and non-narrative) is incorporated into an individual's schema it is indexed. Indexing involves information being attached to, or bundled with, other elements of an individual's existing knowledge base (Fiske \& Linville, 1980). Narrative communication is more effectively indexed than other forms of communication for at least two reasons. First, stories often contain a multitude of ties (or "links") to the existing elements of an individual's schema. These ties include locations, attitudes, beliefs, quandaries, decisions, and conclusions (Peterson, 1999). As the number of ties increases, there are more places that information can be indexed, which means that the information will be more salient in memory. Second, narratives not only possess a greater quantity of ties, but these ties are often stronger than those contained in other forms of communication (Wit et al., 2008). Specifically, stories often produce an emotional response in audiences ${ }^{22}$. These responses create a more detailed representation in memory (what Wit et al., 2008 refers to as an elaborate "memory trace"). When such representations are indexed, they are strongly tied to individuals' existing schemas, which improves recallability.

Finally, a narrative's memorability allows it to serve as the basis for understanding and predicting new experiences, and, hence, for future sensemaking (Herman, 2003). As explained, one of the reasons narratives are able to infuse events with meaning is because they can be used to order events. Ordering is related to

\footnotetext{
${ }^{22}$ The link between narratives and emotional responses is discussed at length in the next section.
} 
prediction because, when a collection of events are unordered and disjointed, an individual has little basis for making predictions about what future events may follow from the ones in the collection. In contrast, in ordering events and tying them together causally, a story represents the "conceptual model" (Pentland, 1999: 711) for how the process or relationship that is described works. This model can be used for prediction.

Moreover, narratives can increase predictive ability by drawing on individuals' existing knowledge. Specifically, a given story will lead an individual to recall prior knowledge of a similar sequence of events or experiences (Ricoeur, 1984; Schank \& Abelson, 1995). This knowledge is often contained in a previous narrative, which can be used as a source of understanding and prediction. Indeed, individuals not only make sense of their world in narrative terms (Scott \& Lyman, 1968; Weick, 1995), but they also enact (and re-enact) narratives that they have previously heard and that are consistent with their expectations, values, and prior narratives (Czarniawska, 1997). Thus, narratives become "like ruts in the road that people follow and thereby re-create." (Pentland, 1999: 712).

\section{Efficiency of Communication}

In addition to their influence on attention, sensemaking, memorability, and prediction, narratives also influence cognition through their effectiveness as a mode of communication. Specifically, stories are a particularly flexible and efficient means of transmitting information between individuals and preserving content over time.

First, narratives possess a "plasticity and interpretive flexibility" (Rhodes \& Brown, 2005: 174) that allows the same stories to be told multiple times and in multiple 
situations. Indeed, narratives are malleable in that that they can be applied and adapted to a diverse set of situations and to circumstances beyond the ones they were originally produced to describe (Brockmier \& Harre, 1997). Moreover, narratives are flexible in that a single story can incorporate multiple perspectives across time (Fiese, Sameroff, Grotevant, Wamboldt, Dickstein, \& Fravel, 1999; McHale, 2005). In contrast, nonnarrative forms of information (e.g. statistics) are often more closely tied to a specific set of circumstances and to a specific temporal moment and are, thus, less flexible.

Narratives are also efficient means of communication. Their efficiency is attributable to the fact that, at a young age, humans become adept at processing and making sense of narrative communication (Bamberg, 1997). Specifically, early in cognitive development "story-schema" (i.e. knowledge structures used for the comprehension and encoding of stories) are formed (Yekovich and Thorndyke, 1981). This specific type of schema is developed through repeated exposure to narratives (Cortazzi, 1993).

Story-schema allow stories to communicate a large amount of information using very few words (Kopfman, Smith, Yun, \& Hodges, 1998). This information can be transmitted rapidly throughout a communicating population (Forster et al., 1999). Further, because these schema are widely shared cognitive structures, narratives are broadly transferable. Moreover, narratives package information in a form that can easily be preserved and passed on to future "generations" of users (Malesh, 2009). Thus, stories stand to have a potent influence on cognition because they allow individuals to 
communicate about events they have not necessarily experienced first-hand; that is, the telling of narratives allows events to be experienced vicariously (Wilkins, 1984).

Finally, narratives aid communication by improving individuals' ability to describe events. As reviewed above, stories are particularly effective at representing the relationships between events in a complex process (Pentland, 1999). However, in addition to providing events with temporality and plot, narratives are also a description for how the process that the story describes works (Bal, 1985). This property allows narratives to be used to communicate about the process contained in the story. Moreover, through conversation, an individual can compare and contrast their understanding (i.e. their narrative) with the narratives of others. Taken together, by serving as a compact description of a process or collection of events, narratives make their content more transferrable, which in turn can influence an individuals' descriptive power and, ultimately, their understanding.

In general, narratives' role in attention, sensemaking, memory, and communication represent the underlying mechanisms through which narratives influence decision making, evaluation, and, potentially, resource acquisition. However, studies that focus on understanding these mechanisms do not address how individuals use narratives to influence others. In order to shed light on this process, it is necessary to look at studies examining narratives in specific social contexts.

\section{Narratives in Non-Management Contexts}

There are many studies that examine the differential influence of narrative and

non-narrative information under experimental conditions that do not emphasize a 
particular social setting or interaction (e.g. Sadoski, Goetz, \& Fritz, 1993). However, in addition to this work, there are several streams of research that seek to understand the effect of narrative information in more specific contexts ${ }^{23}$.

For instance, findings suggests that information in story form can have a stronger influence than non-narratives on: jurors' verdicts (Pennington \& Hastie, 1993), individuals' decisions regarding medical treatments and health-related activities (such as vaccinations and organ donation; Kopfman et al., 1998; Greene \& Brinn, 2003), farmers’ attitudes towards agricultural safety messages (Morgan et al., 2002), and even individuals' decisions about the risk associated with toxic substances (Golding et al., 1992). The differential effect of narrative and non-narrative information in these contexts is attributed to several specific qualities of stories that are less likely to be qualities of non-narrative information, including concreteness (Enkin \& Jadad, 1998), intuitiveness (Kopfman et al., 1998), and emotionality (Baesler \& Burgoon, 1994).

In the business context, there is a stream of research in accounting that examines whether analyst decisions differ based on if they use financial information communicated as a narrative or a non-narrative. For instance, Sedor (2002) finds that analysts make more optimistic two-year-ahead earnings forecasts when provided information about a manager's future plans presented as a narrative than when provided the same information presented in list form. Building on this finding, there are also studies showing that narrative-induced optimism does not negatively influence predictive ability. In fact, Smith and Taffler (1995) find that participants receiving narrative accounting information

\footnotetext{
${ }^{23}$ In some cases, there are dozens of studies in these research streams, so attention will only be paid to representative studies that inform the research questions of this study.
} 
are better able to discriminate between failed and non-failed companies than participants receiving financial information. Finally, there is evidence that differences in the thematic structure of annual report narratives can influence the readability and understandability of the documents (Clatworthy \& Jones, 2001; 2003; 2006; Smith \& Taffler, 2000).

In addition to this research, there are several, inter-related literatures examining the influence of narratives in marketing, advertising, and consumer research, which are larger and more developed than research in the accounting literature. In general, these studies are more grounded in psychology and more focused on understanding the specific mechanisms that make stories an influential source of information, than work in accounting.

For instance, several studies by Escalas (e.g. Escalas, 2004a; Escalas, 2004b; Escalas, 2007) examine the role of stories in forming connections between consumers and brands. Escalas (2004a) argues that narratives create (and enhance) self-brand connections because ads that tell a story create a link between the brand and the individual. This connection is created when consumers incorporate the stories into existing narratives (and story-schema) in their memory. Escalas (2004b) expands on the mechanisms underlying the relationship between narrative ads and consumers' connections to brands. It is argued that stories persuade consumers through mental simulation and, specifically, through the process of transportation (Gerrig, 1993; Green \& Brock, 2000) $)^{24}$. Moreover, Escalas finds that narrative transportation produces strong affective responses in consumers and low levels of critical thought, which, in turn, affect

\footnotetext{
${ }^{24}$ Research examining narrative transportation is examined in greater detail in the Narrative and Emotion section.
} 
consumer attitudes and brand evaluations. Finally, in an additional study on narrative transportation, Escalas (2007) finds that for consumers transported by narrative advertisements, the persuasiveness of an ad is not affected by argument strength. Indeed, ads that transport are persuasive regardless of whether they contain strong or weak arguments.

In a related study of fictional versus factual message strategies in print ads, Polyorat, Alden \& Kim (2007) find that fictional stories result in more favorable product evaluations than fact-based messages. In addition, they find that message involvement mediates the relationship between message strategy (fictional-narrative vs. factual) and evaluation. Specifically, narrative ads result in greater message involvement. In turn, greater involvement is associated with more favorable evaluations. Finally, in two related studies, Mattila (2000; 2002) examines whether audience expertise influences the relative effectiveness of narrative-based messages. She finds that consumers with relatively little familiarity with a product category (i.e. low expertise) prefer appeals based on narratives to appeals based on a list of product attributes (Mattila, 2000). The role of the consumer's mood in moderating this relationship is also examined. Mattila (2002) finds that the relative advantage of narrative ads is magnified when the novice consumer is in a happy rather than sad mood while processing the ad.

\section{Narratives and the Management Literature}

Increased attention to narrative communication in other disciplines has inspired management scholars to consider the role of stories in several established organizational literatures. Most of these studies fall within four theoretical areas: sensemaking, identity 
construction, organizational change, and power and legitimacy. Each of these research streams is examined in turn.

Narratives and Sensemaking

One of the most consistent findings in the non-management, narratives literature is that there is a strong interrelationship between narratives and human cognition (e.g. Schank \& Abelson, 1995; Cortazzi, 1993). As discussed, stories play a role in several facets of cognition. They can influence what information is granted attention, how it is processed, what is remembered, and how it is passed between individuals. The link between narratives and thought, and in particular the link between narratives and information processing, has also been examined in the management context and, specifically, in the organizational sensemaking literature.

Narratives help to give events, actions, and objects meaning, which directly influences and organizes sensemaking (Weick, 1995). Indeed, narratives have been identified as one of the key interpretive tools in both individual and collective sensemaking (Boje, 1991). For instance, Weick (1995) has argued that the activities necessary to produce a narrative, such as gathering strands of experience into a plot, provide a perfect frame for sensemaking.

In addition to the general role played by narratives in sensemaking, Weick (1995) also identifies several, more specific functions of narratives. First, stories aid comprehension by integrating that which is known about an event with that which is conjectural. Second, stories suggest a causal order for events that may originally be perceived as unrelated. Third, stories enable individuals to talk about absent things and to 
connect them with things in the present. Fourth, stories act as mnemonics enabling individuals to reconstruct earlier events. Fifth, stories can be used to guide action before routines are invoked and can supplement routines after they are formulated. Sixth, stories enable individuals to build a database of experience, which can be used to infer how things work. Finally, stories transmit and reinforce culture by conveying values and meanings (Weick, 1995: 129).

Even though Weick emphasizes the importance of stories in sensemaking, narratives are just one piece - albeit an important one - in his larger theories of sensemaking and cognition. But, there are several other studies in the management literature, which are more narrative-focused in their examination of the role of stories in sensemaking. These studies can be divided into three (interrelated) groups based on the type of sensemaking examined: sensemaking in complex environments, sensemaking during organizational change, or sensemaking of individual work experience.

First, there is evidence that narratives are used to aid sensemaking in complex and ambiguous environments. For instance, in a study of Federal Reserve policy-makers, Abolafia (2010) finds that narratives are crucial in allowing policy-makers to make sense of their complex environment while at the same time acting consistently with the institutionalized structure of their organization. Specifically, the author finds that policy makers engage in a three-stage sensemaking process comprised of abduction, plotting, and selective retention. In abduction decision makers compare culturally approved narratives to their current conditions in order to establish what facts and events deserve attention. In plotting, the facts and events are reordered into a plausible story. Finally, in 
selective retention, policy makers engage in collective negotiation in order to make a choice that fits with the emerging narrative. This narrative-driven process helps decision makers to navigate a complex economic and political environment.

In addition to helping organizational actors make sense of turbulent external environments, narratives are also used to improve sensemaking during organizational change (e.g. Dunford \& Jones, 2000; Stevenson \& Greenberg, 1998; Skoldberg, 1994). For instance, in an inductive study of a Fortune 500 firm implementing a significant change, Sonenshein (2010) finds that managers tell ambiguous narratives that emphasize how the organization is changing and how it is staying the same. Ambiguous narratives, which feature both stability and progressiveness (i.e. change) allow managers to "freeze" and "unfreeze" the meanings employees attribute to the change. Moreover, employees use the narratives (often embellishing them), in order to make sense of their response to the change. Specifically, employees adapt narratives to align with three types of responses: resistance, championing, or acceptance. In each response, narratives aid employees in understanding the change.

Finally, stories are used not only to make sense of an organization's external environment and to understand large-scale organizational changes but also to understand micro-level work experiences and how they relate to the experiences of others, the organization, and the environment (e.g. Bryant \& Cox, 2004). For instance, Shipp \& Jansen (2011) develop a theory of person-environment fit (Caplan \& Harrison, 1993) that incorporates both temporal and thematic components (i.e. the two defining characteristics of narrative). Specifically, they argue that employees craft and continuously update "fit 
narratives", which are used to make sense of their place in the organization. The narratives influence person-environment fit by linking retrospective, current, and anticipated perceptions of fit by a common theme (i.e. plot), thus allowing individuals to make sense of their past, present, and future role in their organization.

\section{Narratives and Identity}

Work examining the role of stories in sensemaking is closely related to a second group of studies examining the connection between narratives and identity. This research is built on foundational work by MacIntyre (1984) and Bruner (1991) who argued that through the enacting of narratives individuals create and understand their identities. Like the fit narratives described by Shipp and Jansen (2011), the creation of identity narratives - or "life" narratives (Josselson \& Lieblich, 1993) - help individuals to link the events and actions of their past, present, and future (McAdams, Josselson, Lieblich, 2006).

Ibarra and Barbulescu (2010), for instance, argue that individuals engage in "narrative identity work" in order to bridge gaps that arise in social interaction. More specifically, they argue that during work-role transitions individuals draw on their existing repertoire of stories to reconstruct their identities. Reconstruction consists of using feedback from social interactions to update one's portfolio of existing narratives. When these narratives are coherent, they become the basis for an individual's new identity. The identity then acts as a lens for making sense of the employee's new work role.

Combining both individual- and team-level analysis, Brown, Stacey, and Nandhakumar (2008) examined identity and sensemaking in members of a game design 
team. They find that group sensemaking occurs through individual-level attempts at identity construction. Identity construction, in turn, is based on the narratives actors tell about their work and selves, which they communicate to others in the group. Discrepancies in the sensemaking of group members (i.e. different interpretations of common experiences) are attributed to two characteristics of the narratives members tell, impression management and egotism. The authors conclude that factors that influence identity construction (such as self-enhancement and self-consistency) also influence the stories told by group members. When group narratives are not in agreement it leads to discrepancies in sensemaking.

In addition to influencing identity construction in individuals and teams, there is evidence that narratives also play a role in the formation of organizational identities (Brown, 2006). For instance, in a study of a UK-based tourism firm, Brown, Humphreys, and Gurney (2005) find that a firm's collective identity is a "narrative accomplishment", that is, it is constructed from the narratives told by the organization's members. However, similar to the findings of Brown et al. (2008), such stories are not always consistent. Within the same firm, the authors identify three different types of narratives related to the organization's identity: "utilitarian", "normative", and "hedonic". They also document dissenting narratives. Moreover, they find that change in the organization is dependent on individuals' understanding and sharing of these narratives.

In a related study of a UK-based institution of higher education, Humphrey and Brown (2002) again find that the process of organizational identification is constituted by the personal and shared narratives of the members of the organization. Moreover, because 
of their privileged hierarchical position, senior managers are particularly powerful contributors to the narratives shaping organizational identity. The authors also find that senior managers make deliberate efforts to control the processes of identity formation and member identification. Specifically, they seek to mold and to manipulate identity narratives, and to reduce their plurality, in order to legitimate certain organizational actions.

Narratives, Legitimacy, and Power

Humphrey and Brown's (2002) findings illustrate that narratives are not merely tools for creating meaning and aiding sensemaking. Rather, narratives can also be discursive devices used to privilege some voices, and some meanings, over others (Boje, 1991; Boje, 1995). This alternative use of narratives has been examined in several streams of research. First, as Golant and Sillince (2007: 1151) argue, narrative forms of communication are particularly involved in the "emergence and maintenance" of organizational legitimacy. In a study of the founding of an HIV/AIDS organization, they find that managers seeking acceptance for organizational events establish the legitimacy of the events by authoring narratives that support them. Specifically, they find that the construction of organizational legitimacy is dependent on two factors: the persuasiveness of organizational storytelling and the narrative's ability make its content taken-forgranted.

Narratives are particularly well-suited for creating taken-for-grantedness. That is, they can make an activity so accepted that "for things to be otherwise is literally unthinkable" (Zucker, 1983; 23). Stories influence taken-for-grantedness by influencing 
the schemas - or sensemaking structures - individuals use to interpret events (Herman, Jahn, \& Ryan, 2005). Taken-for-grantedness becomes a foundation of legitimacy because if individuals cannot even imagine an action or activity being different than it is, then it is difficult for them to consider it anything but appropriate. So, by shaping individuals' frameworks for reasoning (Suddaby \& Greenwood, 2005), narratives can determine how individuals "see" organizational actions, thus making them more likely to be accepted without question.

Leonardi and Jackson (2004) explore this issue in a study of two high-technology and telecommunications mergers. They examine how organizational leaders strategically adopt certain narratives to engage in image management and to produce an appealing picture of the company for various stakeholders. They find that leaders use a narrative of technological determinism to invoke the "inevitability" of technological. Also, rather than take ownership of the change, managers use this story to claim that the organizational changes are inevitable. The narrative is also used to eliminate alternative explanations for the organizational change.

The use of a narrative to suppress competing narratives is an example of "discursive closure" (Deetz, 1992), which is broadly defined as the use of communication to privilege certain meanings while suppressing, or "closing off", alternative interpretations of events (Deetz, 1992). A key to discursive closure is that it is difficult to notice and virtually taken-for-granted. Narratives are particularly effective at this because by their very structure they "privilege some conceptual systems" and some explanations for events while excluding others (Leonardi and Jackson, 2004: 616). For instance, a 
dominant organizational narrative about why an organization is engaging in an action can mask alternative narratives and can, in a sense, crowd out the less dominant narratives created by individuals (Martin et al., 1983). The result is that the "official" organizational narrative of why an action is occurring becomes legitimized because other narratives do not have the chance to contest the story and to compete for legitimacy.

In addition to their role in legitimizing organizational actions, narratives can also be used as a political tool and as a way to garner power (Brown, 1998). In fact it is argued that narratives are "one of the principal symbolic forms through which organizational ideology and power structure are both expressed and constituted" (Mumby, 1987: 114). For instance, in a study of a major IT implementation in a UK hospital, Brown (1998) examines how groups involved in the change sought to make sense of events in a way that legitimized their actions and protected their interests. He finds that groups use narratives in a political manner to preserve and enhance their interests. Specifically, narratives are used to undermine the IT implementation, which are viewed as a system of technical surveillance designed to routinize and to formalize their work. In subverting the IT system (and the organization's official narrative), employees are able to maintain their task discretion and functional autonomy. Therefore, in this setting, narratives not only play a role in the social construction of technology but also serve as both a hegemonic and emancipatory force.

\section{Narratives and Affect}

As the reviewed studies demonstrate, narratives impact decision making, judgment, and evaluation through processes such as legitimation, sensemaking, and 
learning. These processes are decidedly cognitive. But, while most of the work in the social sciences, and virtually all work in management, has focused on narrative's role in cognition, cognition is not the only pathway through which stories influence individuals. Indeed, affect also plays a critical role in both understanding narratives and in guiding the cognitive processes involved in the comprehension of stories (Oatley, 1999). However, while narrative's role in cognition is increasingly clear, its ability to influence affect and, specifically to persuade through affect, is not understood (Pence, 2004).

The relative lack of attention to the interrelationship between narratives and affect is surprising for at least three reasons. First, in ignoring the interplay between narratives and affect, prior research has underemphasized one of the two primary ways in which human beings come to understand new events and actions. More specifically, dualprocess models suggest that people make sense of reality in two fundamentally different ways (Kahneman \& Frederick, 2002; Slovic et al., 2004). Analytical processing is grounded in deliberate cognition and is reason-oriented, logical, and abstract (Epstein, 1994; Slovic et al., 2004). In contrast, experiential processing is intuitive, automatic, and concrete. The latter type of processing is heavily dependent on affect because it relies on "subtle feeling of which people are often unaware" (Epstein, 1994: 716). Experiential processing is often referred to as "narrative" processing (e.g. Escalas, 2007) because when individuals respond to a new event experientially they automatically search their memory for a narrative containing a related event. This related event is emotionally charged and influences how the individual responds to the new event (Epstein \& Pacini, 1999). Even though analytical and experiential processing are both important for decision making and evaluation (Slovic et al., 2004), the preponderance of research has focused on the cognitive side of dual-processing rather than on affective processing and its link to narratives. 
Similarly, by not examining the relationship between affect and narratives, prior work has underemphasized one of the two ways that individuals process narratives. When individuals are faced with a narrative they often respond cognitively using schemas, prototypes, codes, and scripts (Oatley, 1999). But, when these structures are inadequate or in conflict, it creates uncertainty. Individuals respond to this uncertainty by relying on affective responses. Specifically, in uncertain situations a common response is for individuals to focus on the emotional significance of a story and then, when that is established, to allow emotion to guide the choice of an appropriate schema to aid in understanding (Miall, 1986; Oatley, 1999). However, affect's role in this process has received little analysis.

Finally, the agents of narratives - the characters - are often other individuals (or the self). When we interact with individuals affect plays a central role in helping us to understand their actions (e.g. Francis, 1994). In the same way, individuals rely on affect to understand the actions and experiences of the characters of a narrative (Oatley, 1999). As will be described, stories that contain characters that invoke a strong affective response in audiences can be particularly persuasive (Green et al., 2004). However, few studies have attempted to understand this method of persuasion.

In the sections that follow, a brief overview of the research examining the role of affect in persuasion is provided ${ }^{25}$. This is followed by a review of the literature examining how narratives can influence audiences' affective responses. The findings in these literatures are suggestive of the ways that entrepreneurs may use narratives, and leverage stakeholder emotions, in order to acquire resources.

\section{Affect and Emotion}

\footnotetext{
25 The "affect" and "affect and decision making" literatures are vast. So the review of these literatures will be kept brief and will focus only on the elements of the research relevant to understanding the role of narratives and affect in evaluation and resource acquisition.
} 
Generalized affect is an overarching construct that includes a broad range of feelings such as emotion, mood, and dispositional affect (Arnold, 1960; Park, Sims, \& Motowidlo, 1986). These feelings can be both states, which are transient, short-term affective experiences, and traits, which are stable tendencies (Watson \& Clark, 1984; Barsade \& Gibson, 2007). Specifically, states include emotions, defined as intense but short-lived affective reactions elicited by a particular target or cause (Frijda, 1993) and moods, defined as undifferentiated feelings with no specific target, which are ongoing for some period of time, and that permeate most of an individual's experiences (Zajonc, 1980; Clark \& Isen, 1982). In contrast, trait-based affect is a stable, underlying tendency to experience either positive or negative affective states (Staw, Bell, Clausen, 1986; Barsade \& Gibson, 2007).

Affective responses are extremely diverse and can range from love to fear to embarrassment. Several attempts have been made to create lists of distinct affective responses (e.g. Ekman, 1992; Frijda, 1986). However, two underlying dimensions valence and intensity - can be used to organize the spectrum of responses (Russell, 1980). When these dimensions are arranged as an $\mathrm{x}$ - and $\mathrm{y}$-axis, and a circle is overlaid on the axes, the 'circumplex' model is created (Feldman, Barrett, \& Russell, 1998). This model represents how affective terms group together by valence and intensity. For example, alert, excited, enthusiastic, elated, and happy, are all high valence and high intensity affective responses (Barsade \& Gibson, 2007).

In addition to classifying affective responses, a framework has been developed that describes the typical process of an emotional response. According to this model, 
when individuals are confronted with a stimulus, they first engage in emotion registration, which consists of three steps: granting the stimulus attention, making sense of the stimulus, and applying 'feeling rules', which are chronic goals (such as trying to experience the most positive affect possible) of the registration process (Elfenbein, 2007). After the emotion is registered, an individual engages in emotional experience, which consists of the mental awareness of the feeling state and the body's physiological response to the emotion. Finally, in emotional expression, the emotion process is shared with others in the form of expressive cues, such as words, facial expressions, body language, and vocal tone (Elfenbein, 2007).

Research has recently extended affect, as well as the emotional response model, to understand the outcomes of more complex constructs such as emotional contagion (Barsade, 2002), emotional labor (Morris \& Feldman, 1996), and emotional regulation (Grandey, 2000). Moreover, the superordinate construct of affect and the emotions, moods, and feelings it encompasses, have been shown to have a strong influence on several key outcomes. For instance affect plays a significant role in creativity (e.g. Amabile, Barsade, Mueller, \& Staw, 2005), decision making (Elsbach \& Barr, 1999), language (e.g. Lutz \& Abu-Lughod, 1990), and psychological well-being (Zapf, 2002). In addition to these extensive streams of research, there is a growing body of work demonstrating a relationship between affect and persuasion.

\section{Affect and Persuasion}

As recognized by Aristotle, the persuasiveness of a message relies on the interplay of three factors: characteristics of the speaker (e.g. credibility), characteristics of 
the message (e.g. its logicalness), and the feelings and emotions of the audience (Miceli, Rosis, Poggi, 2006). Attempting to persuade by appealing to an audience's emotions is a strategy used by politicians and marketers alike (Destano et al., 2004). Because of the ubiquity of this strategy in both public and private rhetoric, the psychological study of persuasion has paid particular attention to the link between affect and persuasiveness (e.g. Allport, 1935; McGuire, 1969; Eagly \& Chaiken, 1993; Desteno et al., 2004). The resounding finding from research in this literature is that the persuasiveness of messages, and hence our evaluations of the people, objects, and issues contained in them, is influenced by individuals' feelings, moods, and emotions (Petty et al., 1988). Moreover, the relationship between affect and persuasiveness holds regardless of whether or not affect is actually relevant to the content of the message.

\section{Dual Process Models}

How and why does affect have such a potent influence on persuasion? Much of the literature examining the relationship between affect and persuasion has used dual process models to answer this question (Dillard \& Peck, 1990). While unique, these models are all based on the assertion that when individuals evaluate a message they use two distinct, yet simultaneously interactive, processes. For instance, according to cognitive-experiential self-theory (CEST; Epstein, 1990) individuals use both an analytical process and an affect-based process when evaluating the persuasiveness of a message (Buck, Anderson, Chaudhuri, \& Ray, 2004). The analytical process operates largely at the conscious level and is intentional, rational, and reason oriented; whereas the affect-based system operates at a pre-conscious level that is automatic, intuitive, and 
experiential (Epstein, 1990). In evaluating a message, these two processing systems often interact seamlessly; however, when they conflict it is experienced as a struggle between feelings and thoughts (Nan, 2009).

In contrast, the Elaboration Likelihood Model (ELM) suggests that when individuals process a message the distinction is not between cognitive and experiential systems but rather between central and peripheral processing (Petty \& Cacioppo, 1986). Message processing that occurs through the "central route" involves careful scrutiny of the persuasive communication and a weighing of the merits of the message's argument (Petty, Briñol, \& Tormala, 2002). In contrast, processing through the "peripheral route" relies on less rigorous analysis of the message, such as reactions to the way it is presented, the attractiveness of the message source, and symbols or slogans contained in the message (Petty \& Cacioppo, 1986). Emotion is argued to play a much larger role in the peripheral route than in the central route.

Finally, the Heuristic-Systematic Model (HSM) is similar to the Elaboration Likelihood Model in that it argues that individuals respond to persuasive communication either systematically or through the use of heuristics (Chaiken, Liberman, \& Eagly, 1989). Systematic processing is contemplative, analytic, and focuses on the argument quality of a message (Dillard \& Peck, 2000). In contrast, with heuristic processing an individual relies on a shortcut to form their response to a persuasive message. In general, systematic processing is more time-intensive and requires more cognitive capacity than heuristic processing. The use of affect is considered one type of heuristic processing (Slovic et al., 2002). Specifically, when individuals are faced with a persuasive message 
(and, particularly, with complex or highly uncertain persuasive messages) they may implicitly ask themselves, "How does this message make me feel?" and use that feeling as a simplified form of message processing (Cesario et al., 2004). In this way, an individual's subjective state of affect is used as a heuristic, and a piece of information, in message evaluation.

\section{The Dimensionality of Affect}

Most empirical work examining the role of affect in persuasion treats affect as one-dimensional (Griskevicius et al., 2009). This work takes a valence-based approach that focuses on the effects of positive versus negative affect (e.g. Russell \& Carroll, 1999). Indeed, much of this research has focused on the differential effects of positive and negative mood (Desteno et al., 2004), which is often operationalized as happiness and sadness (e.g. Eagly \& Chaiken, 1993).

Studies taking a valence-approach have demonstrated several specific effects of positive and negative affect on persuasion. For instance, a message's affect can influence the complexity of the cognition individuals use to process the message. Specifically, positive affect is generally found to influence message persuasiveness by leading individuals to rely on simplistic thinking and mental shortcuts (Batra \& Stayman 1990; Schwarz and Bless 1991), whereas negative affect can have an opposite effect, leading individuals to think in a more complex manner. (Murry \& Dacin, 1996; Griskevicius et al., 2009). The affect of a message can also influence audiences' likelihood estimates. Specifically, when an event (e.g. contracting cancer or winning the lottery) is described in a message with negative (positive) affect, it generally inflates (deflates) an individual's 
likelihood estimate of the occurrence of the event (Desteno et al., 2004). Finally, message affect can also influence the perceived favorability of a judgment. Specifically, messages employing positive affect are often viewed more favorably than messages with negative affect (Mackie \& Worth, 1989).

There are two common explanations for the influence of affect on persuasionrelated cognition. First, positive affect is argued to lead to less message elaboration (i.e. less cognitive effort spent analyzing the information) because individuals want to maintain positive feelings and exerting effort can disrupt such feelings (Mano, 1997; Isen 1987). A similar logic holds for negative affect: individuals may try to eliminate such feelings by exerting cognitive effort to resolve the source of the negative affect. An alternative explanation of affect's influence is that individuals experiencing positive affect are simply less able to exert cognitive effort because positive affect disrupts cognitive capacity (Mano, 1997).

Research on the role of affect in persuasion is generally consistent in finding that positive affect is associated with enhanced persuasion while negative affect is associated with reduced persuasion (Petty et al., 1988). However, these findings are not universal. Both positive and negative affect have been found to increase, decrease, or have no effect on persuasion. For example, some find that positive affect actually increases systematic cognitive processing (e.g. Isen, 1993; Mano, 1992). The explanation provided for this finding is that when individuals process a persuasive message with positive affect they perceive the cognitive task as an enjoyable activity, which makes them more, rather than less, motivated to engage in extensive message processing (Mano, 1997). 
Disagreements in empirical findings and theoretical underpinnings have led researchers to look beyond simple valence-based explanations of the role of affect in persuasion. Indeed, it is argued that a complete understanding of the relationship between affect and persuasion cannot come from treating affect as a dichotomous, positive or negative, construct (Desteno et al., 2004; Petty et al., 1988). In an attempt to expand the conceptualization of affect, research has examined the relationship between persuasion and a wide-array of more granular affect variables. For instance, there is evidence that affect is at least two-dimensional and consists of pleasantness and arousal dimensions (Russell, 1980). For example, in a study of the persuasiveness of advertising messages, Mano (1997) finds that if participants are highly involved in the outcome of a message then high message-pleasantness increases cognitive elaboration but high arousal decreases elaboration. This finding illustrates that it is necessary to look beyond unidimensional models of affect because the two dimensions do not have the same influence on how individuals process persuasive messages.

In addition to examining the multiple dimensions of general affect, recent studies have focused on how discrete emotions influence persuasion. For example, Bodenhausen, Sheppard, and Kramer (1994) ask if all varieties of negative affect are alike in their influence on persuasion. They find that anger results in a greater reliance on heuristic cues in persuasion situations. More specifically, anger is associated with the level of agreement with an unpopular position being guided more by the credibility of the source. Similarly, Tiedens \& Linton (2001) find that compared to emotions associated with uncertainty (e.g. fear), emotions associated with certainty (e.g. hope) result in greater 
reliance on the expertise of the source of a persuasive message, more stereotyping, and less attention to argument quality. In a related study, Desteno, Petty, Wegener, and Rucker (2000) find that the congruency bias (i.e. the tendency for positive and negative affect to increase the likelihood estimates of future events matching the same affect) is not limited to valence but also functions in an emotion-specific manner. Specifically, they find that sadness and anger differentially bias likelihood estimates of sad and angering events (Desteno et al., 2000).

Two recent studies have demonstrated that to understand the relationship between affect and persuasion it is necessary to go even beyond the influence of specific emotions. In a study of message persuasiveness, Desteno et al. (2004) finds that attempts at persuasion are more successful when a messages is framed so that its emotional overtones (specifically, sadness and anger) match the emotional state of the message receiver (Desteno et al., 2004). In addition, in a study of the persuasiveness of consumer advertising, Lau-Gesk and Meyers-Levy (2009) find that there are three distinct properties of emotion (univalence, purity, and self-consciousness) that can influence the resources demands and, ultimately, the persuasiveness of an ad.

Overall, these studies provide convincing evidence that the influence of affect on persuasion is not a simple function of positive and negative valence. However, despite the growing number of studies that uncover relationships between affect-related variables and persuasion outcomes, it is argued that there is still "not much accord on how affect impacts the [persuasion] process itself' (Mano, 1997: 317). 
Narrative researchers have, however, examined how affect operates in narrative messages. This research can be used to shed light on precisely how affect impacts persuasion and, more specifically, on the potential persuasive effects of affect in resource acquisition.

\section{Narratives and Emotion}

A fundamental quality of narratives is that they often elicit an affective response in audiences (Schneider, 2007). This response may be the result of a multitude of factors including the narrative's imagery, characters, causal importance, intent, diction, and plausibility. Yet, the most common way to organize all of these factors is by using the distinction between emotions that are the results of the structure of the story, commonly referred to as "artifact emotions" and emotions that are the result of the content of the narrative, commonly referred to as "fiction emotions" (Kneepkens \& Zwann, 1995). Although the structure and content of a narrative can work together to produce an emotional response in an audience, these two types of narrative-induced emotions can occur independently. In other words, artifact emotion can occur without fiction emotion and vice versa (Oatley, 1994).

The sources of the two types of emotion roughly correspond to the distinction drawn in the literary criticism of the Russian formalists between a narrative's fabula and syuzhet. The fabula is the objective storyline in a narrative (i.e. the event structure, or "what happens"); whereas the syuzhet is the narrative's plot (i.e. the discourse structure, or "how the story is told") (Brewer \& Lichtenstein, 1981; Oatley, 1994). Both what happens in a narrative and how it is told, as well as the interaction of the two, can 
influence individuals' emotional responses to a story. Each of these sources of emotion content and structure - is examined in turn.

Emotional Responses to Narrative Content

An individual's emotional reaction to a narrative often stems from the content of the narrative (Tan, 1995). That is, what happens in the fictional or non-fictional world of a story can create an emotional response in audiences. The most emotionally salient element of content is often the characters or, more generally, the agents of the narrative (Dijkstra, Zwaan, Graesser, \& Magliano, 1994). Agents can be humans, groups, organizations, or any other entity that can take a primary role. Individuals react affectively to agents and to the actions, situations, and events they engage in (Schneider, 2007).

The extent to which an audience has an emotional response to the characters in a story depends on several factors, including the audience's empathy and the narrative's imagability and plausibility (Dijkstra et al., 1994). First, emotional reactions are more likely if audiences are able to empathize with agents and the situations they face (Schneider, 2007). Empathy results from a vicarious response to the perceived emotional experiences and contexts of others (Eisenberg \& Strayer, 1987). Empathic responses are largely dependent on another characteristic of narratives, their imagery (Goetz et al., 1993). In particular, empathy is a function of the audience's ability to mentally represent the agents' situation (Zillman, 1991). If an individual can form a mental image, then they 
can evaluate the agents, the situation, and the potential outcomes. This evaluation influences the level of empathy possessed by audience members ${ }^{26}$.

Finally, the plausibility of a narrative can also influence its likelihood of producing an emotional response (Hall, 2003). Plausibility is the extent to which a narrative's content agrees with the pre-existing, extra-textual beliefs held by an audience about what is reasonable or true (Leerssen, 1991). Put simply, a plausible narrative is one that "rings true" (Connelly \& Clandinin, 1990). Stories lacking plausibility are more difficult to imagine, to evaluate, and to empathize with (Dijkstra et al., 1994). Thus, they will be less likely to engender an emotional response.

\section{Emotional Responses to Narrative Structure}

In addition to content, individuals can also respond emotionally to a narrative's structural components (Tan, 1995). Variation in structure falls within two categories: stylistic features and plot structure. Variations in the stylistic (i.e. formal) characteristics of a narrative are often referred to as "foregrounding" (Miall \& Kuiken, 1994) These variations can occur at the phonetic, grammatical, or semantic levels (Miall, 1995). For instance, in laboratory studies, Dijkstra and colleagues (1994) and Miall \& Kuiken (1994) find that variations in the literary devices used, such as deviations in language, metaphors, repetition, and syntax, influence audiences' emotional responses to narratives. One mechanism underlying this relationship between emotion and stylistic features is defamiliarization. Specifically, novelty in stylistic components, such as unusual syntax,

\footnotetext{
${ }^{26}$ The evaluation component also suggests that emotion is dependent on the values an audience uses to make judgments (Dijkstra et al., 1994). Depending on the particular values held by an audience, they may or may not empathize with, and thus have an emotional reaction to, the agents in a narrative.
} 
can be defamiliarizing. When this is coupled with attempts at refamiliarizing, it evokes emotion (Miall \& Kuiken, 1994).

The plot structure of a story also influences a narrative's ability to create an emotional response in its audience. More specifically, structural affect theory (Brewer \& Lichtenstein, 1982) argues that there are particular patterns in the structure of stories that relate to distinct emotional responses. For instance, if an event that could lead to significant consequences (either good or bad) for one of the primary agents is presented early, and if the consequences are not immediately presented, then this will create suspense (Brewer \& Lichtenstein, 1982). Similarly, when a critical event is initially omitted and then inserted later in the narrative, this often leads to surprise. Other variations in the temporal presentation of a narrative's structure can evoke different emotions, such as curiosity, dread, and uncertainty.

To summarize, stories create emotional responses in several ways. Both the content of narratives, and particularly the characters and the situations they face, and the structural properties of narratives, including their stylistic features and how the plot is presented, interact to influence audience emotion.

\section{The Processes of Narrative-Induced Emotion}

The previous section describes the characteristics of narratives that can engender an emotional response; however, the question remains, beyond the identification of specific emotions (e.g. suspense or curiosity), what are the affective responses that individuals have to narratives and how do they operate? While there are a multitude of different emotions that a narrative can invoke, and an equally large number of ways that 
an audience can experience these emotions, there are four general processes through which individuals interact with narratives: sympathy, emotion recall, identification, and transportation.

Sympathy is a primary means of transmitting emotion and is also fundamental to the narrative form (Pinney, 1963). It involves a tendency to feel "near" the characters of a narrative, to express support for their goals, and to share in their accomplishments and failures (Tan, 1996). The major empathic emotions, such as pity, admiration, hope, and fear are all based on a basic sympathy concern (Tan, 1995). Stories invoke sympathy primarily through the actions and circumstances of their agents. For instance, if the characters achieve (or fail to achieve) a significant goal, the audience is likely to sympathize with this outcome (Dijkstra et al., 1994). In general, there is a positive relationship between the amount of sympathy invoked by a story and the likelihood that an audience will appraise it positively (Cupchick et al., 1998). Specifically, Andringa (1996) finds that feelings of sympathy are a positive predictor of a story's attractiveness. This relationship is moderated by the level of experience of the audience; however, contrary to expectations, the positive relationship between sympathy and (positive) appraisal holds for experienced but not inexperienced audiences.

A related process that evokes emotion is identification. With identification an audience goes beyond merely sympathizing with the goals and plans of narrative agents. Instead, it involves imagining what it is like to be the agent in a story (Tan, 1995). The distinction between identification and sympathy can be further clarified by using the analogy that to sympathize with the agents of a narrative is to become like a spectator in 
the narrative, whereas, to identify with the agents is to become like a participant (Oatley, 1999). There are several reasons why an individual might identify with a story. For example, individuals may desire to feel, and thereby to share in, the power or control of the agents (Cupchik et al., 1998). Moreover, they may also relate to the characters, for instance, because they are facing a similar life situation (Oatley, 1995). The outcome of identification is that an individual is more likely to see the agents" "physical and social world as if through his or her eyes" (Cupchik et al., 1998: 365) and, hence, to experience the same emotions as the characters they identify with (Tan, 1995). In other words, a story's ability to get an audience to identify with the emotions of its characters can result in the audience experiencing the same emotions.

As they make sense of a narrative, audiences can respond to it through processes - such as sympathizing or identification - that are conjured in the moment or through processes that are the result of an interaction between the story and emotional memories (Cupchik et al, 1998). The latter set of processes involves drawing on memories of situations when an individual has experienced emotions similar to those displayed by the characters in the narrative (Oatley, 1999). In this way, individuals' memories serve as a mediator between the emotions displayed by the agents in a narrative and the emotional reactions of the individuals. Thus, the emotions in a story act as a cue for recalling similar emotions from memory (Oatley, 1999). For instance, Larsen and Laszlo (1990) find that a narrative's personal resonance (i.e. the extent that content is related to personal experiences) is associated with the evaluation of the story. Specifically, the pleasantness, 
relevance, and aggressiveness of the memories evoked by a story influence an audience's appraisal.

A final process through which stories can invoke emotions, which underlies sympathy, identification, and emotional recall, is narrative transportation. Transportation is based on the metaphor that when audiences process stories they undertake a "mental journey" into the world of the narrative. In this process, "mental systems and capacities become focused on the events occurring in the narrative" (Green \& Brock, 2000: 701). The immersive mental state that results from this process relies on an integration of attention, imagery, and emotions (Appel \& Richter, 2010). Moreover, several activities occur when individuals are transported into a narrative. First, they temporarily lose awareness of their surroundings as their cognitive facilities become focused on the events in the narrative (Murphy et al., 2011). Second, the emotions invoked - in conjunction with their identification, sympathy, or memories - are heightened (Green \& Brock, 2000). Finally, when individuals "emerge" they often feel changed by having been deeply engrossed in the story (Murphy et al., 2011).

A narrative's ability to transport audiences is a strong predictor of its persuasiveness (Green \& Brock, 2000). Indeed, transportation is a general mechanism underlying persuasion in a number of studies (Escalas, 2007; Green \& Brock, 2000; Mazzocco, Green, \& Brock, 2007; Appel \& Richter, 2010). It influences persuasion by making an audience's beliefs more susceptible to the information contained in the narrative (Gerrig, 1993). More specifically, when individuals are transported, they devote most of their cognitive resources to the events occurring in a story, leaving them less 
cognitive capacity to devote to developing counterarguments to its assertions or to critically assessing the narrative's content (Murphy et al., 2011; Kreuter et al., 2007). In addition, transportation also influences persuasiveness because it is often associated with vivid mental simulations of the events represented (Appel \& Richter, 2010). These simulations lead individuals to overestimate the likelihood that the events are true or that they can occur (Johnson, Hashtroudi, \& Lindsay, 1993).

Several studies have demonstrated an empirical link between transportation and persuasion. For instance, in a study of narratives conveying information about cancer, Green (2006) finds that transporting stories change both beliefs (about illness) and motivations to take action. Indeed, transporting narratives are especially useful for conveying information because they reduce counterarguments, facilitate the mental simulation of unknown, difficult, or frightening procedures (e.g., screening), provide role models for behavior change, and create strong attitudes based on both cognition and emotion (Green, 2006). Similarly, in a study of fictional stories, Green \& Brock (2000) find that increased transportation leads to increased narrative-consistent beliefs and more favorable evaluations of the stories. However, one important factor that did not influence the relationship between transportation and persuasion was whether the story was presented as fact or fiction (Green \& Brock, 2000). Lastly, in a study of the persuasiveness of consumer advertising, Escalas (2004) finds that increased transportation is associated with favorable effects on attitudes about the advertisements and positive evaluations of the brands in the ads.

\section{Narratives, Emotion, and Persuasion}


Although several of the mechanisms influencing persuasion have been described in general models of persuasion, such as the Elaboration Likelihood Model (Petty \& Cacioppo, 1986) and the Heuristic-Systematic Model (Chen \& Chaiken, 1999), narrative's influence cannot be fully explained by these models (Appel \& Richter, 2010). The question remains, how does the emotion invoked by narratives influence persuasion? Work examining the role of transportation in linking narrative emotion to persuasion begins to answer this question. However, this stream of research is in a nascent stage, and represents just one potential process linking narratives, emotion, and persuasion. Thus, we have yet to develop a detailed understanding of how stories persuade audiences through emotion.

In general, humanities scholars have focused on the link between narratives and affect, but have shown little concern for persuasion; in contrast, social scientists, and particularly psychologists, have focused on the relationship between emotion and persuasion, but have not tried to understand the role of narratives in the process. Few studies have explicitly examined the three topics in consort.

There are, however, some findings that are suggestive of how narrative emotion may influence persuasion. For instance, there is evidence that emotions play a "selective role" in the processing of narratives (Kneepkens \& Zwaan, 1995). More specifically, emotion focuses audience attention on certain pieces of information to the exclusion of others. The attention given to this emotionally-salient (or emotionally-interesting) information often requires less cognitive resources than attention given to other information (Wade, Alexander, Schraw, \& Kulikowich, 1995). Information that is more 
likely to be selected and information that is easier to process are both more persuasive (Shah \& Oppenheimer, 2007).

Similarly, narrative emotion may also influence message persuasiveness by acting as a "back-up" to cognitive processing. More specifically, as dual process models (described above) suggest, there is evidence that when cognitive mechanisms are unable to process a message (e.g. due to message complexity, or uncertainty) that emotions are used to help individuals decide what pieces of information are relevant and, more broadly, to facilitate understanding (Dyer, 1983; Kneepkens \& Zwaan, 1995). Once again, the function of emotions is to narrow (and simplify) the information granted attention. The preferential treatment given to some pieces of information, and to some messages, will increase their persuasiveness.

Despite the suggestiveness of these findings, the conclusions drawn about the inter-relationship between narratives, emotion, and persuasion are indirect and speculative. Thus, more focused-work is needed in order to understand how narratives influence persuasion through emotion and, particularly, the role played by these factors in resource acquisition. 


\section{Appendix C:}

\section{A Review of the Practitioner Literature and Evidence from Pilot Interviews}

In this chapter, I describe evidence from two sources. First, the practitioner social entrepreneurship literature is reviewed. As explained above, an initial investigation of this literature (along with pilot interviews) revealed that several specific topics, such as the interplay between narratives and emotion, are explicitly argued to play a key role in resource acquisition. Practitioner writings highlighting the presumed importance of these factors are described.

Second, evidence from 12 pilot interviews is described. Although the number of interviews is limited, preliminary analysis confirms that social enterprise resource acquisition is an important phenomenon. It also suggests that several factors (e.g. narratives, emotion, organizational form) may influence social entrepreneurs' ability to acquire resources.

\section{Evidence from the Practitioner Literature}

Within the practitioner social enterprise literature there is widespread agreement that social entrepreneurs face unique (and substantial) resource acquisition challenges (e.g. Spors, 2008; Macsai, 2008; Kim, Perreault, \& Foster, 2011). Moreover, it is commonly asserted that the sector is in "desperate need" of a better understanding of how to effectively navigate these challenges (Trexler, 2010; Dees, Emerson, \& Economy, 2001). However, there is considerable debate about the strategies that are most effective for acquiring resources. In particular, although it has received virtually no attention in the 
academic literature, one of the most contentious discussions concerns how social entrepreneurs use narratives to persuade resource providers (e.g. Pekar, 2011; Richardson, 2011).

Several practitioner-focused journals (e.g. Stanford Social Innovation Review) and media outlets (e.g. Social Edge) have published articles detailing the critical role played by narratives in social entrepreneurship resource acquisition. Indeed, it is argued that "at its core, social entrepreneurship is about introducing a new story of social innovation - and convincing others to believe in your market-based solution" (Margolis, 2007). Practitioner belief in the importance of narratives is evidenced by numerous examples of firms hosting "storytelling workshops". For instance, the Skoll Foundation, the world's largest foundation focusing on social enterprise, recently hosted a session titled, "Storytelling in the modern world". The session detailed how "film and media can take positive messages to mass audience[s] with the goal of influencing strongly-held attitudes and behaviors... and how popular culture and a well-told story can accelerate social transformation" (Social Edge, 2009). Moreover, Skoll's website provides a clear description of how the organization sees narratives playing a role in social innovation: "we believe in the power of storytelling both to make vivid the world's most pressing problems and to articulate specific solutions with potential for large-scale impact (Skoll Foundation, 2011).

The number of firms hosting storytelling workshops is coupled with a growing number of "narrative consultants." These individuals are professional storytellers who advise social entrepreneurs on how to communicate to stakeholders through narratives. 
For instance, Michael Margolis, the founder of Thirsty-Fish Consulting and Get-Storied, helps "business[es] and social innovators find the essence of their story and make it real to those constituents that matter most" (Margolis, 2007). By showing organizations how to develop and harness a concise narrative he "enables [them] to shift perceptions, raise money, and reframe conversations (Margolis, 2007) ${ }^{27}$.

The demand for storytelling workshops and consultants, and, more generally, social entrepreneurs' interest in narrative communication seems to be the result of a belief that narratives have a greater influence on stakeholders, and particularly resource providers, than non-narratives. For instance, as one social entrepreneur claims, "before, we tried to let the statistics speak for themselves. But guess what? They don't. They're not memorable" (Bianchi, 2005). Andy Goodman, a storytelling consultant for nonprofits and social enterprises, expresses a similar sentiment, "Numbers numb, jargon jars and nobody ever marched on Washington because of a pie chart. If you want to connect with your audience, tell them a story" (Bianchi, 2005).

It is argued that this "connection" is, in part, attributable to narrative's ability to transmit emotion. As Margolis insists, "Great stories are driven by sincere emotion. This kinetic energy is what engages people, and gets your audience to invest in the outcome of your story. We make choices based on feeling, not reason. Your story must establish an emotive connection" (Margolis, 2007).

\footnotetext{
${ }^{27}$ Narrative workshops are not just the domain of social entrepreneurs. Margolis, for example, has led internal story workshops for purely for-profit corporations and traditional non-profits, such as AARP, Ernst $\&$ Young, Marriott, NASA, National Audubon Society, PBS, The Nature Conservancy, UN Foundation, and the YWCA.
} 
In addition to the belief that narratives are more influential than non-narratives, there is also a belief that stories play a role in several issues that practitioners believe are unique to social entrepreneurship, but that may in fact be generalizable to other contexts. For example, social entrepreneurs struggle with balancing their social and economic missions. When pitching their business to potential investors, this leads them to be unsure of whether they should emphasize a social or commercial message. As Smith (2011a) asks, “...in a world where social enterprise isn't well understood and people think in pretty black and white terms about charity and business, how do you balance your social and business message? Which comes first, and does it really matter whether people understand your social mission at all?"

Finally, despite the benefits of using narratives, social entrepreneurs also recognize that there are challenges to relying on narrative communication. It is argued that "there are a lot of pitfalls out there to storytelling" (Dunn-Solomon, D., quoted in Bianchi, 2005). For instance, “[g]etting the message right is going to be vital for social enterprise. But what should the message be and how should it be delivered?" (Smith, 2011a). Similarly, there are questions about when narratives should be used and for what types of resource providers. As Moore (2011) explains, "Metric-heads insist on quantitative measures that "prove" an initiative's ROI, while story-huggers opine that numbers can't ever convey the value of lives transformed. Who's right?" As these examples illustrate, uncertainty exists within the social entrepreneurship sector about how narratives can and should be used to communicate about social ventures. 
The following section expands on each of the preceding issues. First, practitioner arguments about how narratives influence stakeholders are described. Specifically, the types of narratives that are argued to be effective and the effects these stories can have on audiences are reviewed. Particular influence is placed on the presumed role of emotion in narrative communication and on the use of narratives in securing resources. Next, the issues practitioners view as unique to using narratives to communicate about social enterprises are described. Finally, several practitioner-identified challenges, open questions, and uncertainties regarding the use of narrative communication in resource acquisition are discussed.

\section{Using Narratives: Practitioner Perspectives}

Practitioners in the social enterprise sector have identified several ways that narratives can be influential in communication with stakeholders. These include creating awareness for social ventures and the issues they address, building relationships and communicating with diverse audiences, changing existing beliefs and forming new perceptions about what is possible, and engendering commitment and securing resources. Viewpoints on each of these uses of narrative are examined in turn.

First, before audiences can be asked to act (e.g. to donate funds, to volunteer), social entrepreneurs must create awareness about the social problem they are targeting and their social venture. Practitioners argue that social entrepreneurs can use stories to influence stakeholder attention (Smith, 2011b). For instance, narratives are argued to be useful for "capturing public imagination" (Smith, 2011a). Stories also are said "help people to see something [they] tend to ignore or overlook" (Margolis, 2007). For these 
reasons, social entrepreneurs are advised to tell stories that "create awareness" and to “make sure [their] social enterprises' messages engage, inspire, and enthuse - like any good story. It's only by doing this that public awareness will grow...” (Smith, 2011b).

Once audiences are aware of a social enterprise and the social problem it is addressing, practitioners argue that narratives are valuable as communication tools that can be used to connect with audiences and build relationships. Narratives are argued to "allow larger audiences to understand and connect to [social] issues" (Goldman, 2008). They do so by "explaining something complex or hard to believe in an understandable way" (Goldman, 2008). When audiences understand the aims of a social enterprise and its targeted social problem, relationships can be formed. As Larry Weisberg, the director of Faith in Action, states, "Telling stories has become one of the most powerful aspects of what we do...it's about relationships between the people who help and the people who are helped ${ }_{[,]}$something we share through stories" (Bianchi, 2005). The ability to appeal to diverse audiences (funders, volunteers, consumers, etc.) is viewed as fundamental to the success of a social venture. In fact, there are workshops devoted solely to the topic. For instance, at the Skoll World Forum, one of the premier conferences on social enterprise and co-produced by the Skoll Centre for Social Entrepreneurship at Oxford University, there is a recurring workshop ("Winning hearts and minds: The power of a well told story") that addresses how social entrepreneurs' "ability to speak to multiple audiences could be the key to [their] success and the source of [their] greatest challenges" (Social Edge, 2008). Narratives can thus be used to connect audiences to a social 
enterprise and the social problem it is addressing, and to create relationships with these audiences (Sample-Ward, 2008).

Practitioners insist that it is not sufficient for social entrepreneurs to just convey their message to audiences; rather, they must often change stakeholders' beliefs about social issues. For instance, it is argued that "social entrepreneurs have to do more than present compelling solutions. They need to change long-standing beliefs in favor of new ways of thinking..." (Skoll World Forum, 2009). In addition to changing existing beliefs, it can also be necessary for social entrepreneurs to fundamentally alter audiences' perceptions about future states of affairs (Margolis, 2007). In other words, entrepreneurs must "open minds" to entirely new possibilities (Herz \& Mertes, 2008). Narratives are believed to be particularly well-suited for changing individuals' beliefs about what is possible. Indeed, it is argued that our notions of natural order and possibilities hinge on the narratives in which we are exposed (Marino, 2010). For instance, if audiences are provided with a narrative describing how a goal can be achieved, it is argued that they are more likely to pursue that goal than audiences provided with a story describing how the goal cannot be achieved (Marino, 2010). If social entrepreneurs desire to "change someone's perspective on an event, person, place, or issue" practitioners advise that narratives are the preferred form of communication (Sample-Ward, 2008).

In addition to creating awareness, forming a connection with audiences, and changing audience beliefs, practitioners believe that narratives can also be used to fulfill a final objective: getting audiences to become actively involved in the social venture. In general, involvement consists of two stages, getting individuals to become engaged with 
(or "buying-in" to) a venture's mission and getting individuals to commit resources. Practitioners argue that stories are effective in achieving both objectives.

First, it is argued that "if you can weave a compelling narrative about your institution, your idea, and your vision, you can build a strong case for community buy-in (Tobin \& Finger, 2011). Similarly, it is believed that stories can be used to "engage, inspire, and enthuse" (Smith, 2011a). As Becky John, founder of whomadeyourpants? (a social venture focused on providing employment for marginalized women) claims, through stories "people buy more than our products - they buy us, and they buy our business model as a vehicle for change. I think perhaps they buy the hope that things can change." These statements suggest that social entrepreneurs feel it is necessary for audiences to commit to more than their products. Second, audience engagement with an organization, and the stories it tells, is believed to be at the heart of decisions to give resources to a social venture. For example, it is argued that "donors don't really give to a program or organization; they invest in the bigger story. In other words, donors give to issues where they feel a direct personal connection. Your work must mean something to them, or else their dollars go to a cause that does" (Margolis, 2007). Thus, practitioners believe that stories and resource acquisition are intimately linked.

\section{Emotion and Social Enterprise Narratives}

There seems to be a common factor underlying narrative's ability to influence stakeholder awareness, relationship formation, belief change, and resource commitments: emotion. First, practitioners assert that narrative's ability to create an emotional response in audiences draws attention and creates awareness. For instance, as Ni (2008) argues, 
"stories are emotionally arousing and it is emotions that trigger the impetus to help," and "there's so much advertising clutter in the world that you need to focus on catching people's attention and moving them to act by triggering emotion."

Similarly narrative emotion is also thought to play a role in social entrepreneurs' ability to make connections with audiences. It is argued that "stories must establish an emotive connection" because this "compel[s] someone into wanting to be a part of what you do." (Margolis, 2007). Narrative emotion also influences beliefs and perceptions. As Margolis (2007) explains, "most social entrepreneurs must ask others to reframe some of the basic assumptions that we all take for granted. That's why reason alone cannot overcome the intractable forces of culture. You need a story that inspires and emotionally connects to what people care about." Finally, the emotional responses created by narratives play a role in the extent that audiences buy-in, and commit resource to, an organization. Regarding buy-in, it is believed that social entrepreneurs' communication with stakeholders "must engage, excite, [and] win people over to what social entrepreneurs do and how they do it. Winning people over is about...engaging hearts and minds - about sharing stories" (Smith, 2011a). The effects of narrative emotion can

ultimately influence resource acquisition. As Alberto (2011) explains, "due diligence is key to the [funding] process, but the emotional appeal of your idea and the way you communicate it to funding organizations can make a huge difference."

\section{Narratives and Resource Acquisition: Practitioner Debates and Open Questions}

Although social entrepreneurship practitioners describe the importance of narratives and emotion in acquiring resources from stakeholders, they offer little or no 
explanation of, precisely, how stories influence resource providers. Moreover, practitioners are quick to note that there are a host of unanswered questions regarding the use of narratives as a communication tool. As Herz and Mertes (2008) explain, "social entrepreneurs understand the power of a well told story...but they don't always know how to harness that power to drive awareness of their issue and adoption of their innovation." In particular, practitioners' unanswered questions seem to cluster around four general topics: (1) who should be the focal characters of social enterprise narratives, (2) what content should be included in the narratives, (3) are narratives and statistical evidence opposing or complementary, and (4) should social or economic narratives be emphasized?

One of the most significant, unresolved questions, which is directly relevant to how social entrepreneurs acquire funding, is what content makes social enterprise stories persuasive with external stakeholders? For example, some argue that the most effective narratives utilize “obstacles”. As Bianchi (2005) explains:

\footnotetext{
The stories [social enterprises] use are as varied as the organizations themselves, but the good ones all have at least one thing in common: obstacles. While the temptation will always be to jump to the happy ending (and what your fabulous organization did to bring it about), good storytellers know to prolong this moment by throwing obstacles in the way. To paraphrase legendary Hollywood screenwriting guru Robert McKee, a good story proceeds as follows: "Act I: Get you hero up a tree. Act II: Throw rocks at him. Act III: Bring him down."
}

In addition to using obstacles, it is argued that there are also different themes that should be emphasized. Roshan Paul, who is listed as the Ashoka's Foundation's “expert in public narrative," claims that a compelling narrative must contain three sub-narratives: the story of "self", the story of "us", and the story of "now" (Tobin \& Finger, 2011). The 
story of self focuses on the social entrepreneur and describes who they are and how they got to the point of founding their social venture. It often includes the story of the "transformative moment", where the individual decided to pursue social entrepreneurship. The point of this story is to capture audience attention by telling a personal narrative of why the social entrepreneur has chosen this particular work. In contrast, with the story of us, social entrepreneurs focus on communicating to their audience about their community and about how their audience's experiences mesh with theirs. The goal of this story is to create unity between the social entrepreneur and his or her audience. Unity is claimed to be important because it "can inspire others to support, and potentially fund, [one's] cause" (Tobin \& Finger, 2011). Finally, with the story of now, the social entrepreneur concentrates specifically on what they need, why it is pressing, and the action they require. This story is argued to be more compelling if the social entrepreneur has successfully established a connection to their audience through the story of self and us.

Although the story of self-us-now framework is intuitive, it is not universally accepted. In particular, placing emphasis on the social entrepreneur (in the story of self) has received criticism. There is currently a debate in the practitioner literature about who should be emphasized as the focal characters, or protagonists, in social enterprise narratives. One camp argues that a social entrepreneur (either the founder of the venture or other successful social entrepreneurs) should be at the center of the stories. It is claimed that "social entrepreneurs are the sexy ones in the eye of the media - not their communities" (Richardson, 2011). Moreover, practitioners argue that "individual social 
enterprises have to get better at developing their own stories and revealing their own personalities... why they set up the business, their inspirations, their passions, their struggles and challenges and how they've overcome them" (Smith, 2011a).

This viewpoint is contrasted with those who believe that an individual associated with the social issue (e.g. a homeless person, malaria patient, or natural-disaster victim) should be center stage in social enterprise narratives. Proponents of this view ask, "what is it that holds social enterprises back from talking about the lives and communities they transform through sustainable change? They often articulate their social mission, but it's rare for them to put the people they do it for - and with - at the center of their narrative" (Richardson, 2011). Thus, there is debate about "whose point of view you tell the story, so that your listener most closely relates to the challenges and successes you present?" (Pekar, 2011).

A final debate centers on whether social entrepreneurs are more persuasive if their narratives emphasize their economic mission, their social mission, or some combination. Moreover it is not clear which of the two missions the entrepreneurs should "lead" with when communicating with resource providers as well as what factors moderate that decision. Some argue that the economic mission is the most persuasive to emphasize. For example, Sarah Dunwell, chief executive of the Create Foundation, a UK-based social enterprise, argues that even though she considers her venture a "for more than profit" company, the economic message is the focus of her communication.

"Quite honestly, we don't care whether people are interested in our social mission at all. People buy from us because we're competitively priced, because we have fabulous products and services and offer a brilliant consumer experience. If they choose to be motivated by our social mission, that's great. If 
they don't we're not particularly bothered. Those social enterprises that struggle are the ones that lead with their social message and follow with the business message." (S. Dunwell, quoted in Smith, 2011).

In contrast, some social entrepreneurs believe that it is the social message that distinguishes social entrepreneurs from their conventional counterparts and, thus, can be used as a source of differentiation in the marketplace. For example, Richardson (2011) argues,

Yes, social enterprises have to do good business - they have to compete with private companies. But leveraging the people part of their brands [i.e. their social message] is critical to giving them an edge.

Finally, there are still other practitioners who claim that the distinction between a social entrepreneur's social and business message is not so easy to define. Becky John, founder of whomadeyourpants? argues that the economic and social elements of a social enterprise should be viewed as interdependent rather than separate.

Our first sell is about our gorgeous pants, but then we go into our social story. People don't have to know our [social] story to love the product - but I think they like it even more if they do know. For us our social and commercial messages are completely meshed together. We can't achieve our social aims without the business working and we can't be a viable business without achieving our social aims. Our social mission is threaded through absolutely everything we do. (B. John, quoted in Smith, 2011).

The three viewpoints illustrate the unresolved tension social entrepreneurs face about what message they should emphasize. The quotations also suggest that there is little consensus among practitioners about how social entrepreneurs should communicate about their social and economic missions. Moreover, there is even less consensus about whether the choice between a social or economic-focused narrative depends on the 
particular type of audience addressed (e.g. philanthropists, social venture capitalists, private foundations, potential volunteers or employees).

Indeed, despite claims about the primacy of narrative, and the increasing number of practitioner articles and "lay" theories about the topic, the use of narratives in social enterprise resource acquisition is not clearly understood. This gap in the practitioner literature is intriguing because, as described above, it corresponds to a similar, theoretical gap in the management literature examining narratives: a lack of work examining narrative's ability to create an emotional response in audiences. This issue also emerged in pilot interviews.

\section{Evidence from Pilot Interviews}

A pilot study was conducted with both social entrepreneurs and social (i.e. "impact") investors. There were several objectives of the study including gaining a better

understanding of the social enterprise context, getting preliminary insights into social enterprise resource acquisition, uncovering attributes important to the methodology design, and refining and shaping the final interview guides. Twelve individuals in the social enterprise sector were formally interviewed (Table 13). Also, observations and informal interviews were conducted at three, practitioner-focused social enterprise conferences (all of which included funding competitions). Finally, I engaged in direct, participant observation of a pitch by a social entrepreneur to a large, corporate donor.

The informants comprising the pilot study were selected based on several criteria. First, and foremost, they had to be involved in the social enterprise sector on the venture creation or funding side. More specifically, individuals were selected to get perspectives 
from the following groups: early (i.e. start-up) social ventures, growth-stage ventures, and for-profit, non-profit, and hybrid ventures. Also, funders were identified from a philanthropic family foundation, a grant-giving private foundation, and a social venture capital fund. Other informants were identified through snowball sampling.

Interviews were semi-structured, lasting approximately an hour in duration, and included a combination of closed- and open-ended questions. Interviewees were first asked to provide background information about their prior work experience and education. Social entrepreneurs were then asked to describe the founding of their current venture. Particular attention was placed on the decision to form a social enterprise and decision to form as for-profit, nonprofit, or hybrid. Each entrepreneur was then asked how they have funded their venture to this point (both financial and nonfinancial resources). Informants were also asked about prospective sources of funding (i.e. what resource acquisition attempts they had planned). After this series of specific questions, interviewees were asked more exploratory questions about their perspectives on the role of narratives and emotion in social entrepreneurship. I concluded each interviews by asking informants if there were anyone in the social enterprise sector that they would recommend that I contact.

Interviews with resource providers focused on recent funding decisions and on the criteria used to choose between investments. Funders were also asked for their perspective on the role of emotion and narratives in social investment decisions. All interviews were transcribed by the author within 48 hours of the interview date. 
TABLE 13:

DESCRIPTION OF PILOT INTERVIEW PARTICIPANTS

\begin{tabular}{|c|c|c|c|}
\hline INFORMANT & POSITION & ORGANIZATION & DESCRIPTION \\
\hline $\begin{array}{l}\text { Informant_1 } \\
\text { (Funder) }\end{array}$ & Executive Director & $\begin{array}{l}\text { Private Family } \\
\text { Foundation }\end{array}$ & $\begin{array}{l}\text { Charitable } \\
\text { foundation of a } \\
\text { high net-worth } \\
\text { individual }\end{array}$ \\
\hline $\begin{array}{l}\text { Informant_2 } \\
\text { (Funder) }\end{array}$ & President, Founder & $\begin{array}{l}\text { Social venture } \\
\text { capital fund }\end{array}$ & $\begin{array}{l}\text { A 'double bottom } \\
\text { line' venture } \\
\text { capital fund }\end{array}$ \\
\hline $\begin{array}{l}\text { Informant_3 } \\
\text { (Social } \\
\text { Entrepreneur) }\end{array}$ & Founder, CEO & $\begin{array}{l}\text { For-profit social } \\
\text { enterprise }\end{array}$ & $\begin{array}{l}\text { Developed a } \\
\text { training module } \\
\text { designed to help } \\
\text { individuals become } \\
\text { social } \\
\text { entrepreneurs }\end{array}$ \\
\hline $\begin{array}{l}\text { Informant_4 } \\
\text { (Social } \\
\text { Entrepreneur } \\
\text { Funder) }\end{array}$ & $\begin{array}{l}\text { Executive } \\
\text { Director, Founder }\end{array}$ & $\begin{array}{l}\text { Economic } \\
\text { development, non- } \\
\text { profit organization }\end{array}$ & $\begin{array}{l}\text { A development } \\
\text { organization that } \\
\text { tries to discover } \\
\text { innovative business } \\
\text { ideas in } \\
\text { economically } \\
\text { depressed areas. }\end{array}$ \\
\hline $\begin{array}{l}\text { Informant_5 } \\
\text { (Social } \\
\text { entrepreneur) }\end{array}$ & Founder & $\begin{array}{l}\text { For-profit social } \\
\text { enterprise }\end{array}$ & $\begin{array}{l}\text { Online donations } \\
\text { (failed) }\end{array}$ \\
\hline
\end{tabular}


TABLE 13 (cont.)

\begin{tabular}{|l|l|l|l|}
\hline $\begin{array}{l}\text { Informant_6 } \\
\text { (Social } \\
\text { entrepreneur) }\end{array}$ & Founder, CEO & $\begin{array}{l}\text { Hybrid (nonprofit } \\
\text { parent company } \\
\text { with for-profit and } \\
\text { nonprofit } \\
\text { subsidiaries) }\end{array}$ & $\begin{array}{l}\text { Provides consulting } \\
\text { for individuals, } \\
\text { businesses, and } \\
\text { nonprofits. }\end{array}$ \\
\hline $\begin{array}{l}\text { Informant_7 } \\
\text { (Funder) }\end{array}$ & $\begin{array}{l}\text { Chairman of } \\
\text { Board of } \\
\text { Directors, Director } \\
\text { of International } \\
\text { Giving }\end{array}$ & $\begin{array}{l}\text { Nonprofit; Private } \\
\text { Family Foundation }\end{array}$ & $\begin{array}{l}\text { Incubator for faith- } \\
\text { based social } \\
\text { enterprises; }\end{array}$ \\
\hline $\begin{array}{l}\text { Informant_8 } \\
\text { Social } \\
\text { entrepreneur) }\end{array}$ & Director & $\begin{array}{l}\text { Charitable } \\
\text { foundation of a } \\
\text { high net worth } \\
\text { individual }\end{array}$ \\
\hline $\begin{array}{l}\text { Informant_9 } \\
\text { (Funder) }\end{array}$ & Director of R\&D & $\begin{array}{l}\text { Fortune 500 } \\
\text { consumer products } \\
\text { organization }\end{array}$ & $\begin{array}{l}\text { Provide food and } \\
\text { clothing for low- } \\
\text { income individuals }\end{array}$ \\
\hline $\begin{array}{l}\text { Informant_11 } \\
\text { (Social } \\
\text { entrepreneur) } \\
\text { for low-income } \\
\text { children }\end{array}$ \\
\hline $\begin{array}{l}\text { Informant_10 } \\
\text { (Social } \\
\text { entrepreneur) }\end{array}$ & Founder, CEO & For-profit & $\begin{array}{l}\text { Provides an online } \\
\text { platform for } \\
\text { making } \\
\text { contributions to } \\
\text { social causes. }\end{array}$ \\
\hline Nonprofit & $\begin{array}{l}\text { Offers automatic, } \\
\text { online donations to } \\
\text { charitable } \\
\text { organizations }\end{array}$ \\
\hline
\end{tabular}


TABLE 13 (cont.)

\begin{tabular}{|l|l|l|l|}
\hline $\begin{array}{l}\text { Informant_12 } \\
\text { (Social } \\
\text { entrepreneur) }\end{array}$ & Managing director & $\begin{array}{l}\text { Hybrid (nonprofit, } \\
\text { creating forprofit } \\
\text { subsidiaries) }\end{array}$ & $\begin{array}{l}\text { Takes a theoretical } \\
\text { approach to } \\
\text { tackling social } \\
\text { problems }\end{array}$ \\
\hline
\end{tabular}

Interviews confirmed that informants face issues similar to those discussed in the practitioner literature. For example, not only is resource acquisition claimed to be a key issue, but social entrepreneurs emphasize using narratives to form connections between their ventures and resource providers. Moreover, emotion seems to be one factor influencing this connection. Informants also claim to alternate between narratives that emphasize their ventures' social and economic messages. They do so, in part, because different groups of resource providers are argued to prefer one type of message over the other. Interviewees also provided unique insights about the role organizational form and structure play in investment decisions. Preliminary evidence pertaining to each of these topics is examined in turn.

\section{The Value of Narrative Communication in Resource Acquisition}

Pilot interviews provide further evidence of practitioners' belief in the power of narratives to acquire resources. First, several informants communicated that stories play a significant role in funding and investment decisions and, more generally, in resource acquisition. For instance, Informant_1, an associate at a large venture capital and private equity fund, stated,

I mean, if you're fundraising for a social enterprise, you have to tell stories, right? Storytelling is what raises funds in any context. An entrepreneur coming 
into [informant's large VC firm] has a story. If you don't have a good story, you're not going to get the results you want.

Informant_2, the co-founder of a social enterprise in the financial services sector, expressed a similar idea.

I've just observed: you don't close deals with IRR, you close deals with stories. And you close deals with human connection. No one is going to give you 25 million dollars because of a mathematical calculation.

The idea that narratives help to create a "connection" between the resource providers and the social entrepreneur (or the social venture) is another recurring theme. Specifically, Informant_1 explains that it is often the founder's story that gets audiences to "buy-in" and to identify with the social entrepreneur and his or her vision.

Look at Lance Armstrong. Here's a great cyclist, who's won all of these championships, but without that whole story of him beating cancer, his foundation gets nowhere - it's like any other celebrity foundation. But that story created this brand, that now is literally world-wide and worth a billion dollars...I think the reason that [story] resonates with a bunch of other people is because they're like 'wow, I wish I could do that, I want to do that, I want to be a part of that whether it's by paying a little bit of money. I want to express my support for that whatever I can do, but, I want to be a part of that. I want to feel connected to that... I want to wear that wristband that Lance did. But while I might not be going through the same kind of stuff, I'm going to live my life the same way.

Stories create connections not only by sharing the mission of a social enterprise, but also

by providing audiences with a means to communicate to others about the venture and to feel as though they are part of the story.

That's another piece that I think is, that I see as an opportunity. In some of the most interesting social enterprises - the most successful ones - I think one of the reasons that they're so successful is that there's a story behind it. There's a vision that people get, that they share, because 'now I can tell that story, I can be part of the whole...movement.' 
However, it is argued that social entrepreneurs cannot tell just "any" story. Instead, there is an understanding that in order to get audiences to identify with your venture, stories have to be told in a certain manner and must possess specific content. Informant_3, the founder of a social enterprise that helps individuals become entrepreneurs, explains how narratives should be constructed.

Understanding the perspective of who you are telling the story to is really important, unless you curated your audience, which means that you are really just preaching to the choir. You have to frame it as something that connects with who they are and what's meaningful [to them]. And this goes into how you pitch to investors too. It's not just...saying, well, 'here's what I am, here's what I do, here's my product'. If you don't understand what that person cares about then they're not going to care what you care about.

Social entrepreneurs without refined narratives are, arguably, at a competitive disadvantage. Informant_4, the founder of a social impact fund that invests in economic development explains why having a story is necessary.

You have to [have a story]. Because investors are interested in more than just the bottom line. So if you don't, if you don't tell a story, if you don't show the social element, you are in essence competing against other social ventures for social capital.

But still, questions remain. For instance, why are narratives necessary? And, how precisely do stories influence resource providers?

\section{Emotion and Social Enterprise Communication}

The statements of social entrepreneurs and funders suggest that emotion is at the center of why stories are able to influence audiences.

[VCs] have seen tons of [business] plans. What captures people, what gets people to pull out the checkbook, or authorize the wire transfer, is the emotional connection and that comes from stories. 
However, there is debate about whether emotion indeed plays a role in the social enterprise sector and, thus, if social entrepreneurs should embrace the use of emotional messages. Informant_1 argues that it depends on the organizational form. Specifically, he argues that because of the nature of non-profits, they are the only context where emotion matters for investment.

They [nonprofits] have to. They've evolved to be so [emotion-driven] just because of the product that they're selling. The product they're selling is social change. It's fixing pieces of the market that are broken or else they'd be solved by for-profits. So there's a breakdown of the market. Poor people can't get $\mathrm{XYZ}$, we're going to step in and provide that. But the only way we can sell that service is to pull on heart strings. Nonprofits are always going to pull at your heartstrings and try to make it much more emotion driven. 'Look at these poor kids that we're serving.' 'Look at how big this problem is.' Not trying to shame you into it, but if they do it right, the best fundraisers help you feel like you're a part of that solution and help you to have that expressive tie - of this is a one-toone kind of thing - you know, you are the catalyst that's helping to change this person's life and that's a great thing. That's emotional, right?

In contrast, he argues that social enterprise investors do not (and, arguably, should not) value appeals based primarily on emotion.

Whereas, I think the social entrepreneur side of philanthropy is trying to segregate that and say 'no, no, no - you can talk to me about orphans all you want, but I'm going to kind of close myself off from that because I think a lot of people feel like they let their guard down when they do that. You know, 'I spent all of this effort making this money and I was so rigorous about how I did it, that I don't want now to then just kind of say 'well this sounds like a good cause, they're doing good works, so I really don't care so much. I'm going to hold these guys accountable. I want just as much out of my investment in these social funds as I want on my investments from my personal portfolio.' Yes the emotion is there, but check it at the door. Bring your hard-nosed market analysis to this and say, 'I don't care if it's one or two kids better, I want to know, for the dollar, show me what the biggest impact is'?

Moreover, Informant_1 argues that emotion is a non-factor in the context of traditional entrepreneurial funding. 
Is the VC...less emotion driven than the social entrepreneur? Sure. Because there's one and only one calculation at the end of the day: what's the IRR on my investment.

In addition to the belief that emotion should not play a role in social enterprise investment, the idea also surfaced that social entrepreneurs should not rely on emotional messages.

To me, if people who are within the social entrepreneurship space want to be taken seriously, they need to be talking about long-term value generation and less about 'my passion' or stuff like that. If you focus on long-term value generation the other things will inherently follow.

In contrast, other informants argue that emotion has a universal influence, regardless of the type of organizational form or organizational investor, considered. For instance, Informant_2 explains why describing social investors as emotional and traditional investors as unemotional, is creating a false dichotomy.

I would say emotion still plays a tremendous role with [traditional] VCs. In the VC model there is a lot of emotion and a lot of qualitative inputs. Why do they have the entrepreneur come in and pitch? Why do they spend so much time? So VCs are factoring all of that non-quantitative stuff in there.

Thus, debate exists about if there is indeed a role for emotion in social enterprise communication and resource acquisition.

The Choice Between Economic and Social Messages

As previously described, a similar but more fundamental debate centers on what messages social entrepreneurs should emphasize: narratives focusing on a venture's economic mission or social mission. Even in the small sample of pilot interviews, this issue was contentious. Some informants were adamant in arguing that social enterprises should focus primarily on building and communicating their financial mission. 
I don't want the feel-good, social part...it's a subsidy that makes people think it's okay that my service was poor compared to my for-profit competitor's service because of this great feel-good social part. No, I want to compete on the merits of competition. So there's this nice social benefit, but do not use this in your calculus as a subsidy for choosing us over another firm, I don't want that. Because then we're not holding our people accountable for what they need to be accountable for. Because if I say, 'oh it's okay to only show up 4 days a week Mr. job-training poor guy, he's not getting what he needs out of this and if he goes to a regular job, he's not going to be able to cut it. I'm doing him a disservice. So, no - I'm going to be as hardnosed and cutthroat about this as I can. Yes, we're doing good things. But, I can't run the business that way.

In contrast, other social entrepreneurs explained that their economic message is of secondary emphasis. Informant_7, the founder of a faith-based social enterprise that helps low-income individuals start their own businesses, claims that for her venture the social message is preferred. In fact, it has been instrumental in attracting volunteers and employees.

[We] primarily emphasize the social good that we're doing. And I've been very fortunate where a lot of people have expressed interest in what we're doing. So I haven't had to go out, you know, looking too much. People have pretty much come to us... But at the end of the day it's really about the people that we're trying to touch through these different businesses or different solutions.

Finally, Informant_3 and Informant_2's viewpoints (below) are representative of those who argue that both messages should be developed and deployed based on the particular audience that is targeted.

What we've done is, both in the way we're developing the organizational structure, as well as the way we define success, we define success in two ways: are we transforming individuals' lives - and we have qualitative and quantitative metrics we're defining that by - and are we financially viable? Those two things can't be separated because if you're not financially viable, then you're going to have to be dependent upon donations. It's not sustainable.

I think that the answer to that question [Should you emphasize an economic or social message?] is actually all about the audience. It's just depends who you are pitching to, right? The reality is that social entrepreneurs customize that message to their audience. 


\section{Summary}

To summarize, although the sample size was limited and the analysis preliminary, pilot interviews provided evidence that the phenomenon of social enterprise resource acquisition could generate several, theoretically interesting questions. For instance, how do organizations use narratives and emotion to communicate with diverse groups of resource providers that value very different criteria? Moreover, there was also evidence that by studying social ventures we could gain a better understanding of how organizations with two dominant logics juggle communicating about those logics to stakeholder groups. Ultimately, the pilot study revealed that social enterprise was a phenomenon well-suited for uncovering new and unexpected theoretical insights. 
Appendix D:

Additional Tables

TABLE 14:

DESCRIPTION OF STUDY 1 INFORMANTS: FUNDERS

\begin{tabular}{|l|l|l|}
\hline \multicolumn{1}{|c|}{ Informant } & \multicolumn{1}{|c|}{ Type } & \multicolumn{1}{c|}{ Focus } \\
\hline Investor_1 & $\begin{array}{l}\text { Community } \\
\text { Development } \\
\text { Financial Institution }\end{array}$ & $\begin{array}{l}\text { Provides small } \\
\text { business loans, } \\
\text { assistance, and } \\
\text { education to } \\
\text { organizations with } \\
\text { limited access to } \\
\text { resources }\end{array}$ \\
\hline Investor_2 & Private Foundation & $\begin{array}{l}\text { Funding innovative } \\
\text { projects in health, } \\
\text { education, and } \\
\text { human services }\end{array}$ \\
\hline Investor_3 & Private Foundation & $\begin{array}{l}\text { Funding faith-based } \\
\text { and community } \\
\text { initiatives }\end{array}$ \\
\hline Investor_4 & Private Foundation & $\begin{array}{l}\text { Funding innovative } \\
\text { nonprofits and } \\
\text { schools }\end{array}$ \\
\hline Investor_5 & Private Foundation & $\begin{array}{l}\text { Foundation } \\
\text { managing smaller, } \\
\text { charitable funds }\end{array}$ \\
\hline Investor_6 & $\begin{array}{l}\text { Investment Rating } \\
\text { Firm }\end{array}$ & $\begin{array}{l}\text { Assesses investment } \\
\text { quality of social } \\
\text { enterprises }\end{array}$ \\
\hline
\end{tabular}


TABLE 14 (cont.)

\begin{tabular}{|c|c|c|}
\hline Investor_8 & Angel Network & $\begin{array}{l}\text { Traditional } \\
\text { investments }\end{array}$ \\
\hline Investor_9 & Angel Network & $\begin{array}{l}\text { Traditional } \\
\text { investments }\end{array}$ \\
\hline Investor_16 & Angel Network & $\begin{array}{l}\text { Traditional } \\
\text { investments }\end{array}$ \\
\hline Investor_10 & $\begin{array}{l}\text { Social-good } \\
\text { investment fund }\end{array}$ & $\begin{array}{l}\text { Early-stage impact } \\
\text { investing network }\end{array}$ \\
\hline Investor_11 & $\begin{array}{l}\text { Social-good } \\
\text { investment fund }\end{array}$ & $\begin{array}{l}\text { Impact investment } \\
\text { firm managing social } \\
\text { impact funds }\end{array}$ \\
\hline Investor_15 & $\begin{array}{l}\text { Social enterprise } \\
\text { investment fund }\end{array}$ & $\begin{array}{l}\text { Fund innovative } \\
\text { nonprofits }\end{array}$ \\
\hline Investor_17 & $\begin{array}{l}\text { Social enterprise } \\
\text { investment fund }\end{array}$ & $\begin{array}{l}\text { Non-profit and for- } \\
\text { profit social } \\
\text { enterprises } \\
\text { addressing key } \\
\text { issues in the areas of } \\
\text { Food \& Agriculture, } \\
\text { Education \& the } \\
\text { Arts, and Ecological } \\
\text { Stewardship. }\end{array}$ \\
\hline Investor_13 & $\begin{array}{l}\text { Social-good } \\
\text { investment } \\
\text { foundation }\end{array}$ & $\begin{array}{l}\text { Impact investing in } \\
\text { developing countries }\end{array}$ \\
\hline Investor_12 & $\begin{array}{l}\text { "Impact"-oriented } \\
\text { private equity firm }\end{array}$ & $\begin{array}{l}\text { For-profit companies } \\
\text { that emphasize } \\
\text { sustainability }\end{array}$ \\
\hline Investor_14 & $\begin{array}{l}\text { Philanthropic } \\
\text { investment fund }\end{array}$ & $\begin{array}{l}\text { Invest in innovative } \\
\text { nonprofits }\end{array}$ \\
\hline
\end{tabular}


TABLE 15:

DESCRIPTION OF STUDY 1 INFORMANTS: OTHER PARTICIPANTS IN THE SOCIAL ENTERPRISE SECTOR

\begin{tabular}{|c|c|c|}
\hline Informant & Position & Description \\
\hline Other_1 & Founder & $\begin{array}{l}\text { Video production } \\
\text { company; Targeting } \\
\text { nonprofits and social } \\
\text { enterprise }\end{array}$ \\
\hline Other_2 & Co-founder & $\begin{array}{l}\text { Office and } \\
\text { community space for } \\
\text { social entrepreneurs }\end{array}$ \\
\hline Other_3 & Editor / reporter & $\begin{array}{l}\text { Media outlet focused } \\
\text { on social enterprise }\end{array}$ \\
\hline Other_4 & Consultant & $\begin{array}{l}\text { Nonprofit consulting } \\
\text { center focused on } \\
\text { social enterprise }\end{array}$ \\
\hline Other_5 & Consultant; Director & $\begin{array}{l}\text { Nonprofit consulting } \\
\text { center focused on } \\
\text { social enterprise }\end{array}$ \\
\hline Other_6 & Attorney & $\begin{array}{l}\text { Specializing in } \\
\text { social enterprise law }\end{array}$ \\
\hline Other_7 & $\begin{array}{l}\text { Co-founder; } \\
\text { Consultant }\end{array}$ & $\begin{array}{l}\text { Social enterprise } \\
\text { consulting firm that } \\
\text { helps companies } \\
\text { adopt CSR } \\
\text { initiatives }\end{array}$ \\
\hline Other_8 & Consultant & $\begin{array}{l}\text { Consultant } \\
\text { specializing in social } \\
\text { enterprise financing }\end{array}$ \\
\hline
\end{tabular}




\section{Appendix E:}

\section{Interview Guide (Entrepreneur) and Consent Form}

Date:

Location:

Time: Begin:

End:

Interviewer:

Respondent:

Introduction (5 minutes)

1. Background of researcher

2. Research purpose: I am trying to understand how social entrepreneurs get the financial and non-financial resources they need to be successful

3. This research program consists of:

a. Interview (60-90 minutes)

b. Follow-up telephone / email conversations

Consent and Confidentiality ( 2 minutes)

1. Present and explain consent form (provided in Appendix E)

2. Offer and explain confidentiality / privacy protection procedures

Main Phase of Interview (45 minutes)

1. Background information

a. Can you describe your background and work experiences leading up to the founding of [social enterprise]?

i. What is your educational background?

ii. What is your prior work experience?

1. Do you have prior start-up / entrepreneurial experience? 
2. Have you founded any other social enterprises?

2. Venture founding

a. Can you describe the founding of [social enterprise]?

i. When was it founded?

ii. Who are the founders?

iii. What is your role in the company?

iv. Do you hold all of the equity?

3. Motivation for founding

a. Personal values / beliefs

b. Prior volunteer experiences

4. Background information about the social enterprise

a. Revenue (current and historical)?

b. Number of employees?

i. Paid?

ii. Volunteer?

iii. Social mission influenced ability to acquire employees?

c. Can you describe the business model?

i. Please describe your product / service.

ii. What social need do you address?

iii. Who are your customers?

iv. Who are your beneficiaries?

5. Organizational form / structure

a. Do you classify yourself / your venture as a "social entrepreneur" / "social enterprise"?

i. If so, how would you define a "social enterprise"? 
b. Can you describe your decision to form a social enterprise?

i. Did you consider forming as a traditional new venture?

c. What is your current organizational form (for-profit, nonprofit, hybrid)?

d. How did you decide to form as a for-profit, nonprofit, or hybrid?

e. Have you considered any of the new legal forms (e.g. flexible purpose corporation, L3C (Low profit limited liability corporation), benefit corporation)?

6. Resource acquisition / funding

a. Financial resources

i. How have you funded [social enterprise] to this point?

1. Early stages of the venture / seed funding:

a. Traditional sources - Have you used / pursued:

i. Bootstrapping?

ii. Angel?

iii. Venture capital?

b. "Social" funding sources:

i. Philanthropists?

ii. Private foundations?

iii. Grant-giving/fellowship organizations?

iv. Government?

v. Social venture capital?

2. Current financial funding

a. Sources?

b. Actions taken to acquire resources

i. Social networks 
1. Who are your board members?

2. What are their backgrounds?

3. How did they become board members?

4. Have they been involved with resource acquisition efforts, and if so, how?

5. Does the social venture belong to any industry associations?

6. Do you have any other partnerships with other organizations?

ii. Use of substantive and symbolic actions

1. Has your organization participated in any competitions or applied for/received any awards?"

c. Nonfinancial resources

1. Has your organization sought or received any media attention?

2. Have you taken any steps to establish/improve your reputation?

3. How have you found employees or volunteers?

d. Resource acquisition

i. Recent acquisition attempts

1. What resource acquisition / funding attempts have you made in the past 18 months?

ii. Future

1. What resource acquisition / funding attempts do you plan to make in the next 18 months? 


\section{e. Customers}

i. Have you found that your social focus has influenced your ability to acquire customers? How so?

7. When pitching your company to potential investors, customers, the media, etc., do you lead with your social or business message/narrative?

8. Do you capture the narratives of the social group you seek to benefit?

a. Include narratives on website?

b. Use narratives when communicating to resource providers?

9. What is the most significant problem you are facing right now?

a. (i.e. what is the challenge that keeps you up at night as an organizational leader)

10. Major milestones / goals for the next 6-12 months?

11. Anything else you wanted to talk about / tell me?

\section{Snowball Sampling}

1. Are there any other members of your organization that you suggest I speak with?

2. Are there any other social entrepreneurs that you recommend I speak with?

3. Is there anyone on the funding / resource provider-side that you recommend I speak with? 


\title{
Consent for Participation in Research
}

\author{
Title: Understanding Social Enterprise Funding
}

\section{Introduction}

The purpose of this form is to provide you information that may affect your decision as to whether or not to participate in this research study. The person performing the research will answer any of your questions. Read the information below and ask any questions you might have before deciding whether or not to take part. If you decide to be involved in this study, this form will be used to record your consent.

\section{Purpose of the Study}

The purpose of this study is to understand how social entrepreneurs obtain the financial and nonfinancial resources they need.

\section{What will you be asked to do?}

If you agree to participate in this study, you will be asked to

- Take part in one, 45-60 minute interview

This study will take 18 months and will include approximately 50 participants.

Your participation will be audio recorded.

\section{What are the risks involved in this study?}

The risks in this study are no greater than everyday life.

\section{What are the possible benefits of this study?}

The possible benefit of participation is that you may gain a better understanding of how to acquire resource for your venture.

Also, at the conclusion of the study you will receive a summary of the results.

\section{Do you have to participate?}

No, your participation is voluntary. You may decide not to participate at all or, if you start the study, you may withdraw at any time. Withdrawal or refusing to participate will not affect your relationship with The University of Texas at Austin (University) in anyway.

If you would like to participate, sign this form. You will receive a copy of this form.

\section{Will there be any compensation?}


You will not receive any type of payment for participating in this study.

\section{What are my confidentiality or privacy protections when participating in this research study?}

All information obtained from participants in this study will remain confidential. To maintain confidentiality, a pseudonym will be assigned to each participant. Any quotations used in publications resulting from the data will be attributed to the pseudonyms. Also, information provided in the interviews will not be divulged to others in ways that are inconsistent with the understanding of the original disclosure. Additionally, participants will be assured that anything disclosed in an interview will not be shared with any other study participant.

If you choose to participate in this study, you may choose to be audio recorded. Any audio

recordings will be stored securely and only the research team will have access to the

recordings. Recordings will be kept for 6 months and then erased. The data resulting from

your participation may be used for future research or be made available to other researchers

for research purposes not detailed within this consent form.

\section{Whom to contact with questions about the study?}

Prior, during or after your participation you can contact the researcher Philip T. Roundy at:

(XXX) XXX-XXXX or send an email to philip.roundy@phd.mccombs.utexas.edu. This study has been reviewed and approved by The University Institutional Review Board and the study number is 2011-09-0132

\section{Whom to contact with questions concerning your rights as a research participant?}

For questions about your rights or any dissatisfaction with any part of this study, you can contact, anonymously if you wish, the Institutional Review Board by phone at (512) 4718871 or email at orsc@uts.cc.utexas.edu.

\section{Signature}

You have been informed about this study's purpose, procedures, possible benefits and risks, and you have received a copy of this form. You have been given the opportunity to ask questions before you sign, and you have been told that you can ask other questions at any time. You voluntarily agree to participate in this study. By signing this form, you are not waiving any of your legal rights. 
I agree to be audio recorded

Printed Name

Signature

Date

As a representative of this study, I have explained the purpose, procedures, benefits, and the risks involved in this research study.

Print Name of Person obtaining consent

Signature of Person obtaining consent

Date 


\section{Bibliography}

Abolafia, M. Y. (2010). Narrative construction as sensemaking: How a Central Bank thinks. Organization Studies, 31(3), 349-367.

Aiman-Smith, L., Scullen, S. E., \& Barr, S. H. (2002). Conducting studies of decision making in organizational contexts: A tutorial for policy capturing and other regression-based techniques. Organizational Research Methods, 5, 388-414.

Alberto, M. (2011). Successful social entrepreneurship. from http://matthewalberto.com/2011/10/successful-social-entrepreneurship-2/

Aldrich, H., \& Auster, E. R. (1986). Even dwarfs started small: Liabilities of age and size and their strategic implications. Research in Organizational Behavior, 8, 165-198.

Aldrich, H. E., \& Fiol, C. M. (1994). Fools rush in? The institutional context of industry creation. Academy of Management Review, 19(4), 645-670.

Allen, M. W. (1992). Communication and organizational commitment: Perceived organizational support as a mediating factor. Communication Quarterly, 40(4), 357-367.

Allport, G. W. (1935). Attitudes. In A Handbook of Social Psychology (pp. 798-844). Worcester: Clark University Press.

Altman, R. (2008). A theory of narrative. New York: Columbia Univ Press.

Alvarez, S. A., \& Barney, J. B. (2007). Discovery and creation: Alternative theories of entrepreneurial action. Strategic Entrepreneurship Journal, 1(1-2), 11-26.

Alvord, S. H., Brown, L. D., \& Letts, C. W. (2004). Social Entrepreneurship and Societal Transformation. The Journal of Applied Behavioral Science, 40(3), 260-282.

Alwitt, L. F. (2002). Suspense and advertising responses. Journal of Consumer Psychology, 12(1), 35-49.

Amabile, T. M., Barsade, S. G., Mueller, J. S., \& Staw, B. M. (2005). Affect and creativity at work. Administrative Science Quarterly, 50(3), 367-403.

Amit, R., Brander, J., \& Zott, C. (1998). Why do venture capital firms exist? Theory and Canadian evidence. Journal of Business Venturing, 13(6), 441-466.

Amit, R., \& Schoemaker, P. J. H. (1993). Strategic assets and organizational rent. Strategic Management Journal, 14(1), 33-46. 
Andersen, P. H., \& Drejer, I. (2008). Systemic innovation in a distributed network: the case of Danish wind turbines, 1972â€’2007. Strategic Organization, 6(1), 13-46.

Andries, P. \& Debackere, K. (2006). Adaptation in new technology-based ventures: Insights at the company level. International Journal of Management Reviews, 8(2): 91-112.

Andringa, E. (1996). Effects of 'narrative distance' on readers' emotional involvement and response. Poetics, 23(6), 431-452.

Anonymous. (2009). The power of a well-told story. from http://www.socialedge.org/blogs/skoll-scholars-2009/the-power-of-a-well-toldstory

Appel, M., \& Richter, T. (2010). Transportation and Need for Affect in Narrative Persuasion: A Mediated Moderation Model. Media Psychology, 13(2), 101-135.

Arnold, M. B. (1960). Emotion and personality. Vol. I. Psychological aspects. New York: Columbia Univer. Press.

Ashforth, B. E., \& Humphrey, R. H. (1997). The Ubiquity and Potency of Labeling Organizations. Organization Science, 8(1), 43-58.

Auerswald, P. (2009). Creating social value. Stanford Social Innovation Review, 7(2), 5155.

Austin, J., Stevenson, H., \& Wei-Skillern, J. (2006). Social and Commercial Entrepreneurship: Same, Different, or Both? Entrepreneurship Theory and Practice, 30(1), 1-22.

Baesler, E. J. (1997). Persuasive effects of story and statistical evidence. Argumentation and Advocacy, 33(4), 170-175.

Baesler, E. J., \& Burgoon, J. K. (1994). The Temporal Effects of Story and Statistical Evidence on Belief Change. Communication Research 21(5), 582-602.

Baker, T., \& Nelson, R. E. (2005). Creating something from nothing: Resource construction through entrepreneurial bricolage. Administrative Science Quarterly, 50(3), 329-366.

Baktin, M. (1973). Problems of Dostoevsky's Poetics. In. Ann Arbor: Ardis. 
Bal, M. (1985). Introduction to the Theory of Narrative. Toronto: University of Toronto Press.

Bamberg, M. G. W. (1997). Positioning between structure and performance. Journal of Narrative and Life History, 7(1-4), 335-342.

Banister, P., Burman, E., Parker, I., Taylor, M., \& Tindall, C. (1995). Qualitative methods in psychology. Buckingham: Open University Press.

Bargh J. A. \& Chartrand, T. L. 1999. The unbearable automaticity of being. American Psychologist,54(7): 462-479.

Barney, J. (1991). Firm Resources and Sustained Competitive Advantage. Journal of Management, 17(1), 99-120.

Barney, J. B. (1986). Strategic factor markets: expectations, luck, and business strategy. Management Science, 32(10), 1231-1241.

Baron, D. P. (2007). Corporate Social Responsibility and Social Entrepreneurship. Journal of Economics \& Management Strategy, 16(3), 683-717.

Barringer, B. R., \& Harrison, J. S. (2000). Walking a Tightrope: Creating Value Through Interorganizational Relationships. Journal of Management, 26(3), 367-403.

Barry, D., \& Elmes, M. (1997). Strategy retold: Toward a narrative view of strategic discourse. Academy of Management Review, 22(2), 429-452.

Barsade, S. G. (2002). The ripple effect: Emotional contagion and its influence on group behavior. Administrative Science Quarterly, 47(4), 644-675.

Barsade, S. G., \& Gibson, D. E. (2007). Why does affect matter in organizations? Academy of Management Perspectives, 21(1), 36-59.

Bartel, C. A., \& Garud, R. (2009). The Role of Narratives in Sustaining Organizational Innovation. Organization Science, 20(1), 107-117.

Batra, R., \& Stayman, D. M. (1990). The role of mood in advertising effectiveness. Journal of Consumer Research, 203-214.

Battilana, J., \& Dorado, S. (2010). Building sustainable hybrid organizations: The case of commercial microfinance organizations. Academy of Management Journal, 53(6), 1419-1440.

Beal, D., \& Goyen, M. (1998). 'Putting your money where your mouth is' a profile of 
ethical investors. Financial Services Review, 7(2), 129-143.

Bianchi, A. (2005). I want you to meet Joe [Electronic Version]. Stanford Social Innovation Review, Spring, 60-63.

Black, J. B., \& Bern, H. (1981). Causal coherence and memory for events in narratives. Journal of Verbal Learning and Verbal Behavior, 20(3), 267-275.

Bode, C., Wagner, S. M., Petersen, K. J., \& Ellram, L. M. (2011). Understanding Responses to Supply Chain Disruptions: Insights from Information Processing and Resource Dependence Perspectives. Academy of Management Journal, 54(4), 833-856.

Bodenhausen, G. V., Sheppard, L. A., \& Kramer, G. P. (1994). Negative affect and social judgment: The differential impact of anger and sadness. European Journal of Social Psychology, 24(1), 45-62.

Boje, D. M. (1991). The storytelling organization: A study of story performance in an office-supply firm. Administrative Science Quarterly, 36(1), 106-126.

Boje, D. M. (1995). Stories of the storytelling organization: a postmodern analysis of Disney as" Tamara-Land". Academy of Management Journal, 38(4), 997-1035.

Bosma, N., \& Levie, J. (2010). Global entrepreneurship monitor 2009 executive report. London: Global Entrepreneurship Research Association.

Brewer, W. F., \& Lichtenstein, E. H. (1981). Event schemas, story schemas, and story grammars. In J. Long \& A. Baddeley (Eds.), Attention and performance IX. Hillsdale: Erlbaum.

Brewer, W. F., \& Lichtenstein, E. H. (1982). Stories are to entertain: A structural-affect theory of stories. Journal of Pragmatics, 6(5-6), 473-486.

Brewer, W. F., \& Nakamura, G. V. (1984). The nature and functions of schemas. In R. S. Wyer Jr. \& T. K. Srull (Eds.), Handbook of Social Cognition (Vol. 9, pp. 119160). Hillsdale: Erlbaum.

Brewster Boyd, N. H., Reyna, E., Wang, D. E., \& Welch, M. D. (2009). Hybrid Organizations. Austin: Greenleaf Publishing.

Bridgman, T., \& Barry, D. (2002). Regulation is evil: An application of narrative policy analysis to regulatory debate in New Zealand. Policy Sciences, 35(2), 141-161.

Brockmier, J., \& Harre, R. (1997). Narrative: Problems and Promises of an Alternative 
Paradigm. Research on Language \& Social Interaction, 30(4), 263-283.

Brouard, F., \& Larivet, S. (2010). In A. Fayolle \& H. Matlay (Eds.), Handbook on Research on Social Entrepreneurship (pp. 29-56). Cheltenham: Edward Elgar.

Brown, A. D. (1998). Narrative, Politics and Legitimacy in an IT Implimentation. Journal of Management Studies, 35(1), 35-58.

Brown, A. D. (2006). A Narrative Approach to Collective Identities*. Journal of Management Studies, 43(4), 731-753.

Brown, A. D., Humphreys, M., \& Gurney, P. M. (2005). Narrative, identity and change: a case study of Laskarina Holidays. Journal of Organizational Change Management, 18(4), 312-326.

Brown, A. D., Stacey, P., \& Nandhakumar, J. (2008). Making sense of sensemaking narratives. Human Relations, 61(8), 1035-1062.

Bruner, J. (1986). Actual minds, possible worlds. Cambridge: Harvard Univ Press.

Bruner, J. (1990). Acts of Meaning. Cambridge: Harvard University Press.

Bruner, J. (1991). The narrative construction of reality. Critical Inquiry, 18(1), 1-21.

Brush, C. G., Greene, P. G., Hart, M. M., \& Haller, H. S. (2001). From Initial Idea to Unique Advantage: The Entrepreneurial Challenge of Constructing a Resource Base [and Executive Commentary]. Academy of Management Executive, 15(1), 64-80.

Bruton, G. D., \& Rubanik, Y. (2002). Resources of the firm, Russian high-technology startups, and firm growth. 17(6), 553-576.

Bryant, M., \& Cox, J. W. (2004). Conversion stories as shifting narratives of organizational change. Journal of Organizational Change Management, 17(6), 578-592.

Buck, R., Anderson, E., Chaudhuri, A., \& Ray, I. (2004). Emotion and reason in persuasion: Applying the ARI model and the CASC Scale. Journal of Business Research, 57(6), 647-656.

Burke, K. (1969). A grammar of motives. Los Angeles: Univ of California Press.

Burns, T., \& Stalker, G. M. (1961). The Management of Innovation, Tavistock. London. 
Butler, J. S. (2004). The science and practice of new business ventures: Wealth creation and prosperity through entrepreneurship growth and renewal. In H. P. Welsch (Ed.), Entrepreneurship: The way ahead (pp. 42-54). New York: Routledge.

Cajaiba-Santana, G. (2011). Socially constructed opportunities in social entrepreneurship: A structuration model. In A. Fayolle \& H. Matlay (Eds.), Handbook of Research on Social Entrepreneurship (pp. 88-106). Cheltenham: Edward Elgar.

Caplan, R. D., \& Van Harrison, R. (1993). Person-Environment Fit Theory: Some History, Recent Developments, and Future Directions. Journal of Social Issues, 49(4), 253-275.

Cardon, M. S., \& Stevens, C. E. (2004). Managing human resources in small organizations: What do we know? Human Resource Management Review, 14(3), 295-323.

Cardon, M. S., Sudek, R., \& Mitteness, C. (2009). The impact of perceived entrepreneurial passion on angel investing. Frontiers in Entrepreneurship Research, 29(2): 1-15.

Cardon, M. S., Wincent, J., Singh, J., \& Drnovsek, M. 2009. The nature and experience of entrepreneurial passion. Academy of Management Review, 34(3): 511-532.

Carland, J. W., Hoy, F., Boulton, W. R., \& Carland, J. A. C. (1984). Differentiating entrepreneurs from small business owners: A conceptualization. Academy of Management Review, 9(2), 354-359.

Carroll, A. B. (1999). Corporate social responsibility. Business \& Society, 38(3), 268295.

Carroll, G. R., \& Hannan, M. T. (1989). Density delay in the evolution of organizational populations: A model and five empirical tests. Administrative Science Quarterly, 34(3), 411-430.

Certo, S. T. \& Hodge, F. 2007. Top management team prestige and organizational legitimacy: An examination of investor perceptions. Journal of Managerial Issues, 19(4): 461-477.

Casciaro, T., \& Piskorski, M. J. (2005). Power Imbalance, Mutual Dependence, and Constraint Absorption: A Closer Look at Resource Dependence Theory. Administrative Science Quarterly, 50(2), 167-199.

Cesario, J., Grant, H., \& Higgins, E. T. (2004). Regulatory fit and persuasion: Transfer from" feeling right." Journal of Personality and Social Psychology, 86(3), 388404. 
Chaiken, S., \& Eagly, A. H. (1989). Heuristic and Systematic Information Processing within and. In J. S. Uleman \& J. A. Bargh (Eds.), Unintended Thought (Vol. 212, pp. 212-252). New York: The Guilford Press.

Chang, C. (2009). "Being Hooked" By Editorial Content: The Implications for Processing Narrative Advertising. Journal of Advertising, 38(1), 21-34.

Chatman, S. B. (1980). Story and discourse: Narrative structure in fiction and film. Ithaca: Cornell Univ Press.

Chen, S., \& Chaiken, S. (1999). The heuristic-systematic model in its broader context. In S. Chaiken \& Y. Trope (Eds.), Dual-process theories in social psychology (pp. 73-96). New York: The Guilford Press.

Clark, M. S., \& Isen, A. M. (1982). Toward understanding the relationship between feeling states and social behavior. In A. H. Hastorf \& A. M. Isen (Eds.), Cognitive Social Psychology (pp. 73-108). New York: Elsevier/North-Holland.

Clatworthy, M., \& Jones, M. J. (2001). The effect of thematic structure on the variability of annual report readability. Accounting, Auditing, \& Accountability Journal, 14(3), 311-326.

Cohen, L. \& Mallon, M. 2001. My brilliant career? Using stories as a methodological tool in careers research. International Studies of Management and Organization, 31(3): 48-68.

Conlon, D. E., \& Garland, H. (1993). The role of project completion information in resource allocation decisions. Academy of Management Journal, 36(2), 402-413.

Connelly, F. M., \& Clandinin, D. J. (1990). Stories of experience and narrative inquiry. Educational Researcher, 19(5), 2-14.

Coplan, A. (2004). Empathic engagement with narrative fictions. The Journal of Aesthetics and Art Criticism, 62(2), 141-152.

Corley, K. G., \& Gioia, D. A. (2004). Identity ambiguity and change in the wake of a corporate spin-off. Administrative Science Quarterly, 49(2), 173-208.

Corner, P. D., \& Ho, M. (2010). How Opportunities Develop in Social Entrepreneurship. Entrepreneurship Theory and Practice, 34(4), 635-659.

Cortazzi, M. (1993). Narrative analysis (Vol. 12). London: Routledge. 
Crook, T. R., Ketchen, D. J., Combs, J. G., \& Todd, S. Y. (2008). Strategic resources and performance: a meta-analysis. Strategic Management Journal, 29(11), 1141-1154.

Cunliffe, A.L., Luhman, J. T., Boje, D. M. (2004). Narrative temporality: Implications for organizational research. Organization Studies, 25(2): 261-286.

Cupchik, G. C., Oatley, K., \& Vorderer, P. (1998). Emotional effects of reading excerpts from short stories by James Joyce. Poetics, 25(6), 363-377.

Czarniawska-Joerges, B. (1997). Narrating the organization: Dramas of institutional identity. Chicago: University of Chicago Press.

Czarniawski, B. (1998). A Narrative Approach to Organization Studies. London: Sage.

Dacin, M. T., Dacin, P. A., \& Tracey, P. (2011). Social entrepreneurship: A critique and future directions. Organization Science, 22(5), 1203-1213.

Dart, R. (2004). The legitimacy of social enterprise. Nonprofit Management and Leadership, 14(4), 411-424.

Das, T. K., \& Teng, B. S. (2000). A resource-based theory of strategic alliances. Journal of Management, 26(1), 31-61.

Davila, A., Foster, G., \& Gupta, M. (2003). Venture capital financing and the growth of startup firms. Journal of Business Venturing, 18(6), 689-708.

Dees, J. G. (1998). The meaning of social entrepreneurship. Working Paper: Stanford University.

Dees, J. G., Emerson, J., \& Economy, P. (2001). Enterprising nonprofits: A toolkit for social entrepreneurs (Vol. 159). New York: John Wiley \& Sons Inc.

Deetz, S. (1992). Democracy in an Age of Corporate Colonization: Developments in Communication and the Politics of Everyday Life. Albany: State University of New York Press.

Delmar, F., \& Shane, S. (2003). Does business planning facilitate the development of new ventures? Strategic Management Journal, 24(12), 1165-1185.

Delmar, F., \& Shane, S. (2004). Legitimating first: organizing activities and the survival of new ventures. Journal of Business Venturing, 19(3), 385-410.

Derwall, J., Koedijk, K., \& Ter Horst, J. (2011). A tale of values-driven and profitseeking social investors. Journal of Banking and Finance, 35(8), 2137-2147. 
DeSteno, D., Petty, R. E., Rucker, D. D., Wegener, D. T., \& Braverman, J. (2004). Discrete emotions and persuasion: the role of emotion-induced expectancies. Journal of Personality and Social Psychology, 86(1), 43-56.

Dierickx, I., \& Cool, K. (1989). Asset stock accumulation and sustainability of competitive advantage. Management Science, 35(12), 1504-1511.

Dijkstra, K., Zwaan, R. A., Graesser, A. C., \& Magliano, J. P. (1995). Character and reader emotions in literary texts. Poetics, 23(1-2), 139-157.

Dillard, J. P., \& Peck, E. (2000). Affect and Persuasion. Communication Research, 27(4), 461-495.

Dorado, S. (2006). Social entrepreneurial ventures: different values so different process of creation, no? Journal of Developmental Entrepreneurship, 11(4), 319.

Downing, S. (2005). The Social Construction of Entrepreneurship: Narrative and Dramatic Processes in the Coproduction of Organizations and Identities. Entrepreneurship Theory and Practice, 29(2), 185-204.

Duncan, R. B. (1972). Characteristics of organizational environments and perceived environmental uncertainty. Administrative Science Quarterly, 17(3), 313-327.

Dunford, R., \& Jones, D. (2000). Narrative in strategic change. Human Relations, 53(9), 1207-1226.

Dunlop, S., Wakefield, M., \& Kashima, Y. (2008). Can you feel it? Negative emotion, risk, and narrative in health communication. Media Psychology, 11(1), 52-75.

Dyer, M. G. (1983). In-depth understanding: A computer model of integrated processing for narrative comprehension. Cambridge: MIT press.

Eagly, A. H., \& Chaiken, S. (1993). The psychology of attitudes. Orlando: Harcourt Brace Jovanovich College Publishers.

Edmunds, A., \& Morris, A. (2000). The problem of information overload in business organisations: a review of the literature. International Journal of Information Management, 20(1), 17-28.

Eisenberg, N., \& Strayer, J. (1987). Critical issues in the study of empathy. In N. Eisenberg \& J. Strayer (Eds.), Empathy and its development. Cambridge studies in social and emotional development (pp. 3-13). New York: Cambridge University Press. 
Eisenhardt, K. M. (1989). Making fast strategic decisions in high-velocity environments. Academy of Management Journal, 32(3), 543-576.

Eisenhardt, K. M., \& Graebner, M. E. (2007). Theory building from cases: Opportunities and challenges. Academy of Management Journal, 50(1), 25-32.

Eisenhardt, K. M., \& Schoonhoven, C. B. (1990). Organizational growth: Linking founding team, strategy, environment, and growth among US semiconductor ventures, 1978-1988. Administrative Science Quarterly, 35, 504-529.

Eisenhardt, K. M., \& Schoonhoven, C. B. (1996). Resource-based view of strategic alliance formation: Strategic and social effects in entrepreneurial firms. Organization Science, 7(2), 136-150.

Ekman, P. (1992). An argument for basic emotions. Cognition and Emotion, 6(3-4), 169200.

Elaine, M. (1993). A resource-based perspective on the dynamic strategy-performance relationship: An empirical examination of the focus and differentiation strategies in. Journal of Management, 19(4), 819-839.

Elfenbein, H. A. (2007). Emotion in Organizations. Academy of Management Annals, 1(1), 315-386.

Ellis, R. D. (2005). Curious emotions: Experiencing and the Creation of Meaning. Amsterdam: Benjamins.

Elsbach, K. D. (1994). Managing organizational legitimacy in the California cattle industry: The construction and effectiveness of verbal accounts. Administrative Science Quarterly, 39, 57-88.

Elsbach, K. D., \& Barr, P. S. (1999). The effects of mood on individuals' use of structured decision protocols. Organization Science, 10(2), 181-198.

Engel, D. \& Keilbach, M. (2007). Firm-level implications of early stage venture capital investment - An empirical investigation. Journal of Empirical Finance, 14(2): 150-167.

Enkin, M. W., \& Jadad, A. R. (1998). Using anecdotal information in evidence-based health care: Heresy or necessity? Annals of Oncology, 9(9), 963-966.

Epstein, S. (1991). Cognitive-experiential self-theory: An integrative theory of personality. In R. C. Curtis (Ed.), The Relational Self: Theoretical Convergences in Psychoanalysis \& Social Pscyhology (pp. 111-137). New York: The Guilford Press. 
Epstein, S. (1994). Integration of the cognitive and the psychodynamic unconscious. American Psychologist, 49(8), 709-724.

Escalas, J. E. (2004b). Imagine yourself in the product: Mental simulation, narrative transportation, and persuasion. Journal of Advertising, 33(2), 37-48.

Escalas, J. E. (2004a). Narrative processing: Building consumer connections to brands. Journal of Consumer Psychology, 14(1-2), 168-180.

Escalas, J. E. (2007). Self-Referencing and Persuasion: Narrative Transportation versus Analytical Elaboration. Journal of Consumer Research, 33(4), 421-429.

Escalas, J. E., Moore, M. C., \& Britton, J. E. (2004). Fishing for feelings? Hooking viewers helps. Journal of Consumer Research, 14(1-2), 105-114.

Escalas, J. E., \& Stern, B. B. (2003). Sympathy and empathy: Emotional responses to advertising dramas. Journal of Consumer Research, 29(4), 566-578.

Evans, J. S. B. T. (2008). Dual-processing accounts of reasoning, judgment, and social cognition. Annual Review of Psychology, 59, 255-278.

Fayolle, A., \& Matlay, H. (2010). Social entrepreneurship: a multicultural and multidimensional perspective. In A. Fayolle \& H. Matlay (Eds.), Handbook of Research on Social Entrepreneurship (pp. 1-14). Cheltenham: Edward Elgar

Feldman-Barrett, L., \& Russell, J. A. (1998). Independence and bipolarity in the structure of affect. Journal of Personality and Social Psychology, 74, 967-984.

Fiese, B. H., Marjinsky, K., \& Cowan, P. A. (1999). The stories that families tell: Narrative coherence, narrative interaction, and relationship beliefs. Oxford: Wiley-Blackwell.

Fisher, W. R. (1985). The narrative paradigm: An elaboration. Communication Monographs, 52(4), 347-367.

Fiske, S. T., \& Linville, P. W. (1980). What does the schema concept buy us? Personality and Social Psychology Bulletin, 6(4), 543-557.

Florin, J., Lubatkin, M., \& Schulze, W. (2003). A social capital model of high-growth ventures. Academy of Management Journal, 46(3), 374-384.

Fombrun, C., \& Shanley, M. (1990). What's in a name? Reputation building and corporate strategy. Academy of Management Journal, 33(2), 233-258. 
Forster, E. M. (1985). Aspects of the Novel. Orlando: Mariner Books.

Forum, S. W. (2009). Winning Hearts And Minds: The Power Of A Well-Told Story.

Francis, L. E. (1994). Laughter, the best mediation: Humor as emotion management in interaction. Symbolic Interaction, 17(2), 147-163.

Frijda, N. H. (1986). The Emotions. London: Cambridge University Press.

Frijda, N. H. (1993). Moods, emotion episodes, and emotions. In Handbook of Emotions (pp. 381-403). New York: Guilford Press.

Fruchterman, J. (2011). For love or lucre. Stanford Social Innovation Review, Spring, 4247.

Galunic, D. C., \& Eisenhardt, K. M. (1994). Renewing the strategy-structureperformance paradigm (Vol. 16, pp. 215-255).

Garud, R., Dunbar, R. L. M., \& Bartel, C. A. (2011). Dealing with Unusual Experiences: A Narrative Perspective on Organizational Learning. Organization Science, 22(3), 587-601.

Georgesen, J.C. \& Solano, C. H. 1999. The effects of motivation on narrative content and structure. Journal of Language and Social Psychology 18(6): 175-194.

Gerrig, R. J. (1993). Experiencing narrative worlds: On the psychological activities of reading. Danbury: Yale Univ Pr.

Glaser, B., \& Strauss, A. (1967). The Discovery of Grounded Theory. Hawthorne: Aldine Publishing Company.

Goetz, E. T., Sadoski, M., Stowe, M. L., Fetsco, T. G., \& Kemp, S. G. (1993). Imagery and emotional response in reading literary text. Poetics, 22, 35-49.

Golant, B. D., \& Sillince, J. A. A. (2007). The constitution of organizational legitimacy: A narrative perspective. Organization Studies, 28(8), 1149-1167.

Golding, D., Krimsky, S., \& Plough, A. (1992). Evaluating Risk Communication: Narrative vs. Technical Presentations of Information About Radon. Risk Analysis, 12(1), 27-35.

Goldman, P. (2008). Storytelling and social change [Electronic Version]. Social Edge from http://www.socialedge.org/discussions/marketing- 
communication/storytelling-and-social-change.

Graesser, A. C., Golding, J. M., \& Long, D. L. (1996). Narrative representation and comprehension. In R. Barr \& M. L. Kamil (Eds.), Handbook of reading research (pp. 171-205). Hillsdale, NJ: Erlbaum.

Grandey, A. A. (2000). Emotional regulation in the workplace: A new way to conceptualize emotional labor. Journal of Occupational Health Psychology, 5(1), 95-110.

Green, M. C. (2006). Narratives and cancer communication. Journal of Communication, $56,163-183$.

Green, M. C. (2008). Research challenges in narrative persuasion. Information Design Journal, 16(1), 47-52.

Green, M. C., \& Brock, T. C. (2000). The role of transportation in the persuasiveness of public narratives. Journal of Personality and Social Psychology, 79(5), 701-721.

Green, M. C., Brock, T. C., \& Kaufman, G. F. (2004). Understanding Media Enjoyment: The Role of Transportation Into Narrative Worlds. Communication Theory, 14(4), 311-327.

Greene, K., \& Brinn, L. S. (2003). Messages Influencing College Women's Tanning Bed Use: Statistical versus Narrative Evidence Format and a Self-Assessment to Increase Perceived Susceptibility. Journal of Health Communication, 8(5), 443461.

Greenhalgh, T. (1999). Narrative based medicine in an evidence based world. British Medical Journal, 318(7179), 323-325.

Greve, H. R. (2011). Positional rigidity: low performance and resource acquisition in large and small firms. Strategic Management Journal, 32(1), 103-114.

Griskevicius, V., Goldstein, N. J., Mortensen, C. R., Sundie, J. M., Cialdini, R. B., \& Kenrick, D. T. (2009). Fear and loving in Las Vegas: Evolution, emotion, and persuasion. Journal of Marketing Research, 46(3), 384-395.

Gulati, R. (1995). Does familiarity breed trust? The implications of repeated ties for contractual choice in alliances. Academy of Management Journal, 38(1), 85-112.

Gulati, R. (1998). Alliances and networks. Strategic Management Journal, 19(4), 293317. 
Gulati, R., \& Sytch, M. (2007). Dependence Asymmetry and Joint Dependence in Interorganizational Relationships: Effects of Embeddedness on a Manufacturer's Performance in Procurement Relationships. Administrative Science Quarterly, 52(1), 32-69.

Gupta, A. K., \& Govindarajan, V. (1986). Resource sharing among SBUs: Strategic antecedents and administrative implications. Academy of Management Journal, 29(4), 695-714.

Hagedoorn, J. (1993). Understanding the rationale of strategic technology partnering: Nterorganizational modes of cooperation and sectoral differences. Strategic Management Journal, 14(5), 371-385.

Hall, A. (2003). Reading Realism: Audiences' Evaluations of the Reality of Media Texts. Journal of Communication, 53(4), 624-641.

Hallen, B. L. (2008). The causes and consequences of the initial network positions of new organizations: From whom do entrepreneurs receive investments? Administrative Science Quarterly, 53(4), 685.

Hallen, B. L. \& Eisenhardt, K. M. (2012). Catalyzing strategies and efficient tie formation: How entrepreneurial firms obtain investment ties. Academy of Management Journal, 55 (1), 35-70.

Hannan, M. T., \& Freeman, J. (1977). The Population Ecology of Organizations. American Journal of Sociology, 82(5), 929-964.

Harrasser, K. (2002). Transforming discourse into practice: Computerhystories and digital cultures around 1984. Cultural Studies, 16(6), 820-832.

Harre, R. (2008). The discursive turn in social psychology. In D. Schiffrin, D. Tannen \& H. E. Hamilton (Eds.), The Handbook of Discourse Analysis (pp. 688-706). Massachusetts: Blackwell Publishers Ltd.

Heil, D., \& Whittaker, L. (2007). An ontological foundation for strategic management research: The role of narrative. Research Methodology in Strategy and Management, 4, 369-397.

Hellmann, T. (2002). A theory of strategic venture investing. Journal of Finance, 64(2), 285-314.

Herman, D. (2003). Narrative theory and the cognitive sciences. Stanford: Center for the Study of Language and Information. 
Herman, D. (2007). The Cambridge companion to narrative. New York: Cambridge Univ Press.

Herman, D., \& Ebrary, I. (2009). Basic elements of narrative. Oxford: Wiley-Blackwell.

Herman, D., Jahn, M., \& Ryan, M. L. (2005). Routledge encyclopedia of narrative theory. New York: Taylor and Francis.

Hervieux, C., \& Turcotte, M. F. (2010). Social entrepreneurs' actions in networks. In A. Fayolle \& H. Matlay (Eds.), Handbook of Research on Social Entrepreneurship (pp. 182-204). Cheltenham: Edward Elgar.

Herz, S., \& Mertes, C. (2008). Stories of change [Electronic Version]. Social Edge from http://www.socialedge.org/features/discussions/marketing-communication/storiesof-change/.

Hidi, S., \& Baird, W. (1986). Interestingness: A neglected variable in discourse processing. Cognitive Science, 10(2), 179-194.

Hidi, S., Baird, W., \& Hildyard, A. (1982). That's Important But is it Interesting? Two Factors in Text Processing. In Advances in Psychology (Vol. Volume 8, pp. 6375): North-Holland.

Hitt, M. A., Ahlstrom, D., Dacin, M. T., Levitas, E., \& Svobodina, L. (2004). The institutional effects on strategic alliance partner selection in transition economies: China vs. Russia. Organization Science, 15(2), 173-185.

Hoeken, H., \& van Vliet, M. (2000). Suspense, curiosity, and surprise: How discourse structure influences the affective and cognitive processing of a story. Poetics, 27(4), 277-286.

Hogan, P. C. (2003). The mind and its stories: narrative universals and human emotion. New York: Cambridge Univ Press.

Holloway, I., \& Todres, L. (2003). The Status of Method: Flexibility, Consistency and Coherence. Qualitative Research, 3(3), 345-357.

Holloway, I., \& Todres, L. (2003). The status of method: flexibility, consistency and coherence. Qualitative Research, 3(3), 345-357.

Hoshmand, L. T. (2005). Narratology, Cultural Psychology, and Counseling Research. Journal of Counseling Psychology, 52(2), 178.

Hsu, D. H. (2004). Why do entrepreneurs pay for venture capital affiliation. Journal of 
Finance, 59(4): 1804-1844.

Huber, G. P., \& Power, D. J. (1985). Retrospective reports of strategic-level managers: Guidelines for increasing their accuracy. Strategic Management Journal, 6(2), 171-180.

Huberman, A. M., \& Miles, M. B. (2002). The qualitative researcher's companion. Thousand Oaks: Sage Publications, Inc.

Humphreys, M., \& Brown, A. D. (2002). Narratives of organizational identity and identification: A case study of hegemony and resistance. Organization Studies, 23(3), 421-447.

Ibarra, H., \& Barbulescu, R. (2010). Identity as narrative: prevalence, effectiveness, and consequences of narrative identity work in macro work role transitions. Academy of Management Review, 35(1), 135-154.

Isen, A. M. (1987). Positive affect, cognitive processes, and social behavior. In L. Berkowitz (Ed.), Advances in Experimental Social Psychology (pp. 203-253).

Isen, A. M. (1993). Positive affect and decision making. In J. M. Haviland (Ed.), Handbook of emotions (pp. 261-277). New York: Guilford Press.

Jameson, F. (1981). The Political Unconscious: Narrative as a Socially Symbolic Act Ithaca: Methuen \& Co. Ltd.

Jarillo, C. (1989). Entrepreneurship and growth: the strategic use of external resources. Journal of Business Venturing, 4(2), 133-147.

Johnson, M. K., Hashtroudi, S., \& Lindsay, D. S. (1993). Source monitoring. Psychological Bulletin, 114(1), 3-28.

Jones, R., Latham, J., \& Betta, M. (2008). Narrative construction of the social entrepreneurial identity. International Journal of Entrepreneurial Behavior and Research, 14(5), 330-345.

Josselson, R. E., \& Lieblich, A. E. (1993). The narrative study of lives, Vol. 1. Thousand Oaks: Sage Publications, Inc.

Judge, T. A., \& Bretz, R. D. (1992). Effects of work values on job choice decisions. Journal of Applied Pscyhology, 77(3), 261.

Kahneman, D., \& Frederick, S. (2002). Representativeness revisited: Attribute substitution in intuitive judgment. In T. Gilovic, D. Griffin \& M. L. Kamil (Eds.), 
Heuristics and biases: The psychology of intuitive judgment (pp. 49-81). New York: Cambridge University Press.

Kazoleas, D. C. (1993). A comparison of the persuasive effectiveness of qualitative versus quantitative evidence: A test of explanatory hypotheses. Communication Quarterly, 41(1), 40-50.

Keen, S. (2006). A theory of narrative empathy. Narrative, 14(3), 207-236.

Kim, P., Perreault, G. \& Foster, W. (2011). Finding your funding model. Stanford Social Innovation Review, Fall: 37-42

Klaassen, D. W. \& McDonald, M. J. 2002. Quest and identity development: Reexamining pathways for existential search. International Journal for the Psychology of Religion 12(3): 189-200.

Kneepkens, E. W. E. M., \& Zwaan, R. A. (1995). Emotions and literary text comprehension. Poetics, 23(1-2), 125-138.

Kopfman, J. E., Smith, S. W., Yun, J. K. A., \& Hodges, A. (1998). Affective and cognitive reactions to narrative versus statistical evidence organ donation messages. Journal of Applied Communication Research, 26(3), 279-300.

Korosec, R. L., \& Berman, E. M. (2006). Municipal Support for Social Entrepreneurship. Public Administration Review, 66(3), 448-462.

Kreuter, M. W., Green, M. C., Cappella, J. N., Slater, M. D., Wise, M. E., Storey, D., et al. (2007). Narrative communication in cancer prevention and control: a framework to guide research and application. Annals of Behavioral Medicine, $33(3), 221-235$.

Kuhn, T. S. (1970). The Structure of Scientific Revoluations. Chicago: University of Chicago Press.

Labov, W. 1972. Language in the Inner City. Philadelphia, PA: Univ. of Pennsylvania Press.

Landa, J. A. G., \& Onega, S. (1999). Narratology: an introduction. London and New York: Longman.

Landstrom, H., \& Winborg, J. (2000). Financial Bootstrapping In Small Business: Examining Business Managersâ€ $€^{\mathrm{TM}}$ Resource Behaviors. Journal of Business Venturing, 16, 235-254. 
Langley, A. (1999). Strategies for theorizing from process data. Academy of Management Journal, 24(4), 691-710.

Larsen, S. F., \& László, J. (1990). Cultural-historical knowledge and personal experience in appreciation of literature. European Journal of Social Psychology, 20(5), 425440.

Lau-Gesk, L., \& Meyers-Levy, J. (2009). Emotional persuasion: When the valence versus the resource demands of emotions influence consumers' attitudes. Journal of Communication Research, 36(4), 585-599.

Leahy, G., \& Villaneuve-Smith, F. (2009). State of Social Enterprise Survey. London: Social Enterprise Coalition.

Leerssen, J. T. (1991). Mimesis and stereotype. Yearbook of European Studies, 4, 165175.

Leonardi, P. M., \& Jackson, M. H. (2004). Technological determinism and discursive closure in organizational mergers. Journal of Organizational Change Management, 17(6), 615-631.

Lepoutre, J., Justo, R., Terjesen, S., \& Bosma, N. (2010). Designing a Global Standardized Methodology for Measuring Social Entrepreneurship. London: Global Entrepreneurship Research Association.

Light, P. (2009). Searching for Social Entrepreneurs: Who they might be, where they might be found, what they do. In R. Mosher-Williams (Ed.), Research on social entrepreneurship: Understanding and contributing to an emerging field: Amova's Occasional Paper Series (pp. 13-37). Washington: Association for Research on Nonprofit and Voluntary Organizations.

Locke, K. (2001). Grounded Theory in Management Research. London: Sage.

Lounsbury, M., \& Glynn, M. A. (2001). Cultural entrepreneurship: stories, legitimacy, and the acquisition of resources. Strategic Management Journal, 22(6-7), 545564.

Lutz, C. A., \& Abu-Lughod, L. (1990). Language and the politics of emotion. Studies in emotion and social interaction. New York: Cambridge University Press.

Lyotard, J. F. (1984). The postmodern condition: A report on knowledge Minneapolis: Univ Of Minnesota Press.

MacIntyre, A. C. (1984). After virtue. Notre Dame: University of Notre Dame Press 
Mackie, D. M., \& Worth, L. T. (1989). Processing deficits and the mediation of positive affect in persuasion. Journal of Personality and Social Psychology, 57(1), 27-40.

MacMillan, I. C., Siegel, R., \& Narasimha, P. N. (1985). Criteria used by venture capitalists to evaluate new venture proposals. Journal of Business Venturing, 1(1), 119-128.

Macsai, D. (2008, September 8). The push to do good and turn a profit. Business Week. Retrieved from http://www.businessweek.com.

Madill, J. J., Haines, G. H., \& Riding, A. L. (2005). The role of angels in technology SMEs: A link to venture capital. Venture Capital: An International Journal of Entrepreneurial Finance, 7(2): 107-129.

Madlock, P. E. (2008). The link between leadership style, communicator competence, and employee satisfaction. 45(1), 61.

Mair, J. (2010). Social entrepreneurship: Taking stock and looking ahead. . In A. Fayolle \& H. Matlay (Eds.), Handbook fo Research on Social Entrepreneurship (pp. 1528). Cheltenham: Edward Elgar.

Mair, J., \& Marti, I. (2006). Social entrepreneurship research: A source of explanation, prediction, and delight. Journal of World Business, 41(1), 36-44.

Maitlis, S., \& Ozcelik, H. (2004). Toxic decision processes: A study of emotion and organizational decision making. Organization Science, 15(4), 375-393.

Malesh, P. M. (2009). Sharing Our Recipes: Vegan Conversion Narratives as Social Praxis. In S. M. Stevens \& P. M. Malesh (Eds.), Active Voices: Composing a Rhetoric for Social Movements (pp. 131-148). Albany: State University of New York Press.

Mano, H. (1992). Judgments under distress: Assessing the role of unpleasantness and arousal in judgment formation. Organizational Behavior and Human Decision Processes, 52(2), 216-245.

Mano, H. (1997). Affect and persuasion: The influence of pleasantness and arousal on attitude formation and message elaboration. Psychology and Marketing, 14(4), 315-335.

Margolis, M. J. (2007). Strategic storytelling and social innovation [Electronic Version]. Social Edge from http://www.socialedge.org/discussions/marketingcommunication/strategic-storytelling-and-social-innovation. 
Marino, C. (2010). Social enterprises as narratives of change [Electronic Version]. Global Social Entrepreneurship (Wooster College) from http://global_se.scotblogs.wooster.edu/2010/06/25/social-enterprises-asnarratives-of-change/.

Marquis, C., \& Lounsbury, M. (2007). Vive la resistance: Competing logics and the consolidation of US community banking. Academy of Management Journal, 50(4), 799-820.

Martens, M. L., Jennings, J. E., \& Jennings, P. D. (2007). Do the stories they tell get them the money they need? The role of entrepreneurial narratives in resource acquisition. Academy of Management Journal, 50(5), 1107-1132.

Martin, J., Feldman, M. S., Hatch, M. J., \& Sitkin, S. B. (1983). The uniqueness paradox in organizational stories. Adminstrative Sciene Quarterly, 28(3), 438-453.

Martin, R. L., \& Osberg, S. (2007). Social entrepreneurship: the case for definition. Stanford Social Innovation Review, 5(2), 28-39.

Mattila, A. S. (2000). The role of narratives in the advertising of experiential services. Journal of Service Research, 3(1), 35-45.

Mattila, A. S. (2002). The use of narrative appeals in promoting restaurant experiences. Journal of Hospitality and Tourism Research, 26(4), 379-395.

Maynard, D. W. (1988). Narratives and narrative structure in plea bargaining. Law and Society Review, 22(3), 449-481.

Mazzocco, P. J., Green, M. C., \& Brock, T. C. (2007). The effects of a prior story-bank on the processing of a related narrative. Media Psychology, 10(1), 64-90.

McAdams, D. P. 2008. Personal narratives and the life story. In John, O.P., Robins, R. W., \& Pervin, L. A. Handbook of Personality: Theory and Research (pp. 241261). New York: Guilford Press.

McAdams, D. P., Josselson, R. E., \& Lieblich, A. E. (2006). Identity and story: Creating self in narrative. Washington: American Psychological Association.

McCabe, A., \& Peterson, C. (1990). What makes a narrative memorable. Applied Psycholinguistics, 11(1), 73-82.

McComas, K., \& Shanahan, J. (1999). Telling Stories About Global Climate Change. Communication Research, 26(1), 30-57. 
McGuire, W. J. (1969). The nature of attitudes and attitude change. In The Handbook of Social Psychology (Vol. 3, pp. 136-314). Reading: Addison-Wesley

Meglino, B. M., \& Ravlin, E. C. (1998). Individual Values in Organizations: Concepts, Controversies, and Research. Journal of Management, 24(3), 351-389.

Merton, R. K. (1938). Social structure and anomie. American Sociological Review. 3(5): 672-682.

Miall, D. S. (1986). Emotion and self: The context of remembering. British Journal of Psychology, 77, 389-397.

Miall, D. S. (1988). Affect and narrative: A model of response to stories. Poetics, 17(3), 259-272.

Miall, D. S., \& Kuiken, D. (1994). Foregrounding, defamiliarization, and affect: Response to literary stories. Poetics, 22(5), 389-407.

Miceli, M., de Rosis, F., \& Poggi, I. (2006). Emotional and non-emotional persuasion. Applied Artificial Intelligence, 20(10), 849-879.

Miles, M. B. \& Huberman, A. M. (1994). Qualitative Data Analysis: An Expanded Sourcebook. Thousand Oaks, CA: Sage.

Miller, T. L., \& Wesley II, C. L. (2010). Assessing Mission and Resources for Social Change: An Organizational Identity Perspective on Social Venture Capitalists' Decision Criteria. Entrepreneurship Theory and Practice, 34(4), 705-733.

Minsky, M. (1975). A framework for representing knowledge. In P. H. Winston (Ed.), The psychology of computer vision. New York: McGraw-Hill.

Mohr, J., \& Spekman, R. (1994). Characteristics of partnership success: Partnership attributes, communication behavior, and conflict resolution techniques. Strategic Management Journal, 15(2), 135-152.

Mohr, L. B. (1982). Explaining Organizational Behavior. San Francisco: Jossey, Bass.

Mooney, L. A., \& David Knox, D. (2000). Understanding Social Problems. Belmont: Wadsworth.

Moore, M. (2011). Don't be a half-wit [Electronic Version]. Social Edge from http://www.socialedge.org/discussions/social-entrepreneurship/dont-be-a-half-wit.

Morgan, S. E., Cole, H. P., Struttmann, T., \& Piercy, L. (2002). Stories or statistics? 
Farmers' attitudes toward messages in an agricultural safety campaign. Journal of Agricultural Safety and Health, 8(2), 225-239.

Morris, J. A., \& Feldman, D. C. (1996). The dimensions, antecedents, and consequences of emotional labor. Academy of Management Review, 21(4), 986-1010.

Morris, M. Schindehutte, M., \& Allen, J. 2005. The entrepreneur's business model: Toward a unified perspective. Journal of Business Research. 58(6), 726-735.

Mort, G. S., Weerawardena, J., \& Carnegie, K. (2003). Social entrepreneurship: Towards conceptualisation. International Journal of Nonprofit and Voluntary Sector Marketing, 8(1), 76-88.

Moyer-Gusé, E. (2008). Toward a Theory of Entertainment Persuasion: Explaining the Persuasive Effects of Entertainment-Education Messages. Communication Theory, 18(3), 407-425.

Mumby, D. K. (1987). The political function of narrative in organizations. Communication Monographs, 54(2), 113-127.

Murphy, S. T., Frank, L. B., Moran, M. B., \& Patnoe-Woodley, P. (2011). Involved, transported, or emotional? Exploring the determinants of change in knowledge, attitudes, and behavior in entertainment-education. . Journal of Communication 61(3), 407-431.

Murry Jr, J. P., \& Dacin, P. A. (1996). Cognitive moderators of negative-emotion effects: Implications for understanding media context. Journal of Consumer Research, 22(4), 439-447.

Nan, X. (2009). Emotional Responses to Televised PSAs and Their Influence on Persuasion: An Investigation of the Moderating Role of Faith in Intuition. Communication Studies, 60(5), 426-442.

Newbert, S. L. (2008). Value, rareness, competitive advantage, and performance: a conceptual-level empirical investigation of the resource-based view of the firm. Strategic Management Journal, 29(7), 745-768.

Ni, P. (2008). Why vivid storytelling inspires giving [Electronic Version]. Stanford Social Innovation Review, February from http://www.ssireview.org/blog/entry/why_vivid_storytelling_inspires_giving.

Nicholls, A. (2010). The Legitimacy of Social Entrepreneurship: Reflexive Isomorphism in a Pre-Paradigmatic Field. Entrepreneurship Theory and Practice, 34(4), 611633. 
Niles, J. D. (1999). Homo narrans: the poetics and anthropology of oral literature. Philadelphia: Univ of Pennsylvania Pr.

Nisbett, R. E., \& Ross, L. (1980). Human inference: Strategies and shortcomings of social judgment. Englewood Cliffs: Prentice-Hall

Oatley, K. (1994). A taxonomoy of the emotions of literary response and a theory of identification in fictional narrative. Poetics, 23, 53-74.

Oatley, K. (1995). A taxonomy of the emotions of literary response and a theory of identification in fictional narrative. Poetics, 23(1-2), 53-74.

Oatley, K. (1999). Meetings of minds: Dialogue, sympathy, and identification, in reading fiction. Poetics, 26(5-6), 439-454.

Oatley, K. (2002). Emotions and the story worlds of fiction. In M. C. Green, J. J. Strange \& T. C. Brock (Eds.), Narrative Impact: Social and Cognitive Foundations (pp. 39-69). Mahwah: Lawrence Earlbaum Associates.

O'Connor, E. (2002). Storied business: Typology, intertextuality, and traffic in entrepreneurial narrative. Journal of Business Communication, 39(1), 36-54.

Pacini, R., \& Epstein, S. (1999). The relation of rational and experiential information processing styles to personality, basic beliefs, and the ratio-bias phenomenon. Journal of Personality and Social Psychology, 76(6), 972-987.

Paivio, A., Yuille, J. C., \& Madigan, S. A. (1968). Concreteness, imagery, and meaningfulness values for 925 nouns. Journal of Experimental Psychology, 76(1), $1-25$.

Park, O. S., Sims, H. P., \& Motowidlo, S. J. (1986). Affect in organizations: How feelings nad emotions influence managerial judgment. . In H. P. Sims \& D. A. Gioia (Eds.), The thinking organization (pp. 215-237). San Francisco: JosseyBass.

Parker, S. C. (2009). The economics of entrepreneurship. Cambridge: Cambridge University Press.

Pekar, T. (2011). Invite your listener to share the story [Electronic Version]. Stanford Social Innovation Review, May from http://www.ssireview.org/blog/entry/invite_your_listener_to_share_the_story/.

Pence, J. (2004). Narrative Emotion: Feeling, Form and Function. Journal of Narrative 
Theory, 34(3), 273-276.

Pennington, N., \& Hastie, R. (1993). The story model for juror decision making. In R. Hastie (Ed.), Inside the Juror: The Psychology of Juror Decision Making (pp. 192-221). Cambridge: Cambridge University Pres.

Penrose, E. T. (1959). The Theory of the Growth of the Firm. Oxford: Basil Blackwell.

Pentland, B. T. (1999). Building process theory with narrative: From description to explanation. Academy of Management Journal, 24(4), 711-724.

Pentland, B. T., \& Feldman, M. S. (2007). Narrative networks: Patterns of technology and organization. Organization Science, 18(5), 781-795.

Peredo, A. M. A., \& Chrisman, J. J. (2006). Toward a theory of community-based enterprise. Academy of Management Review, 31(2), 309-328.

Pervin, L.A. (Eds). Handbook of Personality: Theory and Research. (pp. 242-262). Guilford Press: New York, NY.

Peteraf, M. A. (1993). The cornerstones of competitive advantage: A resource-based view. Strategic Management Journal, 14(3), 179-191.

Peters, E., \& Slovic, P. (2000). The Springs of Action: Affective and Analytical Information Processing in Choice. Personality and Social Psychology Bulletin, 26(12), 1465-1475.

Peters, E., \& Slovic, P. (2000). The Springs of Action: Affective and Analytical Information Processing in Choice. Personality and Social Psychology Bulletin, 26(12), 1465-1475.

Peterson, J. B. (1999). Maps of meaning: The architecture of belief. New York: Psychology Press.

Pettit, J. D., Goris, J. R., \& Vaught, B. C. (1997). An examination of organizational communication as a moderator of the relationship between job performance and job satisfaction. Journal of Business Communication, 34(1), 81.

Petty, R. E., BriÃ \pm ol, P., \& Tormala, Z. L. (2002). Thought confidence as a determinant of persuasion: The self-validation hypothesis. Journal of Personality and Social Psychology, 82(5), 722-741.

Petty, R. E., \& Cacioppo, J. T. (1986). The elaboration likelihood model of persuasion. In Advances in Experimental Psychology (Vol. 19, pp. 124-192). London: Academic Press Inc. 
Petty, R. E., Cacioppo, J. T., \& Kasmer, J. A. (1988). The role of affect in the elaboration likelihood model of persuasion. In L. Donohew, H. E. Sypher \& E. T. Higgins (Eds.), Communication, social cognition, and affect (pp. 117-146). Hillsdale: Lawrence Erlbaum Associates, Inc.

Pfarrer, M. D., Pollock, T. G., \& Rindova, V. P. (2010). A tale of two assets: The effects of firm reputation and celebrity on earnings surprises and investors' reactions. Academy of Management Journal, 53(5), 1131-1152.

Pfeffer, J. S., \& Salancik, G. R. (1978). The external control of organizations: a resource dependence perspective. New York: Harper \& Row.

Phillips, N., Lawrence, T. B., \& Hardy, C. (2004). Discourse and institutions. Academy of Management Journal, 29(4), 635-652.

Phills, J. A., Deiglmeier, K., \& Miller, D. T. (2008). Rediscovering social innovation. Stanford Social Innovation Review, 6(4), 34-43.

Pinney, T. (1963). Essays of Georges Eliot. New York: Columbia University Press.

Podolny, J. M. \& Page, K. L. (1998). Network forms of organization. Annual Review of Sociology, 24: 57-76.

Polkinghorne, D. (1988). Narrative knowing and the human sciences. Albany: State Univ of New York Press.

Polyorat, K., Alden, D. L., \& Kim, E. S. (2007). Impact of narrative versus factual print ad copy on product evaluation: The mediating role of ad message involvement. Psychology and Marketing, 24(6), 539-554.

Porac, J. F., Mishina, Y., \& Pollock, T. G. (2002). Entrepreneurial narratives and the dominant logics of high growth firms. In A. Huff \& M. Jenkins (Eds.), Mapping Strategic Knowledge (pp. 112-136). Thousand Oaks: Sage.

Porter, M. E. (1998). Competitive strategy: techniques for analyzing industries and competitors: with a new introduction: Free Pr.

Ravasi, D., \& Phillips, N. (2011). Strategies of alignment. Strategic Organization, 9(2), 103.

Reinard, J. C. (1988). The Empirical Study of the Persuasive Effects of Evidence The Status After Fifty Years of Research. Human Communication Research, 15(1), 359. 
Rhodes, C., \& Brown, A. D. (2005). Narrative, organizations and research. International Journal of Management Reviews, 7(3), 167-188.

Richardson, C. (2011). What social enterprises can learn from charities (Publication., from The Guardian: https://socialenterprise.guardian.co.uk/social-enterprisenetwork/2011/feb/03/brand-building-social-enterprise-charities

Ricoeur, P. (1984). The reality of the historical past: Marquette University Press Milwaukee, WI.

Ricoeur, P., \& Thompson, J. B. (1981). Hermeneutics and the human sciences: Essays on language, action, and interpretation. New York: Cambridge Univ Pr.

Riessman, C. K. (1994). Narrative analysis. London: Sage Publ.

Rindova, V. P., Pollack, T. G., Hayward, M. L. A. (2006). Celebrity firms: The social construction of market popularity. Academy of Management Review, 31(1): 50-71.

Rindova, V. P., Williamson, I. O., Petkova, A. P., \& Sever, J. M. (2005). Being good or being known: An empirical examination of the dimensions, antecedents, and consequences of organizational reputation. Academy of Management Journal, 48(6), 1033-1049.

Rispal, M. H., \& Boncler, J. (2010). Social entrepreneurship in France: Organizational and relational issues. In A. Fayolle \& H. Matlay (Eds.), Handbook of Research on Social Entrepreneurship (pp. 109-124). Cheltenham: Edward Elgar.

Robinson, J. (2006). Navigating social and institutional barriers to markets: How social entrepreneurs identify and evaluate opportunities: New York: Palgrave Macmillan.

Rodwell, J. J., Kienzle, R., \& Shadur, M. A. (1998). The relationship among work-related perceptions, employee attitudes, and employee performance: The integral role of communications, Human Resource Management (Vol. 37, pp. 277-293): Wiley Online Library.

Romanelli, E. (1989). Environments and Strategies of Organization Start-Up: Effects on Early Survival. Administrative Science Quarterly, 34(3), 369-387.

Rudd, A. (2009). In Defence of Narrative. European Journal of Philosophy, 17(1), 60-75.

Ruhnka, J. C. \& Young, J. E. (1991). Some hypotheses about risk in venture capital investing. Journal of Business Venturing, 6(2): 115-133 
Rumelt, R. P. (1984). Towards a strategic theory of the firm. In R. B. Lamb (Ed.), Competitive Strategic Management (pp. 556-570). Englewood Cliffs: Prentice Hall.

Russell, J. A. (1980). A circumplex model of affect. Journal of Personality and Social Psychology, 39(6), 1161-1178.

Russell, J. A., \& Carroll, J. M. (1999). On the bipolarity of positive and negative affect. Psychological Bulletin, 125(1), 3-30.

Sachs, J. D. (2009). Common Wealth: Economics for a Crowded Planet. London: Penguin Press.

Sadoski, M., Goetz, E. T., \& Fritz, J. B. (1993). Impact of concreteness on comprehensibility, interest, and memory for text: Implications for dual coding theory and text design. Journal of Educational Psychology, 85(2), 291.

Sample-Ward, A. (2008). Telling stories [Electronic Version]. Stanford Social Innovation Review, April, 1 from http://www.ssireview.org/blog/entry/telling_stories.

Santos, F. M. (2009). A positive theory of social entrepreneurship. INSEAD Working Paper

Santos, F. M., \& Eisenhardt, K. M. (2009). Constructing markets and shaping boundaries: Entrepreneurial power in nascent fields. Academy of Management Journal, 52(4), 643-671.

Schank, R. C., \& Abelson, R. P. (Eds.). (1995). Knowledge and memory: The real story. Hillsdale: Erlbaum.

Schank, R. C., \& Berman, T. R. (2002). The pervasive role of stories in knowledge and action. In (pp. 287-313). Mahwah: Lawrence Erlbaum Associates.

Schiffrin, D. 2003. We knew that's it: Retelling the turning point of a narrative. Discourse Studies, 5(4): 535-561.

Schneider, E. F. (2004). Death with a Story. Human Communication Research, 30(3), 361-375.

Schoonhoven, C. B., \& Romanelli, E. (2001). Emergent themes and the next wave of entrepreneurship research. In C. B. Schoonhoven \& E. Romanelli (Eds.), The Entrepreneurship Dynamic: Origins of Entrepreneurship and the Evolution of Industries (pp. 383-408). Stanford: Stanford Business Books. 
Schoonhoven, C. B., \& Romanelli, E. (2001). The entrepreneurship dynamic: Origins of entrepreneurship and the evolution of industries: Stanford Business Books.

Schumpeter, J. A. (1950). Capitalism, Socialism, and Democracy (3rd ed.). New York: Harper \& Row.

Schwarz, N., \& Bless, H. (1991). Happy and mindless, but sad and smart? The impact of affective states on analytic reasoning. In J. P. Forgas (Ed.), Emotion and Social Judgments (International Series in Experimental Social Psychology) (pp. 55-71). Elmsford: Pergamon Press.

Schweiger, D. M., \& Denisi, A. S. (1991). Communication with employees following a merger: A longitudinal field experiment. 34(1), 110-135.

Scott, M. B., \& Lyman, S. M. (1968). Accounts. American Sociological Review, 33(1), 46-62.

Scott, W. R. (1998). Organizations: Rational, Natural, and Open Systems (4th ed.). Englewood Cliffs: Prentice-Hall.

Sedor, L. M. (2002). An explanation for unintentional optimism in analysts' earnings forecasts. Accounting Review, 77(4), 731-753.

Shah, A. K., \& Oppenheimer, D. M. (2007). Easy does it: The role of fluency in cue weighting. Judgment and Decision Making, 2(6), 371-379.

Shane, S. (2000). Prior knowledge and the discovery of entrepreneurial opportunities. Organization Science, 11(4), 448-469.

Shane, S., \& Stuart, T. (2002). Organizational endowments and the performance of university start-ups. Management Science, 48(1), 154-170.

Shane, S. A. (2003). A general theory of entrepreneurship: The individual-opportunity nexus. Cheltenham: Edward Elgar Pub.

Shane, S. A. (2012). The importance of angel investing in financing the growth of entrepreneurial ventures. Journal of Finance, 2(2): 1-42.

Shaw, E., \& Carter, S. (2007). Social entrepreneurship: Theoretical antecedents and empirical analysis of entrepreneurial processes and outcomes. Journal of Small Business and Enterprise, 14(3), 418-434.

Shaw, G., Brown, R., \& Bromiley, P. (1998). Strategic stories: How 3M is rewriting 
business planning. Harvard Business Review, May-June: 41-50.

Shepherd, D. A. (1999). Venture capitalists' assessment of new venture survival. Management Science, 45: 621-632.

Shipp, A. J., \& Jansen, K. J. (2010). Reinterpreting Time in Fit Theory: Crafting and Recrafting Narratives of Fit in Medias Res. Academy of Management Review, 36(1), 76-101.

Short, J. C., Moss, T. W., \& Lumpkin, G. T. (2009). Research in social entrepreneurship: past contributions and future opportunities. Strategic Entrepreneurship Journal, 3(2), 161-194.

Sine, W. D., Mitsuhashi, H., \& Kirsch, D. A. (2006). Revisiting Burns and Stalker: Formal structure and new venture performance in emerging economic sectors. Academy of Management Journal, 49(1), 121-132.

Singer, J. A. 2004. Narrative identity and meaning making across the adult lifespan: An introduction. Journal of Personality, 72(3), 437-459.

Sirmon, D. G., Gove, S., \& Hitt, M. A. (2008). Resource management in dyadic competitive rivalry: The effects of resource bundling and deployment. Academy of Management Journal, 51(5), 919-935.

Skoldberg, K. (1994). Tales of change: Public administration reform and narrative mode. Organization Science, 5(2), 219-238.

Skoll Foundation. (2011). Storytelling. From http://www.skollfoundation.org/ approach/storytelling/

Slovic, P., Finucane, M., Peters, E., \& MacGregor, D. G. (2002). Rational actors or rational fools: implications of the affect heuristic for behavioral economics. Journal of Socio-Economics, 31(4), 329-342.

Smith, C. (2011a). For social enterprises: How your mission can help your sales [Electronic Version]. Wejungo Network from http://wejungo.wordpress.com/2011/04/25/for-social-enterprises-how-yourmission-can-help-your-sales/.

Smith, C. (2011b). Stories are the way to build a better public image for social enterprises [Electronic Version]. The Guardian from https://socialenterprise.guardian.co.uk/social-enterprisenetwork/2011/jan/20/public-image-and-social-enterprises.

Smith, M., \& Taffler, R. (1995). The incremental effect of narrative accounting 
information in corporate annual reports. Journal of Business Finance and Accounting, 22(8), 1195-1210.

Smith, E. L. (1997). The Hero Journal in Literature: Parables of Poesis. London: University Press of America.

Somers, M. R. 1994. The narrative constitution of identity: A relational and network approach. Theory and Society, 23(5): 605-649.

Sonenshein, S. (2010). We're Changing - Or are We? Untangling the Role of Progressive, Regressive, and Stability Narratives During Strategic Change Implementation. Academy of Management Review, 53(3), 477-512.

Spors, K. (2008, September 12). Social entrepreneurship is hot, but finding funding still a challenge. Wall Street Journal. Retrieved from http//online.wsj.com.

Starkey, K., \& Crane, A. (2003). Toward green narrative: Management and the evolutionary epic. Academy of Management Journal, 28(2), 220-237.

Starr, A. S., \& MacMillan, I. C. (1990). Resource cooptation via social contracting: resource acquisition strategies for new resources. Strategic Management Journal, $11,79-92$.

Staw, B. M., Bell, N. E., \& Clausen, J. A. (1986). The dispositional approach to job attitudes: A lifetime longitudinal test. Administrative Science Quarterly, 31(1), 56-77.

Stevenson, W. B., \& Greenberg, D. N. (1998). The formal analysis of narratives of organizational change. Journal of Management, 24(6), 741-762.

Stewart, D. W. \& Zhao, Q. 2000. Internet marketing, business models, and public policy. Journal of Public Policy \& Marketing, 19(2): 287-296.

Stinchcombe, A. L. (1965). Social structure and organizations. In J. G. March (Ed.), Handbook of Organizations (Vol. 44, pp. 142-193). Chicago: Rand McNally.

Strauss, A., \& Corbin, J. (1998). Basics of qualitative research: Techniques and procedures for developing grounded theory ( 2 nd ed.). Thousand Oaks: Sage.

Stuart, T. E. (2000). Interorganizational alliances and the performance of firms: A study of growth and innovation rates in a high-technology industry, Strategic Management Journal (Vol. 21, pp. 791-811).

Stuart, T. E., Hoang, H., \& Hybels, R. C. (1999). Interorganizational endorsements and 
the performance of entrepreneurial ventures. Administrative Science Quarterly, $44,315-349$

Suchman, M. C. (1995). Managing legitimacy: Strategic and institutional approaches. Academy of Management Review, 30(3), 571-610.

Suddaby, R., \& Greenwood, R. (2005). Rhetorical strategies of legitimacy. Administrative Science Quarterly, 50(1), 35.

Sundin, E., \& Tillmar, M. (2010). The intertwining of social, commercial, and public entrepreneurship. In A. Fayolle \& H. Matlay (Eds.), Handbook of Research on Social Entrepreneurship (pp. 142-156). Cheltenham: Edward Elgar.

Tan, E. S., \& Fasting, B. T. (1996). Emotion and the structure of narrative film: Film as an emotion machine. Hillsdale: Lawrence Erlbaum Associates, Inc.

Tan, E. S.-H. (1995). Film-induced affect as a witness emotion. Poetics, 23(1-2), 7-32.

Tan, W. L., Williams, J., \& Tan, T. M. (2005). Defining the 'social' in 'social entrepreneurship': Altruism and entrepreneurship. International Entrepreneurship and Management Journal, 1(3), 353-365.

Tetlock, P. C., Saar-Tsechansky, M., \& Macskassy, S. (2008). More Than Words: Quantifying Language to Measure Firms' Fundamentals. The Journal of Finance, 63(3), 1437-1467.

Tiedens, L. Z., \& Linton, S. (2001). Judgment under emotional certainty and uncertainty: The effects of specific emotions on information processing. Journal of Personality and Social Psychology, 81(6), 973-988.

Tobin, T., \& Finger, G. (2011). Of narrative and social entrepreneurship: A powerful story [Electronic Version]. Ashoka from http://ashokau.org/of-narrative-andsocial-entrepreneurship-a-powerful-story/.

Tolbert, P. S., \& Zucker, L. G. (1983). Institutional sources of change in the formal structure of organizations: The diffusion of civil service reform, 1880-1935. Administrative Science Quarterly, 28(1), 22-39.

Townsend, D. M., \& Hart, T. A. (2008). Perceived Institutional Ambiguity and the Choice of Organizational Form in Social Entrepreneurial Ventures. Entrepreneurship Theory and Practice, 32(4), 685-700.

Tracey, P., \& Jarvis, O. (2007). Toward a Theory of Social Venture Franchising. Entrepreneurship Theory and Practice, 31(5), 667-685. 
Trexler, J. (2010, April 28). Ditch the pitch? Contests and the search for social venture capital. Change.org. retrieved from http://news.change.org.

Van Maanen, J., \& Schein, E. H. (1979). Toward a theory of organizational socialization. Research in Organizational Behavior, 1(1), 209-264.

Vasi, I. B. (2009). New heroes, old theories? Toward a sociological perspective on social entrepreneurship. In R. Ziegler (Ed.), An introduction to social entrepreneurship: Voices, preconditions, contexts (pp. 155-173). Northampton: Edward Elgar Publishing.

Venkataraman, S. (1997). The distinctive domain of entrepreneurship research. In J. Katz (Ed.), Advances in Entrepreneurship, Firm Emergence, and Growth (Vol. 3, pp. 119-138). Greenwich: JAI Press.

Villanueva, J., Van de Ven, A. H., \& Sapienza, H. J. (2012). Resource mobilization in entrepreneurial firms. Journal of Business Venturing, 27(1), 19-30.

Volery, T., \& Hackl, V. (2011). The promise of social franchising as a model to achieve social goals. In A. Fayolle \& H. Matlay (Eds.), Handbook of Research on Social Entrepreneurship (pp. 157-181). Cheltenham: Edward Elgar.

Wade, S., Alexander, P., Schraw, G., \& Kulikowich, J. (1996). The perils of criticism: Response to Goetz and Sadoski. Reading Research Quarterly, 30, 512-515.

Wallemacq, A., \& Sims, D. (1998). The struggle with sense. In D. Grant, T. Keenoy \& C. Oswich (Eds.), Discourse and Organization (pp. 119-133). London: Sage.

Watson, D., \& Clark, L. A. (1984). Negative affectivity: The disposition to experience aversive emotional states. Psychological Bulletin, 96(3), 465-490.

Weick, K. E. (1979). The social psychology of organizing. Reading: Addison-Wesley.

Weick, K. E. (1995). Sensemaking in organizations (Vol. 3). Thousand Oaks: Sage Publications, Inc.

Weisband, S., \& Atwater, L. (1999). Evaluating self and others in electronic and face-toface groups. Journal of Applied Pscyhology, 84(4), 632-639.

Weisbrod, B. (1977). The voluntary nonprofit sector. Lexington: DC Heath and Co. 
Wentura, D. Rothermund, K. \& Bak, P. (2000). Automatic vigilance: The attentiongrabbing power of approach- and avoidance-related social information. Journal of Personality and Social Psychology, 78(6): 1024-1037.

Wentzel, D., Tomczak, T., \& Herrmann, A. (2010). The moderating effect of manipulative intent and cognitive resources on the evaluation of narrative ads. Psychology and Marketing, 27(5), 510-530.

Wernerfelt, B. (1984). A resource-based view of the firm. Strategic Management Journal, 5(2), 171-180.

Wernerfelt, B. (2011). Invited Editorial: The Use of Resources in Resource Acquisition. Journal of Management, 37(5), 1369-1373.

Wigren, J. (1994). Narrative completion in the treatment of trauma. Psychotherapy: Theory, research, practice, training, 31(3), 415-423.

Wilkins, A. L. (1984). The creation of company cultures: The role of stories and human resource systems. Human Resource Management, 23(1), 41-60.

Wit, J. B. F., Das, E., \& Vet, R. (2008). What works best: Objective statistics or a personal testimonial? An assessment of the persuasive effects of different types of message evidence on risk perception. . Health Psychology, 27, 110-115.

Yekovich, F. R., \& Thorndyke, P. W. (1981). An evaluation of alternative functional models of narrative schemata. Journal of Verbal Learning and Verbal Behavior, 20(4), 454-469.

Yin, R. K. (1984). Case Study Research: Design and Methods. Beverly Hills: Sage Publishing.

Yin, R. K. (2003). Case Study Research (3rd ed.). Thousand Oaks: Sage Inc.

Zadek, S., \& Thake, S. (1997). Send in the social entrepreneurs. New Statesman 26(1), 31. 


\section{VITA}

Philip Thomas Roundy attended Marlington High School, Alliance, Ohio. In 2000 he entered Kent State University in Kent, Ohio. He received a Bachelor of Arts in Economics in May, 2004. In August, 2004 he entered the University of South Florida in Tampa, Florida. He received a Master of Arts in Economics in May, 2007 and a Master of Science in Management and Organization Theory in May, 2008. In August, 2008 he entered the McCombs School of Business at the University of Texas at Austin.

Email: phil.roundy@mccombs.utexas.edu

This manuscript was typed by the author. 